
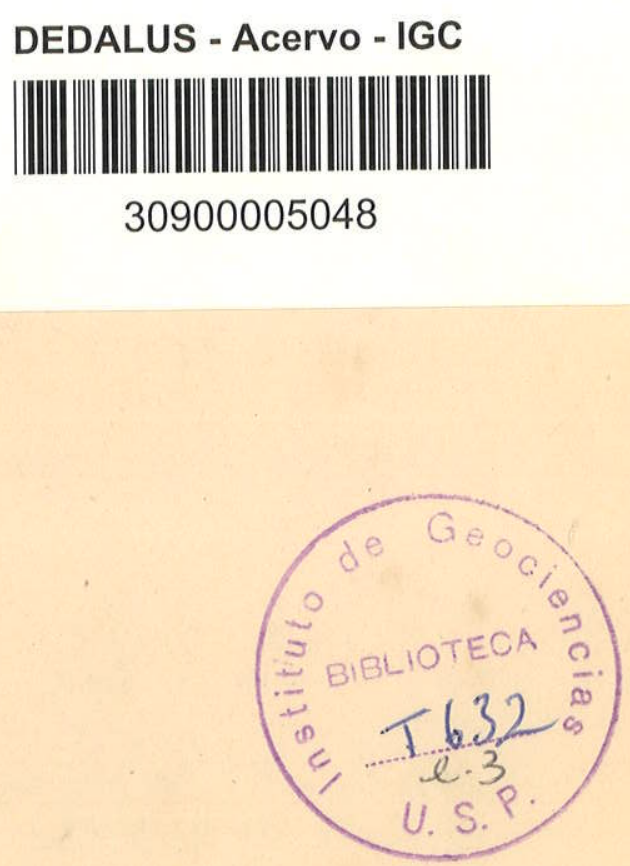

\title{
TECTÔNICA DA ÁREA DAS FOLHAS DE SÃO ROQUE E PILAR DO SUL
}

\section{YOCITERU HASUI}

Tese apresentada ao Concurso de Livre Docência no Departamento de Geologia Geral do Instituto de Geociências da Universidade de São Paulo

1973 


\section{INDICE}

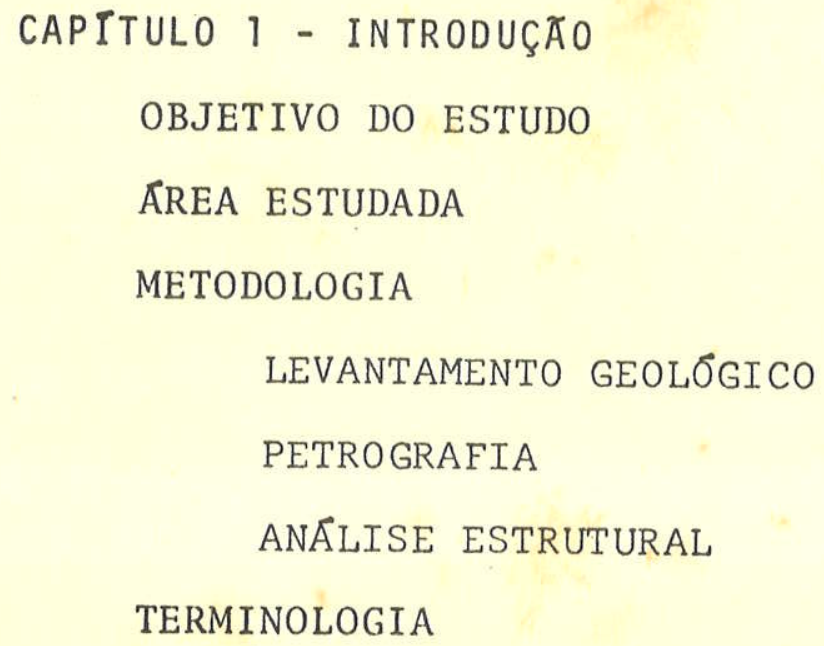

CAPITULO 4 - ANÁLISE DA LITOLOGIA

METAPELITOS

METAPSAMITOS

ROCHAS CALCÅRIAS E CALCO-SILICATADAS

METABASITOS

ROCHAS GRANITÓIDES

BLOCO ITUPARANGA

BLOCO COTIA

ECTINITOS 
MIGMATITOS

Paleos soma

Neos soma

ROCHAS GRANITOIIDES

Complexo Piedade

Outros Corpos

BLOCO JUQUITIBA

MIGMATITOS ESTROMATITICOS

Paleos soma

Quartzitos

Metabasitos

MIGMATITOS OFTALMITICOS

ROCHAS GRANITOIDES

BACIA DO PARANÁ

MAGMÃTICAS MESOZOICAS

SEDIMENTOS TERCIARIOS E QUATERNARTIOS

CAPITULO 5 - ANALISE DO MAGMATISMO

CAPITULO 6 - ANÁLISE DO METAMORFISMO

BLOCO SÃO ROQUE

BLOCO ITUPARANGA

BLOCO COTIA

BLOCO JUQUITIBA

SERIE FACIAL

METAMORFISMO CATACLÁSTICO OU DINÂMICO 
CAPITULO 7 - ANALISE DA ESTRATIGRAFIA

TRIPARTIÇÃO DO PRE-CAMBRIANO 96

SUBDIVISÕES DO GRUPO AÇUNGUI 100

AMBIENTE DE SEDIMENTAÇÃO

CAPITULO 8 - ANALLISE DAS ESTRUTURAS

ESTRUTURAS RELIQUIARES

105

ESTRUTURAS TECTOGENAS 106

FALHAS

106

JUNTAS

110

XISTOSIDADE

117

FOLIAÇÃO DE CRENULAÇÃO

131

LINEAÇÕES

136

DOBRAS

QUALIFICAÇÃO DOS SISTEMAS DE JUNTAS 153

ESTRUTURAS INTERNAS DOS CORPOS GRANITOIDES 155 REGIONALIZAÇÃO DOS DADOS ESTATISTICOS

ANÁLISE DO DOBRAMENTO

BLOCOS SÃO ROQUE E ITUPARANGA

BLOCOS COTIA E JUQUITIBA

CORRELAÇÃO DAS FASES DE DOBRAMENTO

CAPITULO 10 - EVOLUÇÃO TECTÕNICA DA AREA DAS FOLHAS DE PILAR DO SUL E DE SÃO ROQUE 
BIBLIOGRAFIA

ILUSTRAÇOES INSERIDAS NO TEXTO

33 Figuras numeradas de 1 a 33

16 Tabelas numeradas de 1 a 16

19 Fotos numerados de 1 a 19

34 Fotomicrografias numeradas de 1 a 34

\section{ANEXOS}

Folhas geolōgicas de São Roque e de

Pilar do Sul em escala de 1:100.000 


\title{
CAPITULO 1 - INTRODUÇÃO
}

\author{
OBJETIVO DO ESTUDO
}

Na última década, numerosos trabalhos foram divulga dos, versando sobre o Pré-Cambriano dos Estados de São Paulo e Paraná. Em nosso Estado, os estudos se concentraram nos arredores e a oeste da Capital, no vale do Ribeira e na re gião de Amparo-Pinhal.

As tentativas de regionalização dos dados têm trope çado com alguns problemas e, dentre eles, dois se apresentam como cruciais, quais sejam:

1 - a relação entre os Grupos São Roque e Açungui, e

2 - a relação entre os epimetamorfitos desses dois grupos com o chamado Complexo Migmatítico ou Cristalino ou Brasileiro, no qual são colocadas as rochas migmatiticas e gnáissicas em geral.

A solução, obviamente, exige de início o levantamen to geológico daquelas entidades. Contudo, o mapeamento no Estado de São Paulo vem sendo executado paulatinamente, re querendo ainda alguns anos para se completar e, nessas ci cunstâncias, de momento só podemos focalizar aqueles proble mas em äreas limitadas onde as três entidades comparecem. Uma área desse tipo foi escolhida, mapeada e estudada em escala de semi-detalhe, e a análise das unidades litológicas, do me tamorfismo, do magmatismo, das estruturas, da geocronologia e da estratigrafia é apresentada na primeira parte do texto.

0 conjunto dos dados apresentados possibilita estabe lecer uma sucessão de eventos tectônicos, que permite compre ender a evolução da área, em termos gerais, e as relações en tre aquelas três entidades. Essa síntese elegemos como obje 
tivo precípuo deste trabalho e é apresentada na última parte do texto.

\section{ĀREA ESTUDADA}

A área objeto deste trabalho está compreendida entre os paralelos de $23^{\circ} 30^{\prime}$ e $24^{\circ} 00^{\prime}$ de latitude sul e os meridia nos de $47^{\circ} 00^{\prime}$ e $48^{\circ} 00^{\prime}$ de longitude oeste de Greenwich.

Totaliza ela $5644 \mathrm{~km}^{2}$, dos quais $1982 \mathrm{~km}^{2}(35,1 \%)$ dizem respeito a unidades estratigráficas da Bacia do Paraná. Nos restantes $3662 \mathrm{~km}^{2}$ acham-se expostas rochas mais anti gas, cobertas aqui e ali por delgadas e restritas películas sedimentares cenozóicas. Tais rochas mais antigas têm sido incluídas nos Grupos São Roque e Açungui e no Complexo Cris talino.

A área estudada corresponde às Folhas de São Roque e Pilar do Sul, de $30^{\prime} \times 30^{\prime}$, cujos indices de nomenclatura são respectivamente SF.23-Y-C-V e SF.23-Y-C-IV. Elas foram ma peadas geologicamente em escala $1: 100.000$, sendo apresenta das em anexo,em escala de $1: 176.000$.

Essas folhas, conforme indica a Figura 1 , constituem um elo de ligação parcial entre as áreas recentemente estuda das nos arredores e a oeste da cidade de são Paulo com aque la do Projeto Ribeira.

\section{METODOLOGIA}

\section{LEVANTAMENTO GEOLŐGICO}

As plantas-base foram preparadas aproveitando todos os elementos cartográficos disponíveis, quais sejam:

1 - as fotos aéreas e fotomosaicos em 1:25.000 da Aerofoto Natividade Ltda., executados para o Instituto Agro nômico de Campinas em 1962. Os fotomosaicos são os de núme ros R-1 a R-16 e S-1 a S-16, todos da Região 7; . 


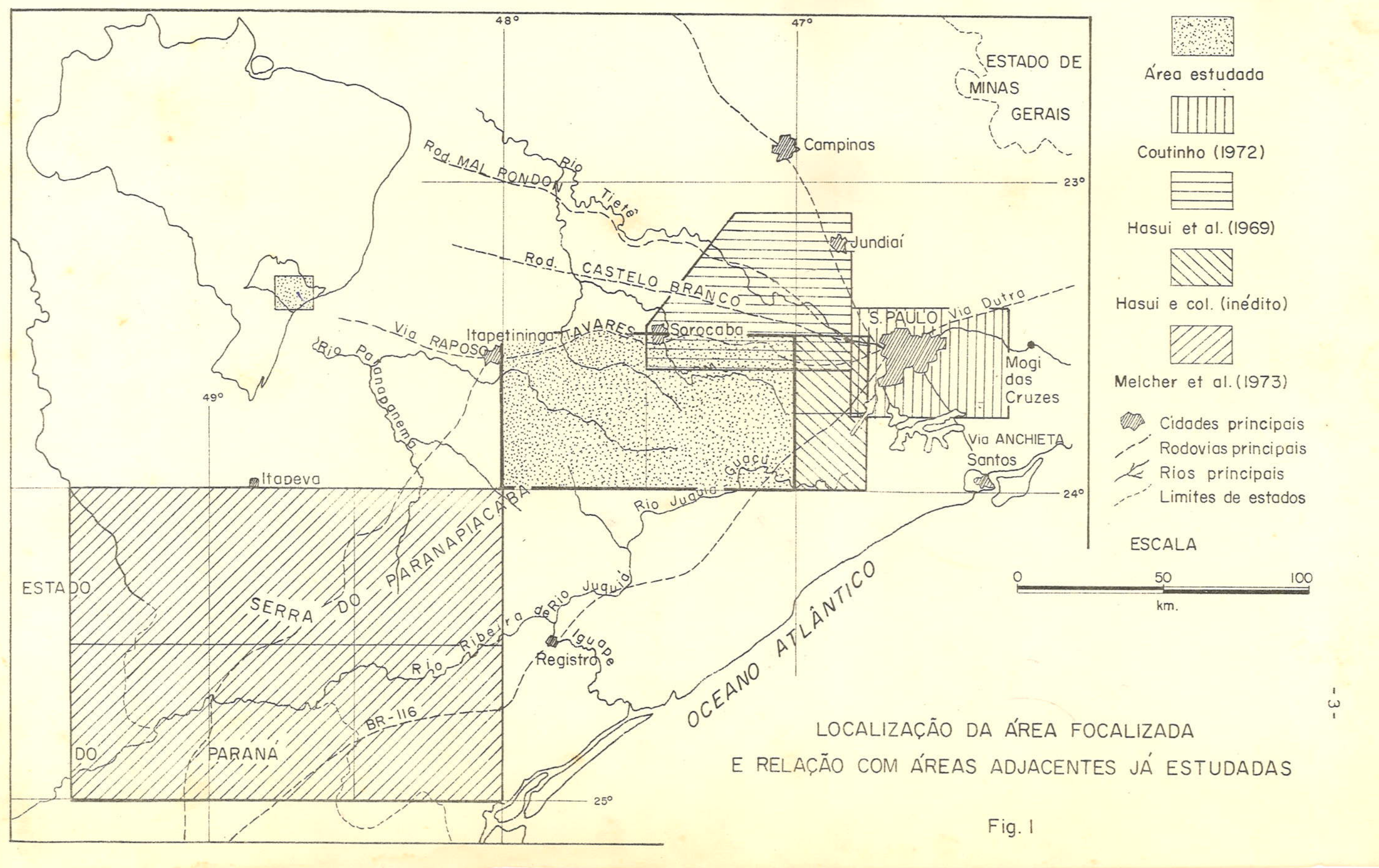


2 - mapas editados pelo Instituto Geográfico e Geoló gico do Estado de São Paulo em 1:250.000 (Folha de São Paulo, 1954), 1:100.000 (Folha de Piedade, 1927) e 1:50.000 (Folha de São Miguel Arcanjo, 1970; Folha de Juquitiba, 1971):

3 - mapas municipais elaborados pelo Instituto Brasi leiro de Geografia e Estatistica em escalas 1:50.000, 1:75.000 e 1:100.000, cobrindo os municípios da área de inte resse;

4 - mapa 01-101 do Grupo Executivo do Grande São Pau 10 (GEGRAN) em 1:100.000, 1967;

5 - Folhas de São Roque e Pilar do Sul em 1:100.000, preparadas pela PROTEC - Projetos Técnicos e Obras de Enge nharia Ltda.

As observações de campo foram feitas ao longo de es tradas carroçáveis, preferencialmente as transversais às es truturas, e em caminhamentos quando necessários, demandando 80 dias üteis.

Procuramos, dentro dos limites das possibilidades de tempo, acesso e de interesse, adotar espaçamentos os mais apertados. Não foi possível uniformizá-los, já que na parte sul da área elevam-se os contrafortes da Serra de Paranapia caba, onde as vias de acésso existem em baixa densidade. As estradas constantes dos mapas geológicos anexos foram todas percorridas.

As observações de campo visaram definir os tipos li tológicos, seus limites, relações espaciais e suas estrutü ras, bem como coletar amostras para estudos de laboratório. As observações foram realizadas de modo a integrar seções geo lógicas, em vez de se limitarem a pontos para posterior inte gração.

Exposições de rochas sãs ou apenas ligeiramente in temperizadas são comuns, mas parte das observações foram fei tas em solos estruturados. Nas áreas de rochas graníticas 
ou granitóides aparecem matacões em profusão e, vez ou outra, lagedos com várias centenas de metros quadrados. Nas re giões de rochas metamórficas, são nos cortes de estradas e leitos de cursos d'água que se observam rochas sãs ou semi-decompostas, mas em geral a alteração é profunda, obrigando à observação de solos estruturados. Várias pedreiras exis tem e nelas são possiveis exames mais completos das rochas.

Os dados geológicos foram no campo lançados em foto mosaicos. O mapeamento geológico implica necessariamente em extrapolações e a utilização de fotomosaicos no campo minimi za a subjetividade dessas extrapolações, face aos critérios correntes de fotointerpretação. Complementando com observa ções de fotos aéreas, os dados foram transportados para as plantas-base.

Os contatos de litologias diferentes foram qualifica dos nos mapas geológicos anexos como "observado", quando vís to no campo ou extrapolado com alto grau de certeza, e "pro vável", quando sua existência é certa mas sua localização en volve dificuldades.

As atitudes dos elementos estruturais que figuram nos mapas geológicos anexos visam apenas indicar as atitudes gerais no ponto e na área em seus arredores. Evitamos lan çar todas as medidas feitas, que se elevam a milhares,porque haveria sobrecarga desnecessäria do desenho, sem retratar perfeitamente as estruturas observadas, que obedecem a pa drões complexos, como veremos. Julgamos que melhor seria mostrar as tendências direcionais através de lineamentos, os quais ressaltam nitidamente nas fotos aéreas. Assim, a par tir de fotos aéreas e fotomosaicos foram traçados os linea mentos e as observações de campo e a análise estrutural mos traram ser de dois tipos: um correspondente a sistemas de juntas subverticais ou verticais e o outro, a xistosidade, es tratificação reliquiar, bandeamento, planos axiais de dobras e eixos de dobras. Em corpos magmáticos, os dois tipos tam 
bém estão presentes: um correspondendo a juntas e outro, à fo liação. Os dois conjuntos de lineamentos foram discrimina dos nos mapas anexos e serão objeto de análise detalhada mais adiante.

Os símbolos usados procuraram obedecer à padroniza ção sugerida pelo Departamento Nacional da Produção Mineral (Manual de Normas Tẻcnicas).

\section{PETROGRAFIA}

Duzentas e setenta e quatro amostras foram colhidas e estudadas em seções delgadas para exame petrográfico.

0 estudo foi feito segundo as técnicas convencionais, em microscópio polarizador Leitz, modelo Dialux-pol. As des crições de mineralogia, texturas e estruturas limitaram-se a um nivel compativel com o caráter de semi-detalhe do presen te estudo, suficiente para caracterizar e diferenciar as uni dades litológicas.

Em amostras julgadas representativas de algumas lito logias ou variações litológicas foram executadas análises mo dais pelo método de Chayes (1949), com malhas adequadas à granulação $(0,1$ a $0,3 \mathrm{~mm})$ e nümero de pontos contados nunca inferior a 1000 . Os resultados são expressos em porcenta gens de volume.

As determinações mineralógicas se basearam sobretudo em Heinrich (1956) e a terminologia petrogräfica se baseiam em Williams et al. (1954) e Winkler (1967).

\section{ANĀLISE ESTRUTURAL}

A análise estrutural foi conduzida em níveis mesoscó pico e microscópico, segundo os métodos modernos descritos por Whitten (1966) e Turner $e$ Weiss (1963). 
Em nível mesoscópico, foram estabelecidas algumas áreas (domínios ou subpopulações) estatisticamente homogê neas, a partir dos mapas de lineamentos fotogeológicos. Em tais áreas observamos as estruturas, que são apresentadas em diagramas $\pi$ (projeções de polos) e em diagramss de eixos $B$ ou b (eixos reais ou lineações paralelas a eles). A rigor, tais domínios são aproximadamente homogêneos, pois há seme lhança de orientações e não identidade, mas esse fato não prejudica o método (Whitten, 1966).

Essa análise mesoscópica conduziu a resultados que foram testados em toda a área e se mostraram consistentes,pos sibilitando generalizações.

No tocante à análise microscópica, ela se limitou a aspectos qualitativos, observados em seções delgadas e poli das. Face à preocupação em se definir nesta instância os traços gerais da evolução tectônica, postergamos a aplicação de técnicas quantitativas para oportunj.dade futura.

\section{TERMINOLOG IA}

Qualquer sistema de classificação ou nomenclatura de feições ou fenômenos pode ser questionado por sua maior ou menor adequação ou pelo seu caráter mais ou menos natural. Não há dúvida, porém, que a sistematização é fundamental,pois nos permite registrar, agrupar e correlacionar os fatos ob servados.

E, pois, desejável que os termos de uso controverti do sejam devidamente definidos ao serem usados, pois em vez de esclarecer podem introduzir confusões na compreensão de inúmeros aspectos petrológicos, geológicos, estruturais e tectônicos.

Por isso, no texto que se segue procuraremos definir ou indicar o autor da definição ou conceito, sempre que fo rom usados termos de significado controverso. 


\section{CAPITULO 2 - ESTUDOS GEOLŌGICOS ANTERIORES}

Alguns trabalhos foram já publicados, abordando as pectos particulares da área, como os de Coutinho (1953) sobre a petrologia da região de São Roque, de Franco (1958) a res peito de rochas termometamórficas, de Hennies et al. (1967) abordando os grandes falhamentos transcorrentes, de Felicis simo Jr. (1968) sobre as rochas alcalinas do vale do rio sa rapuí e o de Bettencourt (1971) descrevendo as rochas calcá rias da região de Votorantim.

Abordagens regionais aparecem nos estudos de Hasui et al. (1969) incluindo a quarta parte setentrional da Folha de São Roque e o canto nordeste da Folha de Pilar do Sul, de A Imeida (1964) caracterizando a geomorfologia da região e de Moraes Rego (1933), descrevendo a litologia do pré-devoniano paulista.

Sobre áreas adjacentes ou correlatas existem vários estudos divulgados, destacando-se os de Coutinho (1972) sobre a regiäo de São Paulo, de Melfi et al. (1965), Petri e Suguio (1969) e Melcher et al. (1973) sobre a região do vale do rio Ribeira de Iguape, de Marini et al. (1967), Fuck et al. (1967) e Fuck et al. (1971), sobre o leste paranaense. Abordam eles aspectos regionais dos Grupos Açungui e São Roque, bem como dos gnaisses e migmatitos dos Estados de São Paulo e do Para ná.

Quanto a mapeamentos geológicos pertinentes à área em foco, bem pouco se fez até o presente. O Mapa Geológico do Estado de São Paulo, editado pelo Instituto Geográfico e Geológico, em 1963, na escala de 1:1.000.000, mostra esquema ticamente a distribuição dos tipos litológicos principais. Hasui et al. (1969) apresentaram um mapa geológico em 1:100.000, que se superpõe parcialmente com as folhas ora apresentadas; esse trecho de superposição foi agora remapea 
do. Mapas de detalhe em áreas restritas existem, como o de Bettencourt (1971), em 1:25.000, referente à região das ro chas calcárias de Votorantim, o de J.S. Bettencourt (inédito), em 1:25.000, referente a rochas análogas na região de Salto de Pirapora,e o de Coutinho (1953) , abrangendo a área São Ro que-Mairinque-Canguera.

A Figura 2 mostra as áreas cobertas por esses mapea mentos anteriores. 


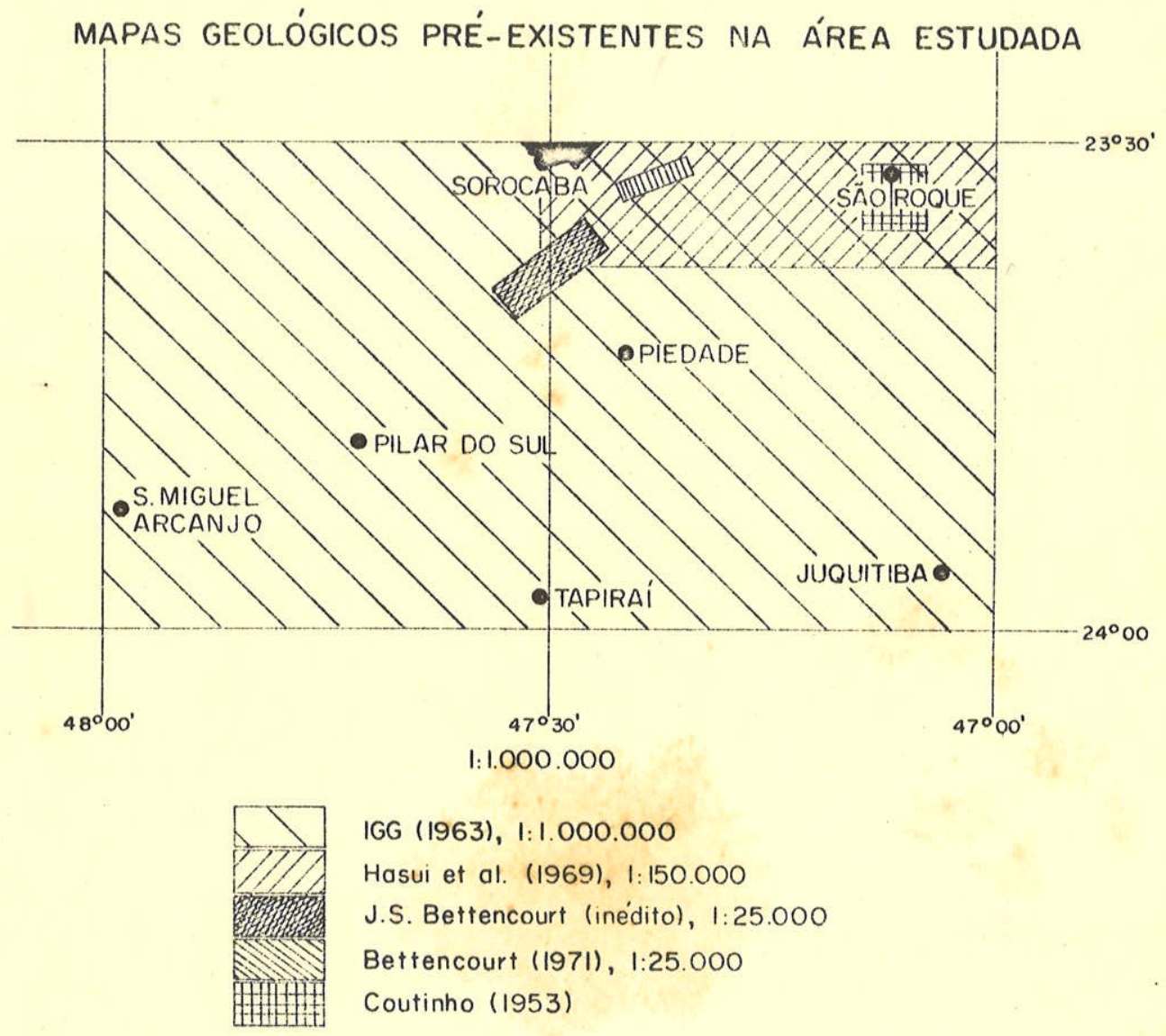

Fig. 2 


\section{CAPITULO 3 - COMPARTIMENTAÇÃO TECTÔNICA DA ĀREA}

Examinando-se as folhas geológicas anexas, nota-se que duas unidades maiores se destacam:

1 - um conjunto heterogêneo de rochas metamörficas dobradas, com corpos granitóides intrusivos, cobrindo prati camente toda a Folha de São Roque e 30\% da área da Folha de Pilar do sul. Em detalhe, notamos que aqui e ali aperecem películas restritas de sedimentos cenozáicos, bem como uma pequena intrusão alcalina no vale do rio Sarapuí, a SSW de Piedade;

2 - um conjunto de rochas sedimentares, quase hori zontais, repousando em discordância angular sobre o embasa mento constituído pelas rochas acima citadas. Este conjunto cobre $70 \%$ da área da Folha de Pilar do Sul e o canto noroes te da Folha de São Roque.

No primeiro conjunto salientam-se três enormes zonas de falhamento, quase retilíneas, denominadas Taxaquara, Pira pora e Caucaia. As duas primeiras foram descritas por Hennies et ar. (1967).

Tais falhamentos, como indica a Figura 3, separam quatro blocos, a que chamaremos de norte para sul, São Roque, Ituparanga, Cotia e Juquitiba. O primeiro e terceiro nomes foram introduzidos por Hasui et al. (1969); de acordo com eles, o Bloco São Roque se estenderia a norte do Falhamento de Taxaquara, mas, nesta instância, preferimos isolar a cunha entre esse falhamento e o de Pirapora sob o nome de Bloco Ituparanga, por exibir características litológicas e estrutu rais próprias, como veremos.

Nas análises que faremos a seguir, procuraremos na medida do possível ordená-las segundo essa compartimentação. As unidades mais jovens serão objeto de rápida descrição, na proporção em que importam para compreendermos a evolução tẹ tônica da área. 
FIGURA 3

COMPARTIMENTAÇÃO TECTÔNICA DA ÁREA

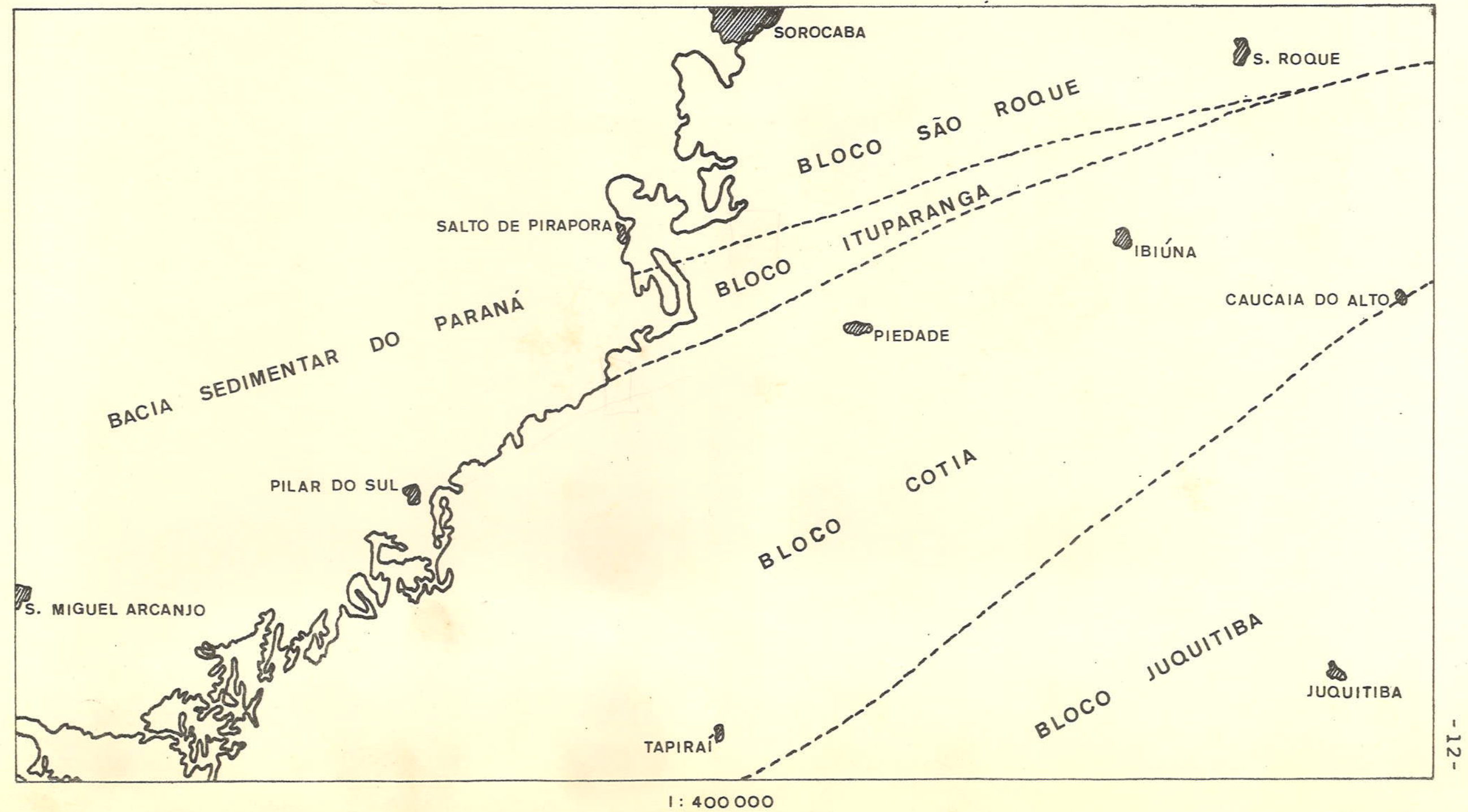




\title{
CAPITULO 4 - ANĀLISE DA LITOLOGIA
}

\author{
BLOCO SÃO ROQUE
}

O Bloco São Roque é constituído por metamorfitos e ro chas granitóides. Os primeiros podemos, para efeito de des crição, grupar em metapelitos, metapsamitos, rochas calcárias e calco-silicatadas e metabasitos.

\section{METAPELITOS}

Dentre os metamorfitos, os filitos são, de longe, as rochas predominantes. Têm cores cinza clara a preta,adquirin do com o intemperismo, tonalidades avermelhadas e amarronza das. Possuem granulação fina e xistosidade conspícua, que lhes confere uma fissilidade em planos paralelos caracteriza dos pelo brilho sedoso.

Os filitos se compõem essencialmente de moscovita (se ricital e quartzo. O quartzo constitui grãos xenoblásticos, achatados e em agregados lenticulares orientados segundo a xistosidade; vez ou outra, são mais ou menos equidimensionais. Exibem sempre extinção ondulante sob nícois cruzados. A mica forma plaquetas em arranjo planar, sendo a principal responsá vel pela xistosidade da rocha.

A proporção desses dois componentes varia muito, pas sando-se de situações com absoluto predomínio de mica a ter mos mais quartzosos, qualificáveis como quartzo-filitos.

Dos acessórios o mais importante é a grafita, finamen te granulada, pigmentando a rocha. O seu teor é determinante da cor, passando-se a tons escuros quando a proporção assume valores de alguns porcentos. Outros acessórios, em grãos mi núsculos e ocasionais são apatita, zircão, turmalina e mine 
ral opaco, com formas arredondadas e subarredondadas. Albita, com geminação polissintética incipiente, é vista raramente. Tais rochas são encontradas a norte de Pantojo-Piragibu-Inhaí ba, bem como na faixa entre os maciços graníticos de soroca ba e de São Francisco.

Filitos e quartzo-filitos aparecem em camadas e lâmi nas paralelas e alternadas; esse mesmo tipo de sucessão é visto também entre filito ou quartzo-filito cinzento e fili to negro. As camadas chegam a ter espessura de até dois de címetros. Chamaremos tais sucessões de ritmitos (Foto l).

Hasui et al. (1969) noticiaram que os filitos do Blo co São Roque, nas adjacências de corpos intrusivos ganham clorita e, em posições proximais, passam a xistos finos, por tando clorita, biotita e moscovita. Essa relação se verifi ca na área em foco, nas bordas dos maciços de sorocaba e de São Francisco indicados na Figura 4. Realmente, a faixa de metapelitos adjacente aos dois maciços, desde salto de Pira pora até a região de Inhaiba, e as suas bifurcações, um ramo para noroeste de Inhaiba, bordejando o Maciço de Sorocaba, e outro ramo a sul da linha Inhaíba-Piragibu-Pantojo,contornan do o Maciço de São Francisco, exibem clorita e ao se aproxi mar dos corpos graníticos, desenvolvem-se biotita e moscovi ta, ao mesmo tempo em que a granulação da rocha aumenta, pas sando-se a micaxistos finos. As três micas se apresentam em combinações e proporções variadas, justificando adjetivações diversas aos xistos.

Esses xistos possuem xistosidade bem desenvolvida $e$, além das micas, têm quartzo na composição. Este exibe extin ção ondulante ao microscópio e normalmente possui forma acha tada e orientação segundo a xistosidade. Quantitativamente. comparece em teores variäveis, chegando-se a quartzo-micaxis tos.

A alternância de leitos e lâminas mais e menos micá ceas é observada também nos micaxistos. 

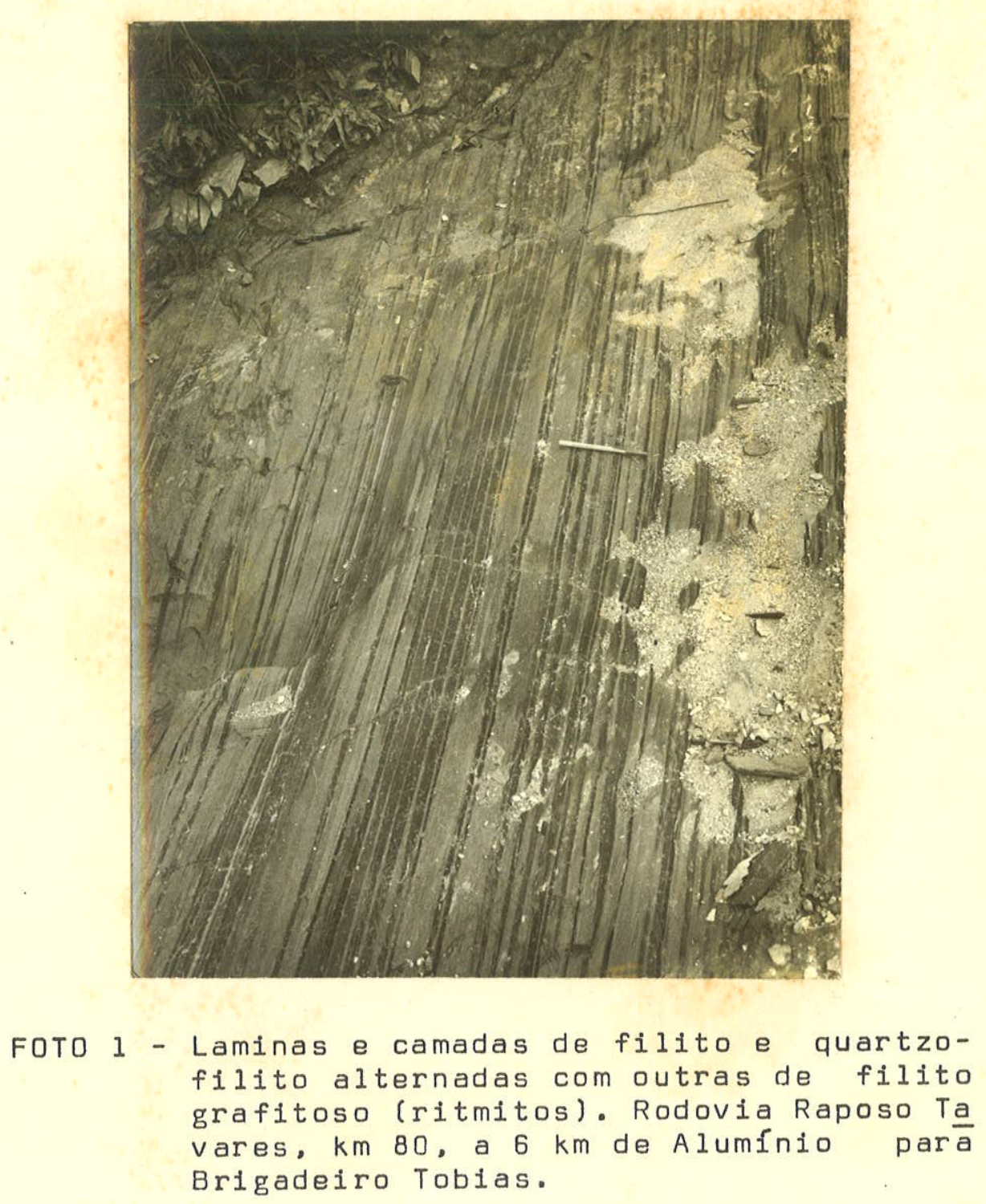
Fig. 4- GRUPOS MAGMÁTICOS NA ÁREA

a MAGMÁTITOS MESOZÓICOS

$X$ GRANITOS PÓS-TECTÔNICOS

1 - Maciço de Pilar do Sul

2- Maciço da Serra do Lopes

3-Maciço do Turvo

+ GRANITÓIDES SINTECTÔNICOS

1 - Maciço Sorocaba

2-Maciço de São Francisco

3 -Maciço das Lavras

4-Maciço de Pirapora

5-Maciço da Represa

6-Complexo de Piedade

7 -Maciço de Jarapurá

8 -Maciço de Caucaio

9 -Maciço de São Sebastião

10 -Maciço das Laranjeiras

II -Maciço da Faz. Dulviro

12 -Maciço do Fumaça

I3-Maciço da Faz. Carioca

$\beta$ METABASITOS

ESCALA - 1:400.000

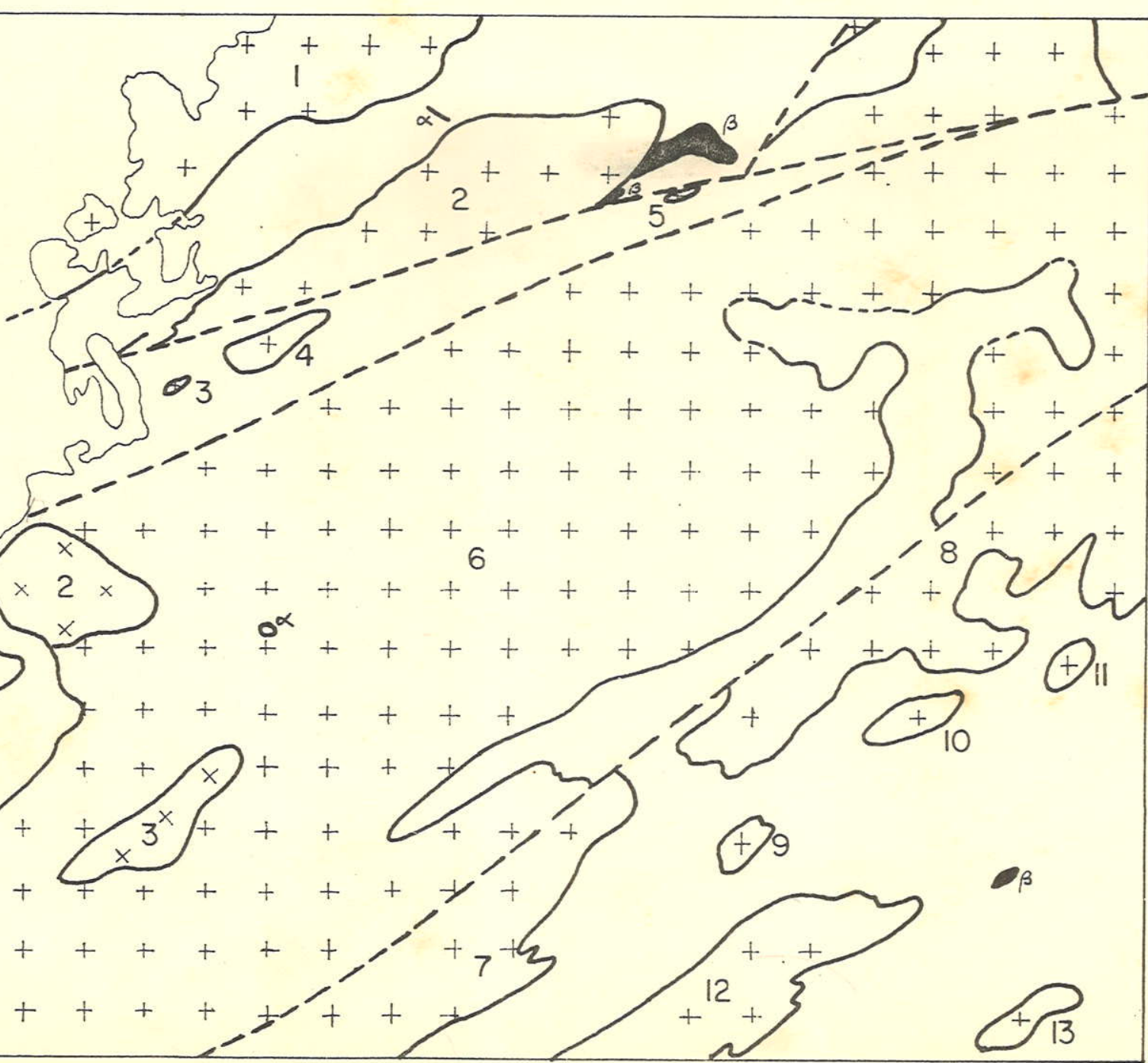


No canto nordeste da Folha de Säo Roque, aparecem fí litos e quartzo-filitos petrograficamente análogos aos des critos, adjacentes ao Falhamento de Taxaquara. Para norte, eles graduam para micaxistos de granulações finas a/ou médias, constituídos essencialmente de quartzo, moscovita e biotita, em proporções variadas. Os acessórios são: granada, mineral opaco e titanita, em grãos pequenos e subëdricos. Zircão comparece em minúsculos cristais inclusos na biotita, geran do halos pleocróicos. Oligoclásio aparece eventualmente nes ses xistos, assim como hornblenda. Ocasionalmente, há fai xas de xistos em que os acessórios importantes são tremoli ta-actinolita, minerais do grupo do epídoto, carbonato e ti tanita, sugerindo origem de sedimento calcärio.

Todos os xistos e filitos descritos apresentam turma lina, apatita e pirita em forma de microporfiroblastos, eué dricos e subédricos, às vezes poiquiloblásticos com inclu sões de quartzo e micas. Geralmente tais minerais se concen tram em fajxas mais micáceas, mas não exibem orientação pré ferencial. Uma parte dos cristais se dispõem segundo a xis tosidade, traduzindo a maior facilidade de desenvolvimento ao longo dessa anisotropia.

Além desses minerais, normalmente os xistos têm por firoblastos ou microporfiroblastos de moscovita, que em par te truncam a xistosidade da matriz e em parte desviam-na, fa zendo-a ondular-se. Com frequencia são poiquiloblásticos, con tendo inclusões de quartzo. No tocante à orientação desses cristais, as mesmas observações acima se verificam.

Tais minerais atestam uma ação pneumatolítica e metas somática relacionada com os corpos granitóides adjacentes. $\bar{A}$ blastese só não se verifica na borda oeste do batólito de São Roque, onde o falhamento transcorrente de são Roque (Ha sui et al., 1969) separa as rochas granitóides dos metapeli tos.

Ocasionalmente, junto aos corpos graníticos, apare 
cem biotita e/ou moscovita-hornfels, constituídos quase que totalmente de micas sem orientação preferencial.

Gnaisses só foram encontrados no canto noroeste da Folha de São Roque, restritos às proximidades dos batólitos de São Roque e do Itaqui (este se desenvolve a leste daquele; Hasui et al., 1969). Esses gnaisses são de granulação média a fina, porfiroblásticos e microporfiroblästicos. A matriz é idèntica aos xistos retro-descritos; os porfiroblastos e microporfiroblastos são de plagioclásio e, em menor propor ção, de microclíneo pertítico, euédricos ou subédricos. o mi croclíneo tem geminação em grade e também de Carlsbad. plagioclásio tem geminações das leis da Albita, Albita-periclíneo e Albita-Carlsbad; exibe zoneamento conspícuo, oscila tório em casos de 3 a 5 zonas concêntricas, ou inverso em ca sos de duas zonas, mas dentro dos limites albita-oligoclásio sódico.

Esses fenoblastos cresceram em parte truncando a xis tosidade da matriz, em parte afastando-a para os lados. São normalmente pojquiloblásticos, contendo inclusões de quartzo e micas. Frequentemente são alongados, mas não têm orienta ção preferencial. Não exibem indícios de deformação ou cata clase. Tais características, em adição ao jazimento adjacen te a corpo granitóide, sugerem origem por feldspatização dos xistos.

Nesses gnaisses também se desenvolveram turmalina, apatita e pirita.

Nos metapelitos que descrevemos, vez ou outra apare cem veios de quartzo concordantes ou discordantes com a xis tosidade e com a estratificação reliquiar.

\section{METAPSAMITOS}

Os quartzitos constituem lâminas e camadas, com es pessuras até métricas, alternando-se com rochas metapelíti 
cas. Ora temos lâminas em sequência rítmica, ora são cama das quartziticas e làminas ou camadas metapelíticas que se al ternam (Foto 2). Faixas há em que se observa um predomínio flagrante de quartzitos, com larguras de centenas de metros e extensão de alguns quilômetros; elas foram assinaladas nos mapas geológicos anexos.

Os quartzitos são rochas brancas a cinzentas, de gra nulação fina. Constituem-se essencialmente de quartzo, ora em grãos mais ou menos eqüidimensionais, configurando textu ra granoblástica, ora mais ou menos achatados, desenvolvendo uma xistosidade pouco conspícua. Os grãos exibem extinção ondulante sob nícois cruzados e o grau de engranzamento é normalmente baixo, justificando às vezes o uso do termo meta-arenito, face à textura blastopsamítica.

Pequenas quantidades de microclíneo pertitico, mine rais opacos, apatita, turmalina, zircão e albita são normal mente observadas. Todavia, moscovita (sericita) é o acessó rio mais importante, às vezes em quantidades suficientes pa ra se qualificar a rocha como quartzo-filito.

Ao se aproximar dos corpos graniticos, os quartzitos ostentam clorita, moscovita e biotita, dispostas orientada mente, bem como apatita, turmalina e pirita, estes minerais em grãos euédricos e subédricos, sem orientação preferencial.

Na região de Votorantim, camadas de quartzito têm quantidades de feldspatos significativas, merecendo designa ções de quartzito feldspático e metarcóseos. Os feldspatos são microclíneo pertítico e oligoclásio. Eles estão serici tizados; o plagioclásio às vezes exibe saussuritização.

Veios de quartzo são vistos ocasionalmente cortando os quartzitos, concordante ou discordantemente com a estrati ficação reliquiar. 


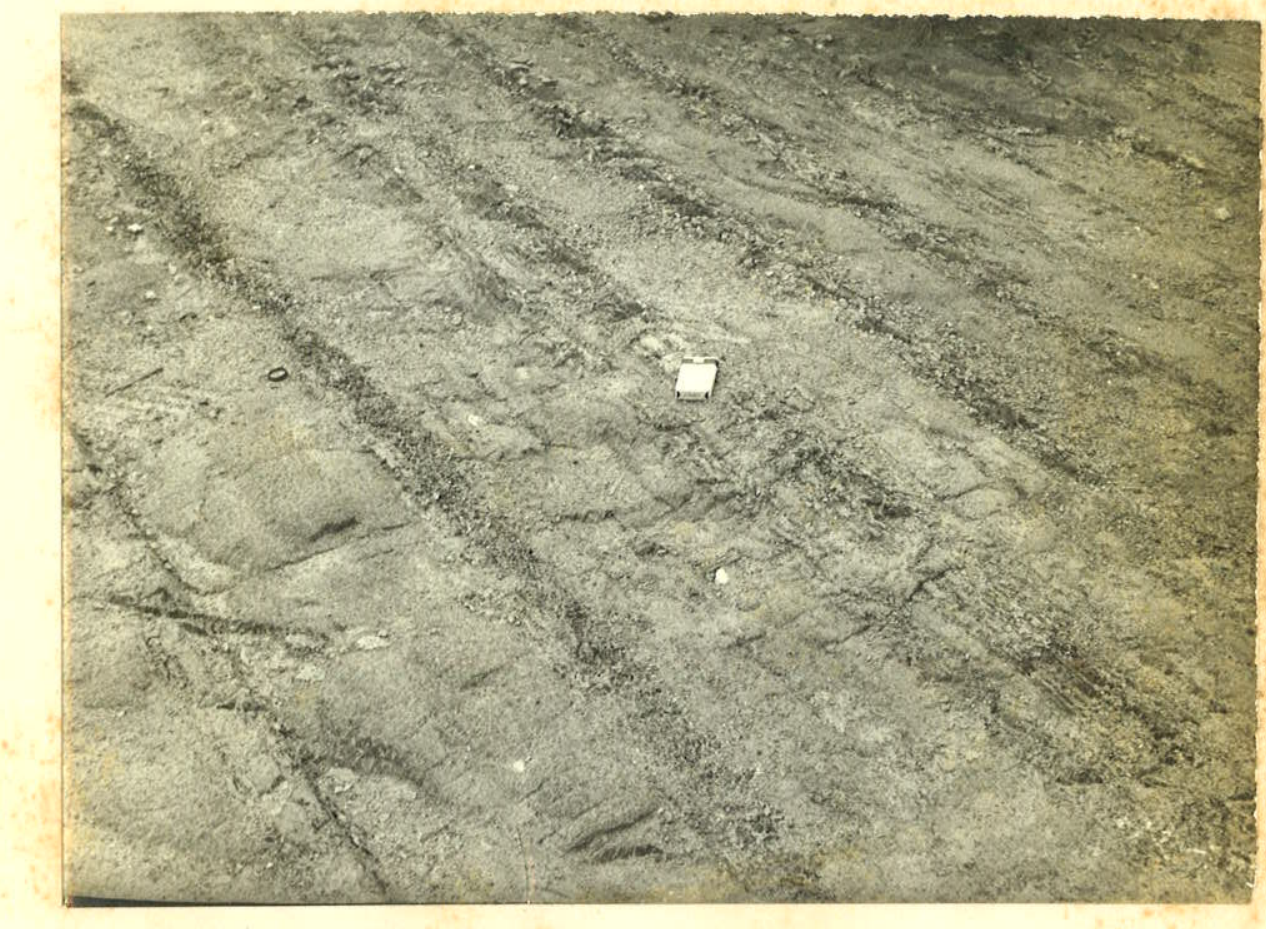

FOTO 2 - Quartzitos e xistos finos em camadas alternadas,em sucessão rítmica. Rodovia Raposo Tavares, $\mathrm{km} 83$, a $3 \mathrm{~km}$ de Brigadeiro Tobias para Alumínio. 


\section{ROCHAS CALCẢRIAS E CALCO-SILICATADAS}

As rochas calcárias formam corpos lenticulares dis tribuídos desde a região de Salto de Pirapora até Pantojo, a maioria bordejando o Maciço de São Francisco.

Têm granulação fina, textura maciça e cores cinza-clara e preta. Conforme Bettencourt (1971), as mais escu ras são calcários e calcários magnesianos, enquanto as mais claras são calcários dolomíticos, dolomitos calcíticos e do lomitos.

Tais rochas se constituem essencialmerte de carbona tos em grãos mais ou menos equidimensionais, compondo um mo saico granoblástico. Os cristais frequentemente exibem gemi nação polissintética $e$, não raramente, observam-se flexões das lamelas e dos planos de clivagem.

0 acessório mais comum é o quartzo, err grãos subarre dondados, às vezes achatados e isorientados. Exibe extinção ondulante sob nícois cruzados.

Matéria carbonosa finamente dividida e dispersa res ponde pelas cores cinza e preta. Localmente aparecem lâmi nas de espessura milimétrica de grafita-xisto.

Outros acessórios são: moscovita, biotita e clorita, em plaquetas isorientadas.

A quantidade de quartzo e moscovita (sericita) às ve zes é alta, constituindo-se os chamados filitos calcários,que correspondem a transição entre filito e calcário, derivando de sedimentos margosos. Vez ou outra é o quartzo que assume proporções de predominância, constituindo-se quartzitos cal cários ou calcários quartzíticos.

Veios de calcita branca, de espessura milimétrica ou submilimétrica, são comuns, cortando a rocha segundo comple xo reticulado. Veios e bolsões de quartzo também aparecem. 
sendo por vezes opservável concordância e discordância com a estratificação reliquiar.

As ocorrências de rochas calcárias são restritas, as sociando-se a hornfels calco-silicáticos, resultantes da ação de contato dos corpos granitóides sobre antigos sedimen tos sílico-carbonatados.

Um enorme corpo de hornfels calco-silicatado ocorre embutido no Batólito de São Roque e foi descrito minuciosa mente por Coutinho (1953) e Franco (1958). Constitui-se de dolomitos metamórficos, portando tremolita, diopsídio, anti gorita, talco, albita, quartzo, pirita e calcita. Também oli goclásio, microclíneo, clinozoisita, flogopita, titanita e turmalina aparecem em alguns leitos.

Bordejando o maciço de São Francisco, desde a Serra de Inhaíba até a região de Salto de Pirapora, também apare cem rochas similares constituindo a maior parte dos corpos indicados nos mapas anexos.

No canto nordeste da Folha de São Roque também apare cem rochas calco-silicáticas bandadas análogas àquelas des critas por Cordani et al. (1963) na região de Perus.

\section{METABASITOS}

Dois corpos de metabasitos foram identificados

na borda sudeste do Maciço de São Francisco. Ambos foram ante riormente reconhecidos por Hasui et al. (1969).

0 maior deles, exibe em sua parte leste rochas de granulação fina a média, cor verde escura e constituídas por cristais de plagioclásio ripiformes, com composição de labra dorita sódica, quase totalmente sausuritizados e em arranjo sem orientação preferencial. O máfico presente é actinolita-tremolita poiquiloblástica, também com desenvolvimento alon gado e sem orientação. Junto ao contato com o corpo graníti 
co, a rocha se constitui de oligoclásio, em grãos subédricos e anédricos, mais ou menos equidimensionais, de permeio a prismas de hornblenda, às vezes poiquiloblásticos, sem orien tação preferencial.

Os acessórios são: titanita, em cristais subédricos e normalmente pequenos, mas às vezes mais desenvolvidos, até porfiroblásticos; clorita e biotitia, em pequenas quantidades, dispersas sem orientação preferencial; apatita e mineral opa co, em grãos minúsculos euédricos e subédricos. Quartzo é um acéssório universal, em quantidades inferiores a $15 \%$ sem pre xenomorfo e exibindo extinção ondulante sob nícois cruza dos. Nas vizinhanças do corpo granítico, veios de quartzo estão presentes, com espessuras até decimétricas.

o corpo menor, adjacente ao maciço granítico, é cons tituído por anfibolito típico, com prismas de hornblenda de senvolvendo textura nematoblástica e plagioclásio (andesina) em grãos menores e mais ou menos equidimensionais.

\section{ROCHAS GRANITÓIDES}

Os maciços granitóides de Sorocaba, São Francisco e São Roques mostrados na Figura 4, foram já anteriormente des citos por Hasui et al. (1969).

Os dois primeiros são análogos, constituindo-se de rochas inequigranulares a porfiríticas, de cor rosada ou cin zenta, de aspecto homogêneo. Cristais bem desenvolvidos de microclíneo pertítico e oligoclásio chegam a ter até $2 \times 3$ $-4 \mathrm{~cm}$. Têm contornos elíticos a retangulares. São norma mente poiquiloblásticos, o microclíneo contendo grãos meno res de quartzo, mica e plagioclásio e o plagioclásio encer rando inclusões de quartzo e mica. Esses cristais maiores se destacam em superfícies de matacões e lagedos, formando nódulos salientes.

Na parte mais fina comparecem quartzo, os mesmos 
feldspatos, biotita, titanita, moscovita, zircão,

mineral opaco, apatita, carbonato, epídoto e fluorita. Intercresci mentos mirmequíticos não são raros. As micas e algum quart zo desenvolvem uma foliação conspícua, a qual em volta dos cristais maiores acha-se parcialmente truncada e em parte desviada. Com isso, a foliação não é planar, mas muito ondu lada. Quando os cristais maiores exibem orientação preferen cial linear ou planar, ela é concordante com a foliação;essa situação, porém, não é comum, pois em geral eles mostram dis tribuição caótica.

o plagioclásio às vezes exibe sericitização parcial, bem como zoneamento normal, com borda mais södica.

0 quartzo mostra extinção ondulante a nícois cruza dos; lamelas de plagioclásio e placas de micas estão por ve zes fletidas; os feldspatos apresentam-se geminados - tais feições parecem ser protoclásticas (Wizliams et al., 1954). Todavia, quase que generalizadamente vêm-se indícios de de formação mais avançada, criando texturas em moldura em felds patos e granulando quartzo.

A composição total da rocha varia de granitica a ada melitica, o mesmo acontecendo com a parte mais fina. Essas variações composicionais não são distinguíveis no campo.

Os cristais maiores de feldspatos formaram-se tardia mente na rocha, a julgar pelas inclusões (Guimarães, 1964), bem como pelo fato de na maioria dos casos não se apresenta rem orientados, fato que voltaremos a considerar adiante.

Nesses dois maciços ocasionalmente aparecem massas de dezenas de metros de extensão no terreno constituídas por metamorfitos. Tal é o caso, por exemplo, do quartzito a su deste de Sorocaba. 0 quartzito exibe dobras centimétricas fechadas, visíveis graças à alternância de faixas mais ricas ou mais pobres em moscovita e biotita. A rocha tem textura granolepidoblástica, com a xistosidade paralela aos planos axiais das dobras. Zircão, mineral opaco, microclíneo pertí 
tico e oligoclásio são os acessórios menores. Também corpos de rochas calco-silicatadas existem na metade oeste do maci ço de são Francisco (J.S. Bettencourt, comunicą̧̃o pessoal). Inclusões menores de xistos são vistas ocasionalmente.

Nas bordas dos maciços, localmente existem zonas quartzo-dioríticas, com até centenas de metros de extensão. As rochas ai têm granulação fina, com foliação nitida e cor cinza-escura. Constituem-se essencialmente de plagioclásio (oligoclásio a andesina sódica), normalmente exibindo serici tização parcial. Os grãos são subédricos e anédricos e for mam uma massa hipidiormórfica granular. Hornblenda em cris tais subédricos e xenomorfos, às vezes envolvendo núcleos de augita, e biotite em placas parcialmente cloritizadas, são os acessórios responsáveis pela foliação da rocha. Titanita, apatita, mineral opaco e zircão são os acessórios menores,em pequenos cristais subédricós e euédricos. Quartzo está sem pre presente em grãos xenomorfos e com extinção ondulante a nícois cruzados, perfazendo teores de até $1.0 \%$.

No tocante à forma dos corpos, eles são alongados se gundo a orientação geral dos dobramentos das encaixantes. Os contatos são abruptos, isto é, são corpos circunscritos (R $\underline{a}$ guin, 1965). Localmente, são discordantes, sobretudo nas ex tremidades, mas em geral guardam relação de concordância com as encaixantes.

Entre Sorocaba e Salto de Pirapora estende-se o Gru po Tubarão recobrindo o Maciço de Sorocaba. Manchas dessa unidade sedimentar foram isoladas pela erosão em alguns lo cais, como se vê nos mapas geológicos anexos.

- Maciço de São Francisco em sua borda meridional foi seccionado pelo Falhamento de Pirapora.

Quanto ao Batólito de São Roque,é ele truncado a sul pelo Falhamento de Pirapora e a oeste pelo Falhamento de São Roque (Hasui et al. 1969). Compõe-se de rochas conhecidas 
por "Granito" tipo Pirituba (Moraes Rego e Souza Santos, 1938) ou tipo Varejão (FZorence, 1907). Petrograficamente são idên ticas às rochas do Complexo Piedade que descreveremos adiante, pelo que nos eximimos aqui da descrição.

\section{BLOCO ITUPARANGA}

O Bloco Ituparanga se constitui de metassedimentos e três pequenos corpos intrusivos de rochas granitóides.

Os metassedimentos são representados essencialmente por filitos, quartzo-filitos e quartzitos, idênticos aos des critos anteriormente, jnclusive mostrando estratificação rít mica. Faltam termos calcários e metabasiticos.

Nas proximidades dos corpos granitóides aparecem mica xistos também análogos aos do Bloco São Roque.

Os três corpos granitóides são os de Pirapora, o das Lavras e o da Represa (Figura 4), todos com litologia idênti ca à do Complexo Piedade, que descreveremos no item seguinte.

\section{BLOCO COTIA}

Neste bloco encontramos ectinitos com metabasitos as sociados, migmatitos e corpos intrusivos de rochas granitói des. Os primeiros se expõem numa faixa que se estende da ser ra dos Lopes para sudoeste, na Folha de Pilar do sul. Os mig matitos aparecem nas bordas normais do Complexo Piedade e em massas rochosas nele embutidas.

\section{ECTINITOS}

Os ectinitos são representados mormente por filitos, quartzo-filitos e quartzitos petrograficamente análogos àque les do Bloco São Roque, inclusive em sequências rítmicas. Ação pneumatolítica-metassomática é observada, pela formação de 
porfiroblastos de turmalina, apatita, pirita e moscovita nas proximidades dos corpos graniticos. Cristais prismáticos e faixas desses minerais se relacionam com a xistosidade e com os planos da foliação de crenulação, adiante descrita.

Nas bordas do maciço de Pilar do Sul, desenvolveram- se moscovita-hornfels, com placas de moscovita de até 2 -3mm sem orientação preferencial. Também veios de quartzo se in filtraram nos filitos (Fotomicrografia l).

Junto ao Complexo de Piedade, interpõe-se uma faixa de micaxistos análogos àqueles descritos no Bloco são Roque. Essa faixa, a leste de Pilar do sul. tem maior largura, achan do-se indicada no mapa geológico anexo.

Ação pneumatolítica-metassomática também se fez sen tir nesses xistos, desenvolvendo-se os mesmos minerais. A Fo tomicrografia 2 mostra porfiroblastos de moscovita e de tur malina.

\section{METABASITOS}

Os metabasitos associados a esses ectinitos formam dois corpos a sudeste de Pilar do Sul, concordantes com a es tratificação reliquiar dos metapelitos. São rochas de granu lação fina, cor verde escura a preta e com foliação pouco desenvolvida. Os minerais essenciais são actinolita-tremoli ta, plagioclásio e clorita. Os anfibólios são euédricos ou subédricos, de dimensões variadas, os maiores sendo poiquilo blásticos com inclusões de quartzo. Dispõem-se suborientada mente. o plagioclásio é subédrico, sem orientação; tem com posição de andesina sódica e se acha fortemente saussuritiza do. A clorita constitui placas em parte orientadas. Os aces sórios são: titanita, apatita e mineral opaco. o reticulado de ripas de plagjoclásio, ainda que vagamente discernível, su gere origem do metabasito a partir de rocha ígnea básica. 


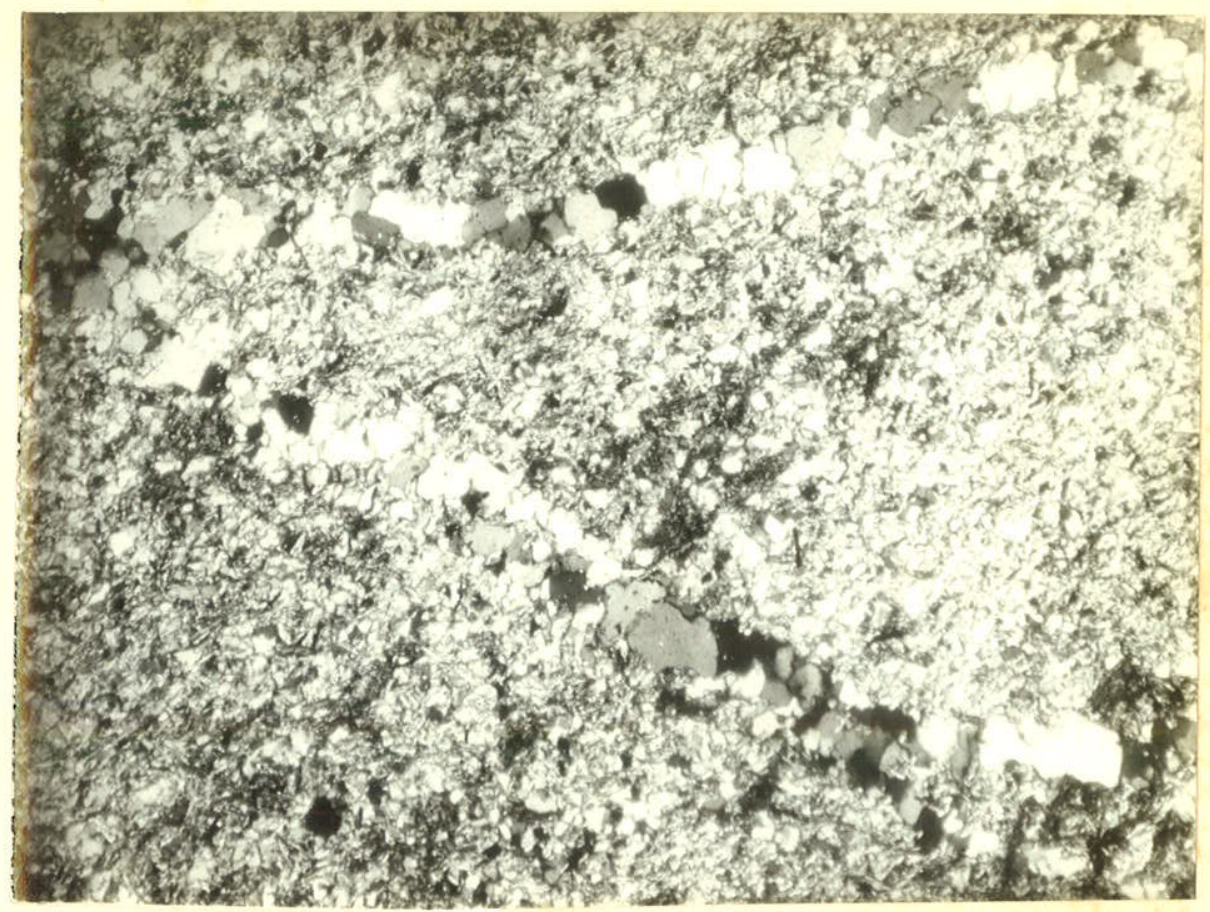

FotomicrografiA 1 - Veios de quartzo discordantes com a xiś tosidadelalinhamento canto superior direito/canto inferior esquerdo). O quart zo não exibe extinção ondulante: Os veios não estão deformados.

$480 \times \mathrm{N}+$. Amostra 226, micaxisto, $8 \mathrm{~km} \mathrm{a}$ SE de Pilar do Sul. 


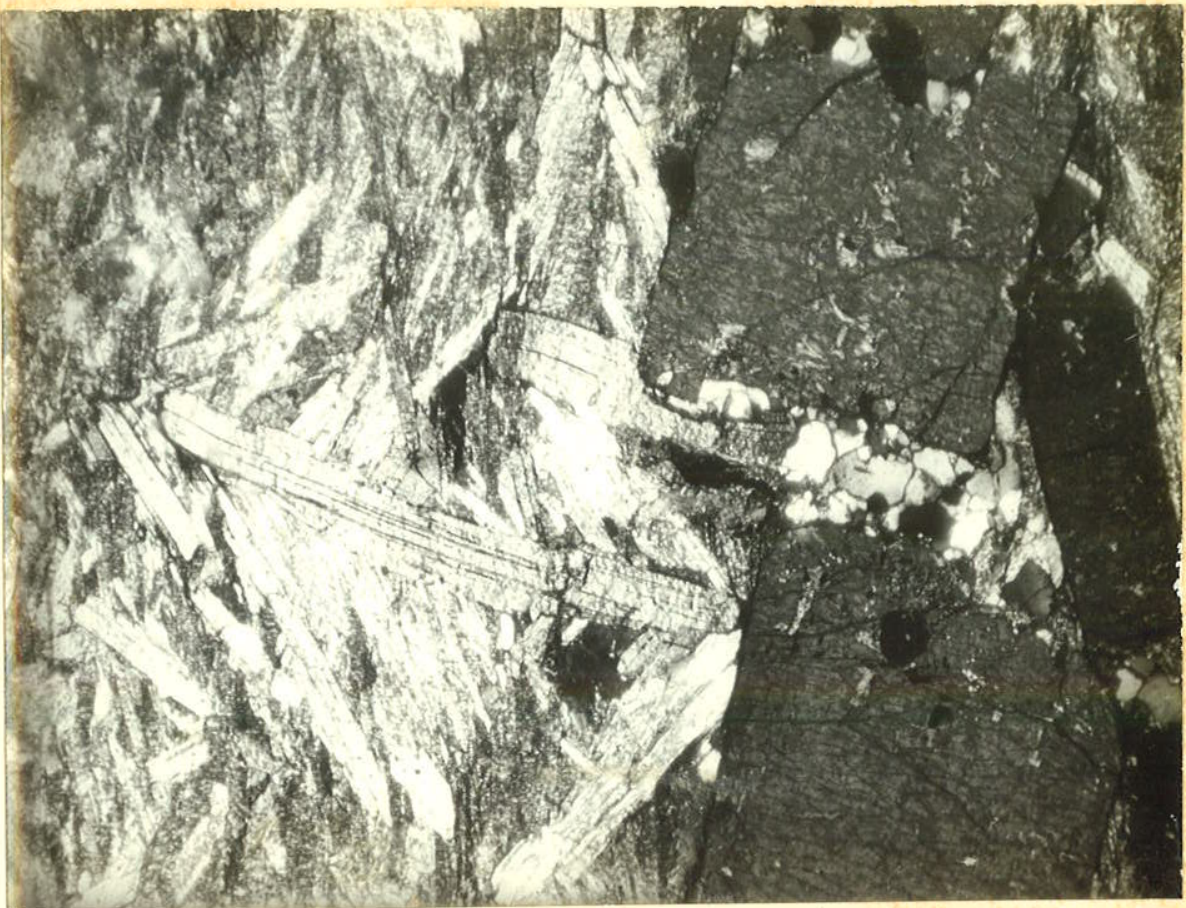

FOTOMICROGRAFIA 2 - Porfiroblastos de moscovita e de turmalina no micaxisto, os primeiros discordantes e os segundos concordantes com a xistosidade.

$192 \times \mathrm{N}+$. Amostra 233, 7.5 km ENE de Pilar do sul. 


\section{MIGMATITOS}

Em uma faixa na orla ocidental do Complexo Piedade e em corpos nele embutidos, aparecem metamorfitos migmatiza dos. Os corpos inclusos no Complexo parecem corresponder a porções do teto e os menores, a xenólitos. É possível que investigações mais pormenorizadas encontrem outros corpos pe quenos dispersos.

o major desses corpos tem início a sul de Vila Élvio, estendendo-se para NE até o vale do rio sorocä-Buçu, onde se inflete para norte. No vale do Sorocá-Mirim, a faixa se di rige para leste até a região de Vargem Grande e para oeste até Ibiúna. Na região da Serra de São Sebastião e do vale do Ribeirão Rafael. Grande, a faixa foi truncada pelo falha mento de Caucaia.

Todos esses corpos, bem como a faixa marginal, cons tituem-se de migmatitos predominartemente com estrutura es tromatitica (Mehnert, 1968), em que o paleossoma é a parte mais destacada. Estruturas dictionitica, em placa e flebiti ca são observadas restritamente, em um ou outro afloramento.

Os contatos entre os corpos migmatiticos e as rochas granitóides do Complexo de Piedade são sempre abruptos.

o termo migmatito foi introduzido por J.J. Sederholm em 1907 para se referir a rochas heterogêneas, com frações gnáissicas ou xistosas e outras granitóides, perfeitamente discerníveis em amostras ou afloramentos. Posteriormente, desenvolveram-se emi paralelo classificações de tipos diferen tes de migmatitos e teorias para explicar a formação de cada um. Também o conceito foi expandido para abarcar tipos de aspecto uniforme, que no campo mostram passagens graduais pa ra tipos bifásicos. Assim, numerosos termos foram introduzi dos, mas todos com conotações genéticas.

Não nos cabe aqui rever o assunto, mas merece ser 
lembrada a classificação de Jung e Roques (1952), separando migmatitos heterogêneos (epibolitos, diadisitos e agmatitos) e homogêneos (embrechitos e anatexitos), aos quais eles atri buiram origem metassomática por intercâmbio iônico entre o paleossoma e fluidos (ichor, de proveniência não necessaria mente magmátical, que o percolariam através de zonas de re sistência mínima. Se o modelo genético foi combatido por adeptos de outros mecanismos genéticos (injeção magmática, fusão diferencial+segregação), a classificação teve grande pe netração nos meios geológicos pela simplicidade e facilidade de aplicação no campo, pelo menos no que diz respeito aos ti pos bifásicos. Turner e Verhoogen (1960), como muitos ou tros autores, acharam preferível voltar à acepção original do termo migmatito, excluindo os tipos homogêneos.

Na década passada tornou-se clara a necessidade de se desvincular classificação e origem e, assim, algumas clas sificações surgiram puramente descritivas. É o caso da de Mehnert (1968) que aqui adotamos.

\section{Paleossoma}

O paleossoma é representado por gnaisses, micaxistos e quartzo-micaxistos. Também intercalações de quartzito cal co-silicático são encontradas, como a leste de Piedade, den tro dos xistos.

Os micaxistos compõem-se essencialmente de biotita, moscovita e quartzo, em proporções variadas, como se vê pe las análises modais da Tabela 1 .

As micas são os componentes principais, dominando ora moscovita, ora biotita. Elas desenvolvem xistosidade, mas parte da moscovita forma porfiroblestos que são predominante mente discordantes com essa foliação e sem orientação prefe rencial. Cada porfiroblasto em dois lados trunca a foliação e, no restante, desvia a xistosidade, ondulando-a. 
TABELA 1

ANALISES MODAIS DE MICAXISTOS (PALEOSSOMA)

$\begin{array}{lrrrr}\text { AMOSTRA N } & 155 & 176 & 103 & 180 \\ \text { Ne PONTOS } & 1077 & 1012 & 1113 & 1708 \\ \text { Quartzo } & 20,8 & 26,3 & 30,6 & 10,4 \\ \text { Biotita } & 41,7 & 34,9 & 23,9 & 58,3 \\ \text { Moscovita } & 30,3 & 33,8 & 43,8 & 24,6 \\ \text { Clorita } & 5,2 & 3,3 & 0,6 & 5,7 \\ \text { Mineral opaco } & 1,7 & 1,5 & 1,0 & 0,9 \\ \text { Zircão } & 0,3 & 0,2 & 0,1 & 0,1 \\ \text { Apatita } & \text { pr. } & - & \text { pr. } & - \\ \text { Turmalina } & \text { pr. } & \text { pr. } & \text { pr. } & -\end{array}$

Am. 155 - $14.5 \mathrm{~km}$ a SSE de Ibiúna.

Am. 176 - $16 \mathrm{~km}$ a SSE de Ibiúna.

Am. 103 - $1 \mathrm{~km}$ a NW de Piedade.

Am. $180-13,5 \mathrm{~km}$ a SE de Ibiúna.

o quartzo é xenomorfo, com extinção ondulante sob nícois cruzados. Os grãos são achatados ou se grupam em agregados lenticulares, orientando-se em concordância com as micas. O seu teor varia muito, passando a quartzo-micaxistos, dos quais algumas análises modais executadas são mostradas na Tabela 2 .

A clorita está presente em associação com a biotita. Mineral opaco, zircão e apatita formam minúsculos grãos subé dricos dispersos. Turmalina bem desenvolvida está presen te ocasionalmente.

Em algumas amostras de xistos vêem-se também horn blenda, granada, actinolita-tremolita, minerais do grupo do epídoto, oligoclásio e microclíneo, em quantidades irrisó rias. Estes dois últimos, em algumas faixas, assumem teo res altos, passando então a gnaisses.

Camadas e lâminas com diferentes composições se su cedem, indicando sedimentação rítmica do antigo sedimento.

o quartzito calco-silicatado forma camadas de espes 
TABELA 2

ANÁLISES MODAIS DE QUARTZO-MICAXISTOS (PALEOSSOMA)

\begin{tabular}{|c|c|c|c|}
\hline AMOSTRA N $N^{8}$ & 110 & 109 & 203 \\
\hline N: PONTOS & 1060 & 1299 & 1250 \\
\hline Quartzo & 33.3 & 35.0 & 48,6 \\
\hline Biotita & 23,3 & 36,1 & 13,1 \\
\hline Moscovita & 41,3 & 24,7 & 37,3 \\
\hline Clorita & 0,9 & 2,7 & 0.3 \\
\hline Mineral opaco & 1,0 & 1.3 & 0.7 \\
\hline Zircão & 0,2 & 0,2 & pr. \\
\hline Apat1ta & - & $p r$. & pr. \\
\hline Turmalina & pr. & pr. & \\
\hline
\end{tabular}

Am. 110 - $1 \mathrm{~km}$ a NW de Piedade.

Am. 109 - $1 \mathrm{~km}$ a NW de Piedade.

Am. 203 - $4 \mathrm{~km}$ a SE de Piedade.

sura até decamétricas e tem aparência sacaróide, granulação fina e cor cinza-clara a cinza-esverdeada. A sua alteração intempérica produz areias finas, argilosas, de cor vermelha. Uma ligeira foliação é desenvolvida por minerais prismáticos e por quartzo achatado.

A Tabela 3 mostra a composição mineralógica de um quartzito calco-silicático.

o quartzo é xenomorfo, exibindo extinção ondulante a nícois cruzados, sendo equigranular ou achatado. 0 plagio clásio tem composição labradorítica e seus grãos são mais ou menos equidimensionais. Os demais compcrentes estão dispersos, ou formando agregados que maculam a rocha com pontos mi limétricos verdes ou vermelho-claros. 
TABELA 3

ANALISE MODAL DE QUARTZITO CALCO-SILICATICO

$\begin{array}{lc}\text { AMOSTRA No } & 111 \\ \text { Ne Pontos } & 1295 \\ \text { Quartzo } & 68,1 \\ \text { Plagiocläsio } & 18,4 \\ \text { Grupo do epidoto } & 6,4 \\ \text { Hornblenda } & 3,5 \\ \text { Titanita } & 1,2 \\ \text { Granada } & 1,0 \\ \text { Biotita } & 0,7 \\ \text { Apatita } & 0,3 \\ \text { Mineral opaco } & 0,2 \\ \text { Zircão } & 0,2 \\ \text { Carbonato } & \mathrm{pr} . \\ \text { Ciorita } & \mathrm{pr} .\end{array}$

Am. Ill - l km a $N$ de Piedade.

\section{Neossoma}

0 neossoma tem granulação fina, média ou grossa, for mando faixas, bolsões e lentes com espessuras de milímetros a metros e concordantes com a xistosidade do paleossoma. Quartzo, microclíneo pertítico e oligoclásio são os minerais essenciais, definindo composições graníticas a granodioríticas. Biotita, moscovita, clorita, mineral opaco e zircão são os acessórios; totalizam baixas percentagens, pelo que - neossoma é leucocrático. As micas nos neossomas de granu lação fina e média estão orientadas, impondo-lhes uma folia ção que é paralela à do paleossoma. 


\section{ROCHAS GRANITÖIDES}

As rochas granitóides no Bloco Cotia compõem cinco corpos, a que designamos Complexo de Piedade e Maciços de São Miguel Arcanjo, de Pilar do Sul, da Serra do Lopes e do Tur vo, como se vê na Figura 4.

\section{Complexo Piedade}

0 Complexo Piedade é constituído pelo chamado "Grani to" tipo Pirituba. Sendo este tipo litológico dos mais fre quentes na área e talvez do Pré-Cambriano paulista, escolhe mos esse Maciço para um exame mais detalhado.

Na realidade, o que se chama "Granito" tipo Pirituba inclui rochas granitóides de três tipos texturalmente diver sos: porfiríticas, inequigranulares e finas.

As rochas porfiriticas têm fenocristajis róseos e/ou cinza-claros, com dimensões variadas, desde aqueles que pou co contrastam com a matriz até aqueles bem salientes de até 2-3 $\times$ 7-8 cm. Neste caso, de longe chamam a atenção do ob servador, pois se destacam pela cor em superfícies sãs ou al teradas, ou sob a forma de caroços salientes em superfícies de matacões ou lagedos, o que, aliás, levou Florence (1907) a usar a designação Varejão para tais rochas. São monocrís tais de microclíneo pertítico e oligoclásio. 0 primeiro apresenta maior desenvolvimento e ambos têm seções retangu lares, subretangulares, elíticas e ocelares. Normalmente são poiquiliticos, incluindo grãos de quartzo, micas e feldspa tos.

A matriz é cinza-clara a cinza-escura, de granula ção fina ou fina a média. Os minerais essenciais são quart zo, microclíneo e oligoclásio, que compõem uma textura hipi diomórfica granular. o acessório principal é a biotita, se 
guindo-se hornblenda, titanita, zircão, epídoto, mineral opa co, apatita, carbonato e moscovita. Intercrescimentos mir mequíticos e micropegmatíticos são comuns.

A biotita, hornblenda, moscovita e algum quartzo de senvolvem uma foliação notável, que ao redor dos fenocrís tais se apresenta em parte truncada, em parte conturbada em ondulações (Fotomicrografia 3 ).

A Tabela 4 mostra os resultados de sete análises mo dais em exemplares de aspectos macroscópicos diferentes, re presentativos das variações observadas no campo. Nota-se que - volume de fenocristais varia entre $1 / 3$ e $2 / 3$ da rocha. Es tão sempre presentes os dois tipos de feldspatos, predominan do um ou outro, aparentemente sem regra geral.

A matriz tem predominantemente constituição granodio rítica e, por vezes, adamelitica. Em termos de rocha total, a Tabela 5 mostra que ela varia de granítica a granodioritica.

Na maior parte do Complexo de Piedade, porém, as ro chas granitóides não são porfiríticas, mas ineqüigranulares seriadas. A dimensão dos minerais essenciais varia de menos de l mm até 4-5 cm, mas os limites extremos oscilam muito de local para local. Os acessórios têm dimensões de algumas mi cra até $2-3 \mathrm{~mm}$.

Os grãos mais desenvolvidos são de microclíneo per títico elou oligoclásio, que mostram seções sub-retangulares ou elíticas. A parte fina, com grãos menores que $2 \mathrm{~mm}$,é com parável à matriz da variedade porfirítica.

A Tabela 6 mostra composições modais de cinco amos tras escolhidas de modo a representar tipos distinguiveis ma croscopicamente. Vê-se que a composição, em termos totais,é granitica. No exame da fração fina, em dezenas de lâminas, há predomínio quase geral de plagioclásio sobre feldspato po tássico, o que traduz sua natureza granodiorítica.

Frequentemente, aparecem faixas e zonas centimétri 


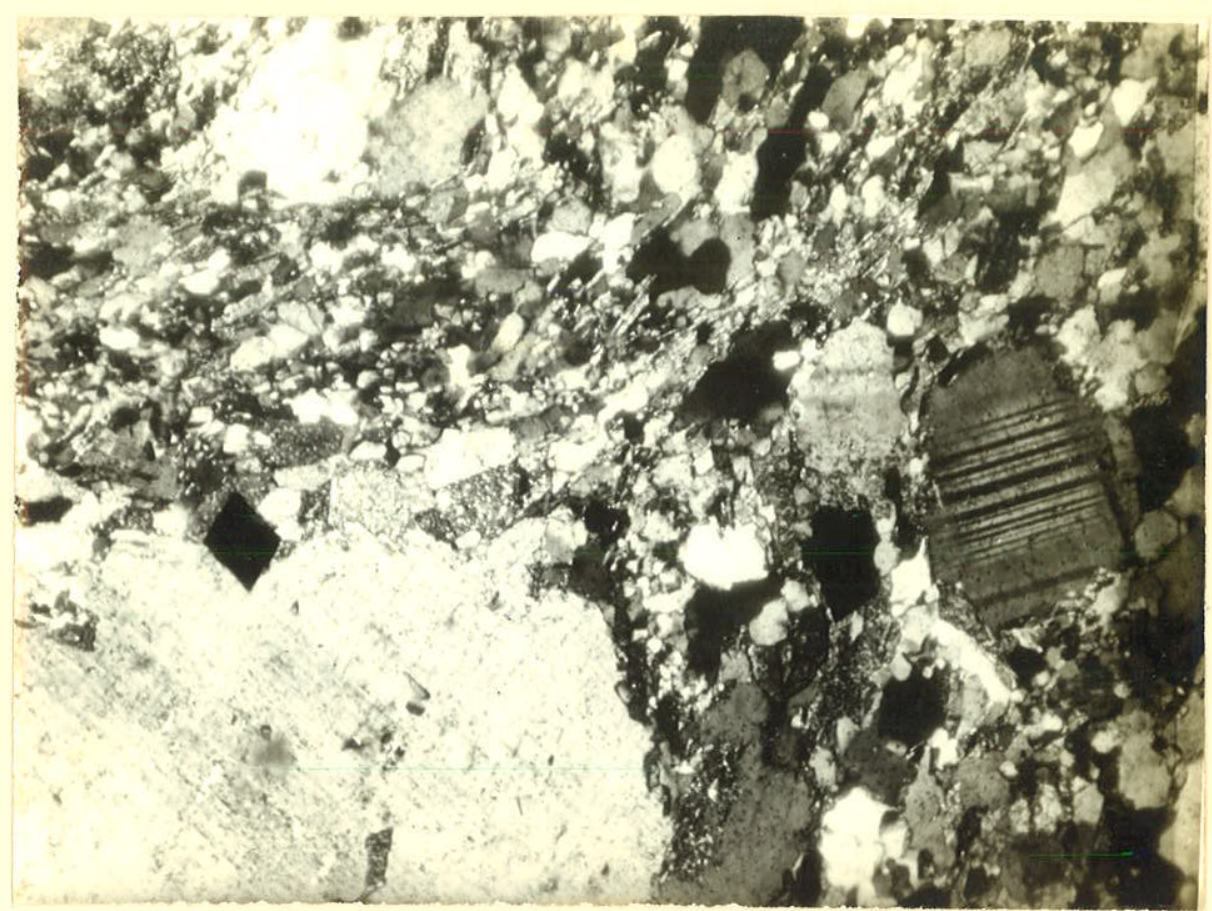

FOTOMICROGRAFIA 3 - Fenocristais no "Granito" tipo Pirituba e a foliação da matriz por eles desviada. Cristais de biotita e quartzo mais desenvolvidos aparecem nas zonas de som bra.

192X N+. Amostra 114, 2 km NNE de Pieda de. 
TABELA 4

COMPOSIÇAOO MODAL DAS ROCHAS GRANITUIDES PORFIRITICAS DO COMPLEXO PIEDADE

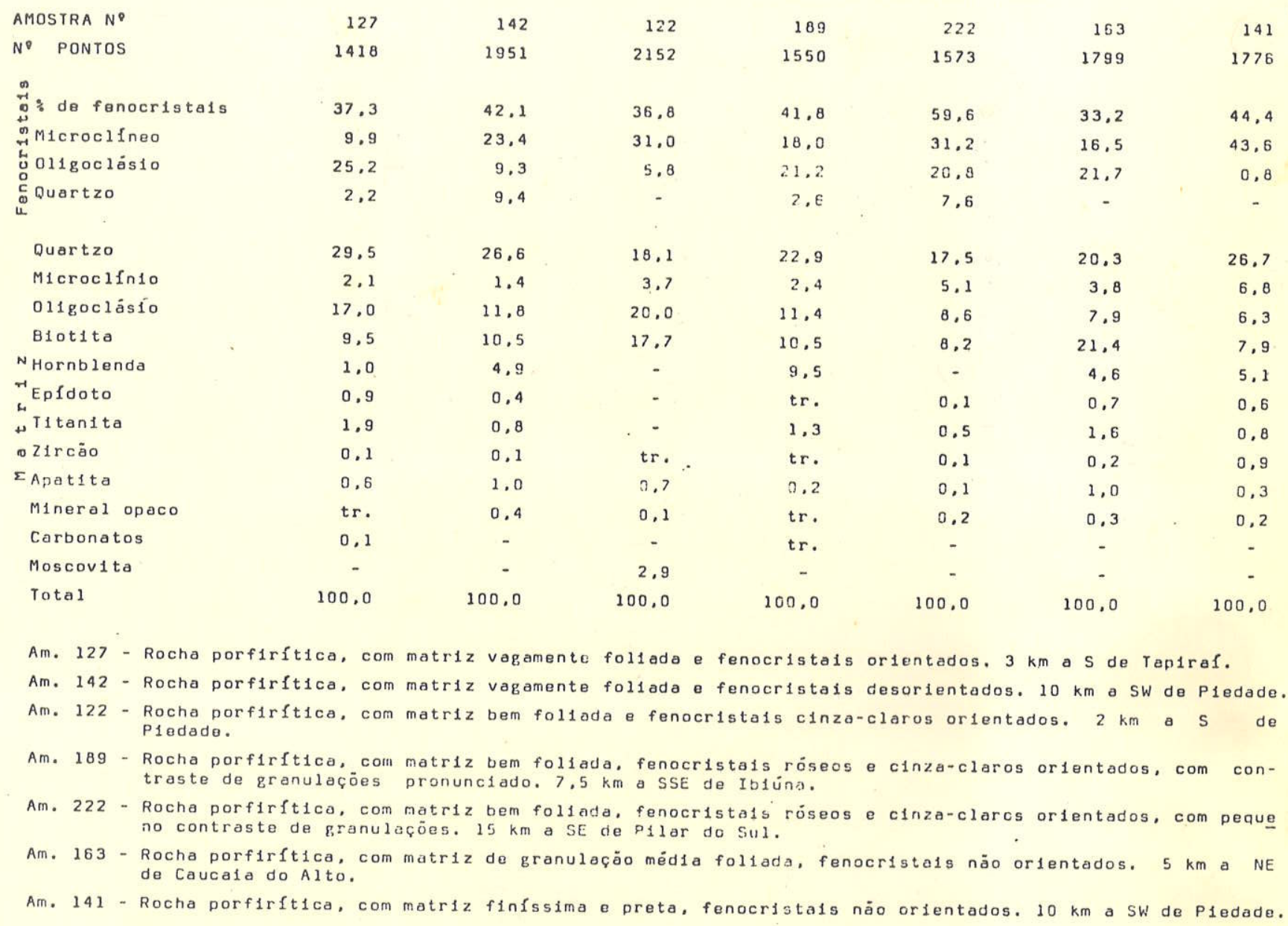


TABELA 5

COMPOSIÇÃO MODAL TOTAL DAS ROCHAS GRANITOIIDES PORFIRITICAS DO COMPLEXO PIEDADE

\begin{tabular}{|c|c|c|c|c|c|c|c|}
\hline AMOSTRA N: & 127 & 142 & 122 & 189 & 222 & 163 & 141 \\
\hline Quartzo & 31,7 & 36,0 & 18,1 & 25,5 & 25,1 & 20,3 & 26,7 \\
\hline Microclíneo & 12,0 & 24,8 & 34,7 & 20,4 & 36,3 & 20,3 & 50,2 \\
\hline Oligoclásio & 42,2 & 21,1 & 25,8 & 32,6 & 29,4 & 29,6 & 7,1 \\
\hline Acessórios & 14,1 & 18,1 & 21,4 & 21,5 & 9,2 & 23,8 & 16,0 \\
\hline TOTAL & 100,0 & 100,0 & 100,0 & 100,0 & 100.0 & 100,0 & 100,0 \\
\hline
\end{tabular}


TABELA 6

COMPOSIÇÃO MODAL DE ROCHAS GRANITÓIDES INEQUIGRANULARES DO COMPLEXO PIEDADE

\begin{tabular}{|c|c|c|c|c|c|}
\hline AMOSTRA $N^{8}$ & 211 & 112 & 204 & 174 & 125 \\
\hline N: PONTOS & 1776 & 1214 & 1283 & 1494 & 1390 \\
\hline Quartzo & 36,2 & 23,4 & 31.5 & 33,9 & 39,4 \\
\hline Microclíneo & 35,2 & 40,5 & 47.0 & 33.1 & 23,6 \\
\hline Oligoclásio & 21,9 & 27,1 & 12,2 & 15.7 & 19.3 \\
\hline Biotita & 4,7 & 6.2 & 7.0 & 13,3 & 16,9 \\
\hline Hornblenda & - & - & 0.2 & 0.9 & - \\
\hline Ortopiroxēnio & - & - & - & 0,8 & - \\
\hline Epídoto & tr. & 0.1 & - & 0,4 & 0,2 \\
\hline Titanita & 0,8 & - & - & 0,6 & $\operatorname{tr}$ \\
\hline Zircão & 0.1 & - & 0.1 & 0,1 & - \\
\hline Apatita & 0,4 & 0,3 & 0,1 & 0,2 & 0,2 \\
\hline Mineral opaco & 0,7 & 0,1 & 0.6 & 1.0 & 0,4 \\
\hline Carbonatos & - & - & - & - & - \\
\hline Moscovita & - & 2,3 & 1,3 & - & - \\
\hline Total & 100,0 & 100,0 & $100,0$. & 100,0 & 100,0 \\
\hline
\end{tabular}

Am. 211 - Rocha inequigranular seriada, com foliação pouco evidente.

Am. 112 - Rocha inequigranular seriada, com foliação e granulação de fina a média. l km a $\mathrm{N}$ de Piedade.

Am. 125 - Rocha inequigranular seriada, com foliação, granu lação de fina a grossa e cor cinza escura. $6,5 \mathrm{~km}$ a $\mathrm{N}$ de Tapiraí.

Am. 204 - Rocha inequigranular seriada, com foliação conspí cua, granulação de fina a grossa e cor cinza-clara. l km a SE de Vila Ëlvio.

Am. 174 - Rocha inequigranular seriada, com foliação conspí cua, granulação de fina a grossa e cor cinza-médía. $2 \mathrm{~km}$ a W de Caucaia do Alto. 
cas a quilométricas de rochas de granulação fina a muito fi na, de cores cinza-média a cinza-escura. Seus limites não são nitidos, graduando para variedades mais grossas. Um exem plo de zona desse tipo se encontra na Serra de Taxaquara,sus tentando-a. Hasui et al. (1969) consideraram-na como um ma ciço granitóide sintectônico.

Texturalmente, essas rochas finas diferem das ineqü granulares seriadas apenas na granulação, isto é, elas tam bém são inequigranulares seriadas, mas com limites de dimen sões submilimétricas.

Na Tabela 7 apresentamos algumas análises modais de rochas finas. Nota-se que mineralogicamente não diferem das anteriores. Quantitativamente, a diferença notável está nos teores mais elevados de quartzo.

Tais rochas são qualificáveis como graniticas, adame liticas e granodioríticas.

Em todas essas rochas granitóides do Complexo Pieda de, o quartzo é sempre xenomorfo, exibindo extinção ondulan te a nícois cruzados. Forma os menores grãos dentre os es senciais, mas também pode constituir massas maiores de até 3-4 mm de diâmetro. Frequentemente são achatados e contri buem para o desenvolvimento da foliação.

o microclíneo é pertitico, normalmente de cor rósea, mas às vezes é cinzento. É subédrico ou xenomorfo; os casos de euedrismo se limitam a cristais maiores. Todos os grãos mais desenvolvidos são poiquilíticos, incluindo grãos de quartzo, plagioclásio e biotita (Fotomicrografia 4).

o plagioclásio é oligocilásio, com geminação da Albita e ocasionalmente combinando as leis Albita-Periclíneo ou Al bita-Carlsbad. As vezes é zonado normalmente, com borda mais sódica. Tem sempre cor cinzenta e é subédrico ou ané drico. Quando mais desenvolvido, é poiquilitico, incluindo grãos de quartzo, microclíneo e biotita. 
TABELA 7

COMPOSIÇÃO MODAL DE ROCHAS GRANITÓIDES FINAS DO COMPLEXO PIEDADE

$\begin{array}{lccccr}\text { AMOSTRA Ne } & 114 & 161 & 124 & 197 & 195 \\ \text { Ne Pontos } & 1206 & 1408 & 1534 & 2365 & 1156 \\ \text { Quartzo } & 52,0 & 47,0 & 47,0 & 42,2 & 41,1 \\ \text { Microclíneo } & 10,8 & 24,3 & 17,8 & 10,8 & 22,1 \\ \text { Oligocläsio } & 13,7 & 8,5 & 23,9 & 36,9 & 10,2 \\ \text { Biotita } & 18,2 & 13,8 & 9,0 & 9,2 & 18,0 \\ \text { Hornblenda } & 0,6 & - & - & - & 3,7 \\ \text { Ortopíroxênio } & -. & - & - & 0,3 & - \\ \text { Epidoto } & 2,1 & 0,1 & 0,1 & \text { tr. } & 2,8 \\ \text { Titanita } & 0,6 & 1,4 & \text { tr. } & 0,1 & 0,8 \\ \text { Zircão } & \text { tr. } & 2,4 & 0,1 & \text { tr. } & 0,2 \\ \text { Apatita } & 0,5 & 0,3 & 0,3 & \text { tr. } & 0,8 \\ \text { Mineral opaco } & 0,4 & 2,0 & 0,9 & 0,1 & 0,3 \\ \text { Carbonatos } & 0,9 & - & 0,2 & - & - \\ \text { Moscovita } & 0,2 & 0,2 & 0,7 & 0,4 & - \\ \text { Total } & 100,0 & 100,0 & 100,0 & 100,0 & 100,0\end{array}$

Am. $114-1,5 \mathrm{~km}$ a NNW de Piedade.

Am. $161-3,5 \mathrm{~km}$ a $\mathrm{NE}$ de Ibiüna.

Am. $124-15,5 \mathrm{~km}$ a SSW de Piedade.

Am. 197 - $6 \mathrm{~km}$ a ESE de Piedade.

Am. 195 - $9,5 \mathrm{~km}$ a ENE de Piedade. 


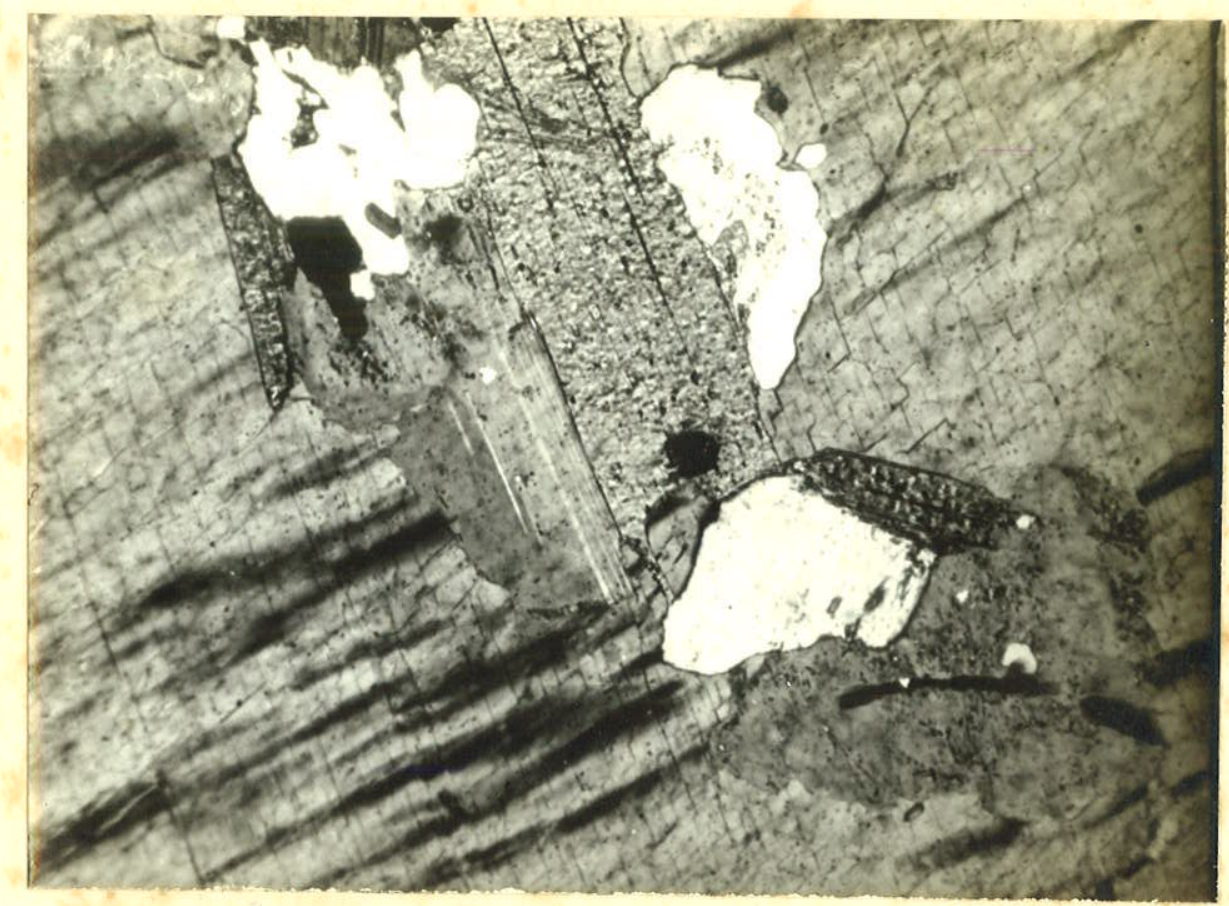

FOTOMICROGRAFIA 4 - Inclusões de quartzo, plagioclásio e biotita em fenocristal de feldspato potássico no "Granito" tipo Pirituba.

$480 \times N^{+}$. Amostra 166. Uberaba (Maciço de Caucaia). 
Os feldspatos maiores, como já foi dito, truncam e desviam a foliação da parte fina que os envolve. Com o au mento da quantidade de megacristais, a foliação se torna mais ondulada, chegando por vezes a parecer desvanecida a vista desarmada. Esses cristais maiores podem se apresentar orientados (Foto 3 ) concordantemente com a foliação ou não (Foto 4).

A biotita é, de longe, o mais importante acessório. Forma placas que se orientam, conferindo uma foliação à par te fina das rochas. Normalmente tem halos pleocróicos rela cionados com minúsculas inclusões de zircão. Em parte, está cloritizada por toda parte.

o anfibólio se apresenta em cristais subédricos anédricos, dispersos nas partes finas da rocha. Ortopiroxênio foi observado em apenas uma amostra, aparecendo ao lado de anfibólio. Epídoto, zircão, apatita, titanita e mineral opaco formam cristais de algumas micra a $1-2 \mathrm{~mm}$, euédricos ou subédricos. Moscovita fina e carbonatos em massas irregu lares aparecem com frequência. Granada foi notada em apenas uma amostra, em quantidade irrisória, sob forma de cristais subédricos, mais ou menos equidimensionais.

Os acessórios conferem cor à fração fina da rocha: quanto maior sua quantidade, mais escura.

o epídoto, além de ocorrer em grãos dispersos, forma também veios de espessura até centimétrica, cortando inclusi ve os grandes cristais de feldspato (Fotomicrografia 5).

Indícios de atuação de esforços são observados em todas as rochas do Complexo Piedade, como flexão de placas de micas e lamelas de plagioclásio, extinção ondulante de quartzo e feldspatos, geminação generalizada dos feldspatos, megacristais fraturados e segmentos separados. Williams et al. (1954) acham que tais feições são protoclásticas. Todavia, granulação de quartzo e desenvolvimento de estrutura em mol 


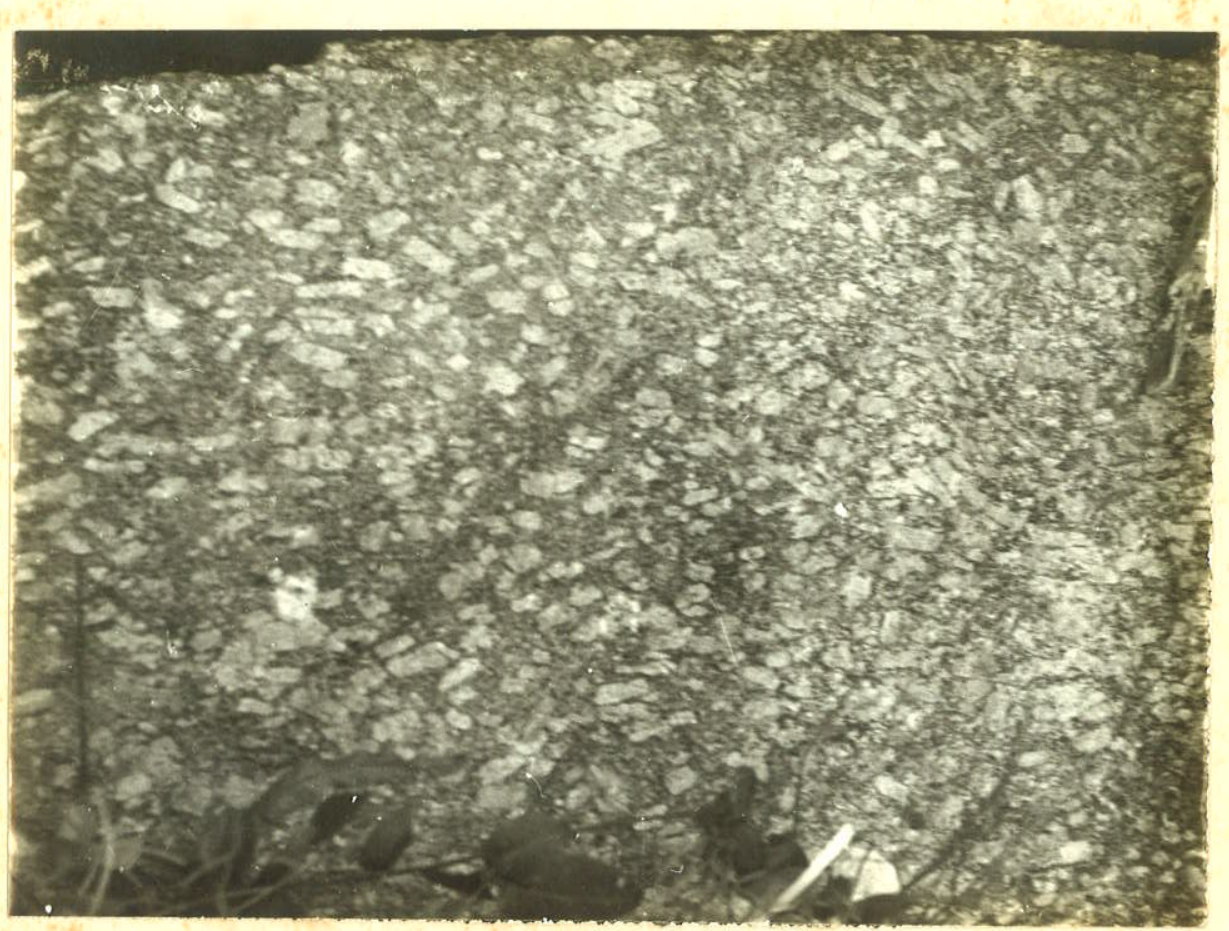

FOTO 3 - "Granito" tipo Pirituba com fenocristais de feldspato orientados. Escala 1:5. Vila Elvio. Município de Piedade. 


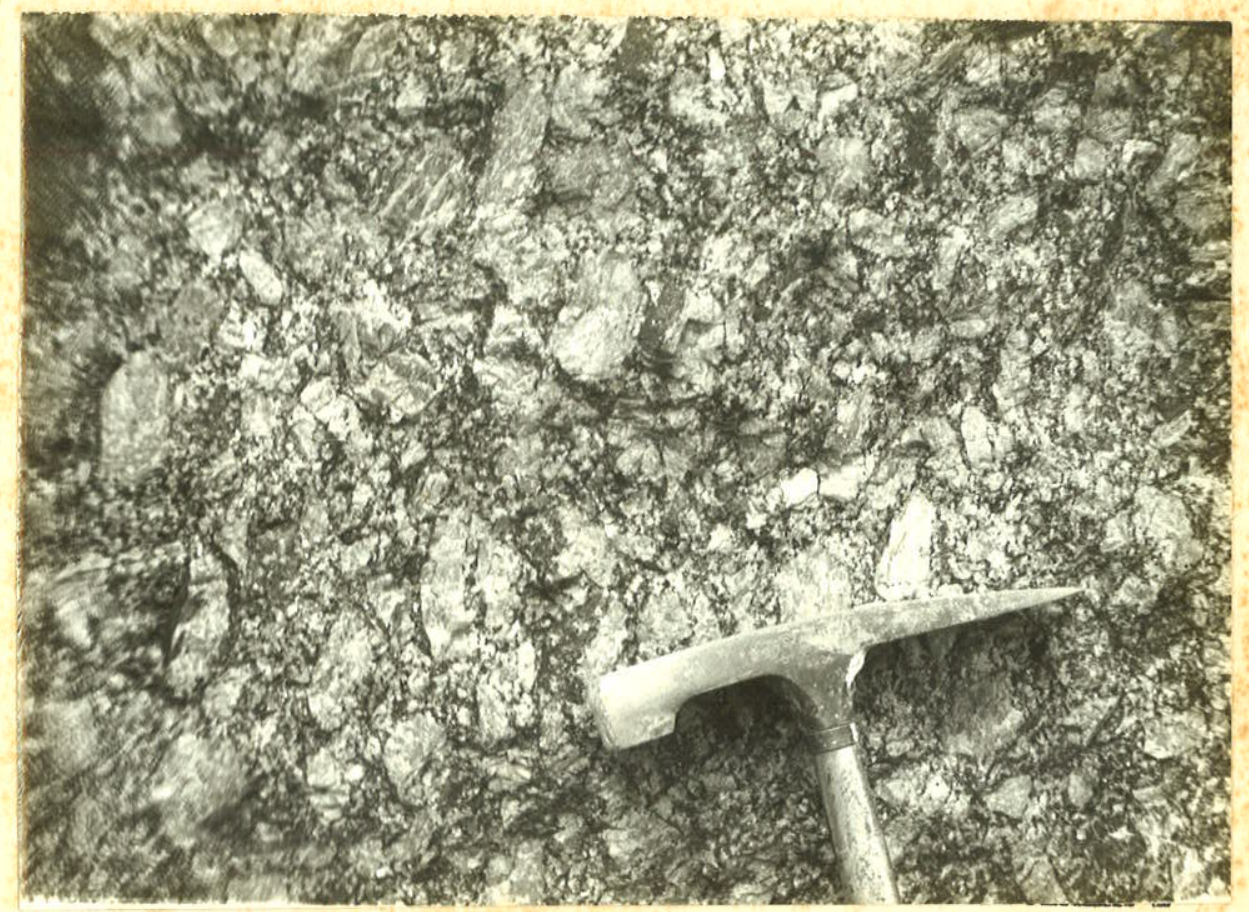

FOTO 4 - "Granito" tipo Pirituba com fenocristais de felds pato sem orientação conspícua. Vila Élvio. Municí pio de Piedade. 


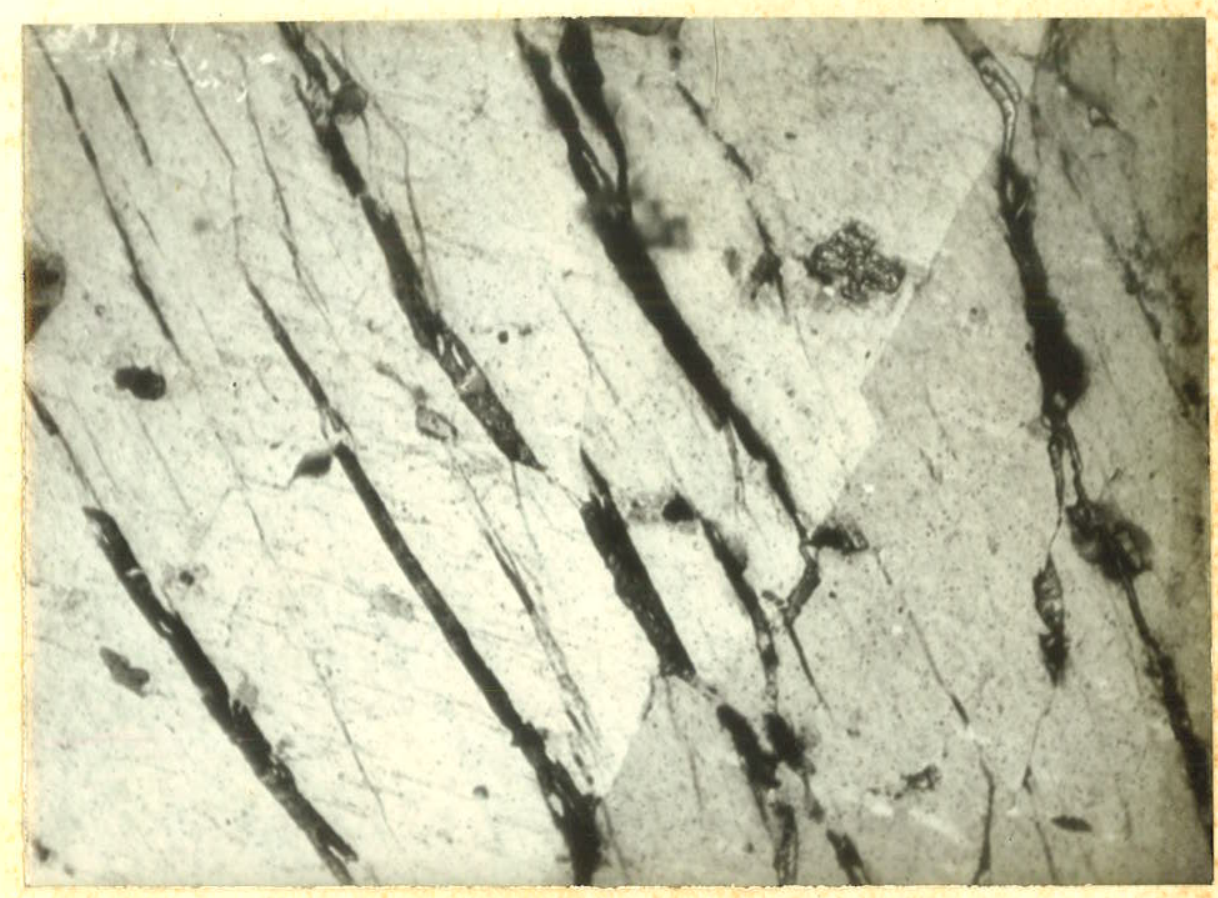

FOTOMICROGRAFIA 5 - Vênulas de epídoto ao longo de planos de clivagem de fenocristal potássico. Es te exibe geminação de Carlsbad.

$192 \times \mathrm{N}+$. Amostra $274,5.5 \mathrm{~km}$ a SSE de Alumínio, Maciço da Represa. 
dura em feldspatos, que são processos generalizados, incidi ram certamente na rocha já formada.

Tais feições cataclásticas se acentuam mais para les te, onde o Bloco Cotia se acunha gradualmente. Já na ārea da Capital paulista, Coutinho (1972) reconheceu rochas gnáis sicas com intensa cataclase e as grupou sob o nome de Faixa Gnáissica Intermediária. Franco (1956) jä descrevera os gnaisses do Butantã, que Coutinho (op. cit.) reconhece como resultante de cataclase de granjto tipo pirituba.

Os aspectos texturais e mineralógicos descritos indi cam uma história nä́o simples de evolução do Complexo Piedade e, ipso facto, dos demais corpos análogos existentes na área. Um corpo batolítico de natureza granodiorítica-adamelítica se sujeitou a um processo de feldspatização.

Essa feldspatização não foi uniforme, atingindo com intensidades diferentes, diferentes áreas, daí resultando os três tipos de granitóides que descrevemos. O fino, denunciaria proces so incipiente, o inequigranular, traduziria estágio mais avançado e o porfirítico, marcaria um estágio de máxima feldspatização: 0 que chamamos de fenocristais podem ser perfeitamente qualificados de porfiroblastos.

A metassomatose precedeu à fase hidrotermal, já que veios de epidoto cortam inclusive os cristais de microclíneo (Fotomicrografia 5). Coutinho (1053) descreveu na região de São Roque também fluorita e outros minerais associados.

Por fim, prccessos cataclésticos afetaram as rochas.

Se considerarmos as análises modais apresentadas em diagrama triangular quartzo-feldspatos-acessórjos (Figura 5), notamos um enorme hiato entre o paleossoma dos migmatitos e as rochas granitóides, o que parece tornar inviável um pro cesso de granitização de metamorfitos para gerar as rochas que se sujeitaram depois a metassomatose alcajina.

Quanto a esta metassomatose, podemos considerá-la 
Fig. 5 - DIAGRAMA QUARTZO/FELDSPATO/DEMAIS CONSTITUINTES DAS ROCHAS DO COMPLEXO PIEDADE

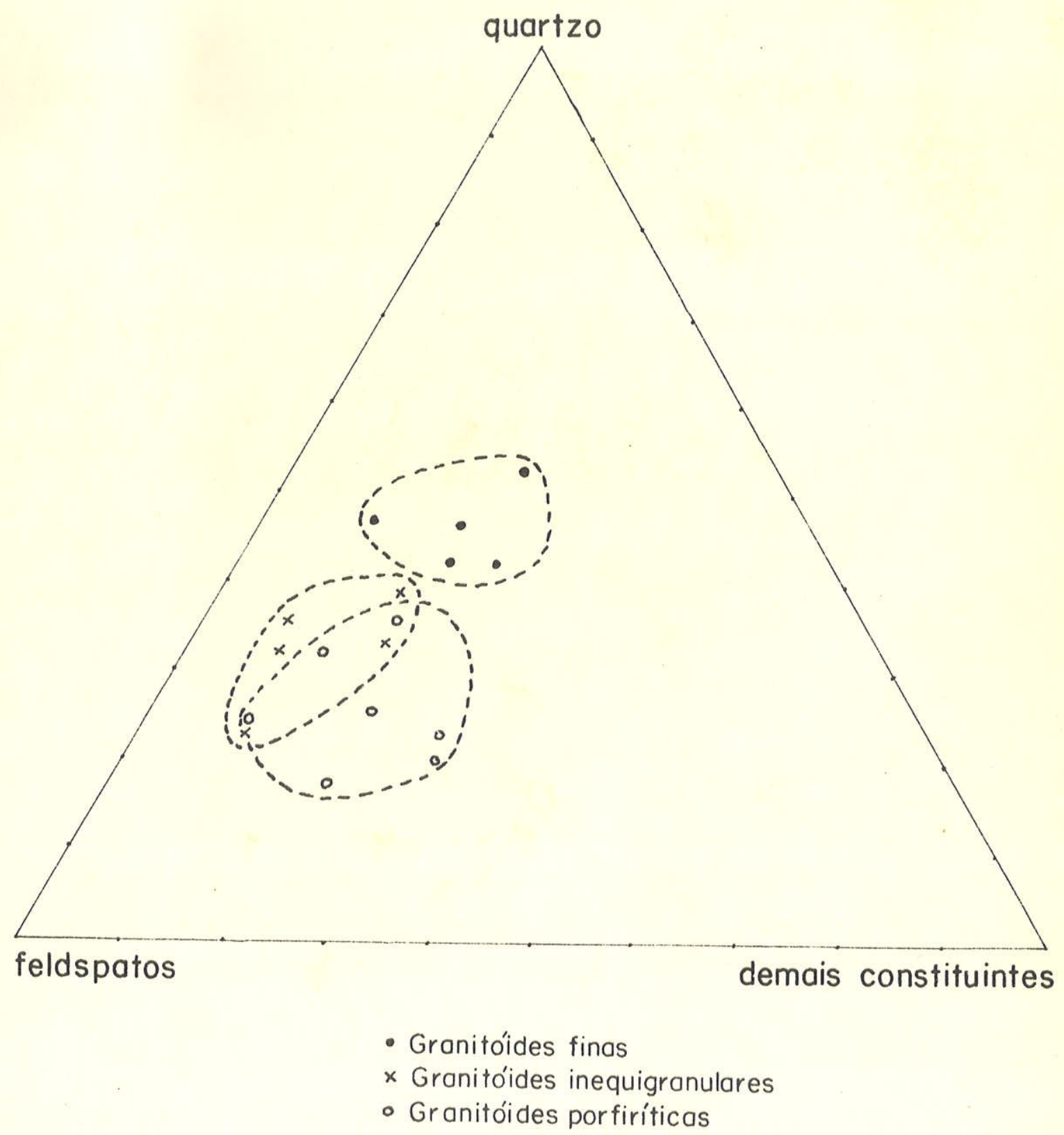


através do diagrama da Figura 6, de quartzo-plagioclásio- feldspato potássico. Parece que na passagem de granitóides finas para as ineqüigranulares há um acrëscimo notável de feldspatos potássicos e na passagem de granitóides ineqüigra nulares para as porfiríticas, o acréscimo mais importante foi de plagioclásio. Então, mobilização de $K$ e $N a$ se deram para lelamente, mas não na mesma escala, inicialmente com predomí nio do primeiro e depois com dominância do segundo. Isso se pode verificar até macroscopicamente nas rochas: as inequi granulares têm cristais de plagiociásjo menos desenvolvidos que o microcíneo; nas porfiríticos os plagioclásios apresen tam-se em maior quantidade e maiores, embora suas dimensões nunca uj.trapassem as do microcírieo.

\section{Outros corpos}

o maciço de São Miguel Árcanjo, que supomos conti nuar-se no Batólitc de Agudos Grandes (Bettencourt et al., 1971) na área do Frojeto Ribeira, tem características análo gas às descritas para o Complexo de Piedade.

Os três "stocks" graníticos de Pilar do Sul, do Tur vo e da Serra do Lopes são similares. a primeiro é intrusi vo nos epimetamorfitos e xistos a leste de Pilar do sul; o segundo penetrou na zona de contato de uma faixa de xistos com granitójdes do Complexo Pjedade, na região de Turvo, a norte de Tapiraí; o terceiro é intrusivo no Complexo Pieda de, junto ao contato com os xistos.

Constituem-se de granj.tos róseos, de granulação mé dia, com textura hipidiomórfica granular. Nenhum mineral exi be orientação preferencial. Compõe-se a rocha de quartzo, mi croclíneo pertítico e oligoclásio. o quartzo é sempre xeno morfo, com extinção ondulante sob nícois cruzados. 0 micro clíneo e o oligoclásio desenvolvem cristais subédricos e ané dricos, sem alongamento. Os acessórios principais são mosco 
Fig. 6 - DIAGRAMA QUARTZO/FELDSPATO POTA'SSICO/PLAGIOCLA'SIO DAS ROCHAS DO COMPLEXO PIEDADE

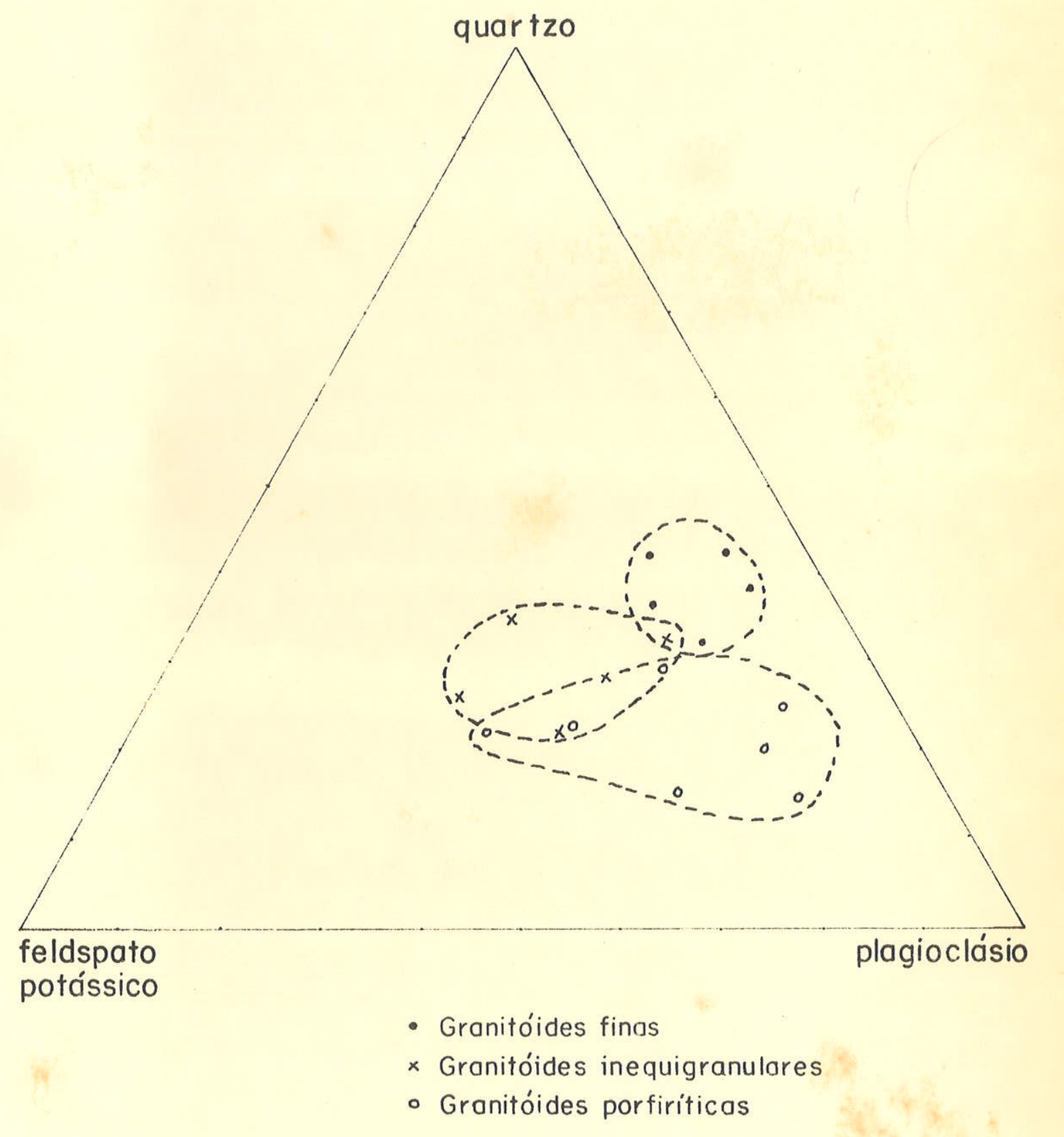


vita e biotita, esta exibindo halos pleocróicos relacionados com minúsculas inclusões de zircão. Os demais acessórios são: mineral opaco, apatita e titanita, em grãos euédricos a anédricos, de portes diminutos; carbonato, em massas xenomor fas; granada e hornblenda, em raros cristais subédricos. In tercrescimentos mirmequíticos são comuns.

Junto às bordas desses corpos aparecem ocasionalmen te rochas análogas na composição mineralógica, mas de granu lação fina e com alguma orientação das micas.

A Tabela 8 mostra algumas análises modais de amos tras desses granitos. A primeira da esquerda refere-se ao Maciço do Turvo, as três centrajs ac de pilar do sul e as duas da direita, ao da Serra do Lopes.

\section{BLOCO JUQUITIBA}

- Bloco Juquitiba é constituído de migmatitos e cor pos granitóides.

Esses migmatitos foram registrados como gnaisses e xistos (Moraes Rego, 1933; Mapa Geológico do istado de São Paulo, 1:1.000.000, 1963; Coutinho, 1972). Na realidade, po de-se reconhecer dois tipos de migmatitos: os com estrutura estromatítica e os com estrutura oftalmítica. Nos primeiros, - neossoma não se distribui uniformemente, havendo algumas zonas onde ele predomina e outras onde o inverso se dá. Eg tas últimas são as predominantes na área estudada, chegando a se observar ocasionalmente afloramentos inteiros constituí dos de paleossoma, mas que não são representáveis na escala dos mapas geológicos aqui. apresentados. As Fotos 5 e 6 mos tram migmatitos estromatiticos. 
TABELA 8

ANALISES MODAIS DE GRANITOS PÓS-TECTONICOS DO BLOCO. COTIA

\begin{tabular}{|c|c|c|c|c|c|c|}
\hline AMOSTRA $N^{\circ}$ & 219 & 145 & 217 & 235 & 141 & 236 \\
\hline NP PONTOS & 1709 & 1088 & 1147 & 1180 & 1168 & 1159 \\
\hline Quartzo & 35,8 & 21,2 & 28,2 & 27,5 & 40,7 & 40,7 \\
\hline K-feldspato & 28,3 & 48.0 & 39,5 & 35,5 & 26,7 & 23,9 \\
\hline Plagioclásio & 23,5 & 26,3 & 24,8 & 28,5 & 17,8 & 23,5 \\
\hline Biotita & 8,6 & 4,3 & 6.0 & 4,5 & 13,5 & 0,8 \\
\hline Mineral opaco & 0,3 & 0,1 & 0,2 & 2,3 & 0,3 & 0,3 \\
\hline Moscovita & 3,3 & 0,1 & 1.2 & 1,4 & 0.9 & 9,5 \\
\hline Apatita & 0,1 & tr. & $\operatorname{tr}$ & 0,2 & 0,1 & 0,4 \\
\hline Carbonato & - & - & - & - & - & - \\
\hline Titanita & 0.1 & tr. & tr. & 0,1 & - & 0,1 \\
\hline Hornblenda & - & - & . tr. & - & - & 0,8 \\
\hline Total & 100,0 & 100,0 & 100,0 & 100,0 & 200,0 & 100,0 \\
\hline
\end{tabular}

Am. 219 - Turvo, $8 \mathrm{~km}$ a $N$ de Tapiraí.

Am. 145 - $13 \mathrm{~km}$ a E de Pilar do Sul.

Am. $217-2,5 \mathrm{~km}$ a E de Pilar do sul.

Am. $235-6,5 \mathrm{~km}$ a E de Pilar do sul.

Am. 141 - $20 \mathrm{~km}$ a ENE de Pilar do Sul.

Am. 236 - $15 \mathrm{~km}$ a ENE de Pilar do Sul. 


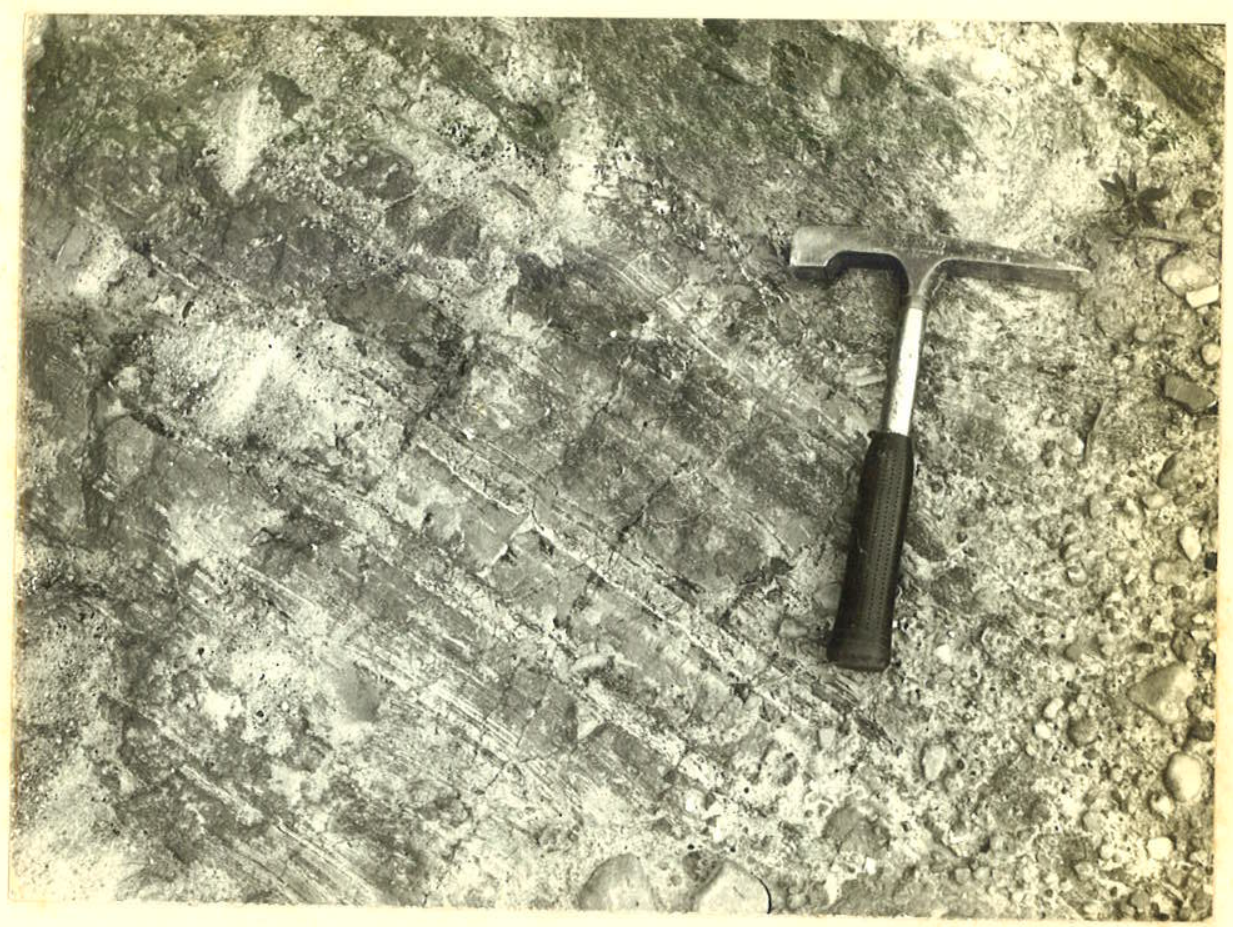

FOTO 5 - Migmatito com estrutura estromatitica. As faixas escuras säo de micaxisto e as claras de granito e pegmatito. Ribeirão dos Soares, na estrada de Juquitiba para Uberaba. 


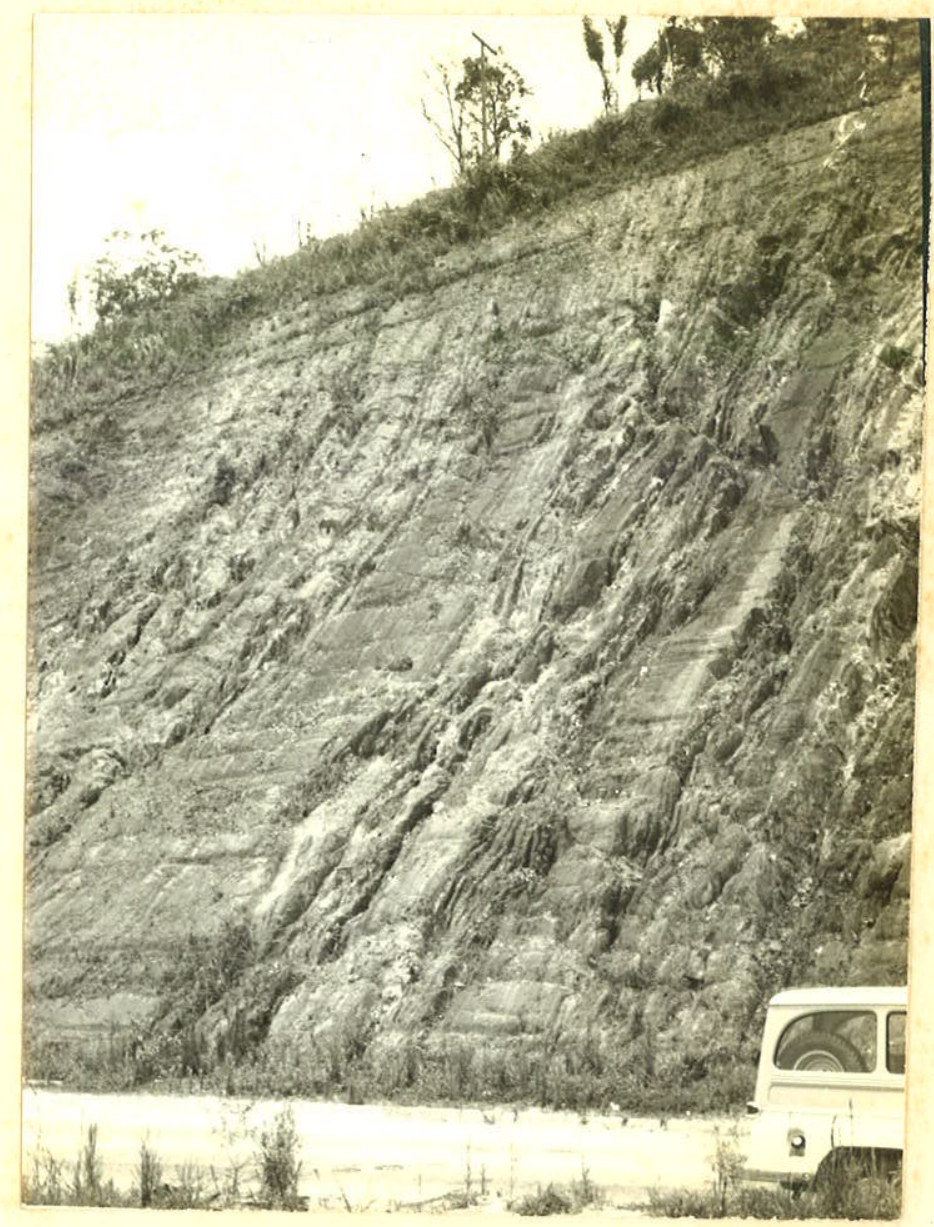

FOTO 6 - Migmatito com estrutura estromatítica.As faixas mais delgadas e salientes são de micaxisto; as mais espessas são de micaxisto feldspático a gnaisse; as mais cla ras são pegmatíticas. Corte na BR-116, $\bar{a}$ entrada de Juquitiba. 
MIGMATTOS ESTROMATITICOS

\section{Paleossoma}

o paleossoma dos migmatitos estromatíticos é de natú reza predominantemente xistosa, com granulação fina a média e cores cinza-clara a preta. Por alteração intempérica ad quire colorações avermelhadas.

A foliação é conspícua, desenvolvida pelo bandeamen to definido por faixas mais quartzosas e mais micáceas, e pe la xistosidade gerada pelas micas e por quartzo achatado.

Compõe-se o paleossoma de quartzo, biotita e moscovi ta essencialmente, com predomínio duma ou doutra, de modo a se ter micaxistos e quartzo-micaxistos. Clorita também apa rece com frequência e até em quantidades apreciáveis.

o quartzo é xenomorfo, com extinção ondulante sob nícois cruzados, de forma equidimensional ou achatada. Apre senta-se disperso entre as micas ou forma faixas ou lentícu las alinhadas segundo a xistosidade.

As micas são de duas gerações: moscovita e biotita de menor granulação desenvolvem a xistosidade e porfiroblas tos de moscovita cortam e afastam-na, ondulando-a (Fotomicro grafias 6 e 7 ). Os acessórios normais são mineral opaco e zircão. Raramente vêm-se minerais do grupo do epídoto, horn blenda e granada. Oligoclásio aparece em quantidades variá veis, chegando a teores elevados. As vezes são zonados, com bordas albíticas.

o mineral opaco e o zircão formam cristais enédricos ou subédricos, finíssimos, dispersos pela rocha. o último aparece frequentemente incluso em biotita, gerando halos pleocróicos. 


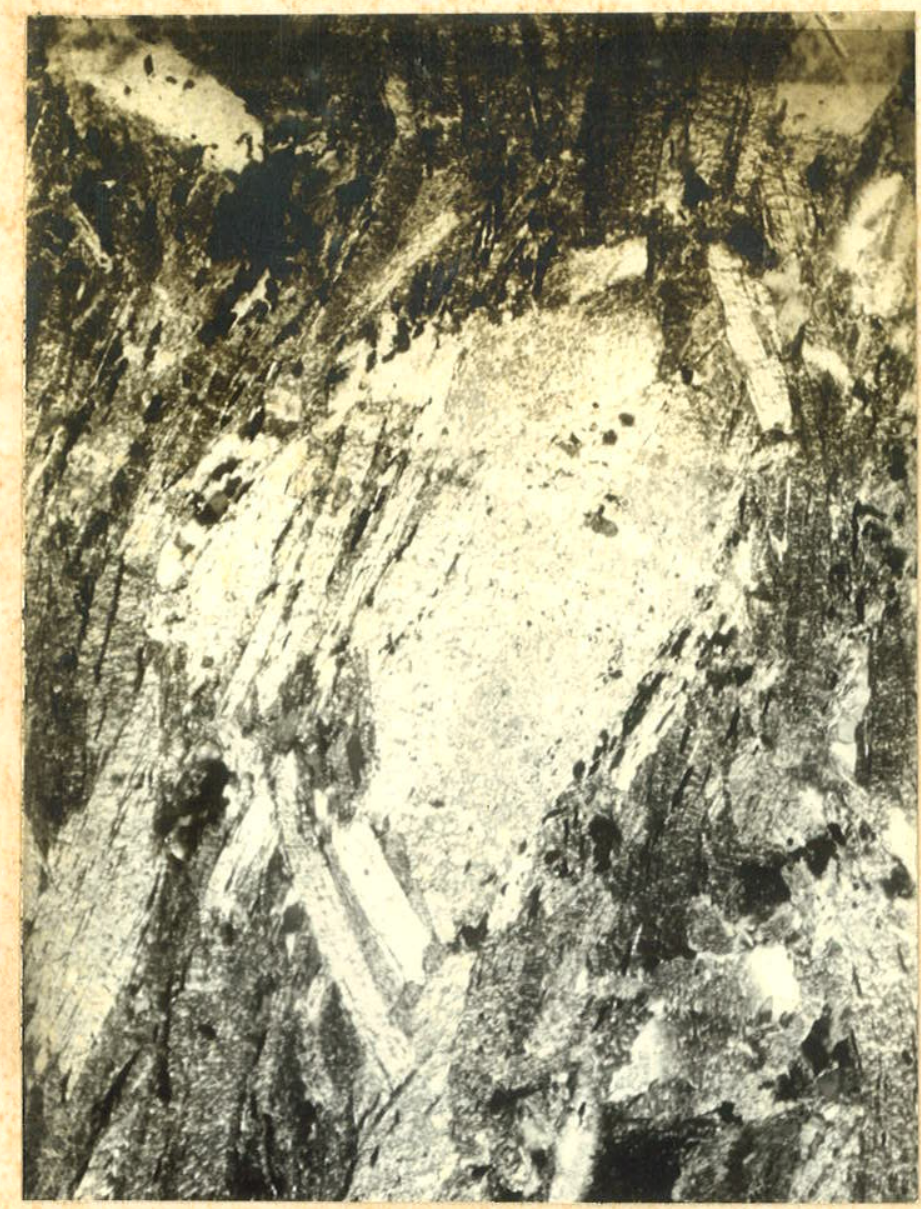

\section{FOTOMICROGRAFIA 6 - \\ Porfiroblasto de moscovita concor- dante com a xis - tosidade do mica- xisto. \\ $192 \times \mathrm{N}+$. Amostra 321. $11 \mathrm{~km}$ a $\mathrm{SW}$ de Juquitiba.}

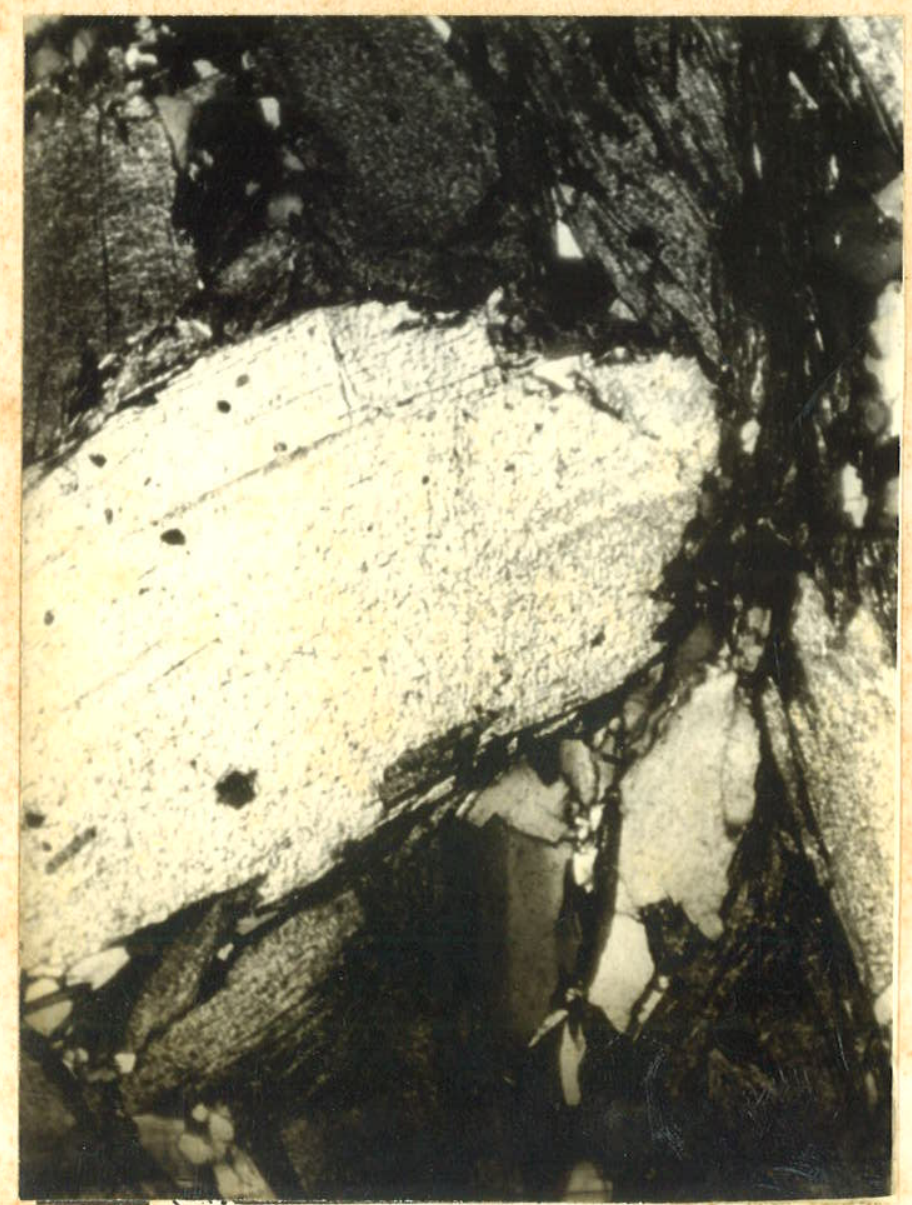

FOTOMICROGRAFIA 7 -

Porfiroblasto de moscovita discordante com a xistosidade do micaxisto. Notar trun camento parcial e desvio da xistosi dade.

192X N+. Amostra 155. $21 \mathrm{~km}$ a SSE de Ibiúna. 
Os minerais do grupo do epídoto formam agregados, parecendo resultar de saussuritização de plagioclásio. hornblenda forma pequenos prismas alinhados segundo a xisto sidade. Granada constitui porfiroblastos poiquiloblásticos, englobando grãos de quartzo. o plagioclásio, quando em quan tidades irrisórias, apresenta-se em grãos xenomorfos disper sos; quando em teores elevados, aumentam em tamanho, tornam- se subédricos e constituem porfiroblastos poiquiloblásticos, incluindo grãos de quartzo e micas. A sua quantidade pode ultrapassar $25 \%$, com o que a rocha deve ser qualificada de gnaisse.

Turmalina, apatita e pirita, em cristais subédricos e euédricos se desenvolvem nas proximidades de corpos graní ticos, atestando ação de fluidos pneumatolíticos.

Vez ou outra nota-se a presença de mica (sericita), comparáveis à que Coutinho (1972) na área de são Paulo mos trou derivar de alteração de sillimanita.

A Tabela 9 apresenta análises modais de materiais me tapeliticos. As trés colunas da esquerda referem-se a mica xistos; a quarta a quartzo-micaxisto e a última a gnaisse.

\section{Quartzitos}

De permejo com os xistos, aparecem camadas de espes suras milimétricas a decamétricas de quartzitos feldspáticos de dois tipos.

o primeiro tipo é branco ou cinza-claro, tingindo-se de tons amarronzados com a alteração intempérica, e dotada de granulação de fina a média. Constituem-se de quartzo e feldspato, essencialmente. Os acessórios são: biotita, mos covita, minerais do grupo do epidoto, titanita, apatita, zir cão e mineral opaco, perfazendo quantidades irrisórias, como se pode ver pela análise modal apresentada na Tabela 10. 
TABELA 9

ANALISES MODAIS DE XISTOS DO BLOCO JUQUITIBA

\begin{tabular}{|c|c|c|c|c|}
\hline AMOSTRA $\quad N^{8}$ & 178 & 318 & 348 & 320 \\
\hline$N^{8}$ PONTOS & 1137 & 1513 & 1276 & 1123 \\
\hline Quartzo & 28,8 & 16,2 & 16,4 & 45,2 \\
\hline Biotita & 15.4 & 34.9 & 29.5 & 10,1 \\
\hline Moscovita & 33,3 & 48,0 & 53,6 & 43,4 \\
\hline Clorita & 11,8 & - & - & - \\
\hline Mineral opaco & 1,0 & 0.9 & 0,4 & 0,8 \\
\hline Grupo do epídoto & 5,3 & - & - & - \\
\hline Hornblenda & 4,1 & - & - & - \\
\hline Granada & 0,2 & - & - & - \\
\hline Zircão & 0,1 & tr. & tr. & $\operatorname{tr}$ \\
\hline Turmalina & - & - & 0,1 & 0,5 \\
\hline Plagioclásio & - & $\operatorname{tr}$ & - & $\operatorname{tr}$ \\
\hline Apatita & tr. & - & - & tr. \\
\hline
\end{tabular}

Am. $178-5,5 \mathrm{~km}$ a SW de Uberaba.

Am. 318 - $1 \mathrm{~km}$ a SE de Juquitiba.

Am. $348-7,5 \mathrm{~km}$ a ENE de Juquitiba.

Am. 320 - $11 \mathrm{~km}$ a SW de Juquitiba.

Am. 364 - $2 \mathrm{~km}$ a NE de Uberaba. 
TABELA $\quad 10$

ANÁLISE MODAL DE QUARTZITO FELDSPÄTICO

$\begin{array}{lr}\text { AMOSTRA No } & 319 \\ \text { Ne PONTOS } & 1010 \\ \text { Quartzo } & 78,0 \\ \text { Plagioclásio } & 19,6 \\ \text { Biotita } & 1,5 \\ \text { Mineral opaco } & 0,6 \\ \text { Grupo do epídoto } & 0,2 \\ \text { Titanita } & 0,1 \\ \text { Apatita } & \mathrm{pr} . \\ \text { Moscovita } & \mathrm{pr} . \\ \text { Zircão } & \mathrm{pr} .\end{array}$

Am. 319 - 11 km a SW de Juquitiba.

o quartzo é xenoblástico, com extinção ondulante a nícois cruzados. Forma um mosaico granoblästico, mas às ve zes os grãos são achatados, desenvolvendo uma foliação. Os feldspatos presentes são oligoclásio e, raramente, microclíneo; formam grãos xenomorfos, de dimensões análogas aos de quartzo. A biotita dispõe-se orientadamente, conferindo fo liação à rocha. Os demais acessórios aparecem aqui e ali em pequenos grãos, subédricos ou anédricos.

O segundo tipo pode ser denominado quartzito calco- silicático. Tem granulação fina, textura maciça, cores cin za esverdeadas que, por alteração intempérica, passam a ver melhas. Compõe-se de quartzo, hornblenda, minerais do grupo do epídoto, diopsídio, titanita, granada, apatita e, com in cidência restrita, carbonato, zircão, biotita, mineral opaco, clorita, moscovita, feldspato potásico e turmalina. A Tabe la 11 mostra análises modais de tais rochas.

o quartzo é xenomorfo, com extinção ondulante a ní cois cruzados, equidimensional ou achatado, neste caso desen 
TABELA 11

ANALISES MODAIS DE QUARTZITOS CALCO-SILICATICOS

\begin{tabular}{|c|c|c|c|}
\hline AMOSTRA $\quad N^{8}$ & 328 & 338 & 363 \\
\hline N P PONTOS & 1220 & 1107 & 1026 \\
\hline Quartzo & 54.1 & 71,5 & 53,3 \\
\hline Plagioclásio & 23,4 & 10.4 & 11,0 \\
\hline Grupo do epídoto & 6.6 & 0,7 & 15,3 \\
\hline Diopsídio & 0,2 & - & 0,9 \\
\hline Hornblenda & 6.4 & 0.2 & 6,8 \\
\hline Titanita & 1,6 & 1,1 & 1,3 \\
\hline Granada & 7,3 & 1.0 & 1,1 \\
\hline Apatita & 0,1 & 0,3 & 0,2 \\
\hline Carbonato & 0,2 & $\mathrm{pr}$ & 0,1 \\
\hline Zircão & - & pr. & - \\
\hline Biotita & - & 4,0 & - \\
\hline Mineral opaco & pr. & 0,1 & pr. \\
\hline Clorita & - & 2,3 & - \\
\hline Moscovita & - & 8,4 & - \\
\hline Microclíneo & 0.2 & - & - \\
\hline Am. $328-9 \mathrm{~km}$ a SE de & Juquitiba. & & \\
\hline $\begin{aligned} \text { Am. } 338- & 13 \mathrm{~km} a \mathrm{~W} d \mathrm{e} \\
& \text { Fumaça. }\end{aligned}$ & Juquitiba. & vertedouro da Barragem & $d a$ \\
\hline
\end{tabular}


volvendo foliação. O plagioclásio é subédrico ou anédrico e de composição na faixa andesina-labradorita. Mostra-se às vezes saussuritizado e em outras ocasiões intensamente seri citizado. Está sempre geminado segundo as leis da Albita ou Albita-Periclíneo. Intercrescimentos mirmequíticos são vis tos esparsamente.

A hornblenda forma cristois subédricos e anédricos, às vezes geminados e frequentemente poiquiloblästicos, in cluindo grãos de quartzo e plagioclásio. Vez ou outra tém hábito fibroso. Os minerais do grupo do epidoto formam grãos minúsculos, agregados em massas e talvez formados por saus suritização de plagioclásio.

A titanita, apatita, zircão e mineral opaco, consti tuem cristais euédricos e subédricos, minúsculos e dispersos na rocha.

A biotita e clorita se apresentam em placas orienta das, desenvolvendo uma foliação perceptível ao microscópio. As vezes concentram-se em faixas de espessura milimétrica ou centimétrica e cores cinza escura, provavelmente refletindo a antiga estratificação do sedimento.

o feldspato potássico é microclíneo pertítico, exí bindo geminação em grade, e sua incidência é esporádica. Cár bonato forma pequenas massas xenomorfas dispersas. Granadas se desenvolvem euédrica ou subédricamente, às vezes concen trando-se em pontos e dando à rocha aspecto maculado com man chas submilimétricas avermelhadas. É frequentemente micro poiquiloblástica, incluindo quartzo, plagioclásio, titanita e às vezes biotita. Turmalina é ráríssima e limita seu apa recimento às adjacências de corpos granitóides.

Rochas similares a essas foram descritas por Cout $\underline{i}$ nho (1972) na região da Represa de Guarapiranga, considerando-as como metaconcreções. Ellert (1961) reconheceu-as em seixos de um metaconglomerado em São Bernardo do Campo. 
A quantidade de feldspatos varia muito, como se vê na Tabela ll. Por vezes o limite de $25 \%$ é superado, deven do-se então qualificar a rocha como gnaisse. Uma análise mo dal de gnaisse é dada na Tabela 12.

Por outro lado, também camadas com baixas porcenta gens de quartzo ocorrem. Qualificâmo-las como rochas calco-silicatadas. A Tabela 13 mostra três análises modais em tal tipo litológico. São rochas anômalamente ricas em titanita e os feldspatos por vezes superam o nível de $25 \%$.

\section{Metabasitos}

Corpos de metabasitos aparecem ocasionalmente no Blo co Juquitiba, com dimensões muito reduzidas para serem carto grafados na escala de 1:100.000.

A norte de Juquitiba expõe-se um corpo de metagabro. A rocha tem granulação média, textura maciça e cor verde es cura. Compõe-se de plagioclásio e ferromagnesianos, essen cialmente, numa trama blastointergranular. o plagioclásio se apresenta em cristais alongados, subédricos, sem orienta ção preferencial. É labradorítico, mas está quase totalmen te saussuritizado. Os ferromagnesianos são augita, hornblen da, biotita e clorita. A augita forma cristais com envoltórios de hornblenda. A biotita e a clorita estão associadas, às vezes vendo-se a primeira envolvendo parcialmente os cris tais de augita-hornblenda. Quartzo, em grãos xenomorfos e intersticiais, mineral opaco e apatita, estes em cristais fi nos, euédricos ou subédricos, dispersos, são os acessórios.

No vale do rio Juquiá, pouco a sul do limite da Fo Iha de São Roque, a $18 \mathrm{~km}$ SW de Juquitiba, observa-se um cor po de anfibolito concordante com a foliação dos xistos cir cundantes. A rocha tem granulação fina a média, cor preta e textura nematoblástica. Os constituintes essenciais são hornblenda e plagioclásio. A hornblenda forma prismas sub 
TABELA 12

ANALISE MODAL DE GNAISSE CALCO-SILICATIICOS

$\begin{array}{lr}\text { AMOSTRA N8 } & 342 \\ \text { No Pontos } & 1035 \\ \text { Quartzo } & 50,6 \\ \text { Plagioclásio } & 34,2 \\ \text { Grupo do epídoto } & 1,7 \\ \text { Diopsídio } & 0,1 \\ \text { Titanita } & 1,3 \\ \text { Granada } & 3,0 \\ \text { Apatita } & 0,2 \\ \text { Carbonato } & p r, \\ \text { Zircão } & 0,1 \\ \text { Biotita } & 0,1 \\ \text { Hornblenda } & 8,5 \\ \text { Turmalina } & 0,2\end{array}$

Am. 342 - $19 \mathrm{~km}$ a WSW de Juquitiba. 
TABELA 13

ANALISES MODAIS DE MICAXISTOS (PALEOSSOMA)

\begin{tabular}{|c|c|c|c|}
\hline AMOSTRA $\quad N^{\circ}$ & 170 & 171 & 172 \\
\hline N\& PONTOS & 1109 & 1036 & 1104 \\
\hline Quartzo & 26.4 & 18,4 & 23,3 \\
\hline Plagioclásio & 16.0 & 13,0 & 9,4 \\
\hline Microclíneo & 9,6 & 6,6 & 5,4 \\
\hline Grupo do epídoto & 4,3 & 13,3 & 11,0 \\
\hline Diopsídio & 9,6 & 10,1 & 4,5 \\
\hline Hornblenda & 12,7 & 6.7 & 11,1 \\
\hline Titanita & 19,3 & 26,0 & 33.5 \\
\hline Granada & 1,2 & 1.9 & 0,9 \\
\hline Carbonato & 0,3 & 0,3 & 0,8 \\
\hline Zircão & pr. & 3,0 & $\mathrm{pr}$. \\
\hline Biotita & pr. & - & - \\
\hline Mineral opaco & pr. & $\mathrm{pr}$. & pr. \\
\hline Turmalina & - & - & pr. \\
\hline Clorita & 0,6 & pr. & pr. \\
\hline Moscovita & - & 0.2 & 0,1 \\
\hline
\end{tabular}

Am. 170 - $11 \mathrm{~km}$ a S de Caucaia do Alto.

Am. 171 - $11 \mathrm{~km}$ a S de Caucaia do Alto.

Am. 172 - $11 \mathrm{~km}$ a S de Caucaia do Alto. 
édricos, frequentemente poiquiloblásticos contendo inclusões de quartzo, plagioclásio, titanita e mineral opaco. 0 pla gioclásio é andesina cálcica, constituíndo grãos mais ou mé nos equidimensionais, subédricos ou anédricos, dispersos en tre os cristajs de anfibólio. Os acessórios são quartzo, ti tanita, apatita e mineral opaco. O quartzo aparece em por centagens muito baixas, com grãos pequeninos ocupando inter tícios. Os demais acessórios formam cristais euédricos ou subédricos, minúsculos, dispersos pela rocha.

Um terceiro tipo de metabasito tem representação no Bloco Juquitiba. Trata-se de clorita-xistos, como os expos tos em cortes da BR-116 a E da Capela das Laranjeiras, já fo ra da Folha São Roque. São rochas de granulação fina, com foliação conspícua e cor verde-parda, passando a verde-amare lada e a vermelha com a alteração intempérica. Compõem-se de clorita, actinolita-tremolita, mineral opaco,biotita, apa tita e quartzo. A clorita se apresenta em placas,orientadas ou suborientadas, desenvolvendo a xistosidade. 0 anfibólio constitui cristais subédricos e anédricos, dispersos pela ro cha e suborientados em conformidade com a foliação da rocha. A biotita aparece associada à clorita. Mineral opaco e apa tita constituem pequeninos cristais euédricos ou subédricos, dispersos entre os cristais maiores. O quartzo é xenomorfo, com extinção ondulante sob nícois cruzados, formando frequen temente agregados lenticulares alongados segundo a foliação da rocha. Acessórios ocasionais são titanita e minerais do grupo do epídoto.

\section{MIGMATITOS OFTALMITICOS}

Esses migmatitos formam faixas lenticulares alonga das segundo a orientação geral das dobras. Correspondem a embrechitos ocelares de Jung e Roques (1952).

A rocha tem aspecto homogêneo, constituindo-se essen 
cialmente de quartzo e feldspatos. o quartzo é xenomorfo, equidimensional ou achatado, neste caso desenvolvendo folia ção. Exibe sempre extinção ondulante a nícois cruzados e uma parte tem dimensões menores, ocupondo posições intersticiais.

Os feldspatos presentes são oligocläsio e microclí neo pertítico. Ambos são subédricos ou xenomorfos. As di mensões variam muito: em parte, juntamente com o quartzo, constituem uma massa mais ou menos equigranular, enquanto ou tra parte assume tamanhos mais avantajados, conferindo à ró cha uma textura ineqüigranular seriada. Estes cristais maio res são normalmente poiquiloblásticos, incluindo grãos de quartzo e micas; o microclíneo contém, adicionalmente, inclu sões de plagioclásio. Suas dimensões podem chegar a $1-2 \bar{x}$ 2-3 cm, e as seções nos afloramentos são subretangulares e eliticas.

Os acessórios são biotita, moscovita, apatita, tita nita, mineral opaco, zircão e mais raramente clorita. Ocasió nalmente, aparecem minerais do grupo do epídoto, hornblenda, granada, turmalina e carbonato.

As micas integram a parte fina dia rocha e conferem à rocha uma xistosidade proeminente. Apatita, titanita,zircão e mineral opaco formam microcristais subëdricos e anédricos, sobretudo em associação com biotita. Os minerais do grupo do epídoto formam agregados finos locais, talvez por resul tarem de saussuritização de plagioclásio. A hornblenda é subédrica e aparece ao lado da biotita. A granada quando presente, é porfiroblástica, com contornos subédricos e tex tura poiquilitica. As inclusões são de quartzo e micas, às vezes em arranjo helicitico, mostrando que o crescimento se deu em parte em conjunção com uma fase dinâmica. Em geral, porém, essas inclusões estão dispostas em concordância com a foliação à volta, denunciando crescimento em condjções de calma tectônica.

A turmalina forma cristais idiomorfos, dispersos na 
rocha, com pequenas dimensões. O carbonato constitui massas xenomorfas, associadas aos minerais do grupo do epídoto.

A Tabela 14 mostra análises modais de cinco amostras de migmatitos oftalmíticos, selecionadas de modo a represen tar um corte transversal, do centro para a borda de um corpo. Assim, da esquerda para a direita, a granulação diminui de mëdia a fina e a quantidade e tamanho de feldspatos macrosco picamente distinguiveis diminuem, ao mesmo tempo em que as quantidades de (quartzo + micas) aumentam. Nas amostras de granulação mais fina, observa-se que os feldspatos se desen volveram em zonas onde o quartzo está mais granulado, suge rindo que a feldspatização foi precedida de um preparo textu ral da rocha.

Nesses migmatitos encontram-se com frequência lâmi nas e camadas de quartzito micáceo paralelas à foliação dos oftalmitos. Essa feição não só atesta a origem metassedimen tar do paleossoma, como mostra o paralelismo da xistosidade com a antiga estratificação.

Esses migmatitos oftalmíticos, apresentando transi ções para os migmatitos estromatíticos, acham-se melhor de senvolvidos a leste da Folha de São Roque (Y. Hasui, G.R. Sadowski, G.F. Fuck, O.R. Obata e C.R. Carneiro, inédito). Seus limites representados no mapa geológico anexo (Folha de São Roquel correspondem ao aparecimento de porfiroblastos de feldspatos visiveis macroscopicamente.

\section{ROCHAS GRANITÓIDES}

Vários corpos granitóides existem no Bloco Juquitiba, conforme mostra a Figura 4. Os maciços de Jarupará e de Cau caia acham-se truncados pelo Falhamento de Caucaia.

Todos eles são petrograficamente heterogêneos,perfei. tamente equiparáveis ao complexo Piedade. Assim é que ro chas granitóides porfiriticas, ineqüigranulares e finas es 
TABELA 14

ANÁLISES MODAIS DE MIGMATITOS OFTALMITICOS

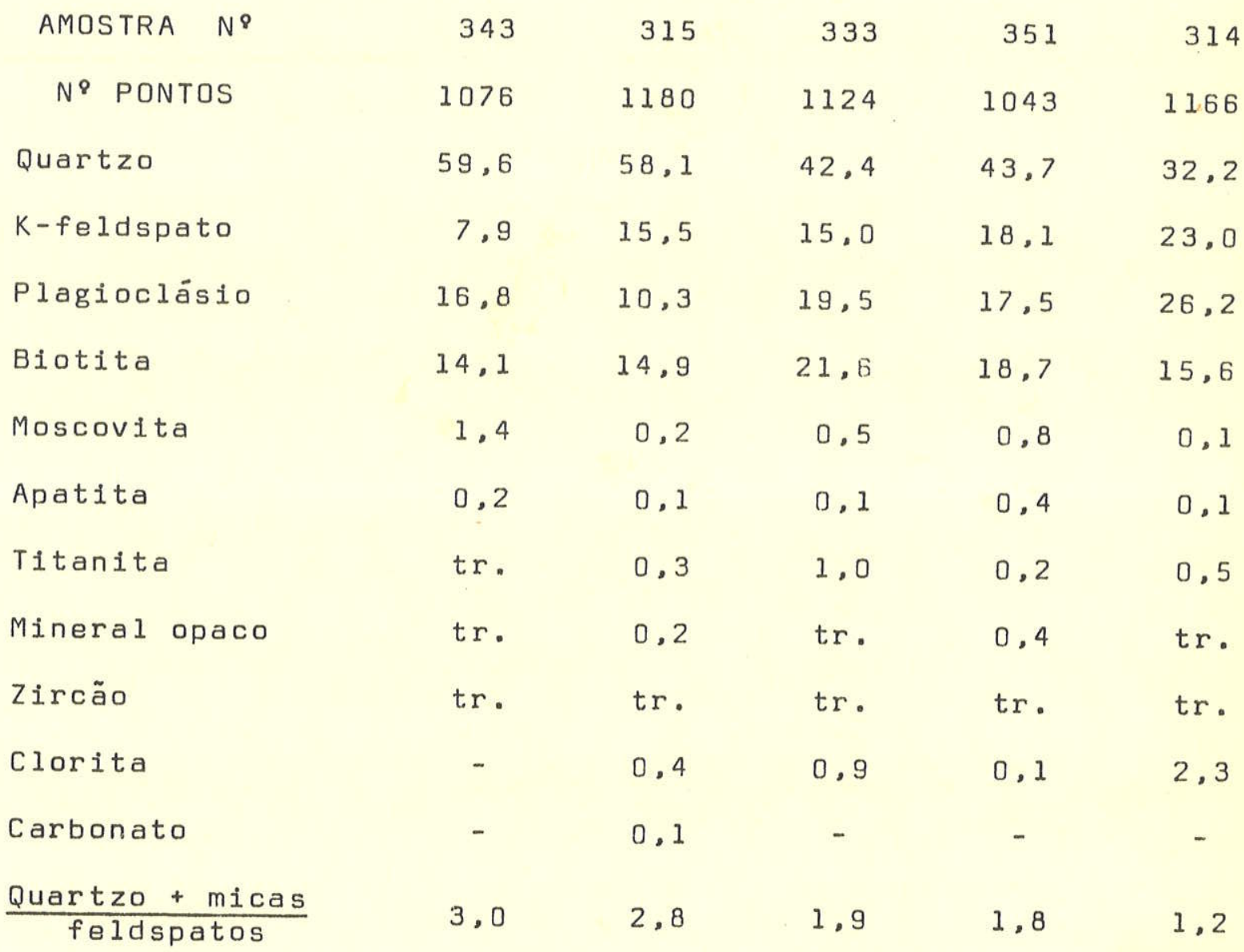

As amostras 343, 315, 333, 351 e 314 provêm do corpo de migma tito oftalmítico de São Lourenço, a NE de Juquití ba, pouco a E do limite da folha de São Roque. 
tão presentes em todos. Observa-se que as rochas granitói des finas predominam e, no campo, chegam a lembrar anatexitos embrechíticos (granito-gnaisses). Todavia, as passagens pa ra tipos inequigranulares e porfiriticos, a falta de passa gens graduais para as encaixantes e as discordancias par ciais dos contatos são indicativos do caráter intrusivo dos corpos granitóides.

\section{BACIA DO PARANA}

A Bacia do Paraná se estende até a Folha de Pilar do Sul e o canto noroeste da Folha de São Roque, representada pelo Grupo Tubarão e pela Formação Irati. Não sendo objeti vo deste estudo sua descrição, eximimo-nos de maiores consi derações.

o Grupo Tubarão, de idade permo-carbonífera, se cons titui de sedimentos glaciais e correlatos, dos quais um tra to completo, da base ao topo, se acha presente na folha de Pilar do sul. Petrograficamente, tem-se arenitos grossos a conglomeráticos, fejdspáticos, argilosos e siltosos; silti tos e folhelhos; diamictitos e conglomerados. Um excelente apanhado geral dessa unidade estratigráfica foi feito por Rocha-Campos (1967).

A Formação Irati, de idade permiana, comparece nos arredores de Itapetininga, no canto noroeste da Folha de Pi lar do sul. Folhelhos negros, por vezes pirobetuminosos, ar gilitos, siltitos e arenitos finos são os termos litológicos presentes. Essa unidade foi pormenorizadamente estudada por Amaral (1971).

\section{MAGMÃT I CAS MESOZÓICAS}

As ocorrencias de rochas alcalinas em Piedade foram noticiadas por Knecht (1960) e por Felicissimo Jr. (1968). 
Na margem norte do rio Sarapuí, há uma intrusão elí tica de $850 \times 300 \mathrm{~m}$, alongada segundo EW e encaixada no Com plexo Piedade. Constitui-se de sienito, mas na superfície só se observam produtos de alteração, contendo magnetita, ba rita e apatita. Felicissimo $J x$. (1968) acha possivel a exis tência de carbonatito associado.

Pouco a oeste dessa ocorrência, um dique de shonkini to pórfiro corta as rochas granitóides do Complexo Piedade (G.C.Melcher, comunicacão pessoal).

Amostras desse shonkinito foram datadas pelo método potássio-argônio (Amaral et al., 1966) fornecendo idades atri buíveis ao fim do Jurássico/início do Cretáceo.

Entre a extremidade nordeste da faixa de rochas cal cárias de Santa Helena e a Serra cle Inhaíba, a SSW de Briga deiro Tobias, um pequeno dique de diabásio perietrou nas ro chas epimetamórficas (J.S. Bettercourt, comunicąão pessoal). Aparentemente, ele se relaciona com o magmatismo básico que afetou a zona do Arco de Ponta Grossa, atravéc de injeção de diques de diabásio. Tal manifestação magmática foi datada por Amaral et al. (1966), como tendo se processado em tem pos juro-cretécicos.

\section{SEDTMENTOS TERCIARIOS E QUATERNARIOS}

Várias ocorrências de sedimentos terciários foram en contradas, todas em encostas de elevações, ora em franca ero são. As espessuras são restritas, não ultrapassando duas dé zenas de metros.

Constituem-se de camadas de argila e argila siltosa, geralmente com uma faixa de cascalho arenoso na base. Somen te na ocorrência de Caucaia do Alto notamos a predominância de termos grosseiros: cascalho arenoso e areias, ricas em fragmentos de granjto, feldspatos e micas. Crostas e concre ções limoníticas são comuns nos níveis superiores. 
A idade terciária (pliocênica ?) tem sido atribuída a esses sedimentos. Lembramos, todavia, que não há unanimi dade de opiniões. Mendes (1950) observando o volume, exten são e inconsistência dos sedimentos, julgou-os compativeis com idade quaternária. Na falta de elementos que permitam uma datação das camadas, preferimos manter aqui a idade ter ciāria.

Os sedimentos quaternärios aparecem en várzeas e ala gadiços associados aos vales atuais. Constituem-se de areia, silte, argila, cascalho e turfa. As espessuras são discre tas, provavelmente não ultrapassando uma vintena de metros.

As äreas de maior expressão de sedimentos quaterná rios são os vales do rio Itapetininga e do rio sorocaba. 0 processo de sedimentação relacionou-se com a existência de litologias com erodibilidades diferentes. Um curso d'água escavando rochas mais erodíveis, do encontrar corpos mais re sistenties à erosão, tende a alargar o seu vale e a se repre sar a montante onde incidirá, pela mudança de velocidade de fluxo, um processo de sedimentação.

No rio Sorocaba, o corpo granitóide de São Francisco constituiu uma barreira, em função da qual se deu intensa se dimentação a sudeste. A Represa de Ituparanga ali implantada alagou parte da planície aluvial, a qual se expõe agora de Ibiuna para montante, nos vales dos formadores do rio so rocaba (Sorocá-Mirim, Sorocá-Buçu e seus afluentes). Os cur sos d'água meandram na planície, isolando grande número de braços mortos.

De maneira análoga, o rio Itapetininga se desenvolve sobre a área do Grupo Tubarẽo e, ao alcançar a Formação Ira ti, na região de Itapetininga, encontra uma barreira. Dai a intensa sedimentação para leste, constituindo-se ampla planí cie aluvial sobre a qual o rio divaga.

Em outros cursos menores observam-se aluviões descon tínuos, certamente vinculáveis com diferenças litológicas no 
trajeto. Um caso evidente é dado pela Água da Batéia, afluen te do rio Turvo, a norte de Tapiraí. O seu vale se desenvol ve sobre migmatitos estromatiticos com paleossoma dominante junto ao contato com rochas granitóides do Complexo Piedade. o rio Turvo recebe esse afluente para em seguida cruzar a zo na de contato. Nessa região, no vale do rio Turvo e da Água da Batéia houve sedimentação localizada. Outro caso se vê no córrego Varjão, a nordeste de Alumínio, em relação ao qual a barreira foi constituída por um pacote de quartzitos.

Casos análogos foram assinalados por Hasui et al. (1969) em relação ao rio Jundiaí, que percorre uma zona de migmatitos e atravessa o batólito granitico de Itu em Itupe va, invadindo em seguida a área do Grupo Tubarão na região de Itaici e desviando o seu curso para sudoeste rumo a Sal. to de Itu, onde reencontra o Granito de Itu. A montante de Itupeva observa-se larga e extensa planície aluvial. 0 mes mo acontece entre Salto de Itu e Itaici. Outro exemplo notá vel é dado pelo rio Tietê, que percorre a zone do Falhamento de Taxaquara até Barueri, onde sofre inflexão dirigindo-se para NW, através do batólito granítico de Itaqui. A montan te de Barueri desenvolveu-se a enorme planicie aluvial, à qual se relacionam as inundações ne área da Capital paulista.

Na Figura 7 acham-se representadas as ocorrências de sedimentos terciários da área em pauta. É notável a associa ção delas com os vales atuais (rio Sorocaba, rio são joão e rio Turvol. Aparentemente o mesmo mecanismo acima pode ria ter controlado a deposição desses sedimentos e não vemos nenhuma razão para impugná-10.

Por outro lado, Freitas (1951), Almeida (1955), Hennies et al. (1969) e Coutinho (1972) consideran que a sedimentação, destacadamente na Bacia de São Paulo, teve conexão com movi mentos de blocos, por reativações de falhamentos antigos. Fei ções notavelmente sugestivas foram mostradas para apoiar é sa idéia. Na área em foco, igualmente, nota-se que na parté 
nordeste da Figura 7 há várias ocorrências situadas sobre os Falhamentos de Caucaia e Taxaquara e no Bloco por eles limi tados. Essa incidência pode ter vinculação com abatimento do Bloco Cotia, por reativação dos falhamentos; mais adiante, ao abordarmos cs falhamentos, veremos a implicação dessa pos sível reativação na área de São Paulo.

E verdade que até o presente nenhuma evidência dire ta de reatjuação de falhas antigas foi apresentada e um mode lo puramente tectônico encontra dificuldades para explicar os casos como o de Alumínio. Um modelo desse tipo não elimina a possibilidade de controles puramente jitológicos, mas as investigações ainda devem prosseguir antes de se estabelecer uma generaljzâção. 


\section{CAPITULO 5 - ANÁLISE DO MAGMATISMO}

o magmatismo na área focalizada gerou:

1 - corpos restritos de rochas básicas, transformadas em anfibolitos e metabasitos;

2 - corpos de rochas granitóides;

3 - pequeno dique de diabásio a Ssw de Brigadeiro To bias e restritas ocorrências de rochas alcalinas no vale do rio Sarapuí.

ção das encaixantes, como os metabrasitos a SE de Pilar Sul, ora são francamente discardantes, como os metabasitos de Alumínio e de Juquitiba. Tais corpos indicam magmatismo pré-metamörfico, a que chamaremos fase de magmatismo $I_{1}$, atin gindo sequências de sedimentos rítmicos. Esse magmatismo, onde se pode observar vestigios de antigas texturas e minera logias, foi de caráter básico.

Os corpos granitóides mostrados na Figura 4, reunem características que permitem grupá-los em duas categorias.

Os maciços análogos ao Complexo de Piedade, bem como os de Sorocaba e São Francisco. têm as seguintes feições mais importantes:

1 - são corpos alongados, com eixo maior paralelo à orientação dos dobramentos das encaixantes;

2 - os contatos são em grande parte concordantes, mas discordâncias são claras nas extremidades;

3 - as encaixantes sofreram ação térmica de contato, inclusive com adição de elementos químicos;

4 - a rocha tem sempre uma fração fina, de natureza granodiorítica a granítica, com foliação conspícua, que, ape sar das ondulações provocadas pelos fenocristais, mostra dí 
reção geral concordante com a dos dobramentos das encaixan tes. Fácies dioríticas são vistas ocasionalmente, como nos maciços de Sorocaba e São Francisco;

5 - feldspatos se desenvolveram tardiamente nessas rochas, ora se orientando em consonância com a foliação, ora dispondo-se caoticamente. Aparentemente, a feldspatização começou sob o império de um campo de forças e prosseguiu mes mo depois da sua dissipação. Esse processo não se deu uni formemente, mas incidiu com diferentes intensidades em difé rentes zonas;

6 - indícios de cataclase são generalizados nas ro chas;

7 - quando as encaixantes são rochas epimetamórficas, entre estas e as granjtóides aparecem faixas de rochas atri buíveis às fácies de transição xisto verdelanfibolito e anfi bolito (Turner, 1968), o que indica a colocação dos corpos em núcleos de estruturas culminantes;

8 - são corpos circunscritos.

A classificação tectônica de maciços com tais carac terísticas é problemática. Hasui et al. (19eg) consideraram- nos tardi-tectónicos, enquanto $R$. Ellert (in Coutinho, 1972) qualificou-os sintectônicos. De fato, eles têm característí cas de intrusivos, ascendendo a nível mesozonal, contemporâ neamente a uma fase tectogênica, e nessas circunstâncias po de-se atribuir-lhes qualificação de tardi-tectônicos. Por outro lado, suas características petrográficas são típicas de maciços sintectônicos, como descritas, v.g., por Marmo (1971).

Read (1957) considerou que os corpos graniticos po dem ser autóctones ou não e, neste caso, o deslocamento da massa magmática através da coluna de rochas poderia ser de extensões variáveis. De acordo com o grau de ascensão, sepa rou ele os macjços parautóctones, os maciços intrusivos e os 
plütons graníticos. Os maciços autóctones correspondem aos corpos sintectônicos, os maciços intrusivos aos tardi-tectônicos e os plútons graníticos aos pós-tectónicos. Os mací ços parautóctones correspondem a uma transição entre corpos sintectônicos típicos e tardi-tectônicos, sendo difícil atri buir-lhes uma qualificação magmatectônica simples.

Face a essa dificuldade de classificação, julgamos preferível retornar à definição original de F. Eskola, que considera sintectónicos os corpos formados contemporâneamente à tectogênese. Então, o termo sintectônico, lato sensu, inclui os corpos tardi-tectônicos.

Podemos então considerar os maciços em pauta sob a qualificação de sintectônicos parautóctones, constituídos numa fase de magmatismo I. ${ }_{2}$.

Quanto aos corpos de Pilar do Sul, da Serra do Lo pes e do Turvo, as suas características principais são:

1 - só o corpo do Turvo guarda uma relação de dire ção de alongamento com orientação de estruturas das encaixan tes. Nos outros dois, a discordância é flagrante;

2 - as encaixantes metamórficas mostram efeitos de metamorfismo de contato, inclusive com adição de elementos químicos;

3 - a rocha é homogênea, de natureza granítica, sem ostentar qualquer foliação;

4 - fácies de granulação fina ocorre nas bordas, re fletindo aparentemente condições de esfriamento mais rápido; Uma foliação aí aparece, talvez vinculável a fluxo do magma;

5 - indícios de cataclase existem, mas atribuíveis ao processo magmático (protocataclase);

6 - são corpos circunscritos (Raguin, 1965).

Tais características permitem classificar esses três 
corpos como pós-tectônicos, formados numa fase de magmatismo $I_{3}$.

Quanto ao magmatismo básico e alcalino (Fase $I_{4}$ ) que ocorreu em tempos mesozóicos, ele se vinculou a um amplo processo de reativação da plataforma Sul-Americana, a que Almeida (1967) chamou de Reativaçäo Wealdeniana. 


\title{
CAPITULO 6 - ANALISE DO METAMORFISMO
}

\author{
BLOCO SAO ROQUE
}

No Bloco São Roque, devemos considerar o metamorfís mo regional ou dínamo-termal e o metamorfismo termal ou de contato.

o metamorfismo regional na maior parte da área de me tamorfitos foi de baixo grau, dentro da fácies xisto verde (Turner, 1968). Assim é que nas rochas metapeliticas e me tapsamíticas, as associações minerais são combinações diver sas de sericita-moscovita, clorita, biotita, minerais do gru po do epídoto, quartzo, albita, grafita e ocasionalmente mi croclíneo. Nas rochas calcárias as paragêneses envolvem car bonatos, actinolita-tremolite, quartzo, grafita e sericita. Os metabasitos são constituídos de minerais como: actinolita-tremolita, clorita, minerais do grupo do epidoto, quartzo, calcita, titanita, biotita.

Em termos de distribuição espacial, filitos cedem lu gar a xistos ao nos aproximarmos dos corpos graniticos. Nes ses xistos, com maior frequéncia as associações são compatí veis com a fácies xisto verde, mas por vezes constatamos a presença de granadas, oligoclásio, indicando condições mais drásticas. Um corpo de anfibolito tipico existe intercalado nesses xistos, junto ao Maciço de São Francisco, constituído essencialmente de hornblenda e andesina, o que atesta condi ções de fácies anfibolito (Turner, 1968).

Não foi possível nesta instância delimitar as áreas correspondentes às fácies nos mapas geológicos anexos. Tam bém não ficou patenteada a existência de rochas atribuíveis à fácies de transição entre xisto verde e anfibolito (Turner, 1968). o que naturalmente exige investigação em maior detalhe. 
A existência dessas faixas de maior grau metamórfico nas bordas dos corpos granitóides não constitui novidade. Na Folha de Jundiai, a norte da de São Roque,Hasui et al. (1969), Penalva e Hasui (1970) e Coutinho (1972) constataram sua pre sença ao redor dos maciços do Itaqui, Tico-Tico e Cantareira. A largura delas varia de algumas centenas de metros a cerca de $2 \mathrm{~km}$.

Ainda nas vizinhanças dos corpos granitóides, as ro chas encaixantes foram afetadas por metamorfismo termal, de senvolvendo-se hornfels e maculando os xistos.

Os xistos maculados têm microporfiroblastos e porfi roblastos de moscovita, sem orientação preferencial. Eles tendem a destruir a xistosidade da rocha e, eventualmente, no contato com o corpo intrusivo, aparecem biotita e/ou moscovi ta-hornfels.

o metabasito de Alumínio, junto ao maciço de São Francisco, acha-se afetado, exibindo minerais compatíveis com a fácies hornblenda-hornfels; à distância, aparecem associa ções da fácies albita-epídoto-hornfels (Turner, 1968; Turner $e$ Verhoogen, 1960). Tais rochas podem ser qualificadas como hornfels básicos.

Os hornfels mais importantes, todavia, são os calco- silicatados, com um séquito de minerais condizentes com a fácies albita-epídoto-hornfels e, mais próximo à intrusão, tam bém com a fácies hornblenda-hornfels, esta marcada pelo apa recimento de diopsídio.

Essas fácies de contato também não foram demarcadas nos mapas anexos.

Ainda nas adjacências do contato, há que se lembrar as introduções de elementos por soluções pneumatolíticas e hi drotermais. Turmalinização é um processo praticamente uni versal. Os metapelitos têm normalmente alguma turmalina co mo acessório, em minúsculos grãos subarredondados (detrítí 
cos) ou euédricos neoformados à custa de boro do antigo sedi mento (Wizliams et al., 1954). A turmalina a que nos referi mos, entretarto, formou cristais mais desenvolvidos, em boa parte poiquiloblásticos, dispostos sem orientação preferen cial ou ao longo da xistosidade ou preenchendo planos de cí salhamento. Apatitização também incidiu nos mesmos moldes, mas mais discretamente. Pirita disseminada, em porfiroblas tos euédricos e subédricos, segundo Turner e Verhoogen(1960), resultariam da reação de $\mathrm{H}_{2} \mathrm{~S}$ com silicatos ferrosos(biotita, clorita).

A par de tais processos, observa-se ainda a fixação de álcalis derivados do magma granítico, pelo excesso de alu mina dos metapelitos, resultando na formação de feldspatos (Turner e Verhoogen, 1960). Isso se verificou no canto nor deste da Folha de São Roque, chegando a se desenvolver gnais
ses.

Por fim, merece destaque o fato de se notar nas para gêneses que refletem condições mais drásticas de formação, a presença de associações como biotita-clorita e zoisita-clino zoisita, que traduzem desequilíbrio (WiZliams et al., 1954; Turner e Verhoogen, 1960) e que poderiam ser atribuidas a atenuação das condições físicas reinantes na rocha.

Assim, no Bloco São Roque dois eventos metamórficos parecem ter tido lugar, seguramente: anfibolito;

1 - metamorfismo regional, em fácies xisto verde a

2 - metamorfismo de contato, em fácies albita-epídoto-hornfels e hornblenda-hornfels.

\section{BLOCO ITUPARANGA}

Neste Bloco, só litologias metapelíticas e metapsamí ticas têm representação, sendo extensivas a elas as observa ções feitas no item anterior. Assim é que, ao redor dos cor pos granitóides, aparecem micaxistos, eventualmente até 
gnaisses metassomáticos. Em posições proximais, esses xis tos ostentam hornblenda, oligoclásio e granada, que indicam condições de metamorfismo em fácies anfibolito.

Se à distância as litologias são de fácies xisto ver de e em posições proximais às intrusões são de fácies anfibo lito, seria de se esperar termos atribuiveis à fácies de tran sição entre xisto verde e anfibolito (Turner, 1968), mas nes te nível de estudo não pudemos defini-los, talvez por serem muito reduzidos.

As considerações feitas no tocante à ação de contato no Bloco São Roque são também aqui observadas.

\section{BLOCO COTIA}

Os metamorfitos da Folha Pilar do Sul, a sul do Ihamento de Taxaquara, são metapelitos, metapsamitos e meta basitos, nos quais se observam as mesmas feições descritas para o Bloco São Roque, no tocante ao metamorfismo regional e também às ações de contato.

Nos migmatitos do Bloco Cotia, o paleossoma tem asso ciações minerais compatíveis com a fácies anfibolito (Turner, 1968). Saussuritização de plagioclásio, aparecimento de clo rita associada com biotita parecem ser relacionáveis com con dições físicas menos intensas.

Em resumo, no Bloco Cotia evidencia-se uma fase de metamorfismo regional na fácies xisto verde até anfibolito. Seguiu-se metamorfismo de contato, em duas épocas, a primei ra em conexão com o Complexo Piedade e a segunda, com as in trusões pós-tectônicas.

Quanto à migmatização, ela pode ser associada à prí meira ou segunda fase de metamorfismo, dependendo do modelo genético. Não nos cabe discutir a origem dos migmatitos. Na vasta bibliografia pertinente, três modelos se defrontam: o 
magmático, propondo derivação magmática do neossoma, o anate xítico, considerando fusão parcial e segregação do neossoma, e o modelo metassomático, pelo qual haveria difusão de ele mentos químicos através das rochas, em estado sólido. Cada modelo, nos seus mecanismos, admite variantes numerosas.

Talvez a associação desses migmatitos com o Complexo Piedade possa indicar relação do neossoma com a intrusão, co mo sugerem Turner e Verhoogen (1960). Nesse caso, a migmati zação se vincularia à segunda fase de metamorfismo.

\section{BLOCO JUQUITIBA}

No Bloco Juquitiba, os migmatitos com estrutura es tromatítica têm paleossoma constituído por combinações de mí
nerais, dos quais os mais significativos são:

1 - em metapelitos: quartzo, moscovita, biotita, gra nada, hornblenda e oligoclásio; moscovita;

2 - em metapsamitos: quartzo, oligoclásio, biotita,

3 - em rochas calco-silicatadas: quartzo, carbonato, hornblenda, diopsídio, biotita, moscovita, granada, microclí neo: biotita.

4 - em metabasitos: hornblenda, andesina, quartzo,

Nos migmatitos oftalmiticos os mesmos minerais dos itens l. e 3 são observados.

Tais paragêneses são condizentes com a fäcies anfibo lito (Turner, 1968).

Nas proximidades de intrusões granitóides observamos - desenvolvimento de turmalina, apatita e pirita, atribuível a ação de contato. A par disso, nos metapelitos desenvolvem- se porfiroblastos de moscovita sem ostentar orientação pre 
ferencial aparente e dispondo-se mormente em discordância com a folíação.

O desenvolvimento de porfiroblastos de moscovita é notado também à distância de corpos graníticos, fato que Cou tinho (1972) já observara na região de São Paulo. Difícil é, sem análise de detalhe, verificar a existência de orientação preferencial por causa de rotações que sofreram, comprovadas por flexões, e transposições significativas, como veremos adiante. Frequentemente, vemos dobras da xistosidade (para lela à estratificação) e os porfiroblastos alongados segundo posição plano axial nos núcleos; nos flancos, de dobras fé chadas, o alongamento é oblíquo, convergindo para os nūcleos e, em flancos de dobras cerradas e j.soclinais, as micas têm disposição concordante com a xistosidade. Esse arranjo é su gestivo de uma orientação prévia dos porfiroblastos e rota ções relacionadas com o dobramento.

Por fim, cumpre destacar a presença generalizada de clorita em associação com biotita e a existência de plagio clásios saussuritizados e zonados combordas albíticas, que são indícios de transformações em condições físicas atenua das (Williams et al., 1954).

Em resumo, no Bloco Juquitiba reconhecemos uma fase de metamorfismo regional na fácies anfibolito, com migmatiza ção, seguindo-se ação de contato. A formação de porfiroblas tos de moscovita se deu em bordas de intrusões, como também regionalmente.

No prolongamento do Bloco Juquitiba para NE, Coutinho (1972) reconheceu evidências de transformações diaftoréticas. o metamorfismo retrógrado certamente se processou a posteriori.

SERIE FACIAL

No Grampian Highland da Escócia, as fácies presentes foram consideradas como normais até que Miyashiro (1961) troduziu o conceito de série de fácies, reconhecendo a impor 
tância da pressão no processo metamórfico, além da temperatü ra. De lá para cá várias séries foram descritas, envolvendo desde altas pressões e baixo gradiente térmico até baixas pressões e alto gradiente térmico.

$\mathrm{Na}$ área focalizada, a persistência da moscovita ates ta que não se chegou a condições mais elevadas da fácies an fibolito e as associações minerais mais significativas não chegaram a se desenvolver, de modo a se poder estabelecer correlação com as séries de fácies já reconhecidas. Os da dos apresentados possibilitam reconhecer zonas da clorita,da biotita e da almandina, mas as demais talvez apareçam mais a sudeste, rumo ao litoral.

Coutinho (1971), analisando a região de São Paulo, concluiu haver semelhança com a sërie facial de New Hampshire (Winkler, 1967), de altas pressões e temperaturas,ligeiramen te inferiores àquelas que atuaram no conjunto Barroviano. Ad mite, porém, que para sudoeste seria possivel definir uma sé rie Barroviana. De fato, o mineral crítico diferenciativo entre as duas séries é a cianita, que não existiria na re gião de São Paulo, mas Melcher et al. (1973) descrevem no Vale do Ribeira.

\section{METAMORFISMO CATACLĀSTICO OU DINÂMICO}

Hennies et al. (1967) descreveram os efeitos da cata clase ao longo dos falhamentos de Taxaquara e Pirapora. Os mesmos incidiram também nos falhamentos de são Roque e de Caucaia.

A cataclase se manifestou de modo relevante em chas granitóides. O processo de moagem não se deu de modo uniforme, havendo faixas onde foi mais intensa, alternando- se com outras em que a intensidade foi menor. Tais faixas são de espessuras centimétricas a decamétricas e somam largu ras de várias centenas de metros e até superiores a $1 \mathrm{~km}$. 
No início da cataclase, a rocha granitóide passa a exibir fraturas segmentando-a e ao microscópio distinguem-se grãos fraturados com bordas granuladas. Os planos de cisa lhamento, com a evolução do processo, aumentam em densidade, isolando fragmentos de rocha cada vez menores. Enquanto per sistem fragmentos isolados por farinha resultante da moagem, com predomínio daqueles, podemos cognominar a rocha de bre cha tectônica (Fotomicrografia 8).

Em estágio mais avançado, acaba-se tendo grãos de mi nerais, os porfiroclastos, de formas variadas, isolados na massa fina. São os flaser-gnaisses de origem cataclástica.

Posteriormente, os porfiroclastos, de dimensões mais reduzidas, ganham formas lenticulares e a rocha é então deno minada augen-gnaisse cataclástico (Fotomicrografia g).

A subsequente redução dos porfiroclastos a níveis submilimétricos leva aos milonitos, já com franco predomínio da matriz fina (Fotomicrografias 10, 11,13 e 14). Numa eta pa final de moagem, nenhum porfiroclasto é visto, as rochas são foliadas e lembram filitos. A elas tem-se denominado fi lonitos (Fotomicrografias 12, 15 e 16).

0 atrito intenso pode possibilitar recristalização de minerais e quartzo neoformado se constitui. A rocha é um ul tramilonito (Fotomicrografias 17 e 18 ).

Com a moagem, os produtos da fragmentação tendem a se infileirar, resultando uma lineação macroscopicamente vi sivel, que reflete a movimentação dos blocos (Foto 7 ).

No tocante ao comportamento dos minerajs face ao pro cesso de moagem, é de se notar que dentre os minerais comuns nas rochas granitóides, as micas são as mais sensiveis, (Foto micrografia 19), seguindo-se o quartzo e, por fim, os felds patos (Fotomicrografias 20 e 21 ). São estes que nos milo nitos ainda persistem sob forma de fenoclastos. 0 processo começa com distorções reticulares, que se manifestam em ex 


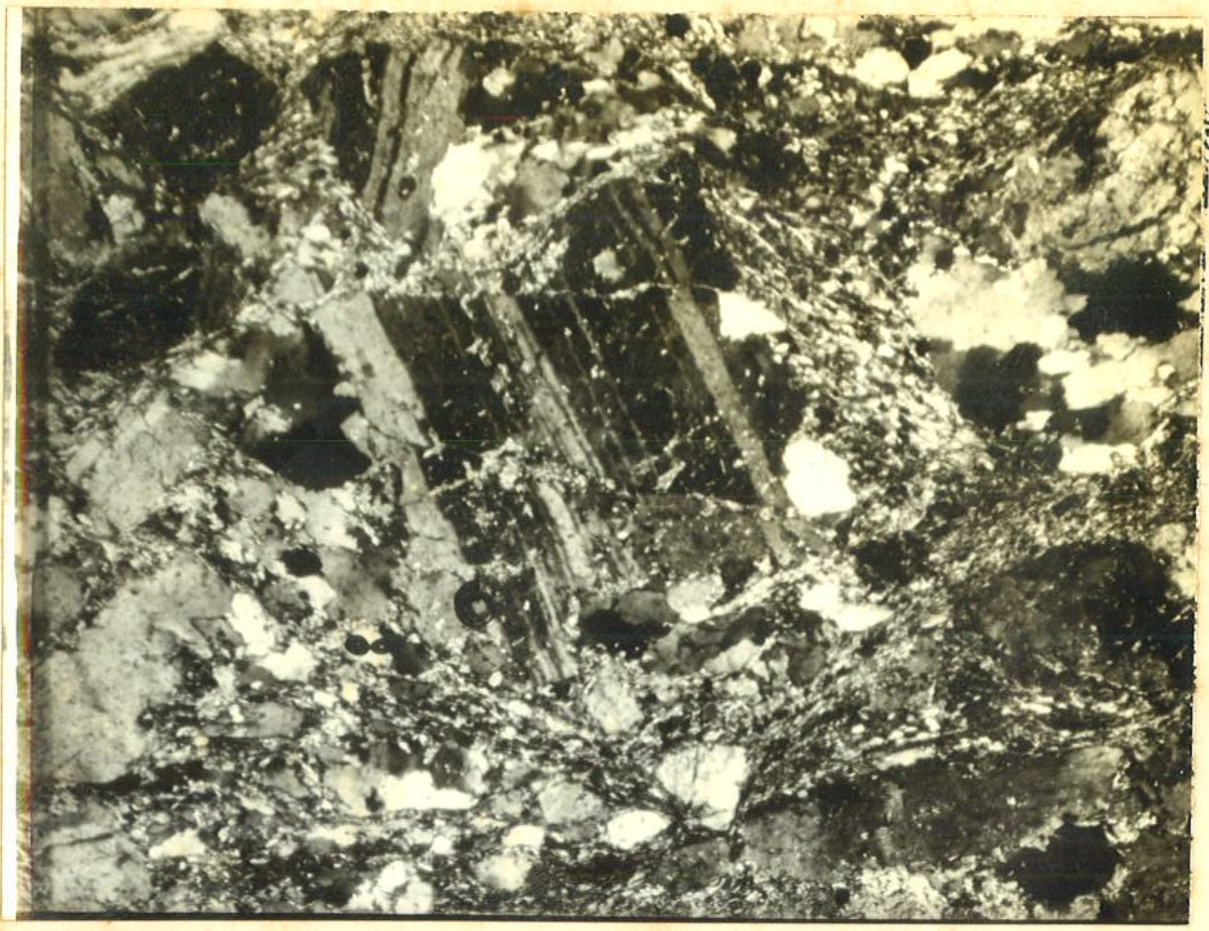

FOTOMICROGRAFIA 8 - Brecha tectônica derivada de tipo Pirituba. Notam-se faixas já granuladas sios fraturados e fletidos. A biotita está granulada.

"Granito" 192X N+. Amostra 117-A, $4 \mathrm{~km}$ a $\mathrm{N}$ de Piedade. plagioclá totalmente

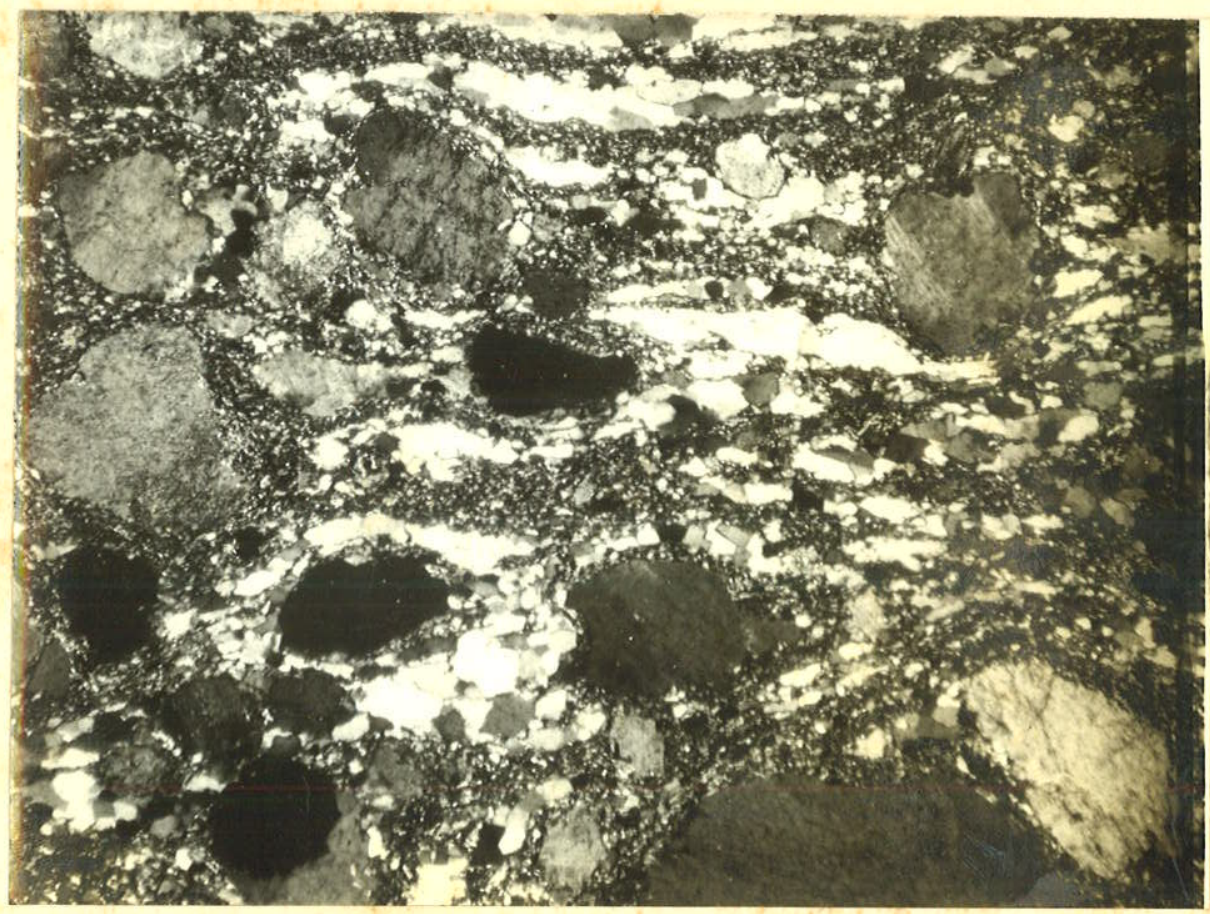

FOTOMICROGRAFIA 9 - Augen-gnaisse derivado de "Granito" tipo Pirituba. Neste estágio o quartzo se acha em franco processo de moagem. Os feldspatos têm bordas em moldura.Uma foliação já se desenvolveu na rocha. $192 \times \mathrm{N}+$. Amostra $117 \mathrm{~B}, 4 \mathrm{~km}$ a $\mathrm{N}$ de Piedade. 


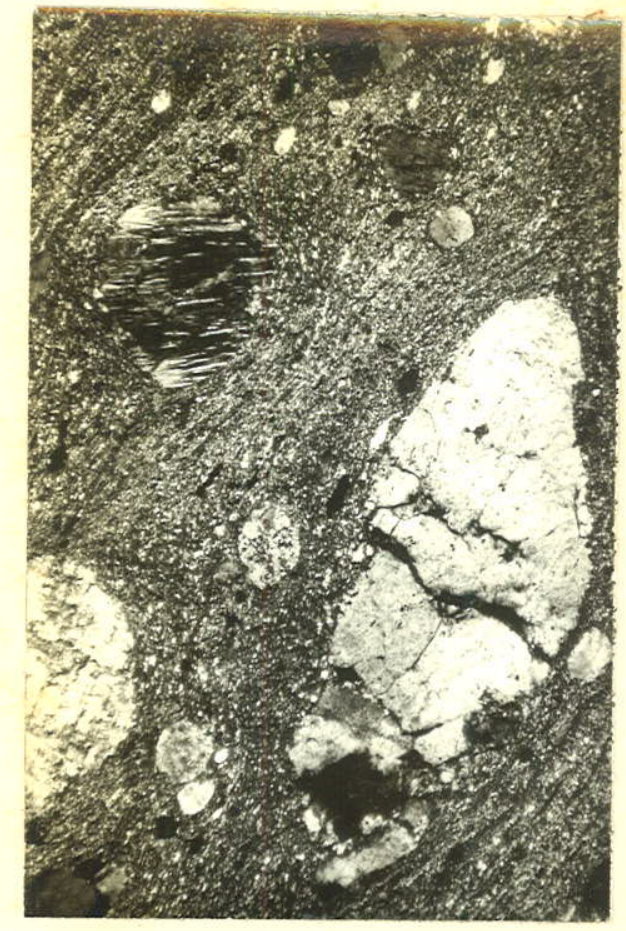

FOTOMICROGRAFIA 10 - MilONito derivado de "Granito" tipo Pirituba. Os fenoclastos são de feldspatos e têm dimensões variadas.

$192 \times \mathrm{N}+$. Amostra $129 \mathrm{~A}$. FaIhamento de Caucaia, Sul de Tapiraí.

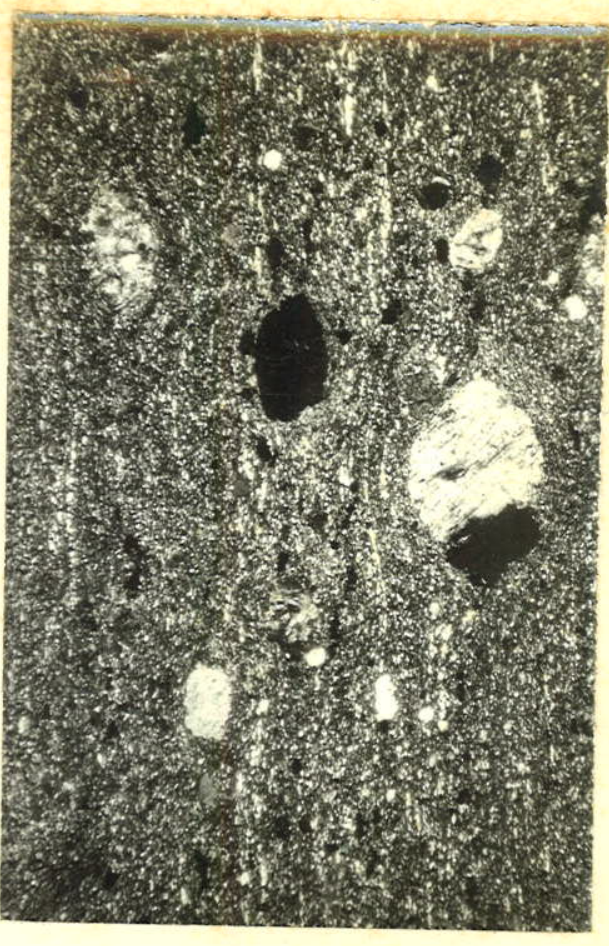

FOTOMICROGRAFIA 11 - MilOnito derivado de "Granito" tipo Pirituba. Os fenoclastos de feldspatos ga nham dimensões menores. Cordoes de quartzolbranco) são visíveis.

192X N+.Amostra 129B.Falhamento de Caucaia, a Sul de Tapiraí.

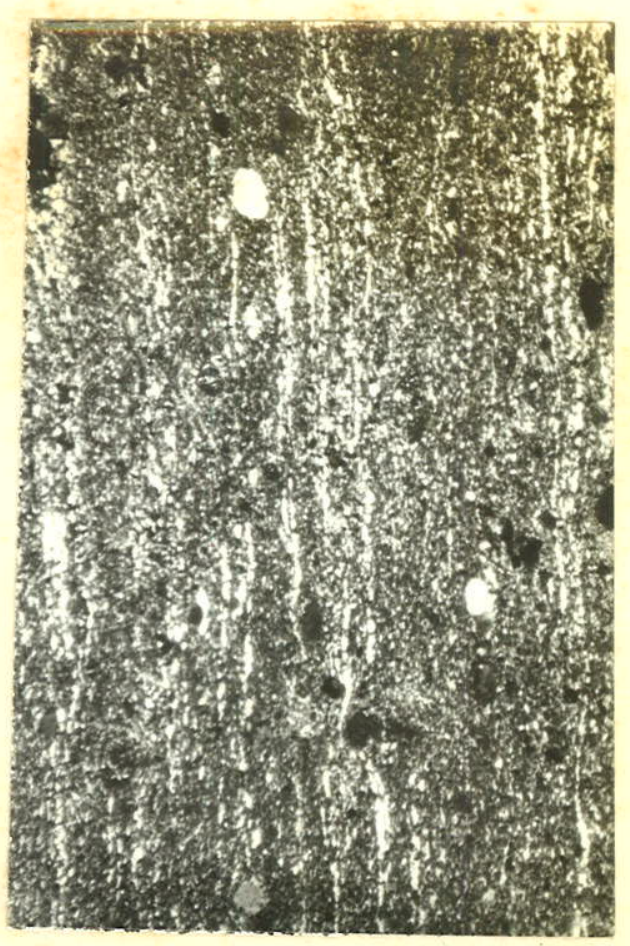

FOTOMICROGRAFIA 12 - FilOnito derivado de "Granito" tipo Pirituba. Os fenoclastos são imperceptíveis a vista desarmada. Neste estágio, os minerais acessorios ainda não começaram a se fragmentar. Os cordões de quartzo são nítidos. $192 \times \mathrm{N}+$. Amostra 129C.Falhamento de Caucaia, Sul de Tapiraí. 


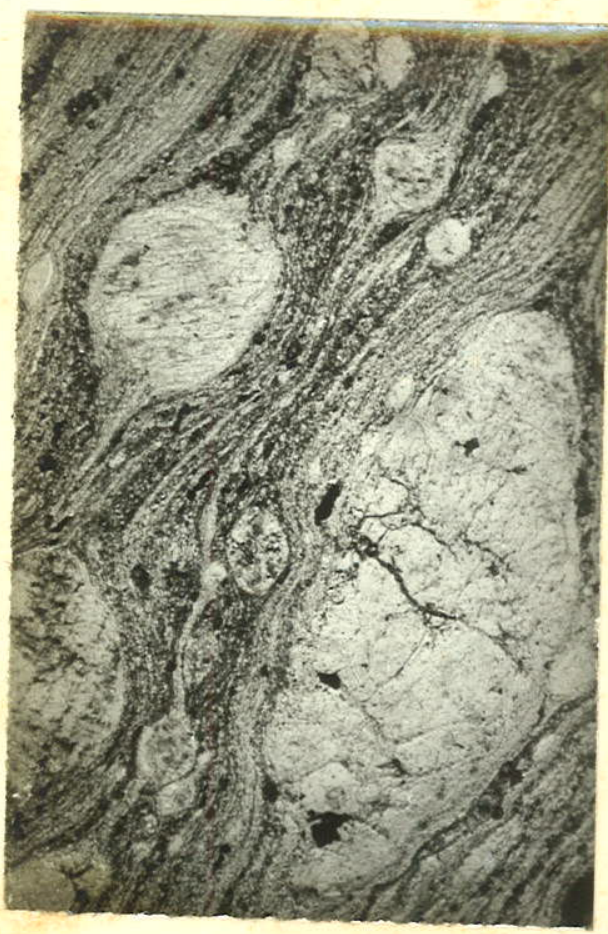

FOTOMICROGRAFIA 13 - A mesma imagem da fotomicrografia 10. mas a nícois paralelos. A foliação do milonito é nítida com formas onduladas.

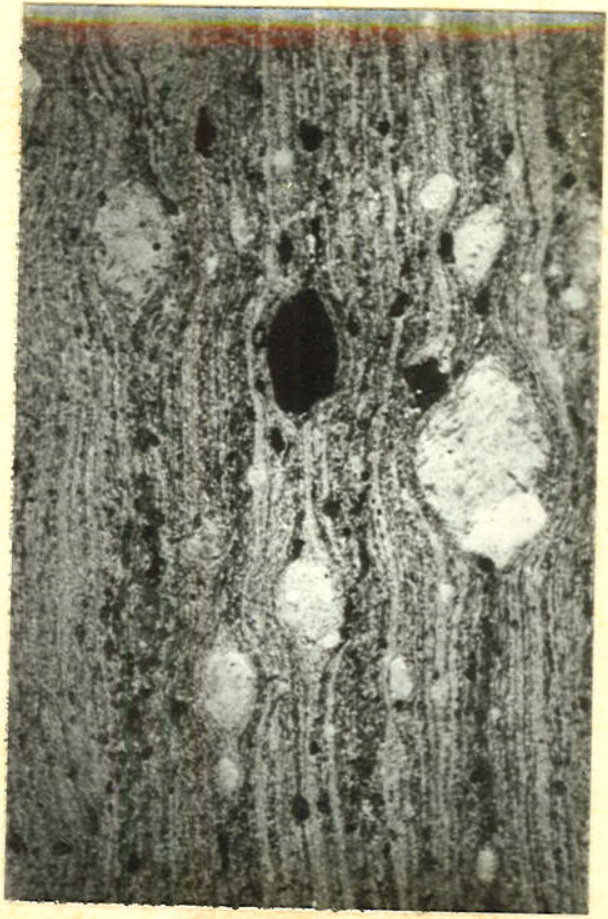

FOTOMICROGRAFIA 14 - A mesma imagem da fotomicrografia ll, mas a nícois paralelos. Com a diminui ção dos fenoclastos, a fō liaçäo se torna cada ve ż menos ondulada.

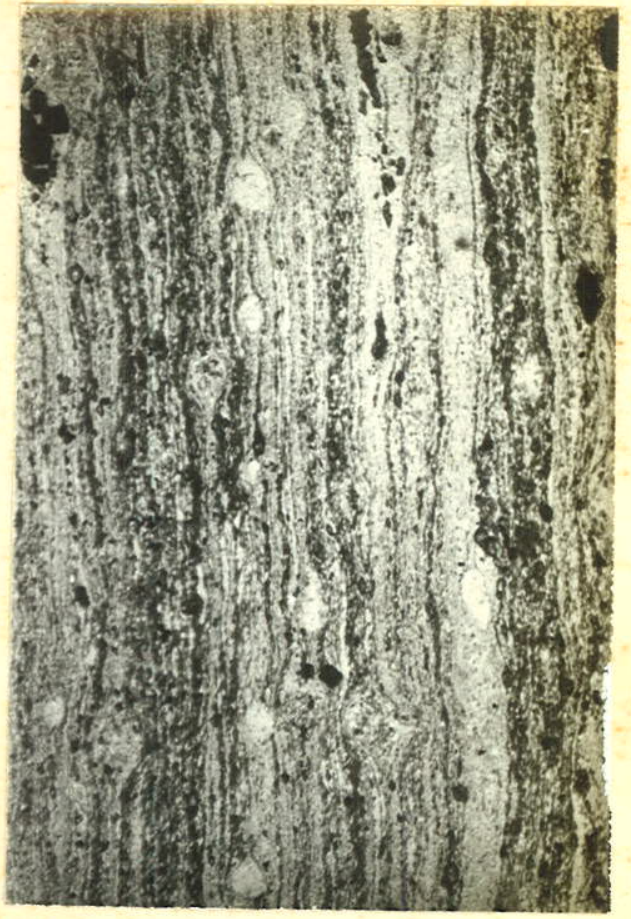

FOTOMICROGRAFIA 15 - A mesma imagem da fotomicrografia 12, mas a nícois paralelos. A foliação já é praticamente plana. 


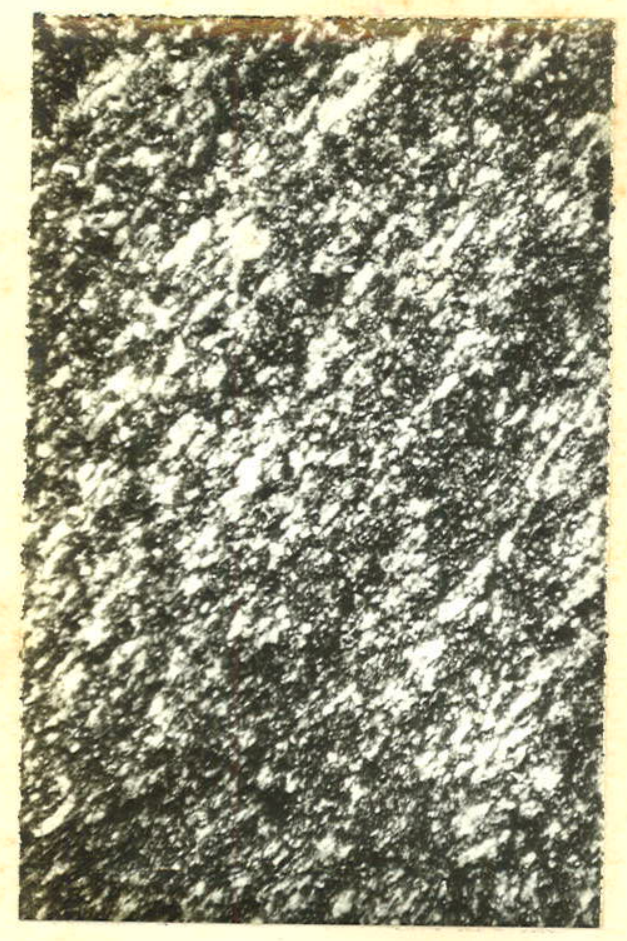

FOTOMICROGRAFIA 16 - Ultrami lonito, o estágio final da moagem. Todos os mine rais sofreram fragmentação. A foliação é conspí cua.

192X N*.Amostra $279,9 \mathrm{~km}$ NNE de Piedade.

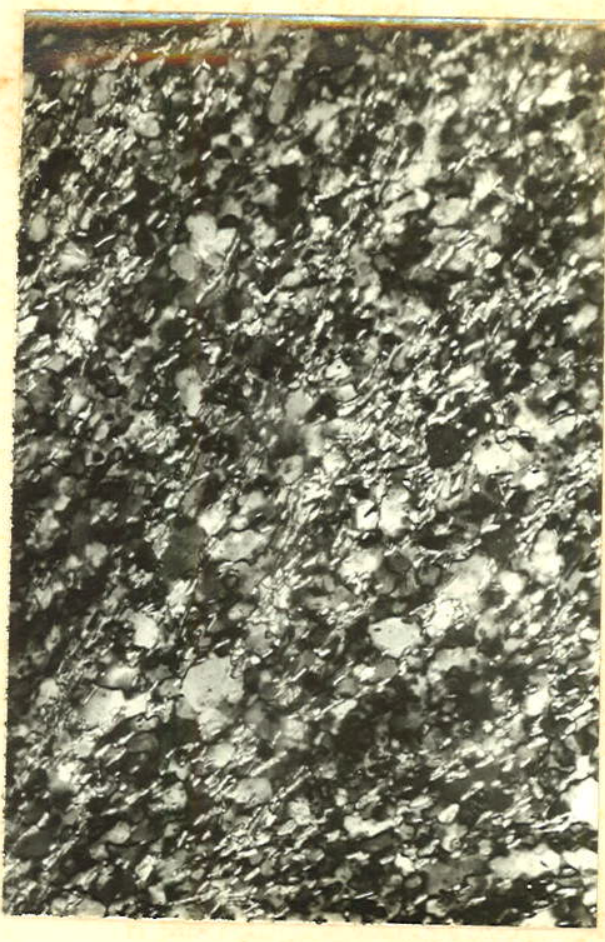

FOTOMICROGRAFIA 17 - Ultrami lonito, com recristalizá ção incipiente de quartzo. A foliação é conturbada pelos neocristais. $192 \times \mathrm{N}+$.Amostra 117C, 4 $\mathrm{km}$ a $\mathrm{N}$ de Piedade.

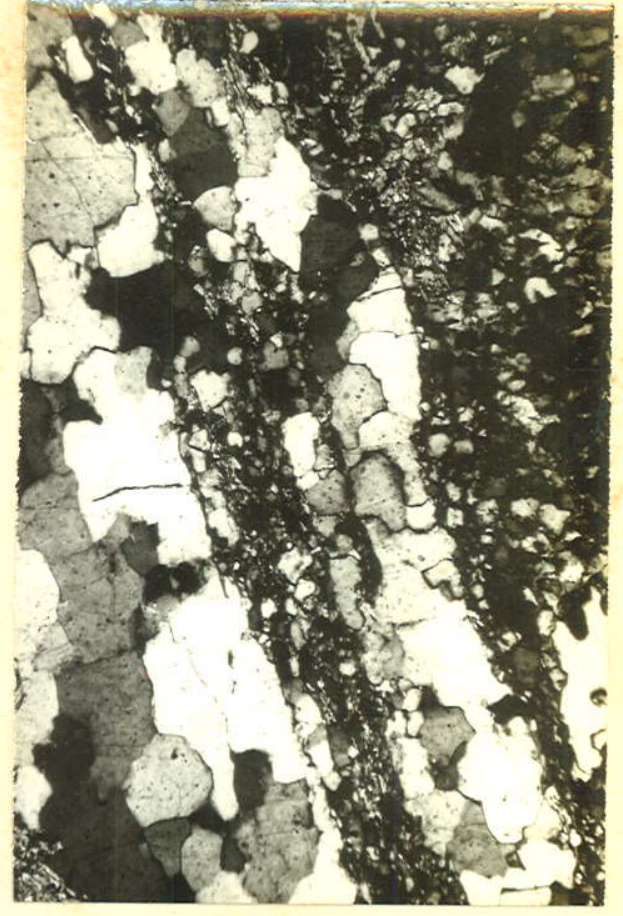

FOTOMICROGRAFIA 18 - UItrami lonito, com quartzo recristalizado, sem extinção ondulante.

$1200 \times \mathrm{N}+$. Mesma amostra da fotomicrografia anterior. 


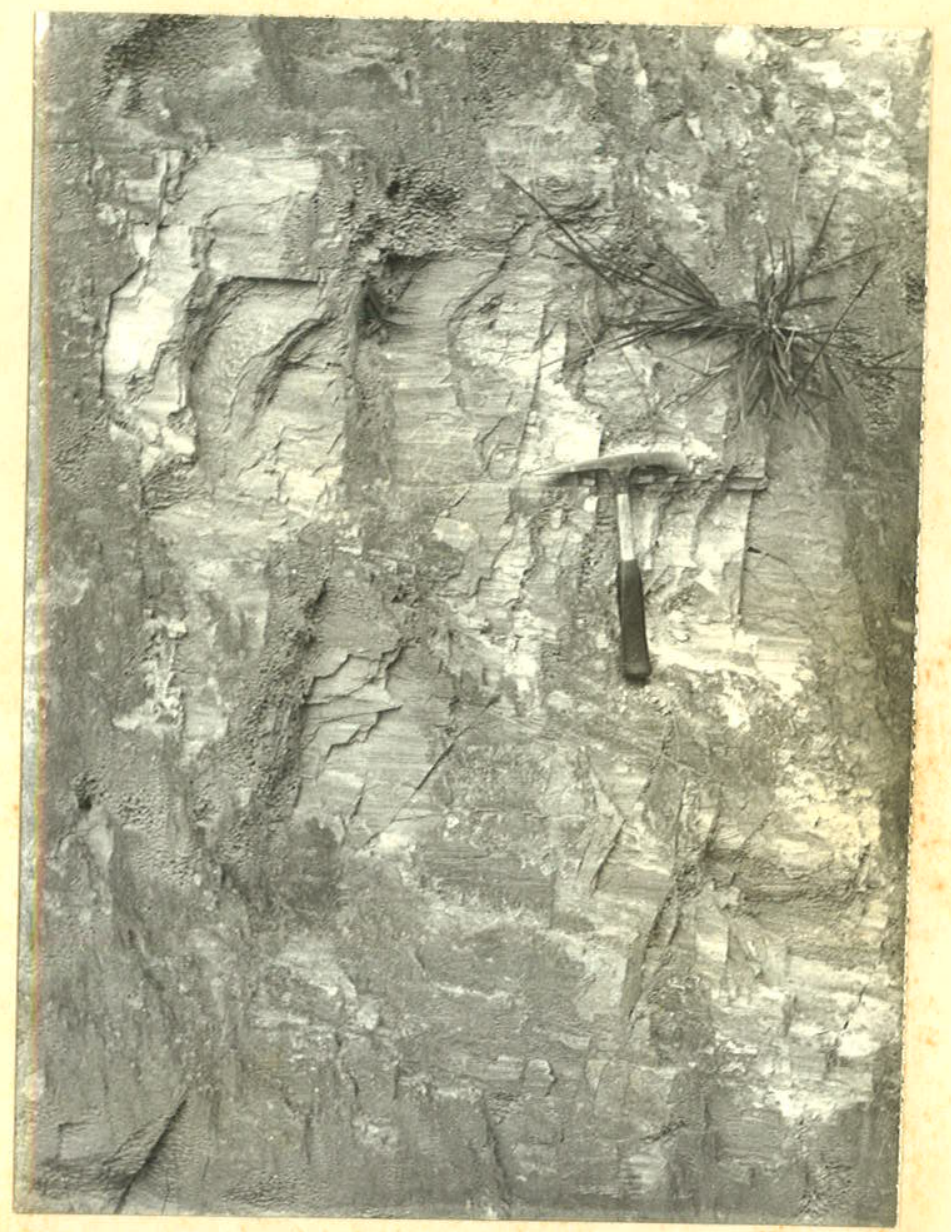

Foto 7 - Milonitos do Falhamento de Caucaia. Nota-se a disjunção segundo a foliação (no plano da foto), bem como sjstemas de juntas transversais e lineaçóes claras horizontais nos planos de foliação. Morro Grande, a nordeste de Caucaja do Alto. 


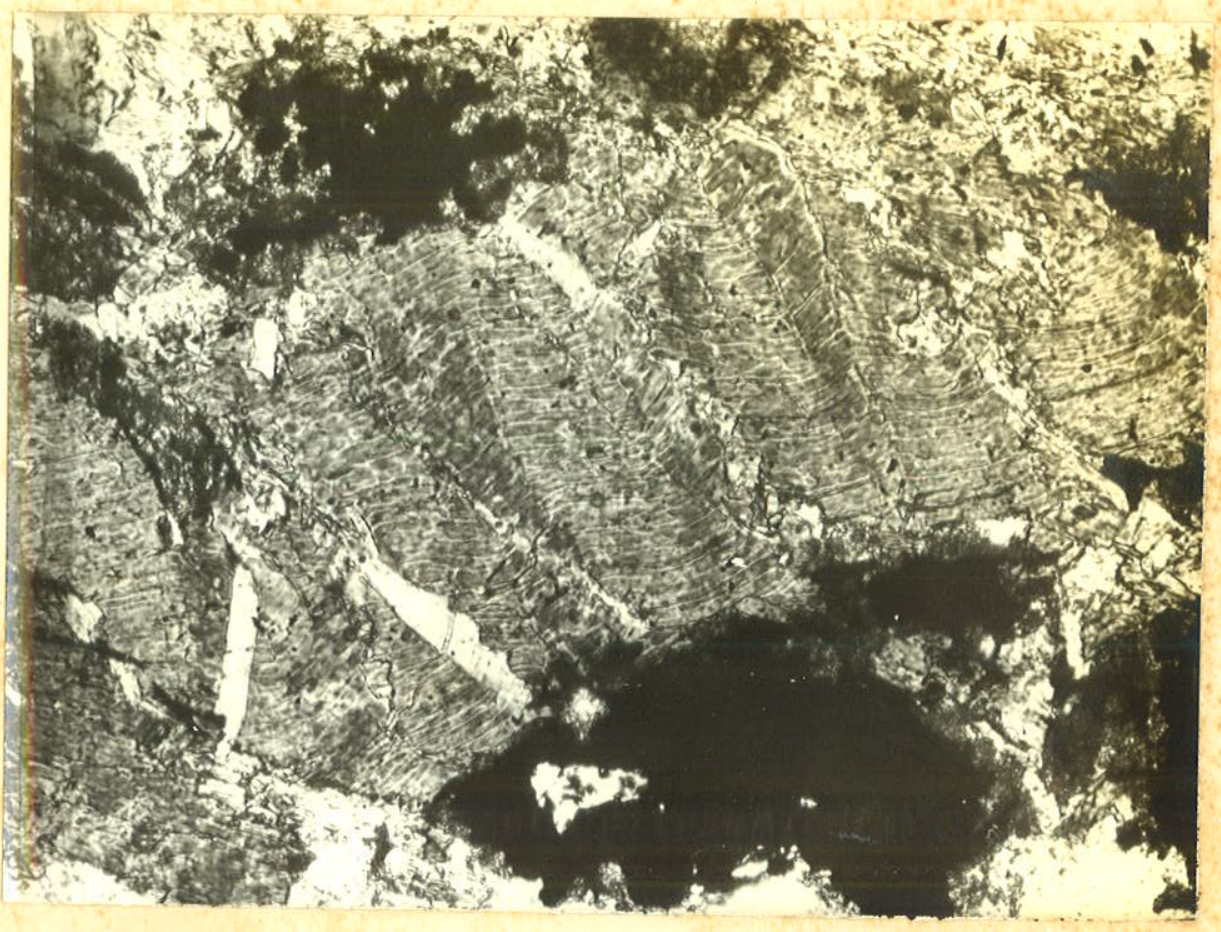

FOTOMICROGRAFIA 19 - Cristal de biotita em princípio de frag mentação. É o primeiro mineral a responder à cataclase. $192 \times \mathrm{N}+$. Amostra 367, $17 \mathrm{~km}$ a S de Ibiúna.

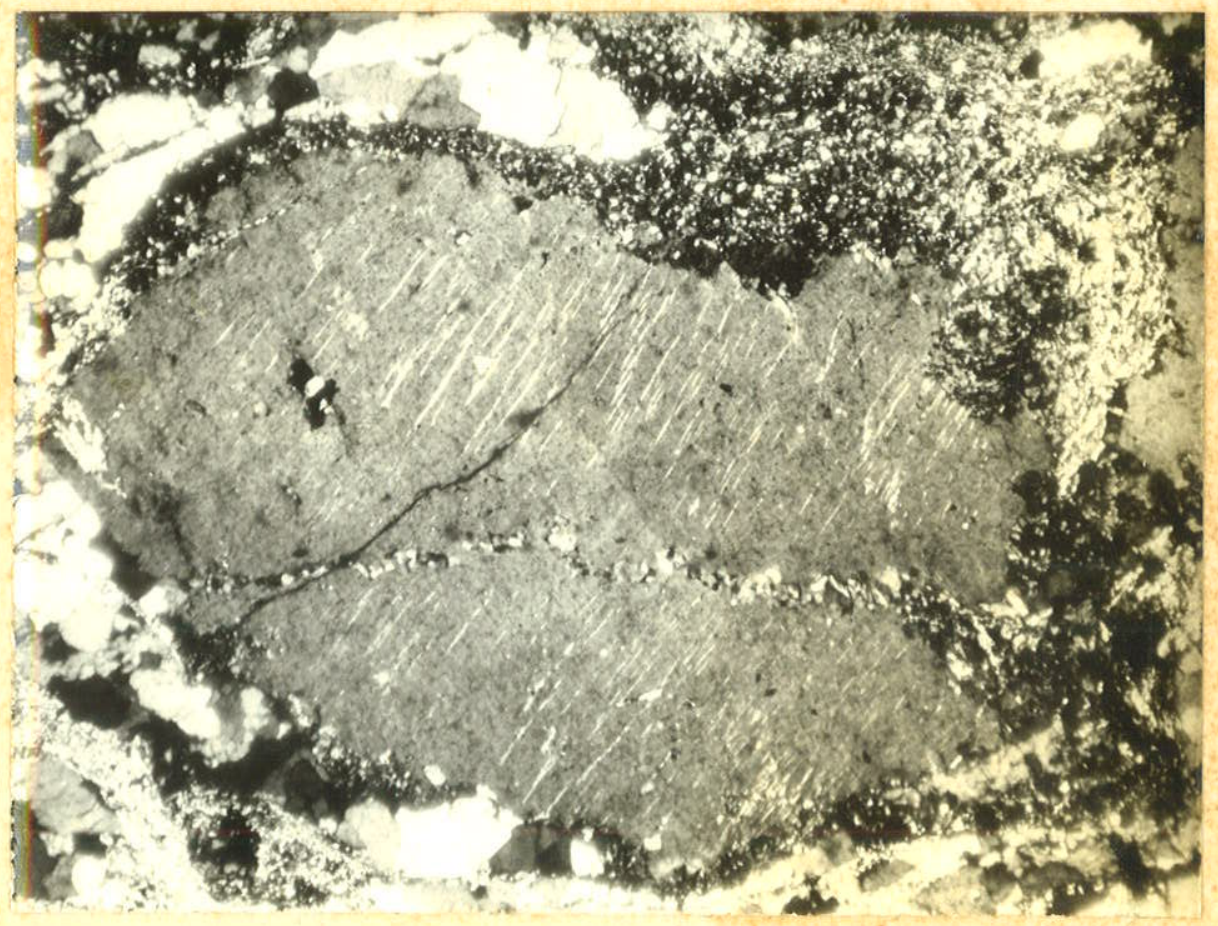

FOTOMICROGRAFIA 20 - Fenocristal de feldspato fragmentado, com bordas granuladas.

$192 \times \mathrm{N}+$. Amostra $367,17 \mathrm{~km}$ a S de Ibiüna. 
tinções ondulantes a nícois cruzados, flexão de planos de clivagem ou lamelas de geminação, fraturamento de grãos e de senvolvimento de texturas em moldura.

Epídoto, titanita, mineral opaco, apatita e turmali na permanecem incólumes até estágios avançados de cataclase (Fotomicrografias 22 e 23 ); acabam por se granular na passa gem de milonito para filonito. Talvez, com dimensões maio res, pudessem começar a se fragmentar em estágios menos avan çados.

Além de rochas granitóides, rochas metamórficas fo ram envolvidas no processo de falhamento. Dado o carāter in competente, os metapelitos não mostram indícios de moagem em faixas como descrevemos; apenas leitos de quartzo ou quartzi to se reduzem a massas de aspecto porcelânico. 


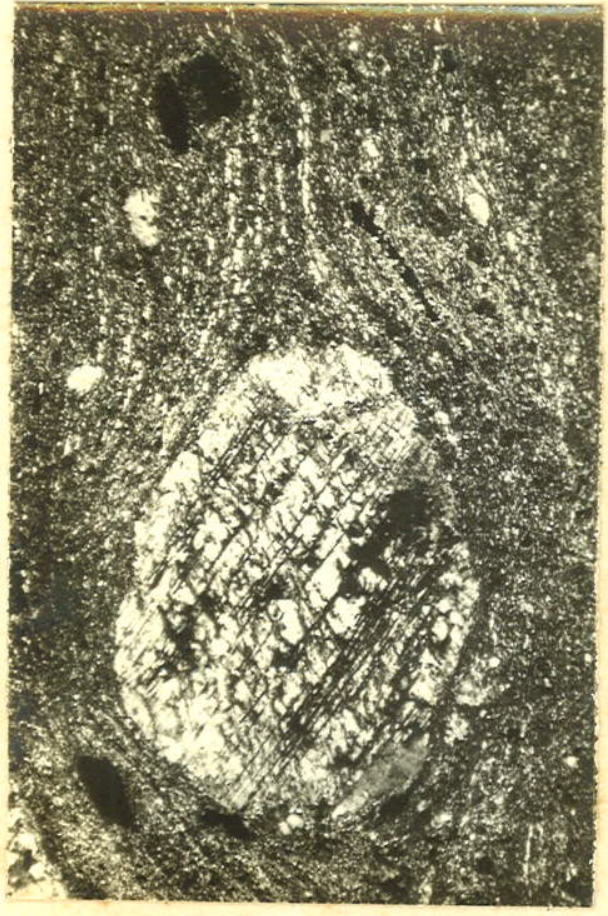

FOTOMICROGRAFIA 21 - POTficlasto de plagioclásio no milonito.

$192 \times \mathrm{N}^{+}$. Amostra 129, Fa Ihamento de Caucaia, Sul de Tapiraí.

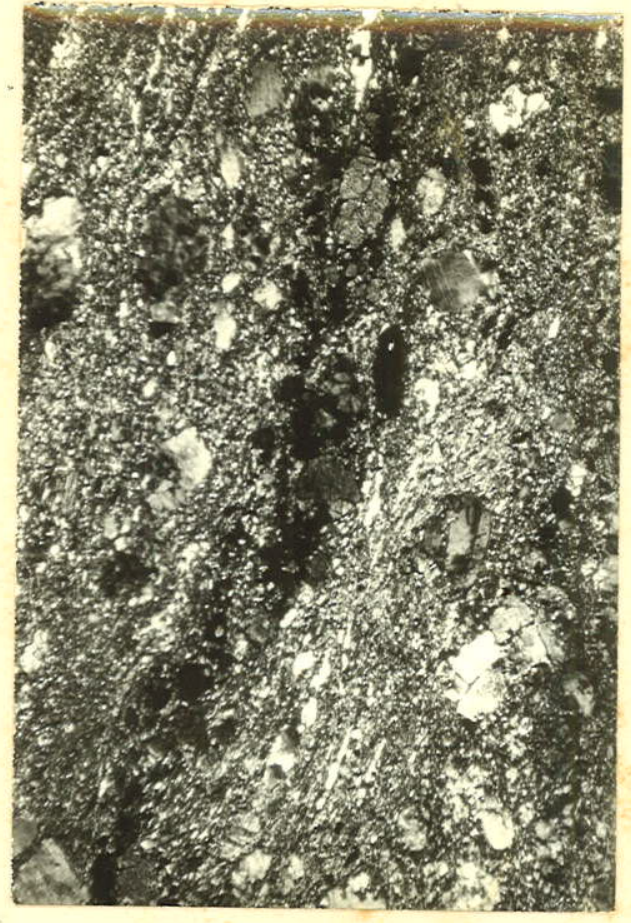

FOTOMICROGRAFIA 22 - Na faixa mais escura, turmalina, apatita,minerais opa cos, titanita e epídoto se mantêm ainda incólumes à cataclase.

192X N+.Amostra 130. FaIhamento de Caucaia, a Sul de Tapiraí.

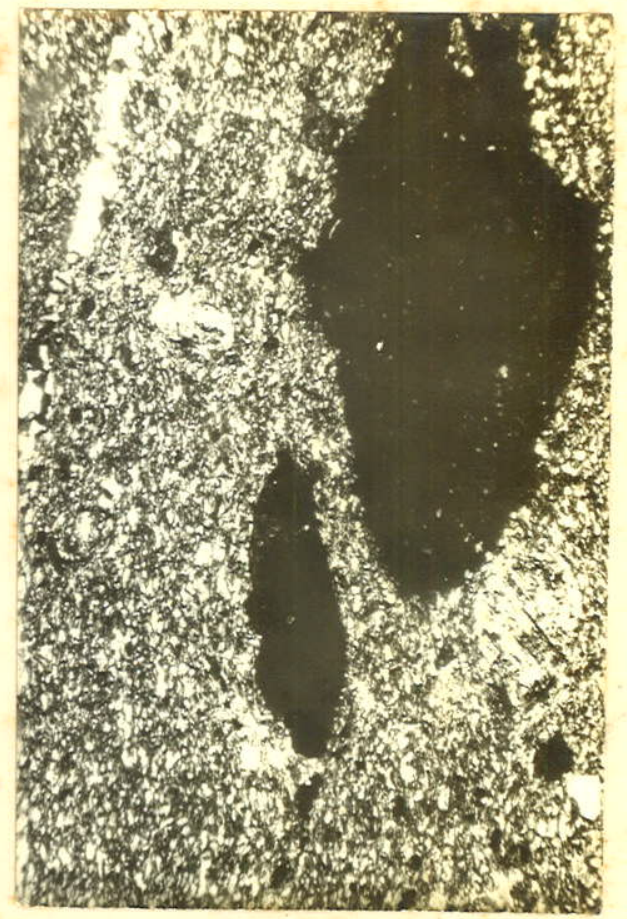

FOTOMICROGRAFIA 23 -Cristais de titanita ainda preser vados na matriz finamen= te moída.

$480 \times \mathrm{Nt}$. Amostra 129.FaIhamento de Caucaia, a Sul de Tapiraí. 


\title{
CAPITULO 7 - ANALISE DA ESTRATIGRAFIA
}

\author{
TRIPARTIÇÃO DO PRE-CAMBRIANO
}

Coube a Moraes Rego (1933) distinguir a Série São Ro que, incluindo os epimetamorfitos de idade algonquiana a oes te da Capital paulista, e o Complexo Cristalirc, arqueano, compreendendo as rochas gnáissicas do Estado de São Paulo.

Cita ele que F.F. de olivejra teria em 1889 se refe rido a uma Série da Serra de São francisco e que L.F. Gonza ga de Campos, na mesma ocasião, teria usado a designação sé rie de São Roque. Esses autores, porém, não se referiram a uma unidade estratigráfica, nem usaram a qualificação de sé rie; tão somente fizeram menção aos xistos que ocorrem nas regiões da Serra de São Francisco e de São Roque.

No Estado do Paraná, uma divisão análoga foi estabe lecida por Oliveira (1925), que posteriormente introduziu a designação Série Açungui (OZiveira, 1927). Oliveira e Leo nardos (1943) atribuem autoria desse nome a Derby em 1878 , mas este apenas se referiu aos xistos da regiẽo de Açungui, correlacionando-os à Série Minas.

A definição das duas séries levou a uma discussão so bre as relações entre elas. Moraes Rego (1933) edmitiu-as como contínuas através do vale do rio Ribeira de Iguape, com - que concordaram Carvalho e Pinto (1937). Apesar disso, oliveira e Leonardos (1943), à luz os dados então disponí veis, preferiram manter o nome São Roque no Estado de São Paulo e essa distinção geogräfica foi respeitada no Mapa Geo lógico do Estado de São Paulo (1963).

Mais recentemente voltou-se a considerar uma só uni dade com o nome Açungui, atribuindo-lhe prioridade em rela ção à denominação São Roque. 
Marini et al. (1967) e Hennies et al. (1967), dian te do que estabelece o Código de Nomenclatura Estratigráfica (American Commission of Stratigraphic Nomenclature, 1961), preferiram utiljzar a unidade litoestratigráfica Grupo, já que a Série é unidade cronoestratigráfica relacionada a uma época geológica.

0 , estudo de Hennies et al. (1967) descrevendo o Fa Ihamento de Taxaquara, com rejeito presumido superior a $150 \mathrm{~km}$, fizeram Hasui et al. (1969) voltarem à designação Grupo São Roque para os epimetamorfitos a norte daquele fa lhamento. Não haveria simples continuidade física entre a unidade São Roque e a Açungui e sugeriram que aquele nome de veria ser mantido até que se comprovasse a efetiva correlä ção com o Grupo Açungui.

Os nomes Complexo Cristalino, Migmatítico, Gnáissico e Brasileiro vém sendo usados desde o século passado,incluin do generalizadamente as rochas gnáissicas de toda parte.

Na região de São Paulo, Moraes Rego (1933) conside rou como Complexo Cristalino as litologias gnáissicas. No Es tado do Paraná, Fuck et al. (1967) e Fuck et al. (1971) con sideram-no cono mais antigo e incluindo todos os migmatitos, enquanto os ectinitos pertenceriam ao Grupo Açungui. No Va le do Ribeira, Melcher et al. (1973) mapearam áreas migmatí ticas e, sem diferenciá-las, consideram-nas em parte como in tegrantes do Grupo Açungui e em porte mais antigas, do Pré-Cambriano Médio ou Inferior.

Na área em foco, Moraes Rego (1933) mostrou existir no vale do rio Juquiá uma sequência de xistos, com intercala ções de gnaisses, incluíndo estes últimos no Complexo Crista lino. Para ele, os xistos seriam apenas termos metamörficos mais evoluidos, correlacionáveis com os epimetamorfitos Açun gui. 
1:1.000.000) esses xistos acham-se indicados, mas na legenda foram discriminados à parte, sem pertencerem ao Complexo Cris talino nem ao Grupo São Roque.

A relação entre o Complexo e o Grupo Açungui tem si do objeto de discussão. Moraes Rego (1933), afirmava que o contato nunca é nítido: "há passagens graduais ou são forma ções separadas por granitos posteriores à mais moderna". Melfi et al. (1965) no Vale do Ribeira assinalaram passagens graduais dos ectinitos para os migmatitos, o que Melcher et al. (1973) confirmam.

No Estado do Paraná, Marini et az. (1967) acham que a passagem se dá através de falhas; nos locais onde o conta to parece ser normal, as observações não foram esclarecedo ras. Chamam atenção para a similaridade de estruturas e de grau metamórfico nos dois lados dos presumidos contatos nor mais, dando a entender que seria possível pasisagem gradual.

A relação entre o Complexo e o Grupo São Roque(Hasui et al., 1969) se daria através de enormes zonas de falha. 0 mesmo foi observado por Coutinho (1972) na região de são Paulo.

A tripartição do Pré-Cambriano assim posta, poderia ser reconhecida na área ora estudada. Assim, teríamos os Grupos São Roque e Açungui separados pelo Falhamento de Taxa quara e o Complexo Cristalino incluindo todos os migmatitos descritos ou parte deles.

Todavia, os dados apresentados anteriormente não jus tificam essa tripartição.

0 exame do paleossoma dos migmatitos mostra que ele é essencialmente constituido de metapelitos e metapsamitos, inclusive com alternâncias ritmicas. Intercalações existem de unidades calco-silicáticas, derivadas de antigos sedimen tos calcários impuros ou margas, e unidades metabásicas in troduzidas antes do metamorfismo na sequéncia metapelítical 
/metapsamítica.

0 Grupo Açungui ( no sentido de Marini et al,, 1967) presente na região de Pilar do sul, se constitui essencial mente de metapelitos e metapsamitos, que exibem estratifica ção rítmica. Corpos de rochas calcáries e calco-silicatadas aparecem mais a sudoeste na Folha de Capão Bonito(Bettencourt et al., 1971). Metabasitos existem, intercalados na sequen cia metapelítica/metapsamítica.

No Grupo São Roque (sentido de Hasui et al., 1969) também observamos essencialmente metapelitos e metapsamitos (Fotos l e 2). Rochas calcárjas e calco-silicatadas estão presentes, assim como corpos metabásicos.

Como se vê, em termos litológicos, nentiuma diferença há a se consignar.

Sob o ponto de vista de metamorfismo, observa-se que há um acréscimo de grau ao se dirigjir de norte ou de oeste para sudeste, o que sugere tratar-se de ume feixa metamórfi ca simples.

Quanto ao magmatismo as unjdades presumidas, em nada se diferenciam. Corpos constituícos por "graritos tipo Piri tuba" se distribuem generalizadamente, com as mesmas características.

Geocronologicamente, como veremos adiante, os resul tados disponíveis são concordantes em granitos, anfibolitos, xistos e metabasitos das três entidades. É verdade que ne nhum estudo específico à área foi. feito, mas amostras dela procedentes foram incluídas nos estudos divulgados e não há razões para separar as três unidades.

Sob o ponto de vista estrutural, como veremos há uma diferença entre Açungui e São Roque, mas não entre Açungui e migmatitos. Essa diferença se refere a estilos do dobramen to, mas ela não implica em diferentes unidades estratigráficas. 
Assim sendo, consideramos todas as litologias descri tas sob o nome Grupo Açungui, e assim fizemos constar nos ma pas geológicos anexos.

\section{SUBDTVISOTES DO GRUPO AÇUNGUT}

A subdivisão estratigráfica dos metamcrfitos tem esbarrado com as dificuldades criadas pelas frequentes intru sões, pelos falhamentos, pela variação do grau de metamorfís mo e pelo dobramento complexo.

No Estado do Paraná, Bigarelza e Salamuni (1956, 1958) reconheceram três formaçöes: Setuva, Capiru e Votuvera va. Esse esquema foi mantido pela Comissão da Carta Geológi ca do Parané, com o acréscimo de uma quarta formação, Águas claras (Marini et al., 1967).

A Formação Setuva inclui gnaisses, xistos, quartzitos e raros mármores, metamorfisados em fácies albita-epídoto-an fibolito e anfibolito. Não se sabe ao certo se suas rochas "estão mais intimamente associadas aos migmatitos que ocor rem a sudeste dia área de distribujção do Grupo Açungui, do que propriamente às sequencia superiores desse grupo" (Mar ni et al., 1967). Ebert (1971) acha que a parte basal des sa unidade não faz parte do Grupo Açungui e denominou-a Pré- Setuva. No topo, a Formação setuva passa gredualmente para a Formação Capiru. Fuck et a.l. (1971) acham que a Formação toda talvez tenha se formado num ciclo mais antigo do que o que gerou o Grupo Açungui.

A Formação Capiru constitui-se de dolomitos interdi gitados com quartzitos e filitos, metamorfisados em fácies xisto verde. Contém estruturas relacionadas a algas. No to po, ela é coberta discordantemente pela formação Votuverava, mas inversões são reconhecidas e atribuidas a falhas.

A Formação Votuverava, a mais espessa, constitui-se de filitos e subordinadamente calcários quartzitos e conglo 
merados, metamorfisados em fácies xisto verde. No topo, é sobreposta pela Formação Águas Claras através de aparentedis cordância. A última formação se constitui de calcários e fi to-calcários.

Marini et al. (1967) procuraram associar as

forma ções com o esquema de Beloussov (1962). A Fornação Setuva corresponderia à sequência terrígena inferior, enquanto a Ca piru seria a sequência carbonatada. A sequência terrígena superior compreenderia as Formações Votuverava e Aguas ras.

No Vale do Ribeira, Melcher et al. (1973) reconheceram uma discordância angular entre as Formação Setuva e Capi ru, mas, de resto, os contatos seriam tectônicos. Nos mapas referentes ao Projeto Ribeira foram divulgados, em escala de 1:200.000, por Melcher et al. (1971), Bettencourt et al. (1971) Gomes et al. (1971), Cordani et al. (1971), Cordani (1971a) e Gomes et al. (1971a) e neles não é feita a subdivi são estratigráfica.

Nos metamorfitos a norte do Falhamento de Taxaquara, Hasui et al. (1969) consideraram difícil a subdivisão pela falta de horizontes-guia contínuos e pela dominância de meta pelitos intensamente deformados que impossibilitam a recons tituição das estruturas.

Y. Hasui, W.T. Hennies, G.R. Sadowski e G.F. Fuck (inédito), em investigação mais detalhada na área do sindinó rio de Pirapora, entre Araçariguama e Caieiras, julgam que as ocorrências calcárias lenticulares, entremeadas em metape litos, configuram um nível estratigráfico. Já Moraes Rego (1933) achara que os calcários corresponderiam a um horizon te repetido no terreno graças ao tectonismo. Abaixo dele si tuam-se filitos e lentes de quartzito, tão possantes quanto as que sustentam o Morro do Boturuna. Acima aparecem metape litos e metapsamitos em sequência rítmica. O metaconglomera do reconhecido por Hasui et al. (1969) na Estrada de Itu ló 
calizar-se-ie na base desse pacote superior. Se considerar mos o modelo de Bezoussov (1962), as três sequências citadas teriam correspondência com a terrígena inferior, a carbonata da e a terrígena superior. Faltam as sequencias lagunar e de molassa.

Dentro dessa ordem de idéias, ao se examinar à volta do Maciço de São Roque, podemos observar a sequência carbona tada em posição proximal. Corpos isolados de rochas calcosi licatadas no interior do macico foram constatados por J. $S$. Bettencourt (comunicação pessoal). Distalmente, os metapeli. tos e metapsamitos rítmicos tém franco desenvolvimento (Fo tos 1 e 2 ).

No canto nordeste da Folha de São Roque, a sequencia calcária (rochas calcossilicatadas descritas anteriormente, calcário da Pedreira Santa Rital recobrem metapelitos da se quência terrígena inferior. Estes reaparecem a sul de Araça riguama.

Na região de Pilar do Sul observam-se, na maior par te da área, metapelitos e metapsamitos da sequência superior, caracterizada pelo ritmismo de camadas e lâminas. Eles são atribuiveis à Formação Votuverava e transicionam para os xis tos a leste de Pilar do sul, os queis corresponderiam à For mação Setuva. Falta aí a sequência carbonateda.

Cumpre lembrar que os estudos em sequencias geossin clinais, sobretudo nas olpinas, mostram que a subsidência não se dá de modo uniforme nem continuamente em toda a faixa lá bil. Auboin (1965) acha que hé um poleridade desses movimen tos de tal. sorte que es sequências depositadas são unidades litoestratj.gráficas discordantes com unidades cronogeológicas. Nessas condições, não é possivel considerar-se as sequências em termos de simples superposjção. Aliás, Petri e suguio (1969), após minucioso estudo no Vale do Ribeira, sugerem con temporaneidade e interdigitações entre as Formações Votuvera 
va e Capiru-Itaiacoca.

No tocante a contatos entre sub-unidades, ainda há que se lembrar o quase absoluto predominio de metapelitos, que são rochas incompetentes na deformação. As intercala ções competentes têm extensões e espessuras as mais variadas. As mais espessas se deformam e impõem seu estilo às rochas incompetentes adjacentes. As mais delgadas antes de imposi ção, passam a se comportar como subordiandas (Beloussov, 1962). Dentro de um contexto de deformação como esse, difícil é cons tatar-se a existência de discordâncias.

Quanto às espessuras, só podemos medi-las localmente em camadas competentes, que são simples intercalações. o do bramento complexo de uma sequêricia essencialmente metapelíti ca não possibilita sequer avaljações de espessuras. As cita ções de 5000 a 7000 m no Paraná (Marini et c.l., 1967) não foram confirmadas por Petri e Suguio (1969) no Vale do Ribei ra. Na área aqui focalizada parece que espessuras bem meno res que aqueles valores são suficientes para explicar as fei ções observadas.

Até agora nos referimos a rochas epimetamorfisadas. Se adentrarmos na área dos mj.gmatitos, a recoristituição es tratigráfica se vê dificultada, exigindo investigações por menorizadas.

Como vimos, é possível em termos gerais reconhecer- se sequências. Todavia, seus limites não foram ainda esta belecidos com precisão de modo à possibilitar o mapeamento. Por isso, nos mapas geológicos anexos consideramos todos os metamorfitos como compondo o Grupo Açungui, sem introduzir subdivisões.

\section{AMBIENTE DE SEDIMENTAÇÃO}

Há um consenso geral quanto às condições marinhas do ambiente de sedimentação. A extensão das camadas, a unifor 
midade litológica por extensas áreas, a existência de rochas carbonáticas organógenas e muitas outras feições descritas por Marini et al. (1967) e Petri e Suguio (1969) não deixam dúvidas quanto a essas condições.

Marini et al. (1967) acham que ambiente nerítico pre valeceu ao tempo de deposição das Formações Capiru e Águas Claras, face à presença de rochas calcárias com indicios fos silíferos, bem como associação da primeira formação com quart zitos, presença de pisólitos e outras feições. Já no tempo de acumulação da Formação Votuverava, a costa estaria mais distante, daí o aparecimento de feições relacionáveis a cor rentes turvas (estratificação cruzada, gradual e rítmica,etc.).

Petri e Suguio (1969) concluiram no sul do Estado de São Paulo, que a sedimentação se deu em profundidades crescen tes de NW para SE, quando da deposição das sequências terrígé na inferior e carbonatada.

As espessuras acumuladas, o dobramento e metamorfismo das camadas e o magmatismo associado são características de faixas dobradas resultantes de evolução de geossinclíneo (A $\underline{u}$ boin, 1965; Beloussov, 1962). Em 1964, Almeida chamou-o Geos sinclíneo Paraíba e, mais recentemente, Almeida et al. ( no pre (o) denominam Faixa Dobrada do Ribeira, resultante da evo lução de um ortogeossinclíneo no Ciclo Brasiliano. 


\title{
CAPITULO 8 - ANÁLISE DAS ESTRUTURAS
}

\author{
ESTRUTURAS RELIQUIARES
}

A estratificação dos antigos sedimentos acha-se bem preservada nos ectinitos. Ela se manifesta claramente atra vés de diferenças de granulometria, de texturas, de cor e de composição mineralógica, em todas as rochas metassedimentares.

Laminação cruzada é vista em pequena escala nos lei tos de metapelitos, do tipo tangencial, em co-sequências iso ladas. Estratificação cruzada do tipo diagonal, em camadas de alguns decímetros de espessura, aparecem ocasionalmente em quartzitos. Por vezes, em lâminas metapelíticas vêem-se on dulações regulares, que lembram marcas de onda.

Tais particularidades das camadas tendem a ser obli teradas com o incremento da recristalização metamórfica. As sim, no paleossoma dos migmatitos somente a estratificação ainda pode ser distinguida.

Destaque merece a já descrita ritmicidade observada em grande parte dos metassedimentos (Fotos l e 2). Participam desse ritmismo ou ciclismo:

1 - camadas metapsamiticas, sem estrutural gradual;

2 - camadas e lâminas metapsamíticas e metapsamíti cas argilosas alternadas (Foto 2);

3 - lâminas e camadas alternadas metapelíticas, mais e menos quartzosas ou grafitosas (Foto l);

4 - camadas metapelíticas.

São observáveis sucessões com $1-2,3-4,2$ e 3 nos ectinitos. Nos migmatitos somente as duas últimas são vistas.

Tal característica, de acordo com Bouma (1962) e 
Dzulynski e Walton (1965) é típica de depósitos de "flysch".

Petri e Suguio (1969) descreveram sequências rítmi cas ou cíclicas no sul do Estado de São Paulo, bem como es truturas internas, que permitem considerar aqueles metassedi mentos como depósitos de "flysch". Lá, eles se superpõem aos calcários.

Esta mesma superposição é clara no Bloco são Roque ou, como diz Beloussov (1962), a sequência terrígena supe rior cobre a sequência carbonatada e é caracterizada pelo de senvolvimento de "flysch".

\section{ESTRUTURAS TECTOGGENAS}

\section{FALHAS}

Nos Capítulos anteriores já nos referimos às proemi nentes zonas de falhamento transcorrente de Taxaquara, Pira pora, São Roque e Caucaia.

- intenso metamorfismo cataclástico produziu rochas com uma foliação conspícua, orientada segundo a direção. ge ral da zona de falhamento e com mergulhos de 70-90 para um e outro sentido, o que mostra o caráter não planar da faixa. Graças à fissilidade dessas rochas, nas superfícies de dis junção observamos uma lineação bem desenvolvida constituída pela moínha de minerais fragmentados (Foto 7). Essa linea ção é paralela à direção geral do falhamento, mas tem incli nações de $0^{\circ}-20^{\circ}$ para um outro sentido, indicando que as fa tias individuais de rocha isoladas pelos planos de cisalha mento não se deslocaram uniformemente.

0 sentido dos movimentos não pôde ser determinado di retamente ao longo das zonas de cataclase ou adjacências. Os desvios de direções de dobramentos nos metamorfitos que se vêm no canto noroeste da Folha de São Roque e também a E-NE 
de Pilar do Sul não têm vinculação com os falhamentos,

mas com as intrusões granitóides.

Hennies et al. (1967) com base no esquema de Moody e Hizl (1956) e considerando o Falhamento de Taxaquara como de primeira ordem, concluiram por seu caráter dextral e es forços principais segundo E-W.

Moody e Hill (1956) examinaram detidamente o sistema de falhamentos da costa oeste norte-americana e elaboraram um esquema geométrico de distribuição de falhamentos de vá rias ordens, que poderiam ser explicados por um esforço prín cipal N-S (Figura 8). A inferência desses autores quanto à universalidade de esforços $\mathrm{N}$-S mostrou-se inconsistente, mas - esquema parece ser válido (Badgley, 1965).

No caso presente, o esquema pode ser perfeitamente aplicado e as falhas conhecidas apresentam concordância com as previstas, como se vê na Figura 9 , e só uma possibilidade é viável. Os ângulos são medidos entre segmentos das falhas não próximos às zonas de junção. Assim, o Falhamento de Taxaquara é de primeira ordem e dextral, o de pirapora é de segunda ordem e sinistral, o de Caucaia é de terceira ordem e dextral e o de São Roque é de segunda ordem e dextral.

Quanto ao rejeito desses falhamentos, não se obser vou ainda possibilidade de justaposição de eventuais corpos bipartidos. Tal levou Hennies et al. (1967) a considera rem $150 \mathrm{~km}$ como valor mínimo de rejeito para o Falhamento de Taxaquara.

Quanto à idade dos falhamentos, são eles seguramente pré-Tubarão e pós-granitos pós-tectônicos (Hennies et al., 1967). Se considerarmos como Almeida (1969) que já no Silu u riano imperavam condições ortoplataformais, parece aceitável limitar esses falhamentos ao Cambro-ordoviciano, quando as condições eram de paraplataforma. 
Fig. 8 - ESQUEMA DE MOODY E HILL. (CF. BADGLEY, 1965)

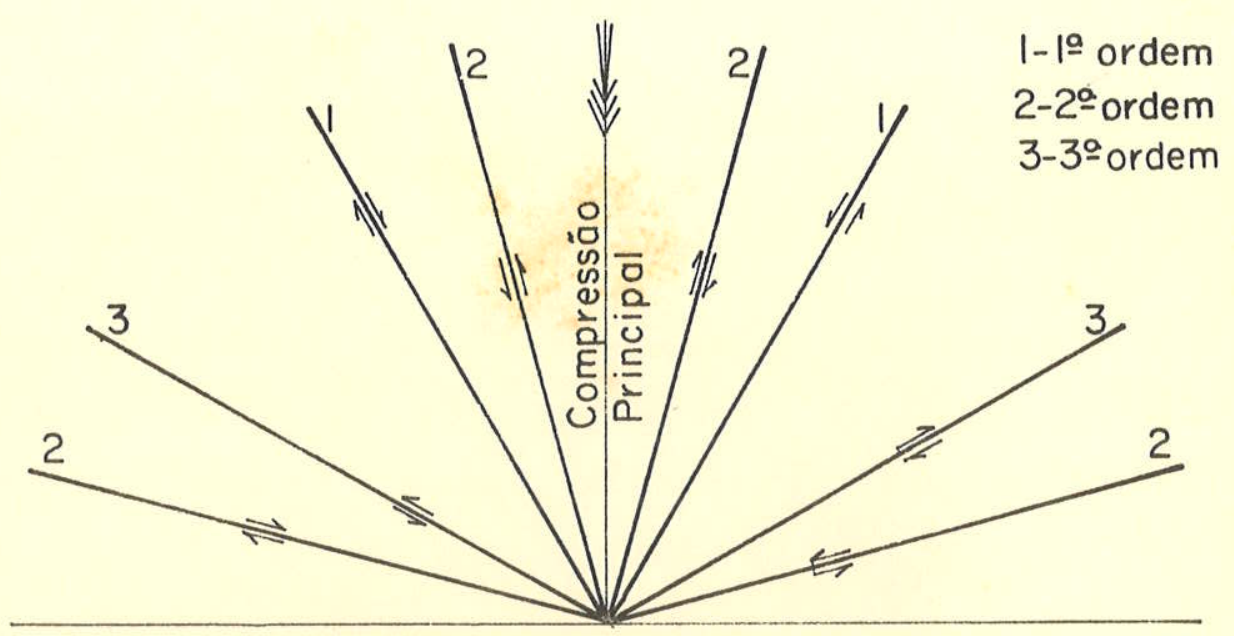

Fig. 9 - MOVIMENTOS RELATIVOS DOS FALHAMENTOS DA ÁREA
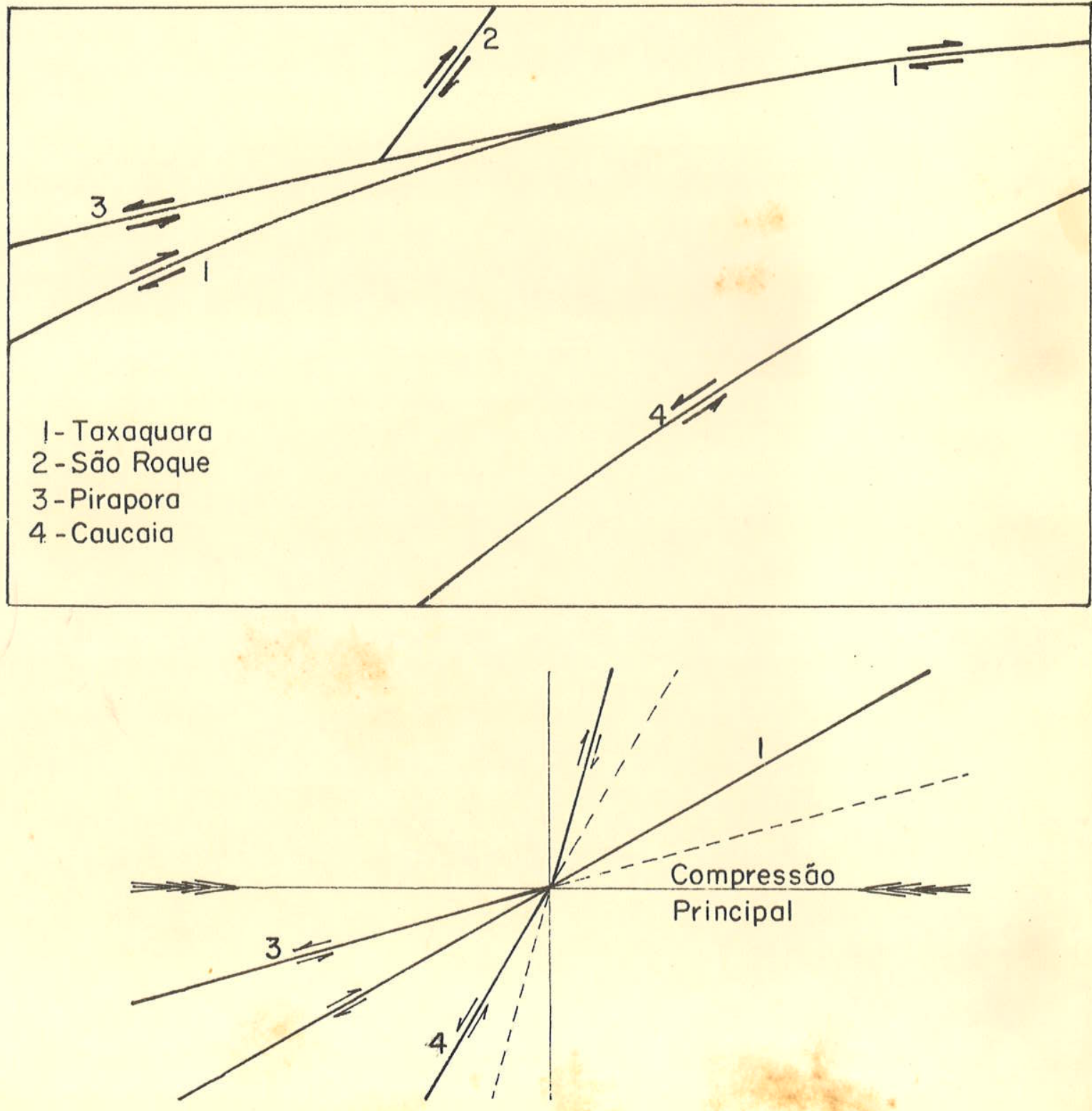
respeito à relação entre os falhamentos de Taxaquara e Cau caia com as ocorrências de sedimentos terciários.

0 Falhamento de Taxaquara estende-se para leste, pas sando por Barueri e chegando às faldas da Serra da Cantareira (Hennies et al., 1967); daí se prolonga até a região de Mogi das Cruzes (Coutinho, 1972) em parte marcando o limite nor te da Bacia Sedimentar de São Paulo.

0 Falhamento de Caucaia teve seu prolongamento obser vado por Y. Hasui, G.R. Sadowski, G.F. Fuck, O.R. Obata e C. R. Carneiro (inédito) até a região de Taboão da Serra, com tendência rumo ao centro da Capital. paulista, passando a 1,5$-2,5 \mathrm{~km}$ a sul da Cidade Universitária. Em conexão com esse fato, as seguintes observações podem ser feitas:

1 - Leinz e Carvalho (1957) assinalam um acentuado desnível. topográfico na região central da Capital paulista;

2 - Kollert e Davino (1963) verificaram por métodos geofísicos a existência de desniveis abruptos que atribuiram a uma tectônica de blocos;

3 - Coutinho (1972) reconheceu o que chamou de Faixa Gnáissica Intermediária e que corresponde ao Bloco Cotia aqui descrito. Essa faixa se expõe em manchas nos bairros de Cam pos Elíseos, Ferdizes e Pacaembu. O limite sul da Faixa se ria uma linha que corresponde exatamente ac Falhamento Cau caia aqui descrito.

Parece, então, que o Falhamento de Caucaia termina de encontro ao Falhamento de Taxaquara, dando ao Bloco Cotia a forma de cunha. Essa zona de junção estaria na altura de Santana e dali para nordeste outros falhamentos já foram re conhecidos (Coutinho, 1972; Almeida, 1955). Aparentemente, a Bacia de São Paulo se implantou en uma zona de convergência de falhamentos e não é estranho considerar-se uma origem tẹ tônica, como sugerido por Freitas (1951).

Quanto às manchas esparsas de sedimentos terciários 
a oeste de São Paulo, Hasui et al. (1969) admitiram reativa ções de falhas antigas para explicar sua distribuição. Situa ção análoga se verifica no Bloco Cotia como já enunciamos an tes, sugerindo seu abatimento. Todavia, como frisamos, um controle litológico da drenagem também pode explicar aquela distribuição mostrada na Figura 7.

Além desses enormes falhamentos, aparecem por toda área falhas pequenas, com faixas milimétricas ou centimétri cas de rochas cataclásticas associadas. Na maior parte, por suas atitudes, parecem vincular-se aos sistemas de juntas de cisalhamento que descreveremos em seguida. Os rejeitos são desde submilimëtricos até decamétricos. Uma falha de certo porte parece existir no Vale do rio São Lourenço, que teria promovido o desvio das estruturas dos migmatitos.

\section{JUNTAS}

As observações em afloramentos mostram que sistemas subverticais (Foto 8 ) e subhorizontais de juntas estão sem pre presentes nas áreas de metamorfitos. Constata-se ainda no terreno que vales e cristas retilíneos têm orientação em grande parte concordantes com os sistemas subverticais.

Para uma definição mais precisa desses sistemas de juntas, escolhemos quatro áreas sobre o mapa de lineamentos fotogeológicos que pudessem ser consideradas homogêneas e ne las efetuamos estudos estatísticos. A Figura 10 mostra essas áreas, designadas $1,2,3$ e 4 para facilidade de exposição. Os resultados estão representados nas Figuras 11, 12, 13 e 14, respectivamente para essas áreas. Os diagramas são do tipo $\pi$, isto é, representam projeções de polos das normais aos planos no hemisfério inferior da esfera de referência, usando o reticulado de Schmidt-Lambert (igual área). Os polos não se acham representados, mas as densidades de distrí 


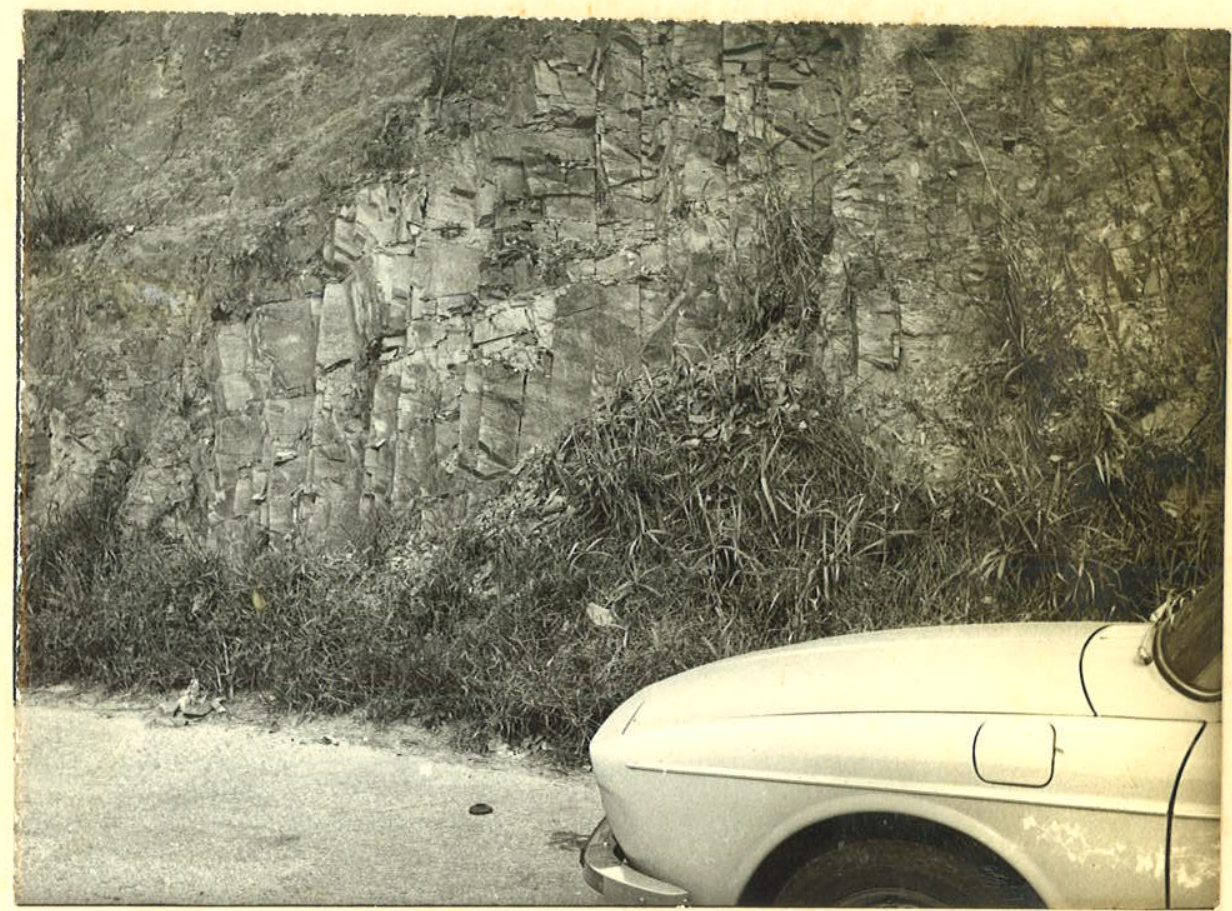

FOTO 8 - Sistemas de juntas em quartzito. O sistema subver: tical mostrado é perpendicular à xistosidade; nota-se também um sistema de baixo mergulho. Rodovia Raposo Tavares, $\mathrm{km} 83$, a $3 \mathrm{~km}$ de Brigadeiro Tobias para Alumínio. 
Fig. IO-DOMINIIOS HOMOGÊNEOS ESCOLHIDOS PARA ANÁLISE ESTRUTURAL

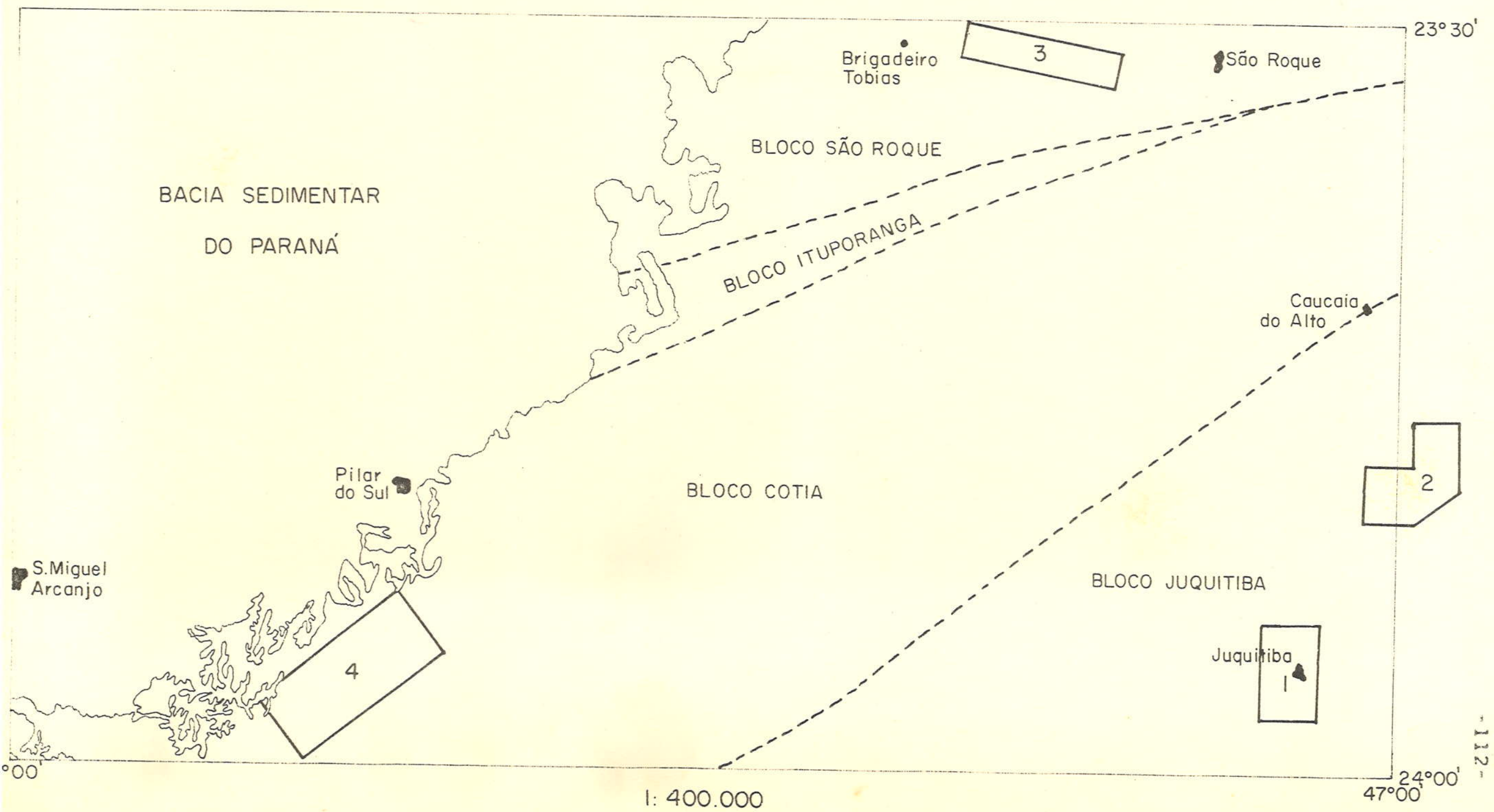


Fig. II - DIAGRAMA $\Uparrow$ DE JUNTAS DA ÁREA I

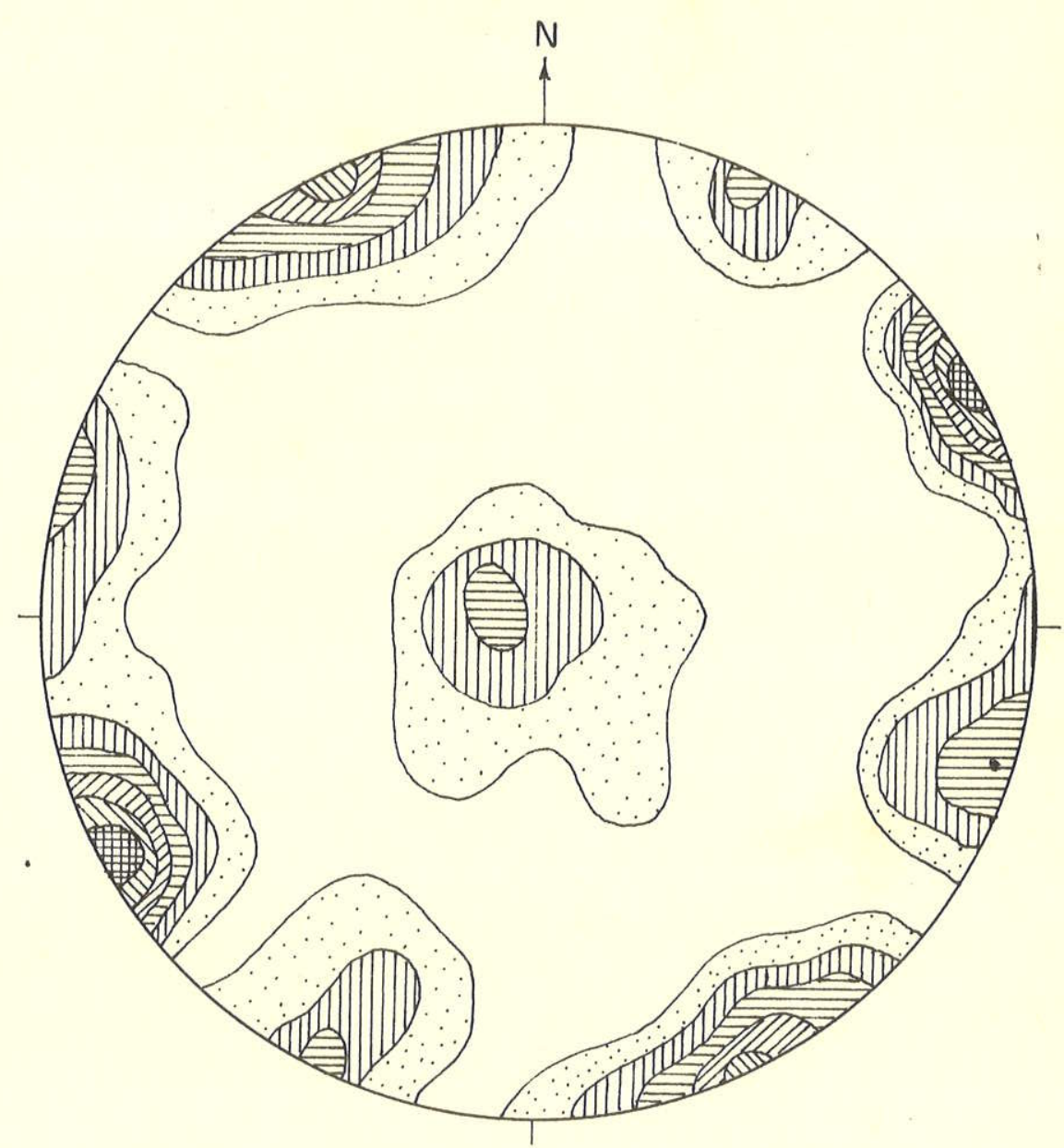

530 polos

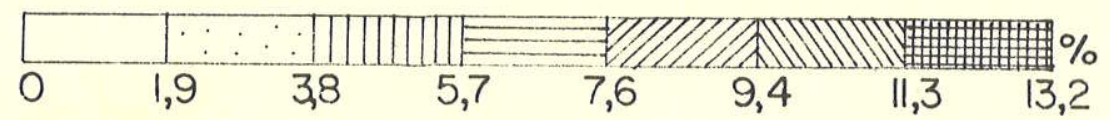


Fig. 12 - DIAGRAMA $\pi$ DE JUNTAS DA ÁREA 2

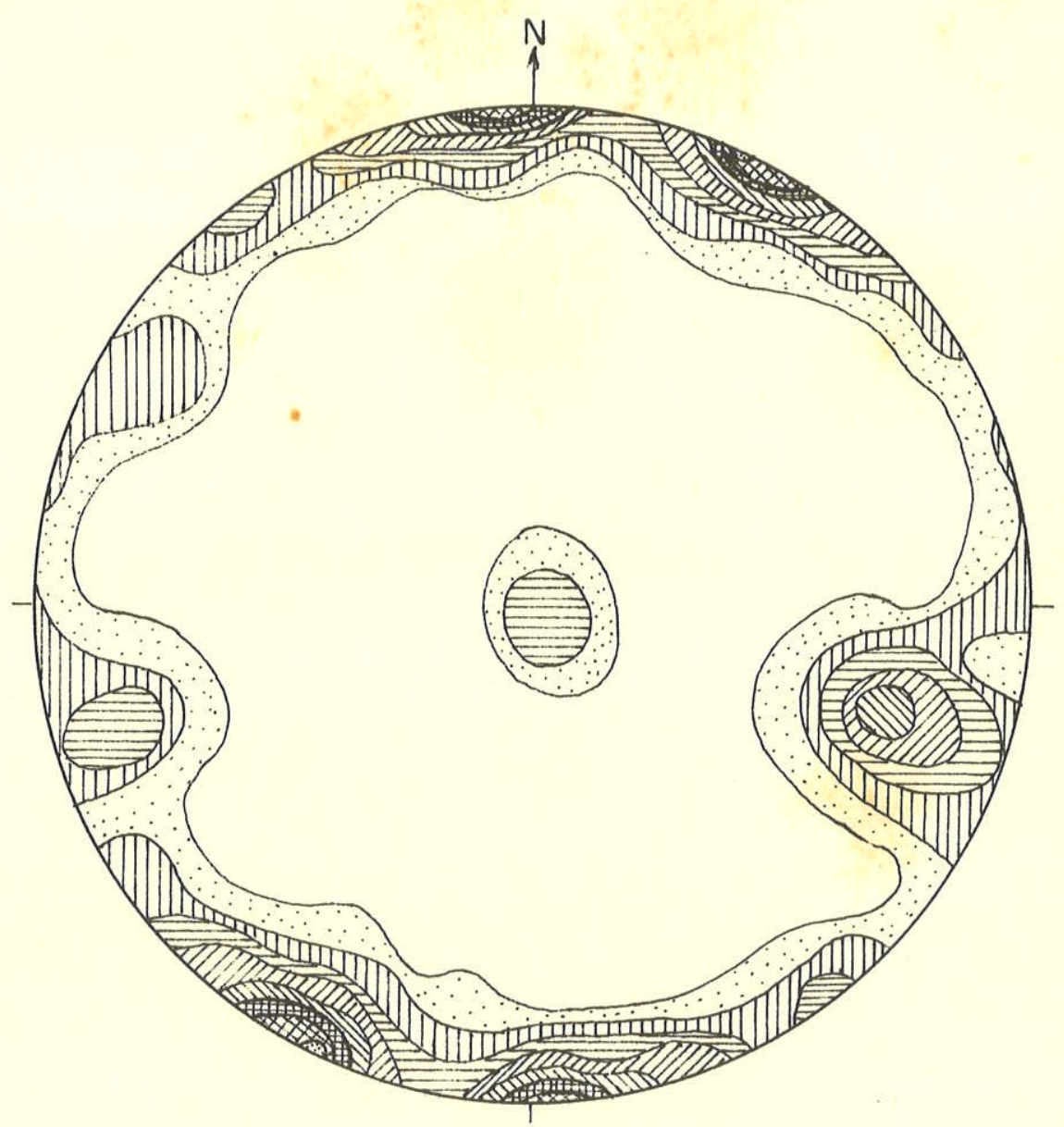

334 polos

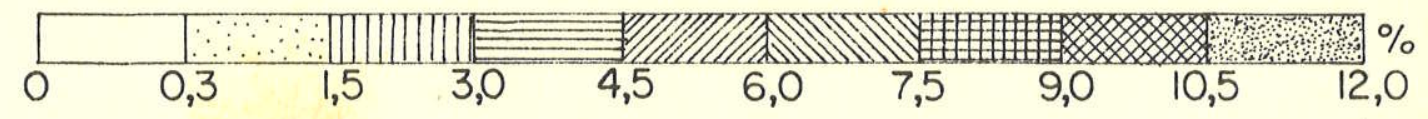


Fig. 13 DIAGRAMA $\pi$ DE JUNTAS DA ÁREA 3
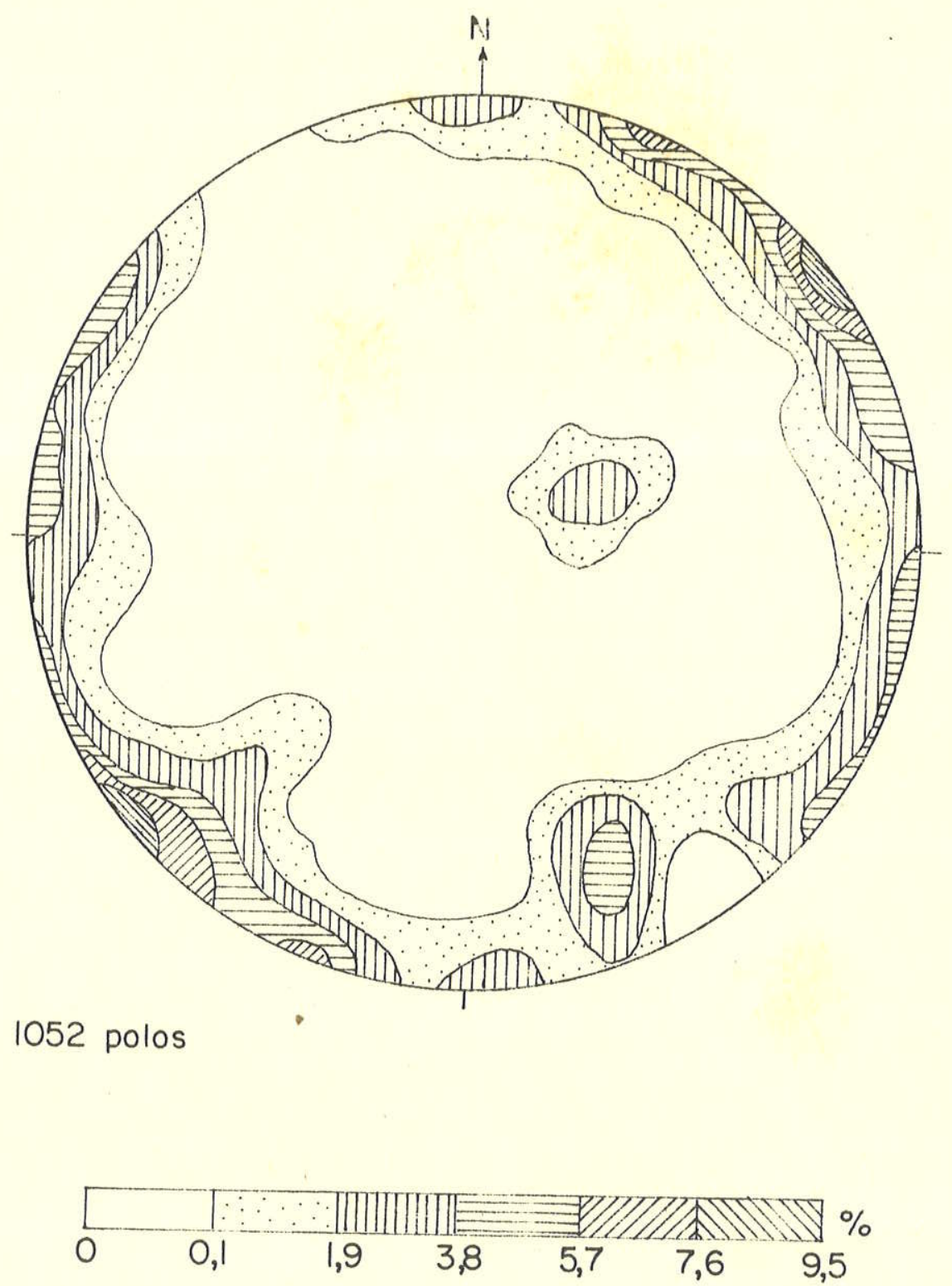
Fig. 14- DIAGRAMA II DE JUNTAS DA ÁREA 4
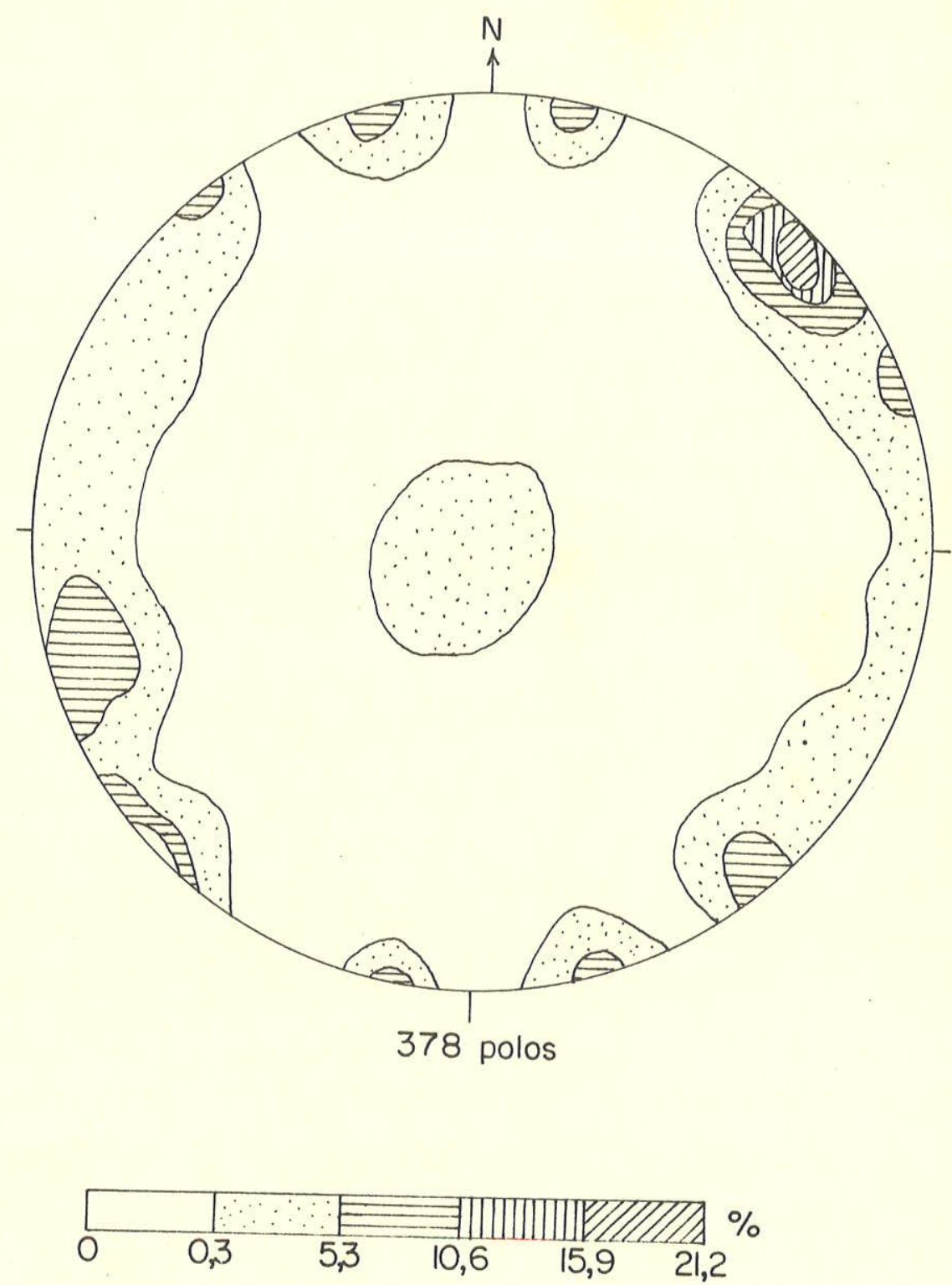
buição estão indicadas pelas curvas de isofrequência.

Embora com diferenças de aspecto, em todos os quatro diagramas observamos a presença de um sistema de juntas sub horizontais e quatro sistemas subverticais.

A Tabela 15 mostra as atitudes preferenciais de cada um desses sistemas.

A qualificação dos sistemas podemos fazê-la após exa minarmos outros tipos de estruturas.

\section{XISTOS IDADE}

Por xistosidade entende-se aqui a orientação planar de minerais placóides ou prismáticos e de agregados de grãos (Billings, 1954). Corresponde às foliações plano-axial e pa ralela à estratificação de Whitten (1966), à clivagem de flü xo e à clivagem ardosiana de outros autores. Ela se desen volve por metamorfismo dínamo-termal.

A xistosidade aparece de maneira destacada nas ro chas metapeliticas, mas em outros tipos litológicos também é observável, graças a grãos de quartzo achatados e a pequenas quantidades de micas.

Nas äreas 1, 2, 3 e 4 (Figura 10) foram realizados estudos estatísticos.

Na área l, a xistosidade se apresenta coincidente com a antiga estratificação, no paleossoma dos migmatitos. o aca mamento, como já dissemos, é visível graças à alternância de metapelitos de diferentes texturas, cor, composição ou granu lação e à alternância de camadas de metapelito e metapsamito. As atitudes no diagrama $\pi$ definem uma guirlanda (Figura 15), indicando que ambos, a xistosidade e o acamamento, formam do bras cilindricas.

Na área 2, também há coincidência de xistosidade e acamamento reliquiar e o diagram $\pi$ (Figura 16) é análogo ao 
TABELA 15

SISTEMAS DOMINANTES DE JUNTAS

Ârea

1

2

3

4

\begin{abstract}
Sistema principal
\end{abstract}
N3OW BBNE (T)

NI7E 73NW (O)

N38W vert (T)

N43W 84SW (T)
Sistemas subordinados

NG4E B8SE (P)

NIGE $87 N W(0)$

N65W vert (0)

NI2E OBSE (H)

NI7W 76NE (T)

N87E vert (O)

N64W vert $(P)$

N4OE O3NW (H)

N67E 68NW (P)

N68W vert (O)

N2OE vert (O)

N23W $245 W(H)$

N5OE $82 N W(P)$

NI5W 82NE (O)

N8OW 89SW (0)

N43W O4NE (H)

T - Sistema transversal à xistosidade.

P - Sistema subparalelo à xistosidade.

0 - Sistema oblíquo à xistosidade.

H - Sistema subhorizontal. 
Fig. 15 DIAGRAMA $\pi$ DE XISTOSIDADE E ACAMAMENTO RELIQUIAR COINCIDENTES DA A'REA I

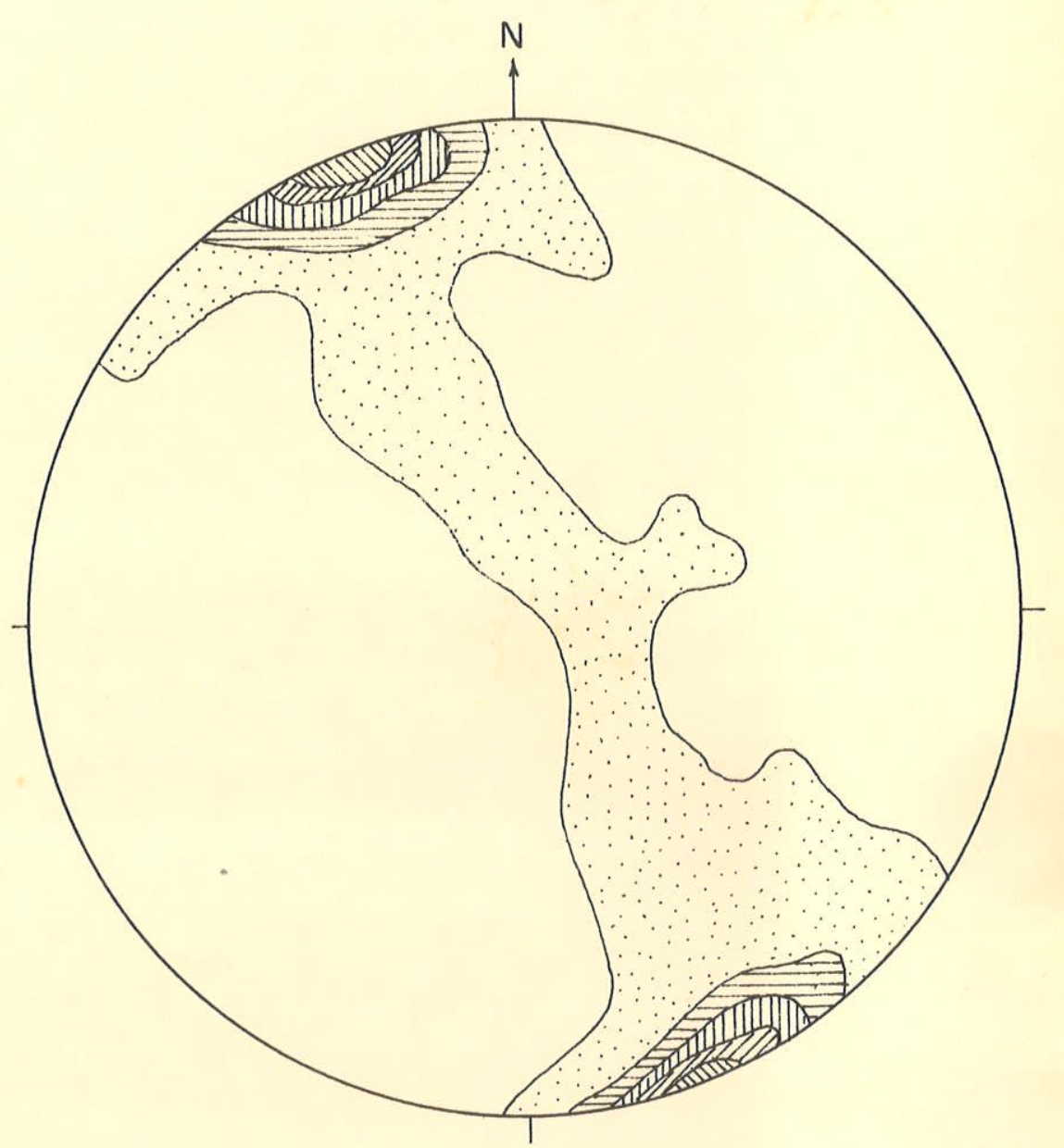

196 polos

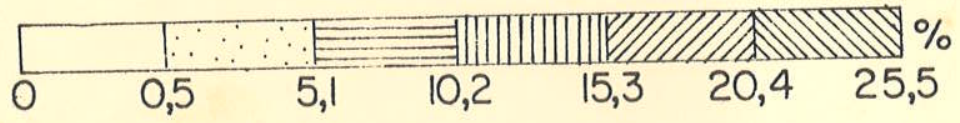


Fig. - 16 DIAGRAMA $\pi$ DE XISTOSIDADE E ACAMAMENTO RELIQUIAR CONCORDANTES DA ÁREA 2

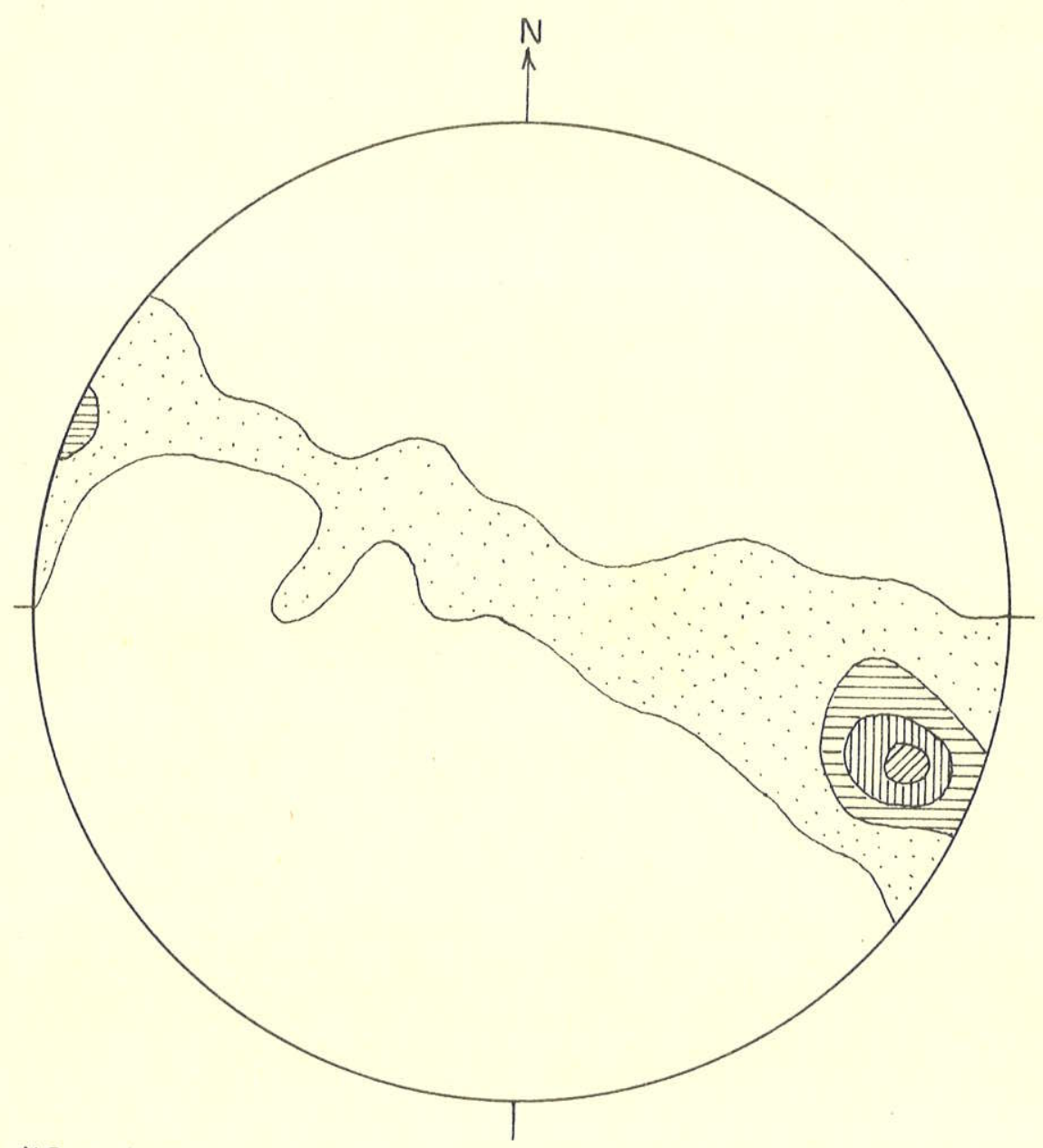

112 polos

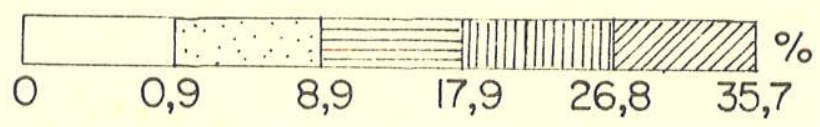


da área anterior, diferindo apenas na orientação da guirlan da. Tais diagramas são idênticos àqueles apresentados por Coutinho (1972) para a região de Itapecerica da Serra/Embu/ /Represa de Guarapiranga.

Na área 3, a xistosidade e o acamamento são concor dantes em muitos afloramentos e discordantes em outros (Fo to 9). O diagrama $\pi$ da Figura 17 refere-se à estratificação reliquiar, notando-se que ela delineia uma guirlanda, que traduz dobras cilíndricas. O diagrama $\pi$ da Figura 18 corres ponde à xistosidade; é ele do tipo axial e indica que a xis tosidade tem atitude plano-axial nas dobras.

$\mathrm{Na}$ área 4, a xistosidade e o acamamento se apresen tam coincidentes e o diagrama $\pi$ da Figura 19 mostra que defí nem uma guirlanda, tal como nas áreas 1 e 2.

Na Tabela 16 são apresentadas as atitudes dos eixos das guirlandas e as atitudes dominantes da xistosidade. Os eixos das primeiras são eixos $\beta$ que devem corresponder a ei xos b ou B (lineações paralelas aos eixos das dobras e eixos reais das dobras). As atitudes dominantes da xistosidade nos fornecem os sentidos da vergência (Aubcin, 1965).

TABELA 16

EIXOS DE GUIRLANDAS E ATITUDES DOMINANTES DE XISTOSIDADE

$\begin{array}{ccc}\text { Área } & \text { Eixo da guirlanda } & \text { Xistosidade } \\ 1 & \text { N70E 07SW } & \text { N70E 89SE } \\ 2 & \text { N22E 08SW } & \text { N22E 74NW } \\ 3 & \text { N58E 15SW } & \text { N58E 83NW } \\ 4 & \text { N53E } 04 \mathrm{SW} & \text { N53E 84NW }\end{array}$




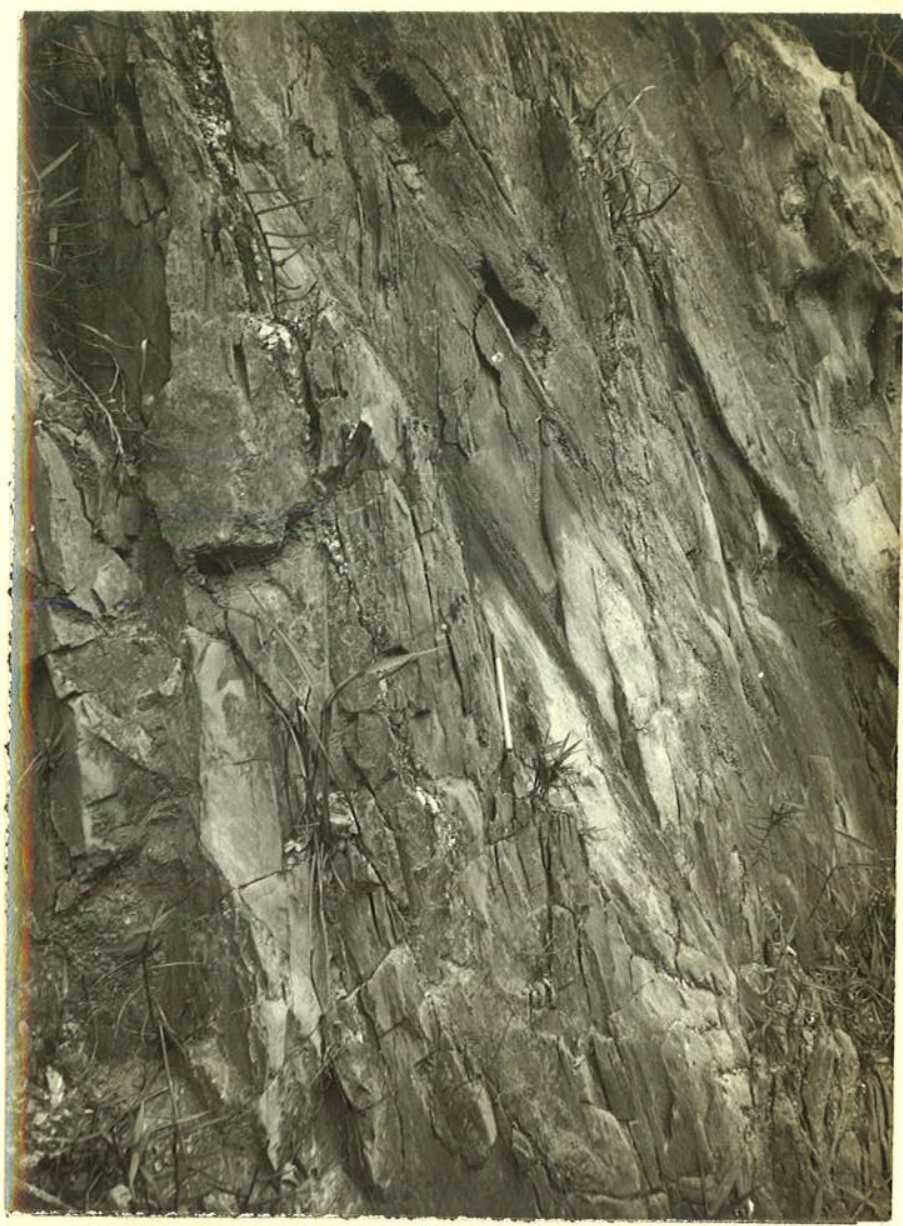

FOTO 9 - Xistosidade subvertical discordante com a estratificação mergulhando fortemente para a direita. Rodovia Raposo Tavares, km 82, a $4 \mathrm{~km}$ de Brigadeiro Tobias para Alumínio. 
Fig. 17 - DIAGRAMA $\pi$ DO ACAMAMENTO DA ÁREA 3

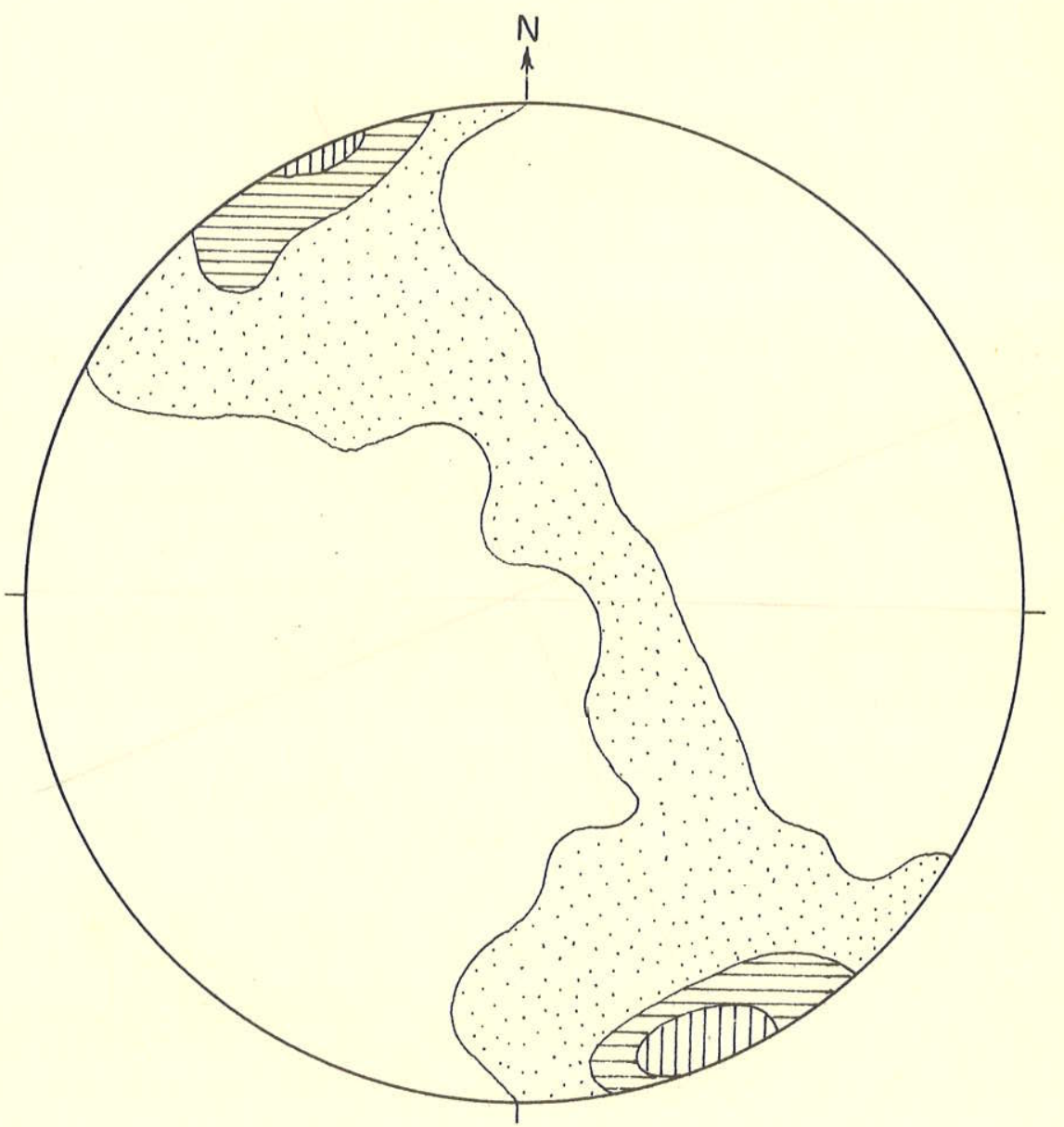

145 polos

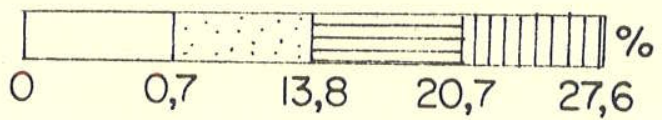


Fig. 18 - DIAGRAMA $\pi$ DE XISTOSIDADE DA ÁREA 3

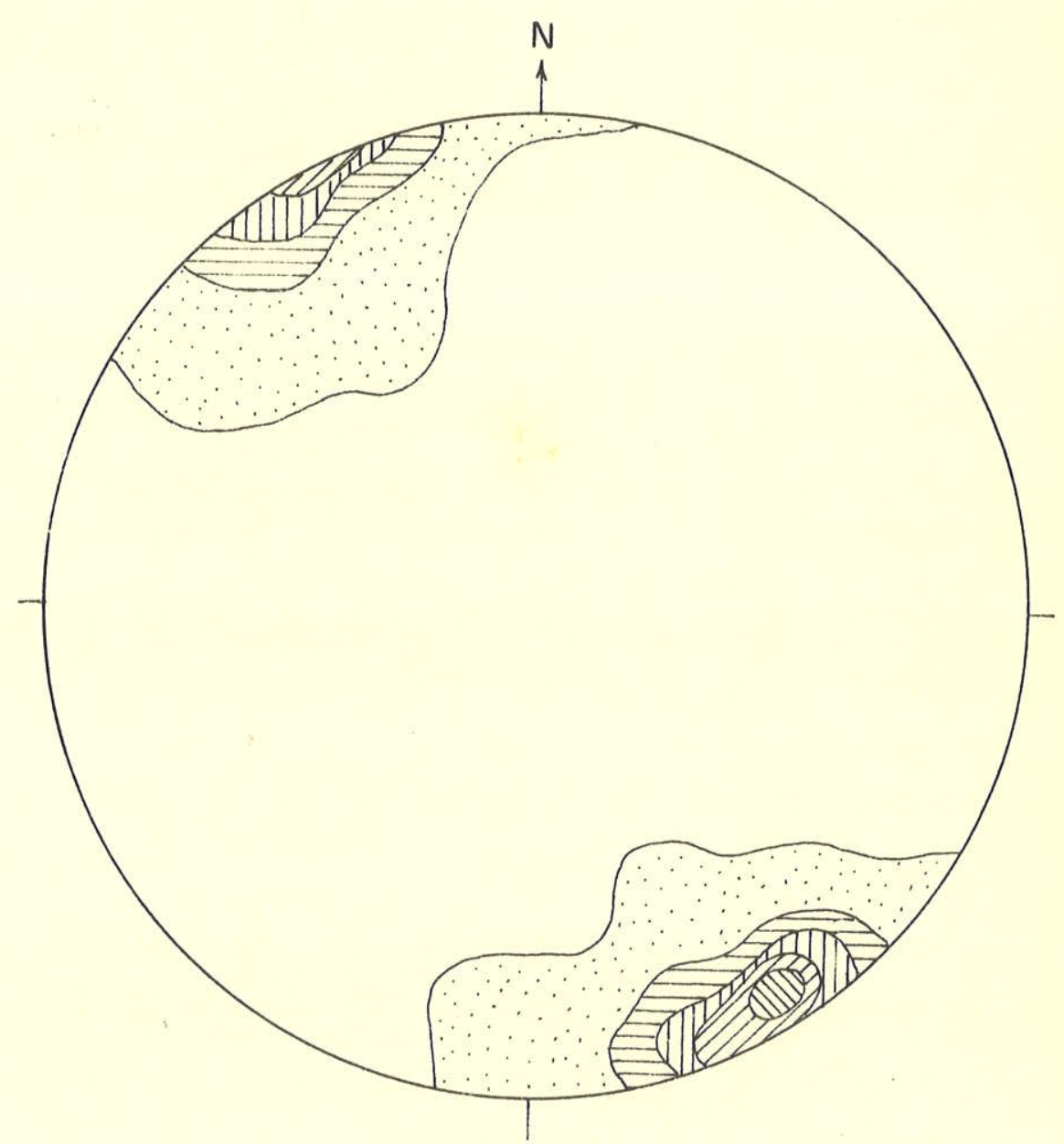

150 polos

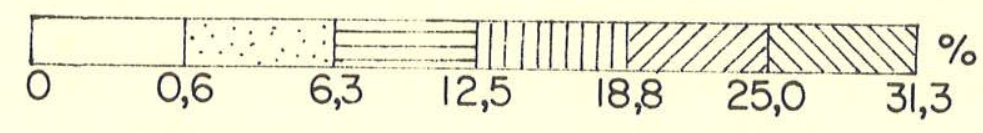


Fig. 19 DIAGRAMA $\pi$ DE XISTOSIDADE E ACAMAMENTO RELIQUIAR COINCIDENTE DA A'REA 4

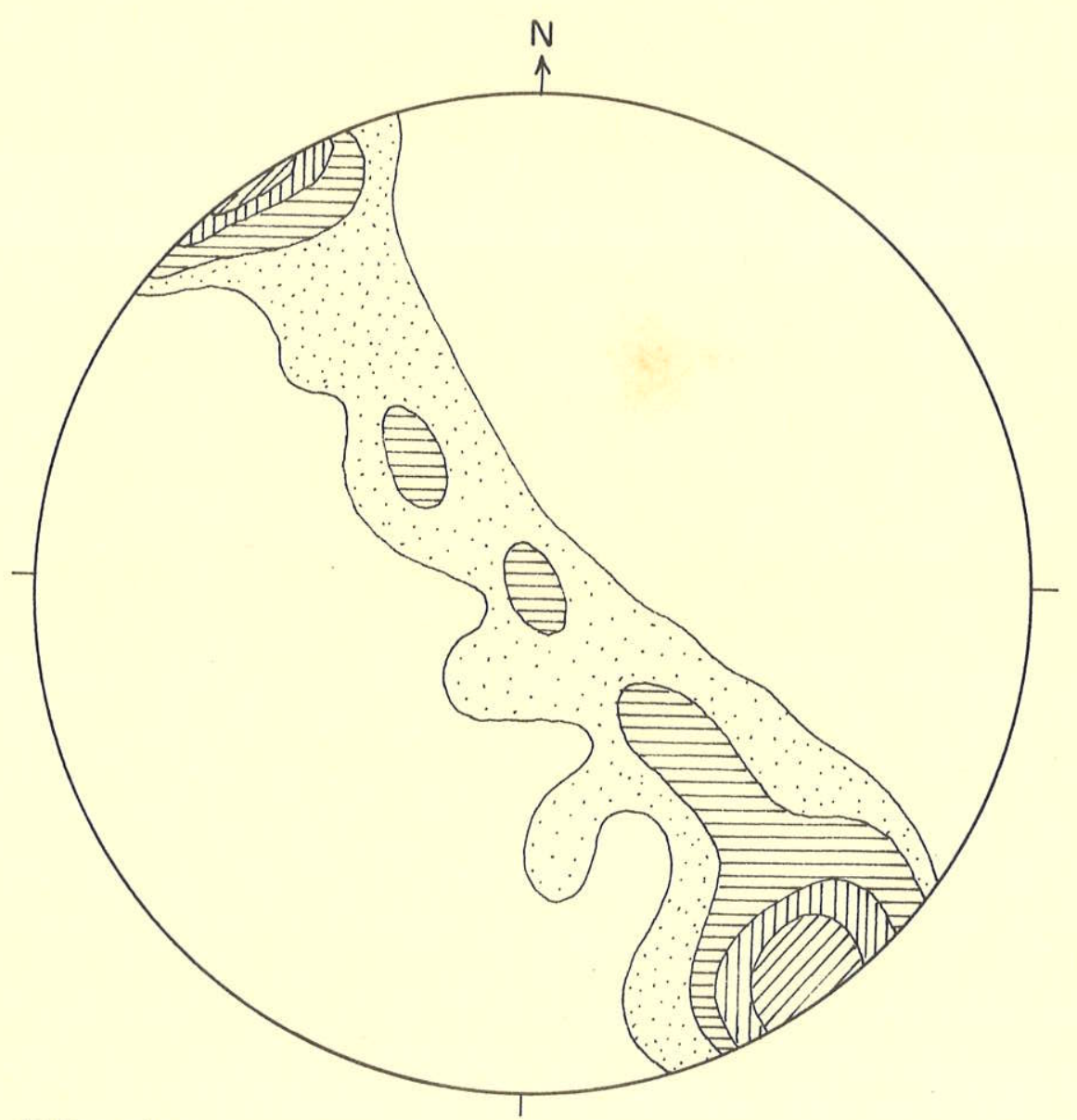

122 polos

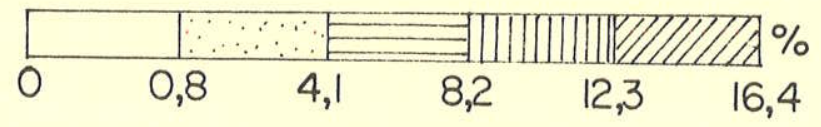


As Figuras 20, 21 e 23 são diagramas representando planos axiais das dobras e atitudes de seus eixos. (diagramas combinados de $\pi$ e $B$ ), e dizem respeito às áreas 1,2 e 4 , res pectivamente. A Figura 22 refere-se à área 3; é um diagrama combinado de $\pi$, B e b, representando planos axiais das do bras, eixos de dobras (B)e lineações paralelas a eixos de do bras (b).

Confrontando-se as atitudes dos eixos das guirlandas (Tabela 16) com as atitudes dos eixos de dobras vemos que há concordância perfeita; as dobras são subhorizontais.

Se confrontarmos as atitudes dominantes da xistosida de da Tabela 16 com as atitudes dominantes de planos axiais de dobras, vemos também perfeita concordância.

0 paralelismo entre a xistosidade e a estratificação reliquiar verificado nas áreas 1,2 e 4 , merece aqui uma ob servação. Whitten (1966) classifica essa feição como folia ção paralela à estratificação e corresponde à clivagem de acamamento de alguns autores. Ela foi primeiramente verifi cada por R.A. Daly na segunda década do século, na região de Shuswap (Colúmbia Britânica, Canadá) e ele atribuiu sua ori gem a metamorfismo de carga. Observações análogas em ou tras regiões foram feitas por vários autores e a idéia de metamorfismo de carga prevaleceu até meados do século, quando em 1958 A.G. Jones (in Whitten, 1966), através de mapeamento detalhado, mostrou que as observações de Daly se referiam a flancos ondulados de dobras isoclinais recumbentes e que a xistosidade é na realidade do tipo plano-axial. De lá para cá vários estudos verificaram situações análogas em outras regiões.

Hoje aceita-se que a xistosidade pode se desenvolver por ação de carga somente em situações particulares, como no caso de desenvolvimento de texturas belteropóricas ou de do bramento flexural envolvendo delgadas intercalações incompe tentes entre camadas competentes (Whitten, 1966). De resto, 
Fig. 20 - PLANOS AXIAIS E EIXOS DE DOBRAS DA ÁREA I

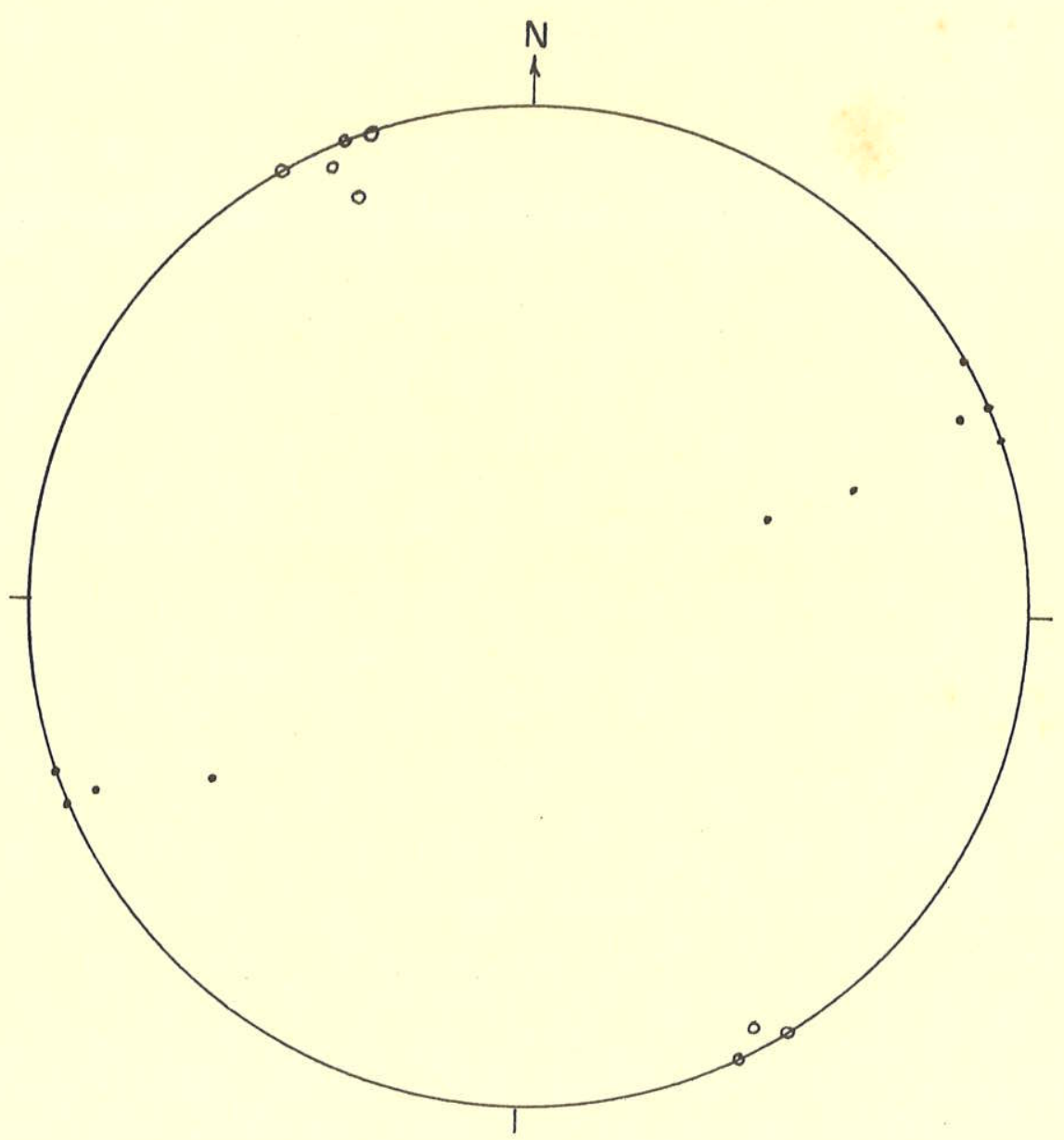

- Eixos de dobras

- Planos axiais 
Fig. 2I-PLANOS AXIAIS E EIXOS DE DOBRAS DA ÁREA 2

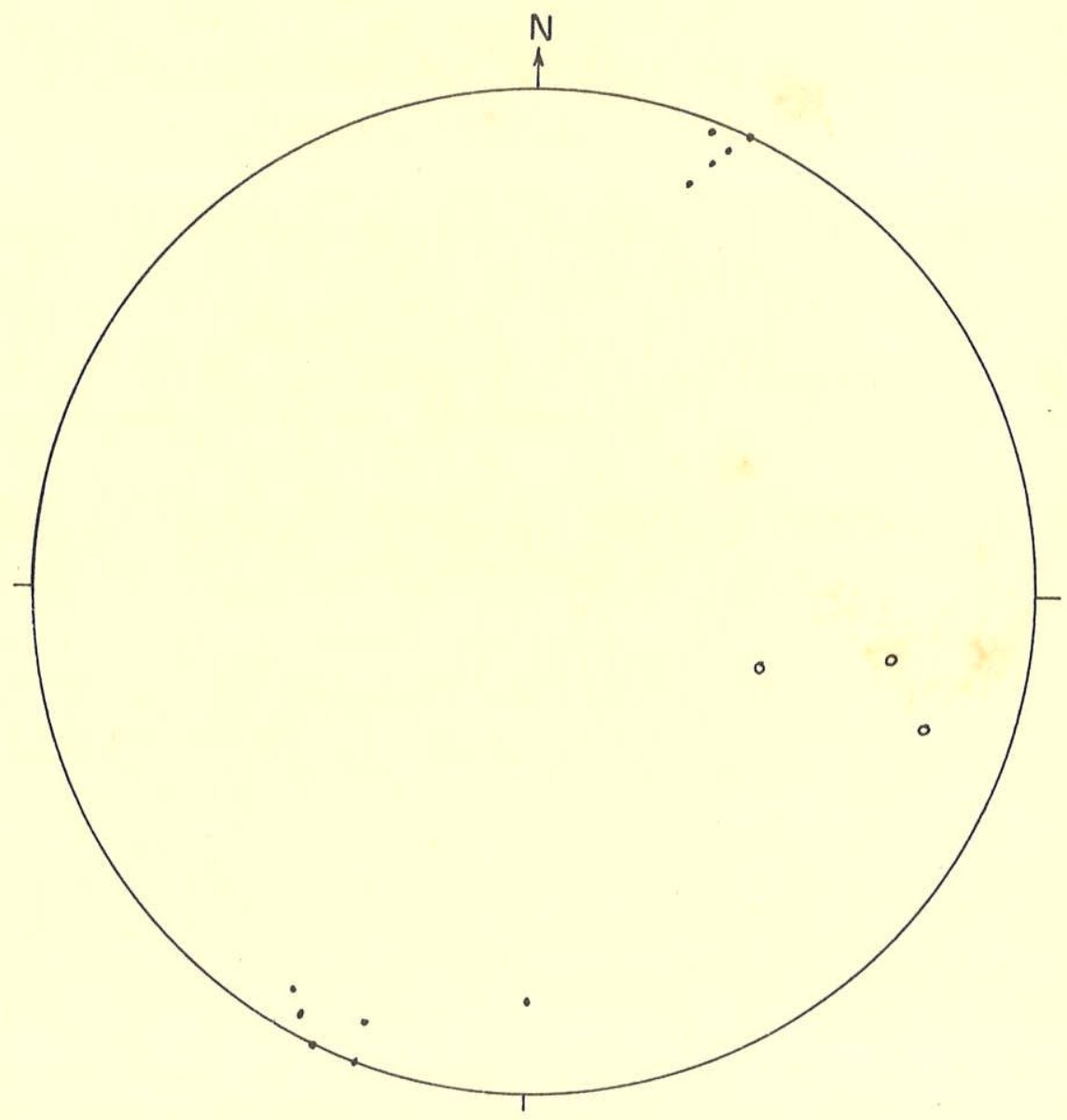

- Eixos de dobras

- Planos axiais 
Fig. 22 - PLANOS AXIAIS, EIXOS DE DOBRAS E LINEAÇÕES b DA ÁREA 3

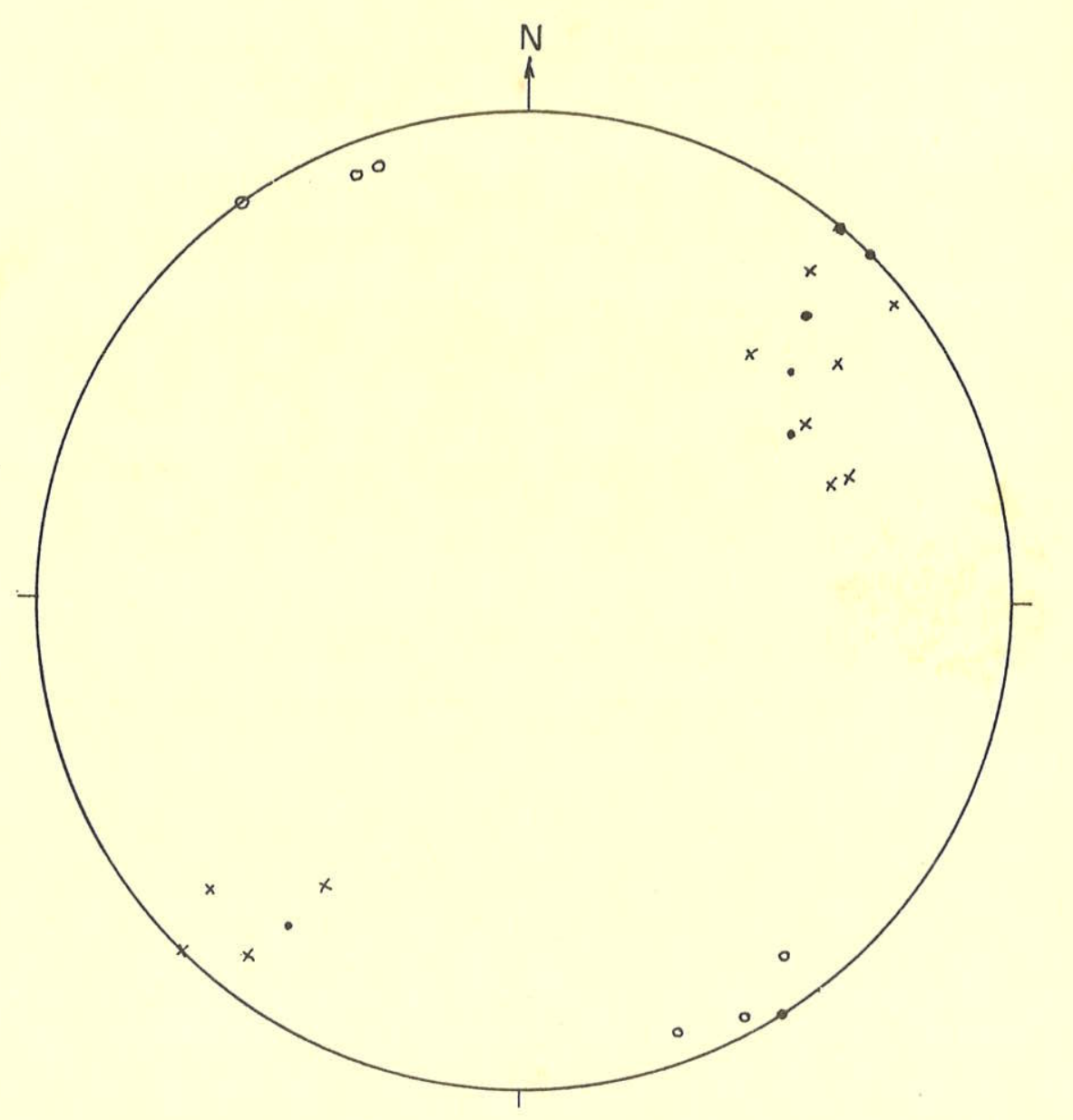

- Eixos de dobras

$x$ Lineaçőes $b$

- Planos axiais 
Fig. 23 - PLANOS AXIAIS E EIXOS DE DOBRAS DA ÁREA 4

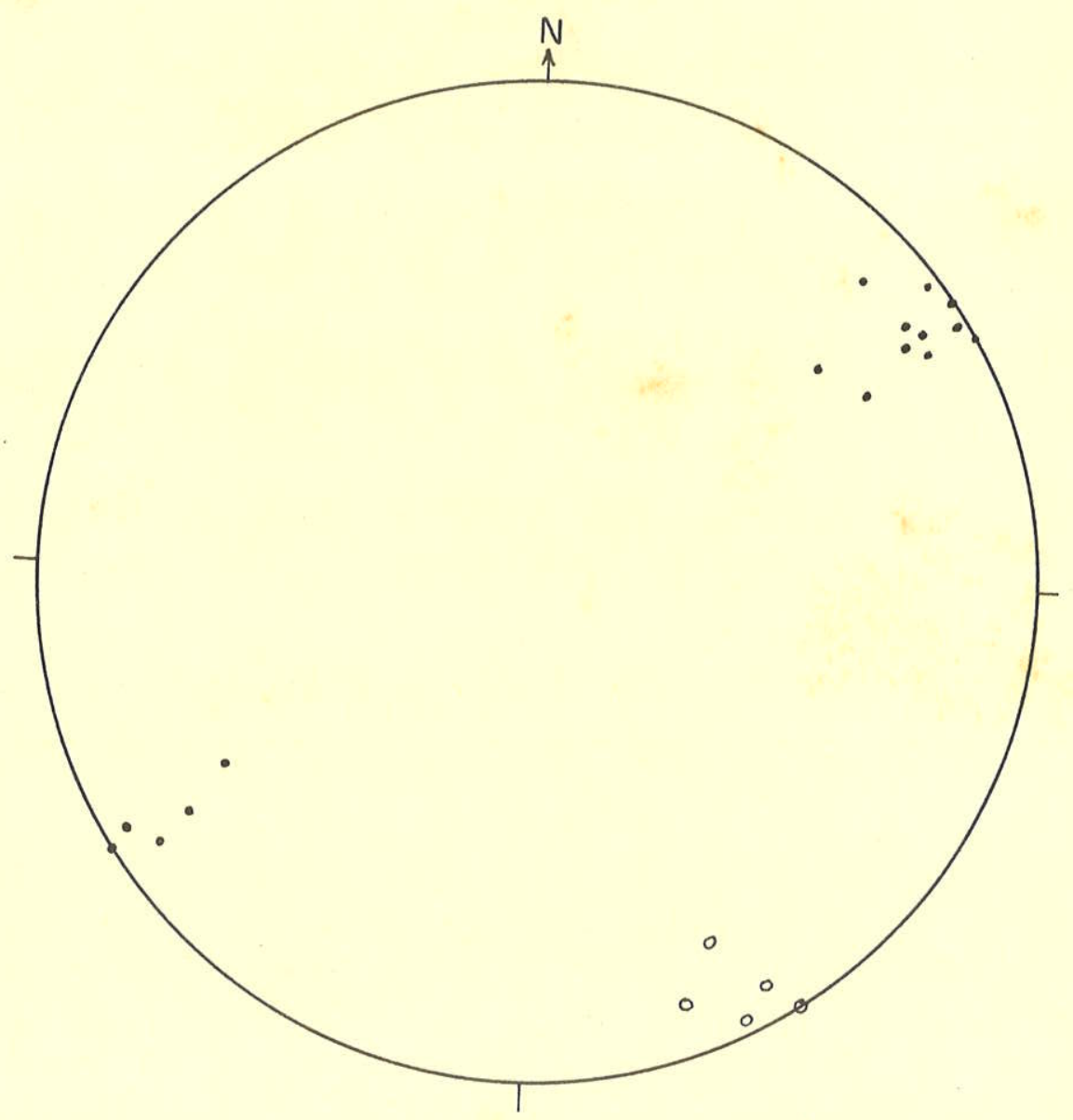

- Eixos de dobras

- Planos axiais 
porém, a concordância xistosidade/estratificação é produzida por redobramentos.

\section{FOLIAÇÃO DE CRENULAÇÃO}

A foliação de crenulação refere-se a sistemas de pla nos de cisalhamento, com espaçamentos microscópicos a milimë tricos, que afetam a rocha (Whitten, 1966). Sua presença é facilmente constatada pelas deformações que acarreta na $x i s$ tosidade. Corresponde à clivagem de deslisamento (Bizlings, 1954), clivagem de cisalhamento (Mead, 1940), clivagem ca taclástica (Knopf, 1931) e clivagem de transposição (Weiss, 1949).

A evolução dessa foliação foi bem esquematizada por Hoeppener (in Sitter, 1964), conforme se vê na Figura 24. Diferentes estágios dessa evolução são observados na área aqui focalizada; três são mostrados nas fotomicrografias 24 e 25.

Manifestam-se em metapelitos dos quatro blocos, ge rando microcorrugações até dobras de amplitude e comprimento de onda decimétricos, com os planos de cisalhamento ocupando posição plano axial (Fotos 10 e ll). As transposições da xistosidade ocasionalmente avançam além das situações mostra das na Figura 24, chegando até a se completar, como mostra a Fotomicrografia 26. Resulta então uma nova xistosidade dis crepante da regional (Whitten, 1966). Essa transposição não foi acompanhada de recristalização.

Frequentemente, a foliação é tão bem desenvolvida que a fissilidade da rocha se manifesta preferencialmente atra vés dela em vez de incidir ao longo da xistosidade ou da és tratificação.

A transposição se deu posteriormente à formação dos porfiroblastos da moscovita, pois estes mostram deformações, 
Fig. 24- DESENVOLVIMENTO DA FOLIAÇÃO DE CRENULAÇĀO

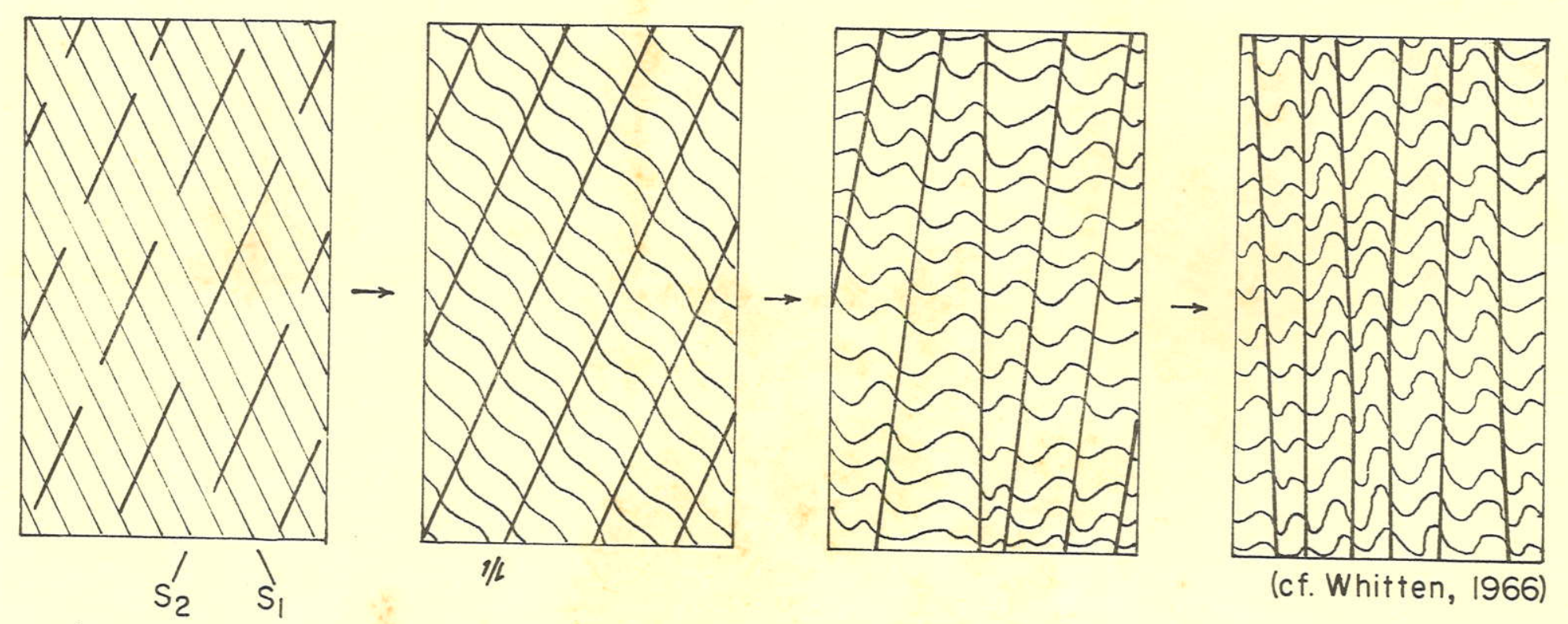




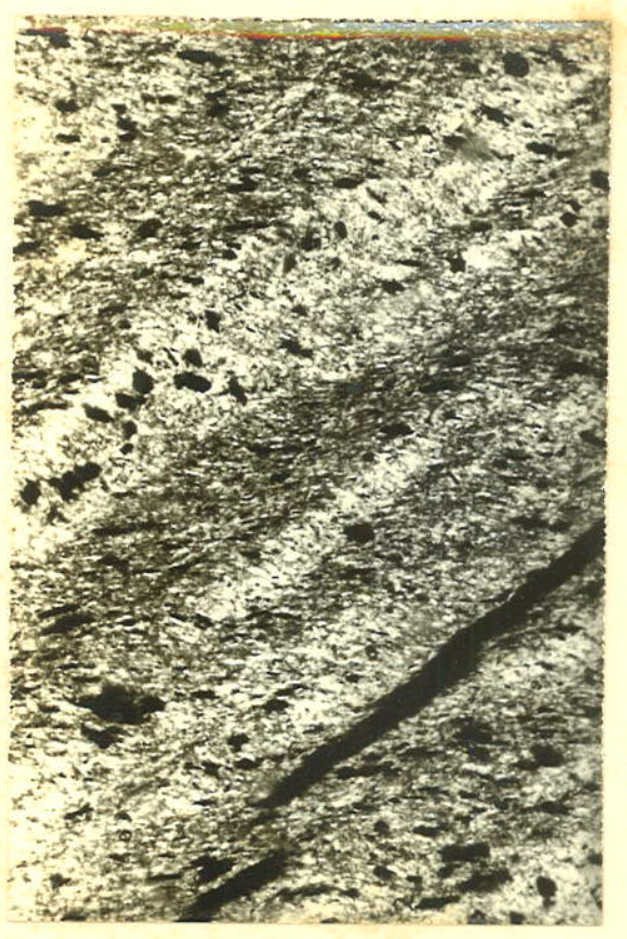

FOTOMICROGRAFIA 24 - Filito com foliação de crenulação incipiente. Notam-se faixas e cristais de pirita cristalizados a

longo dos cisalhamentos e da xistosidade.

$480 \times \mathrm{N}^{+}$. Amostra 223, 6 km SE de Pilar do Sul.

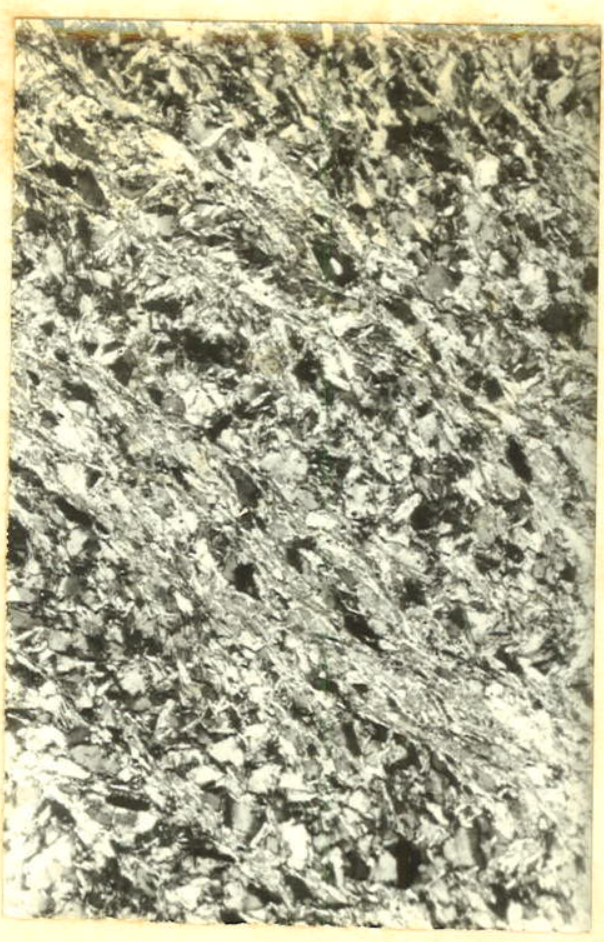

FOTOMICROGRAFIA 25 - Filito com foliação de crenulação mais desenvolvida. A transposição se completou ao longo de faixas (planos de cisalhamento). gerando uma nova xistosi dade.

192X N+.Amostra 152, 15 $\mathrm{km}$ SSE de São Miguel Ar$\operatorname{canjo.}$

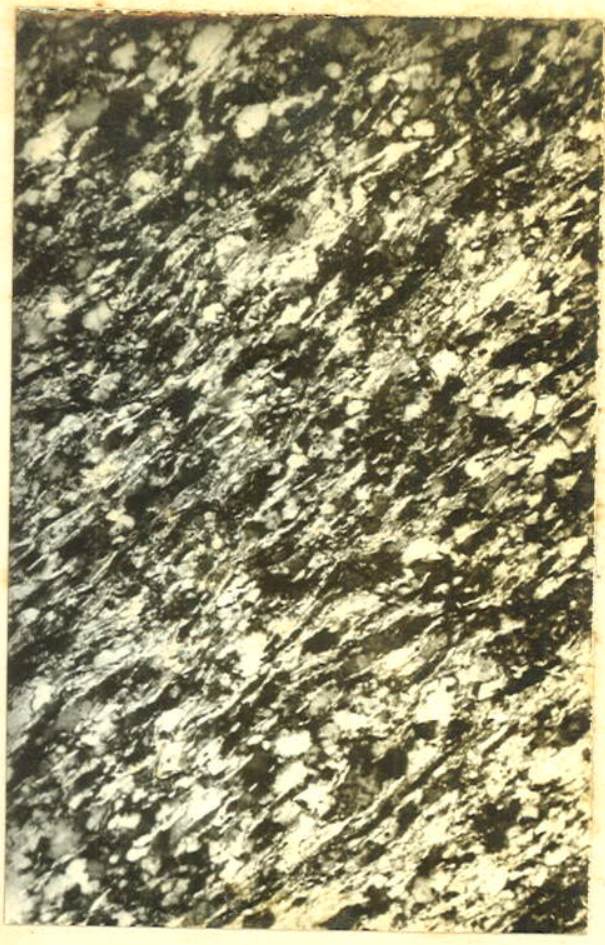

FOTOMICROGRAFIA 26 - Filito com foliação de crenulação, bem evoluida. transposição foi total. $480 \times \mathrm{N}+$. Amostra 150, 15 $\mathrm{km}$ SSE de São Miguel Arcanjo. 


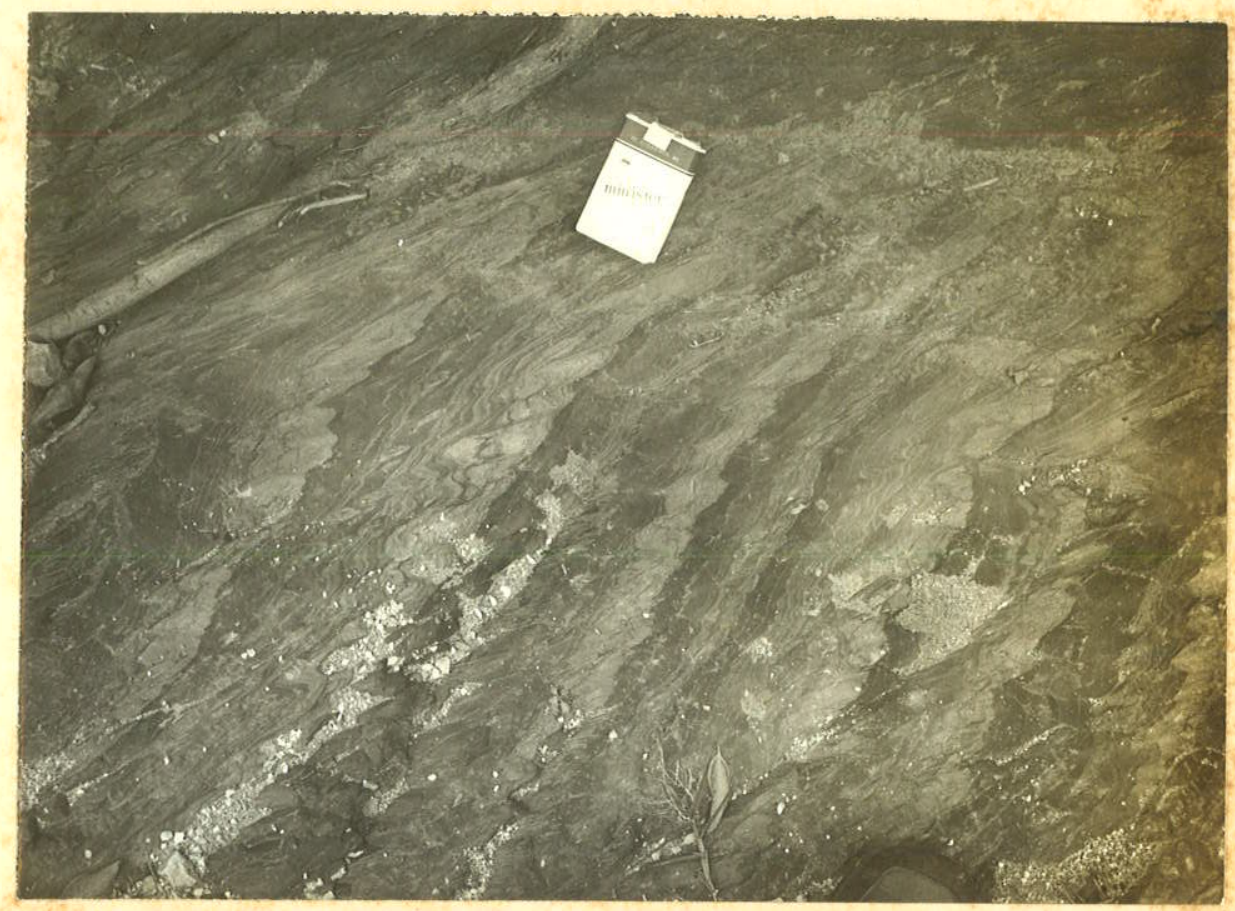

FOTo 10 - Foliação de crenulação $\left(S_{2}\right)$ em metapelitos rftmicos. Rodovia Raposo Tavares, $\mathrm{km} 80$, a $6 \mathrm{~km}$ de Bri gadeiro Tobias para Alumínio. 


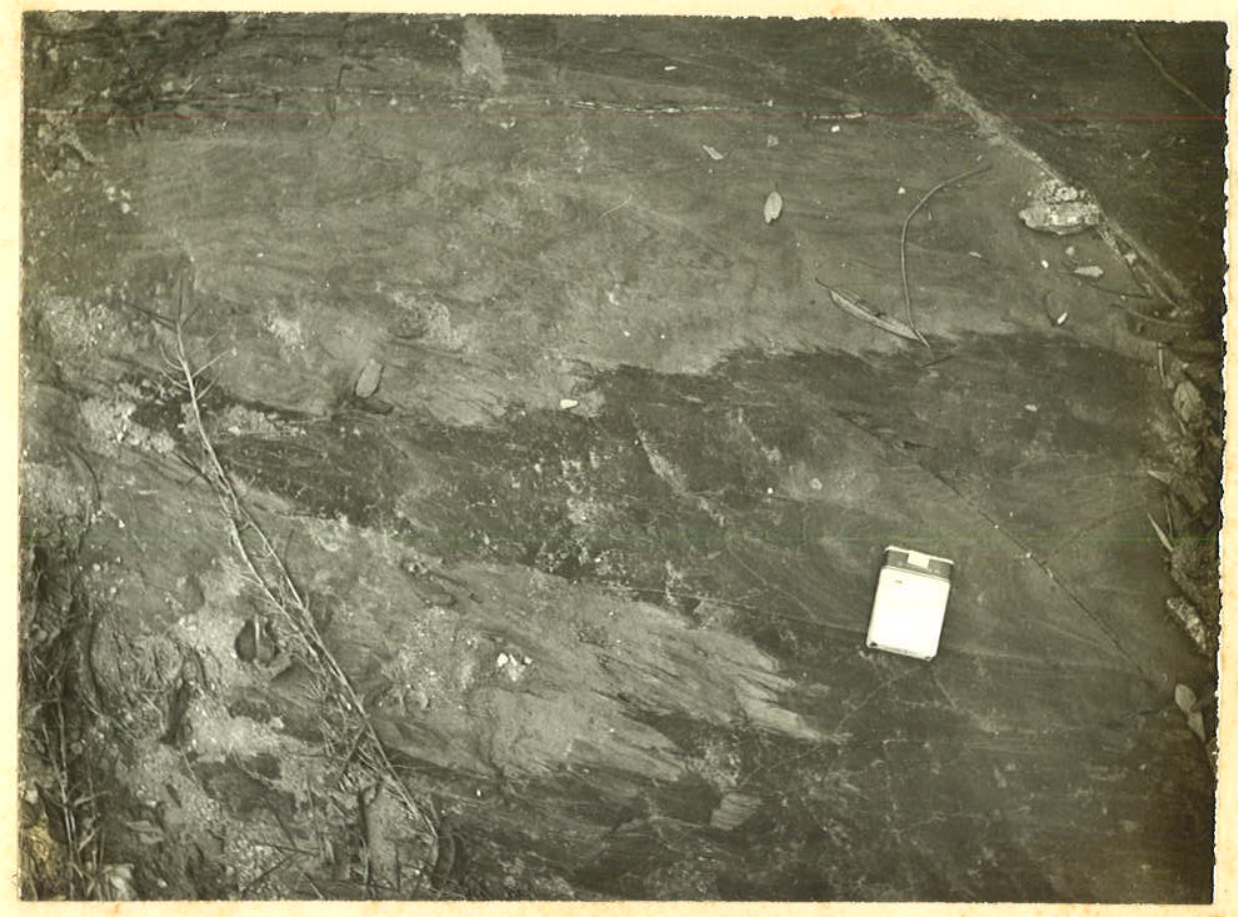

FOTO 11 - Foliação de crenulação em metapelitos rítmicos. Os pequenos anticlinórios e sinclinórios resultam da transposição. Rodovia Raposo Tavares, km 80, a $6 \mathrm{~km}$ de Brigadeiro Tobias para Alumínio. 
como se vê nas Fotomicrografias 27 e 28 . Na Fotomicrografia 29 a transposição incidiu num conjunto de porfiroblastos e eles estão praticamente alinhados segundo os planos de cisa Ihamento, obviamente configurando uma nova xistosidade à ro cha. Observa-se que os porfiroblastos não são truncados, mas simplesmente são levados a sofrer rotações; os planos de cí salhamento inclusive sofrem desvios de modo a contorná-los.

Nesta oportunidade, não procuramos definir a folia ção de crenulação em termos quantitativos: limitamo-nos a observar sua presença e seus efeitos. Todavia, não são ob servados sistemas conjugados de planos de transposição e o sistema presente parece ser paralelo ao sistema NW de juntas (de cisalhamento, como veremos).

\section{LINEAÇÕES}

Vários tipos de lineações são observados na área es tudada. Já nos referimos às lineações desenvolvidas nas zonas de falhamento, pela moínha de minerais triturados.

Outro tipo de lineação é dado pela interseção de es truturas planares. O caso mais importante é o da xistosida de plano-axial e o acamamento reliquiar, cuja interseção dá uma linha (lineação b) paralela ao eixo da dobra (lineação B). Outras feições planares (juntas, foliação de transposição, etc.) também se intersectam segundo linhas, mas essas não fo ram objeto de medições no campo.

Cabe destacar que a fissilidade das rochas pode ser dada pelo acamamento reliquiar, pela xistosidade e pela fo liação de crenulação. Na superfície de disjunção, as linea ções correspondentes a interseções são sempre bem visiveis.

Um outro tipo de lineação é desenvolvido por mine rais prismáticos. É o que se observa nos anfibolitos,com os prismas de hornblenda em textura nematoblástica, desenvolven do uma lineação b. 


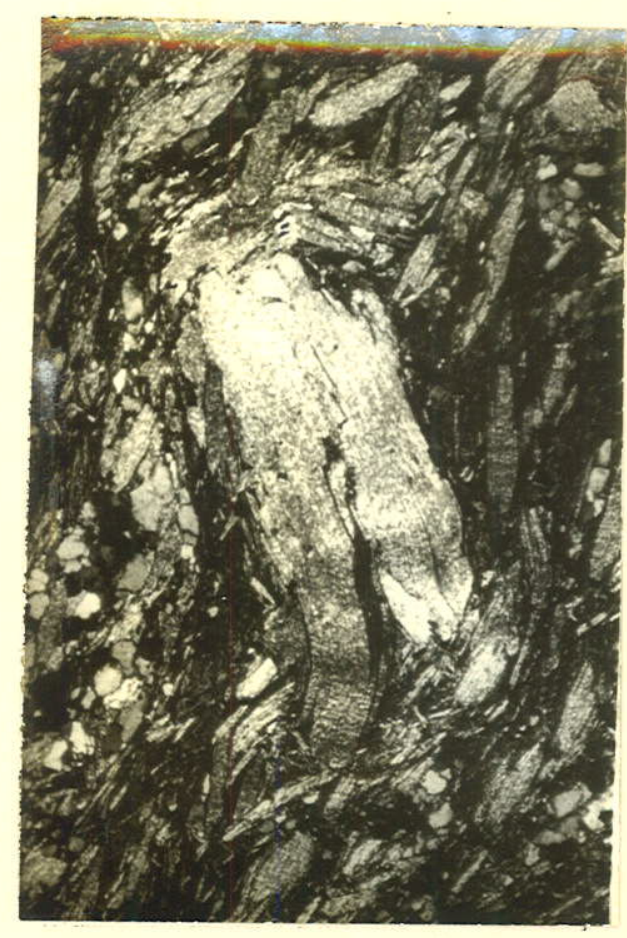

FOTOMICROGRAFIA 27 - POrfiro blasto de moscovita dis= cordante com a xistosida de do micaxisto, sofren do rotação devida transposição.

192X N+.Amostra 177, 15 km SSE de Ibiúna.

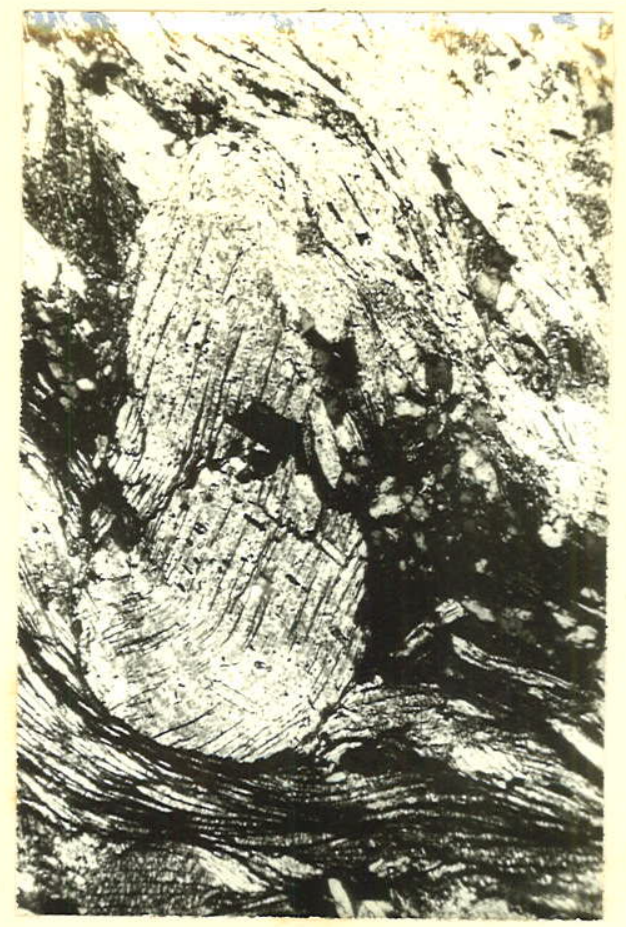

FOTOMICROGRAFIA 28 - POIfirO blasto de moscovita discordante da xistosidade, sofrendo rotação devida a transposição. Os planos de cisalhamento se encurvam (traços escuros na parte inferior da foto).

192X N+.Amostra 318 , entrada de Juquitiba pela $B R-116$.

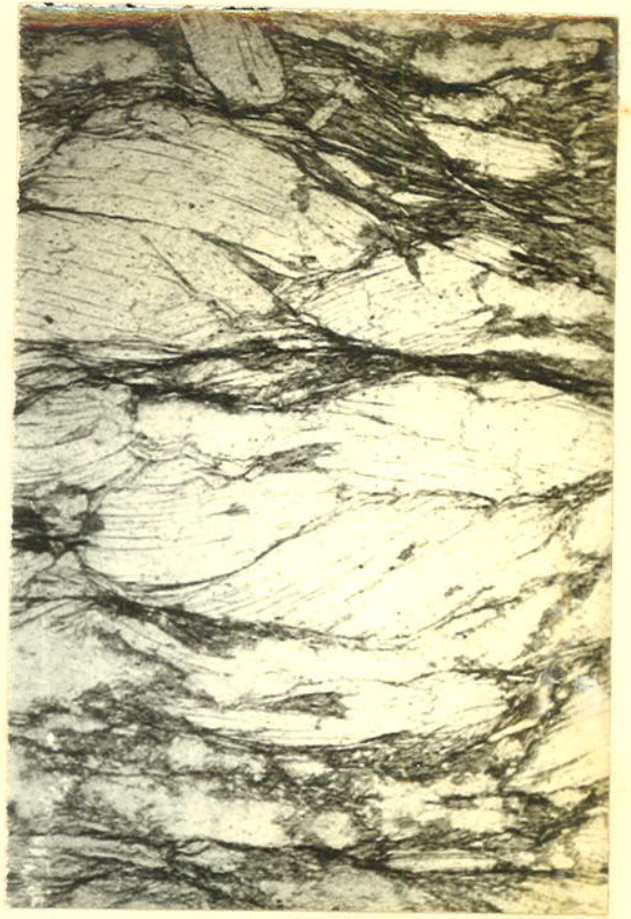

FOTOMICROGRAFIA 29 - POIfiro blastos de moscovita transpostos totalmente ou quase totalmente. Os planos de cisalhamento são subhorizontais na fo to.

192X N+.Amostra 175, 15 $\mathrm{km}$ SSE de Ibiüna. 
Por fim, temos as lineações correspondentes a elemen tos geométricos de estruturas. Eixos de dobras (lineação B), eixos de crenulações, eixos de dobras de arrasto (lineação b) e eixos de boudins (lineação b) de quartzito e quartzitos calco-silicáticos, são observados com frequência.

Nos diagramas das Figuras 20, 21 e 23, as Jineações representadas são as de tipos $B$, enquanto na Figura 22 foram lançados b e $B$.

\section{DOBRAS}

As dobras observadas na área são cilassificáveis

em duas categorias (Donath e Parker, 1964):

1 - dobras de flexão, em que as camadas se deslocam umas em relação às outras através dos planos de estratificação;

2 - dobras de cisalhamento, em que as camadas são deslocadas por transposições ao longo de sistema de planos paralelos.

o primeiro tipo é, de longe, o mais importante. Elas têm dimensões variáveis desde microscópicas até decaquilométricas, escalonáveis em várias ordens.

As dobras maiores (ordem $n$ ) são antiformas, em cujo núcleo se introduziram alguns corpos granitóides sintectóni cos ou se vêm rochas metamórficas mais transformadas ( migma titos oftalmíticos), e as sinformas entre essas culminações.

A relação entre as antiformas maiores e os corpos sin tectónicos é reconhecida de maneira clara pelos seguintes fa tos:

1 - presença de faixas de rochas de metamorfismo re gional de graus cada vez mais elevados à medida que se apró xima da intrusão. Tal se constata em relação aos corpos de São Francisco e Sorocaba. No Bloco Juquitiba esse fato não 
se verifica, pois as encaixantes são rochas desenvolvidas em fácies anfibolito;

2 - litologias típicas, como da sequência carbonáti ca, presentes de um e outro lado da intrusão alongada, bem como sob forma de tetos pendentes ou xenólitos no corpo in trusivo. Esse fato se observa no Maciço de São Francisco e São Roque.

Quanto aos núcleos de migmatitos oftalmíticos, eles traduzem uma metassomatose mais acentuada, como se mostrou em capítulo anterior. Isso pode ser vinculado a núcleos de cul minações estruturais.

Dessa maneira, na ärea estudada podemos associar o Maciço de São Francisco e o de Sorocaba bem como as faixas de migmatitos oftalmíticos, a grandes estruturas culminantes orientadas segundo o alongamento dos corpos.

Os Maciços de São Roque e de Piedade têm limites, na maior parte, por falhas, de sorte que é difícil inferir o seu alongamento original. No caso do Maciço de São Roque, o mapa apresentado por Hasui et al. (1969) mostra que a borda leste descreve um arco com a convexidade voltada para oeste.

Três faixas de migmatitos oftalmíticos terminam no canto sudeste da Folha de São Roque e a elas podemos asso ciar estruturas culminantes.

Quanto aos demais corpos intrusivos do Bloco Juquiti ba, somente observamos as formas alongadas segundo a orienta ção geral dos dobramentos. Nenhuma outra feição se soma pá ra lhes associar estruturas antiformais.

Uma outra estrutura de grande porte é dada pela enor me faixa de migmatitos estromatíticos embutida no Complexo Piedade, na região de Ibiuna-Aguaçai-Serra de São Sebastião. Ao longo da faixa, as atitudes indicam uma conformação anti clinorial, com eixo geral segundo N45E mergulhando para NE. A zona apical mostra ondulações menores, que são antiformas e sinformas de menor ordem (ordem $n+1)$, e se acham repre 
sentadas na Folha de São Roque anexa. Trata-se de um anti clinório desventrado.

No Bioco Ituparanga, as intrusões das Lavras e de Pirapora também são relacionáveis a uma megaestrutura anti formal.

Estruturas sinclinoriais são constituídas pelas fai xas que separam os Maciços São Francisco/Sorocaba e São Roque/ IItaqui. Também na região de Pilar do Sul, conformando-se à borda do Maciço de Piedade, os metamorfitos se fletiram em enorme estrutura sinclinorial. No Bloco Juquitiba, entre as faixas de migmatitos oftalmíticos existem zonas de migmatitos estromatiticos, com quantidades de neossoma variando de ma neira a indicar áreas intermediárias menos afetadas, o que nos permite inferir a existência de estruturas sinclinoriais.

Essas estruturas de ordem $n$ acham-se indicadas na $F_{\underline{i}}$ gura 25.

As dobras decamétricas a hectométricas que se reco nhecem em afloramentos são de ordem $n+1$. Elas simplesmente complicam os flancos das estruturas maiores.

Por sua vez, vemos com frequência em afloramentos, em amostras e ao microscópio ondulações menores (ordem n + 2) complicando os flancos das dobras de ordem $(n+1)$.

Todas as dobras, mesmo em camadas competentes, têm aberturas de baixo ângulo, sendo qualificáveis às vezes como fechadas $\left(30^{\circ}-50^{\circ}\right.$ de abertura dos flancos) ou isoclinais (flan cos paralelos), mas via de regra são cerradas, com $0^{\circ}-30^{\circ}$ de abertura (Fotos 12 a 17 e Fotomicrografias 30 e 31 ). A am plitude é bem maior que o comprimento de onda, tendo-se en tão flancos extensos e zonas apicais restritas. Por isso,em afloramentos é normal encontrarmos porções de flancos, com atitudes quase constantes (Foto 6), e apenas raramente ápices. As ondulações observáveis são no geral ligeiramente assimétricas, e mais raramente apresentam perfeita simetria 
Fig. 25 - DOBRAS MAIORES NA ÁREA ESTUDADA

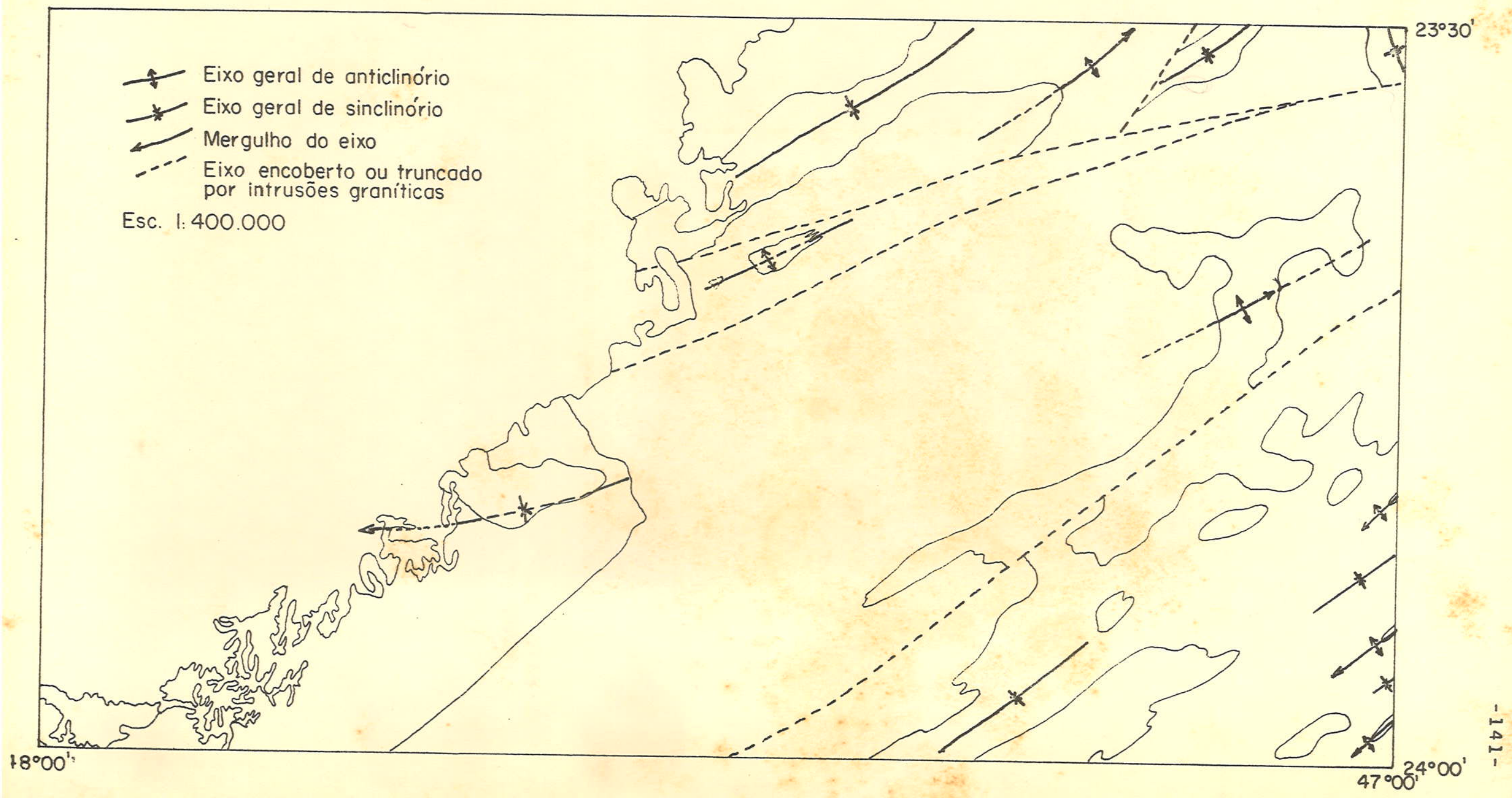




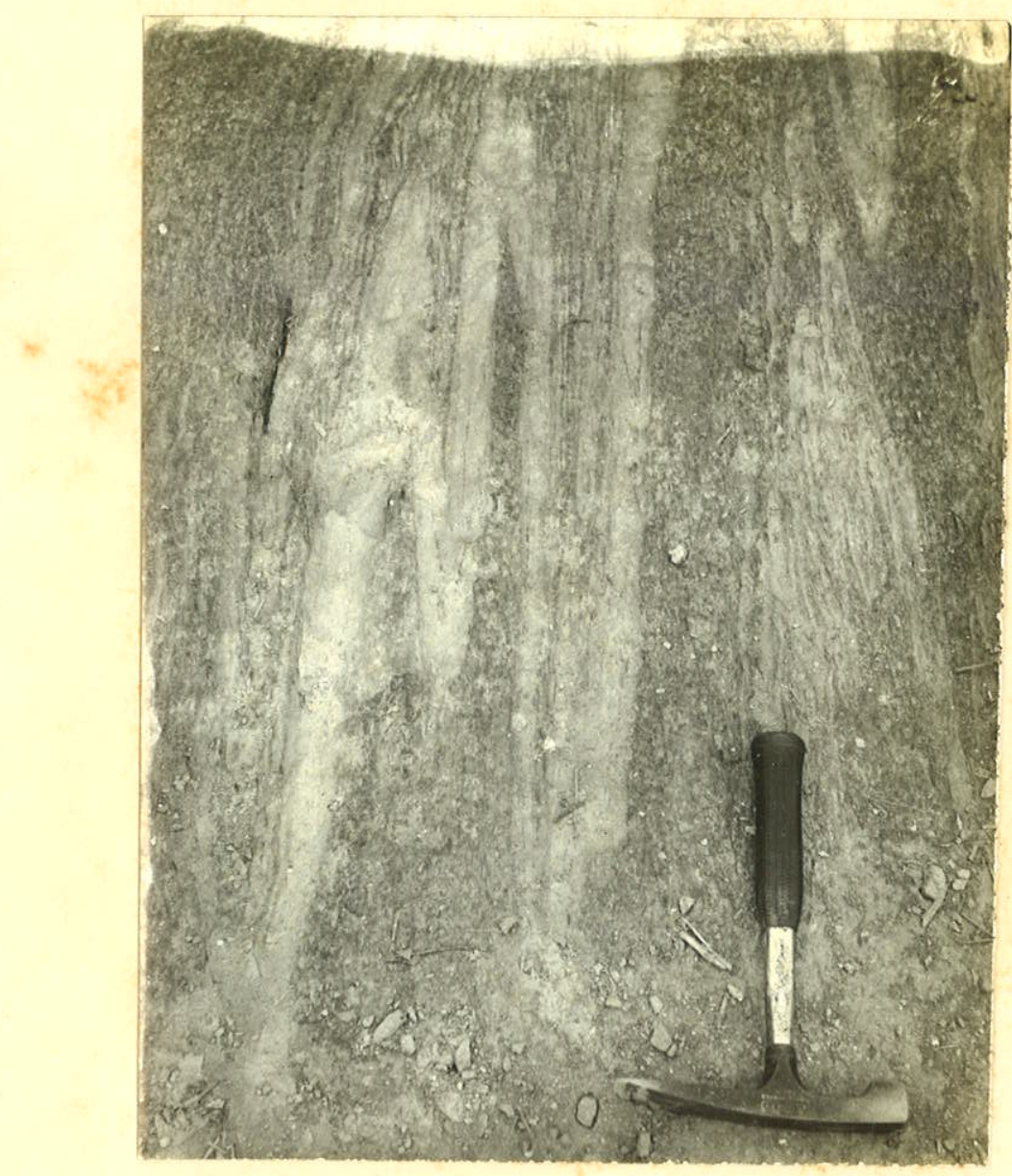

FOTO 12 - Dobras cerradas em leitos de quartzito intercalados em filito rítmico. Bairro do Leite, Município de Piedade. 


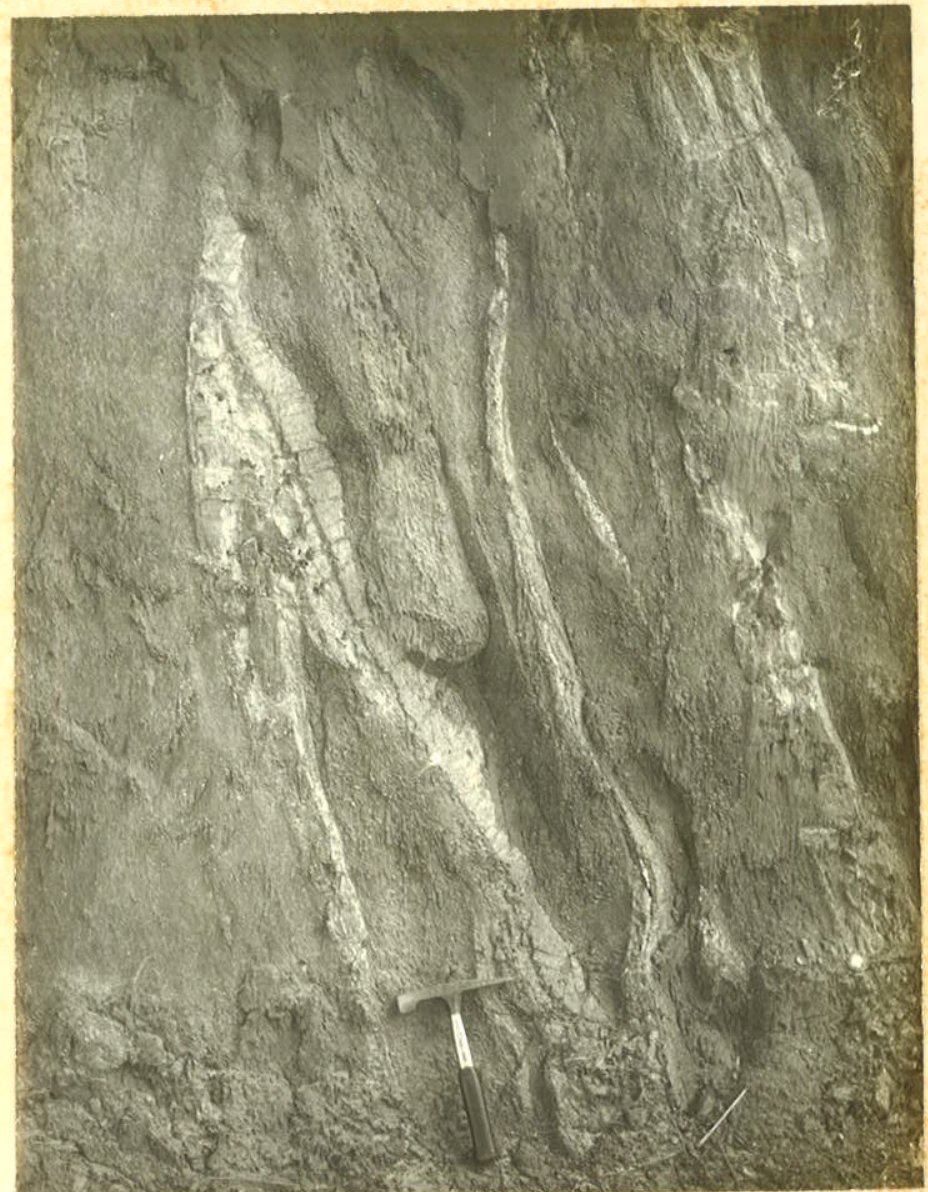

FOTO 13 - Dobras cerradas em lente de quartzito intercalada em migmatitos estromatíticos. A direita houve transposição isolando segmentos da lente. Nordeste de Juquitiba, no vale do Ribeirão do Godinho. 


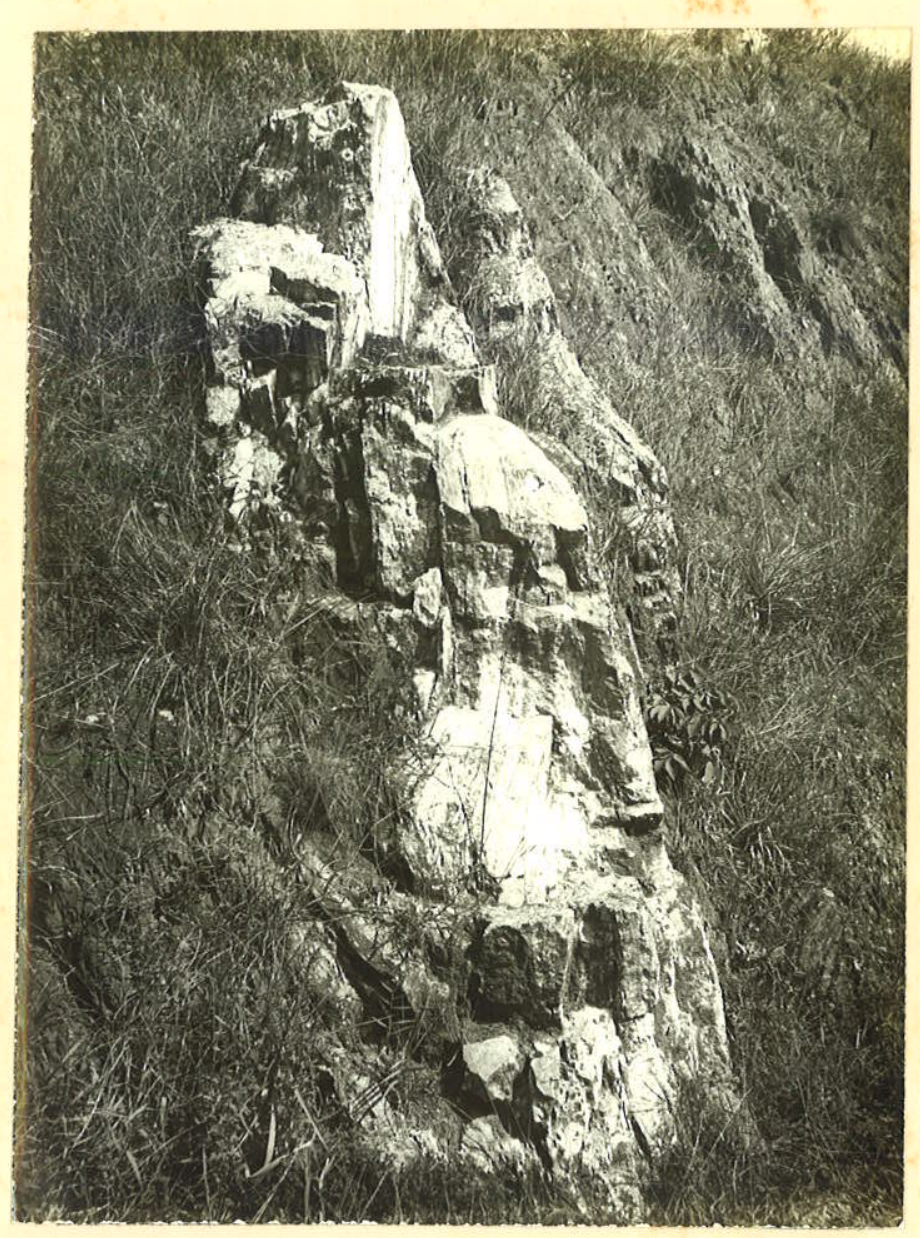
FOTO 14 - Dobra cerrada em rocha calcosilicatada. Rodovia Raposo Tavares, saída de São Ro- que para Mairinque.




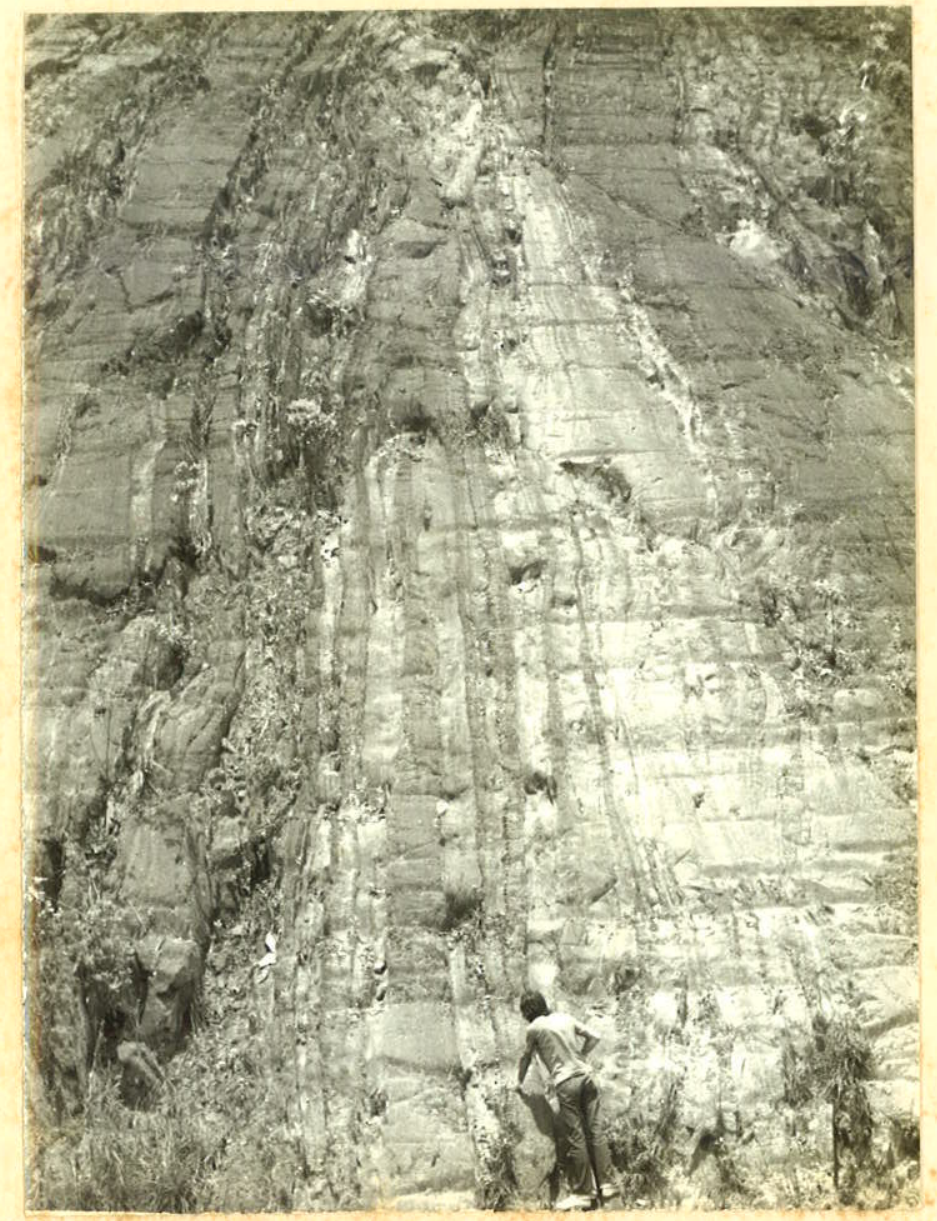

FOTO 15 - Anticlinal isoclinal nos migmatitos es tromatíticos, configurada pela xistosi dade e pelo bandeamento. Corte na BR116, à entrada de Juquitiba. 


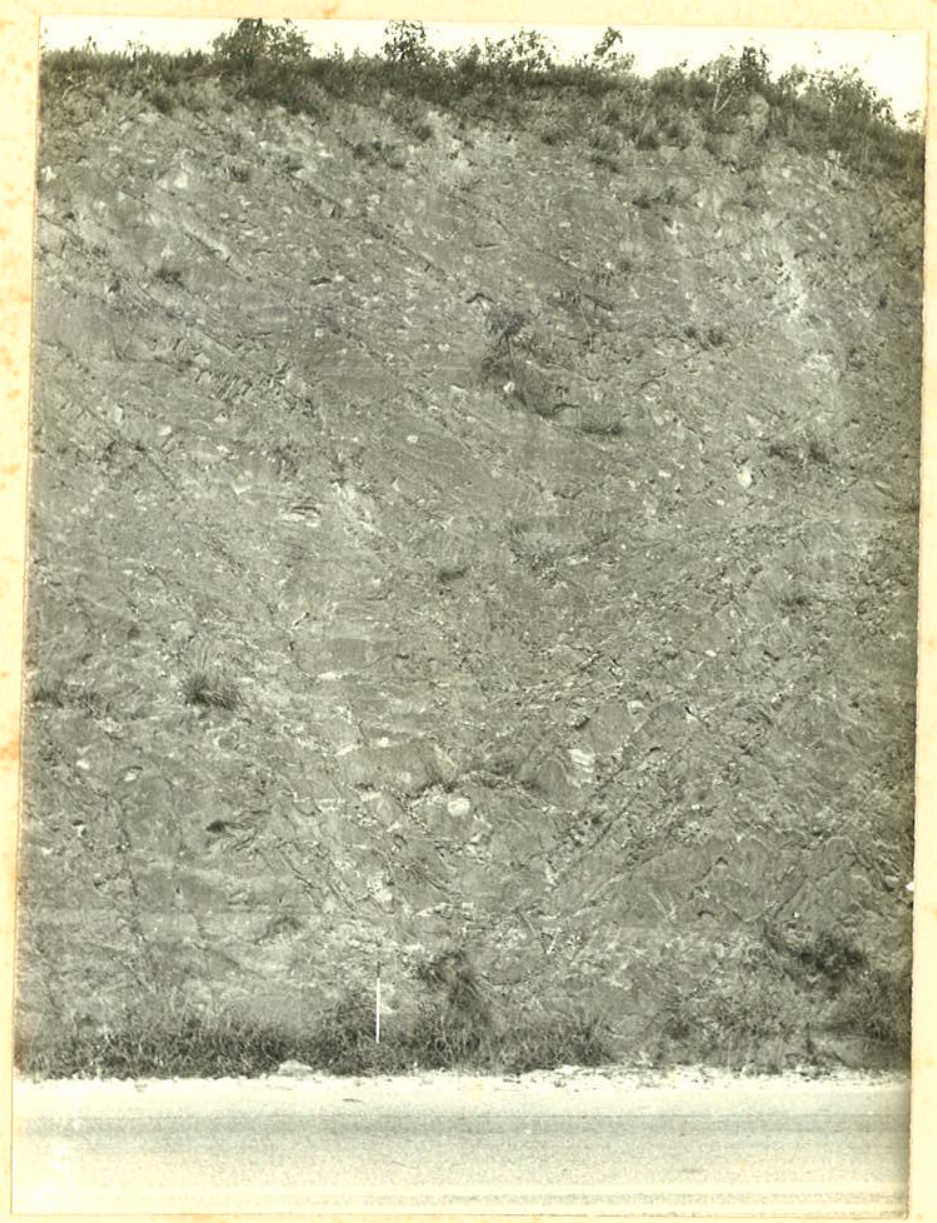

FOTO 16 - Dobra fechada em ritmito (camadas cons pícuas de quartzito e camadas discretas de xisto alternadas). Rodovia Rapo so Tavares. $\mathrm{Km} 83$, a $3 \mathrm{~km}$ de Brigadei= ro Tobias para Alumínio. 

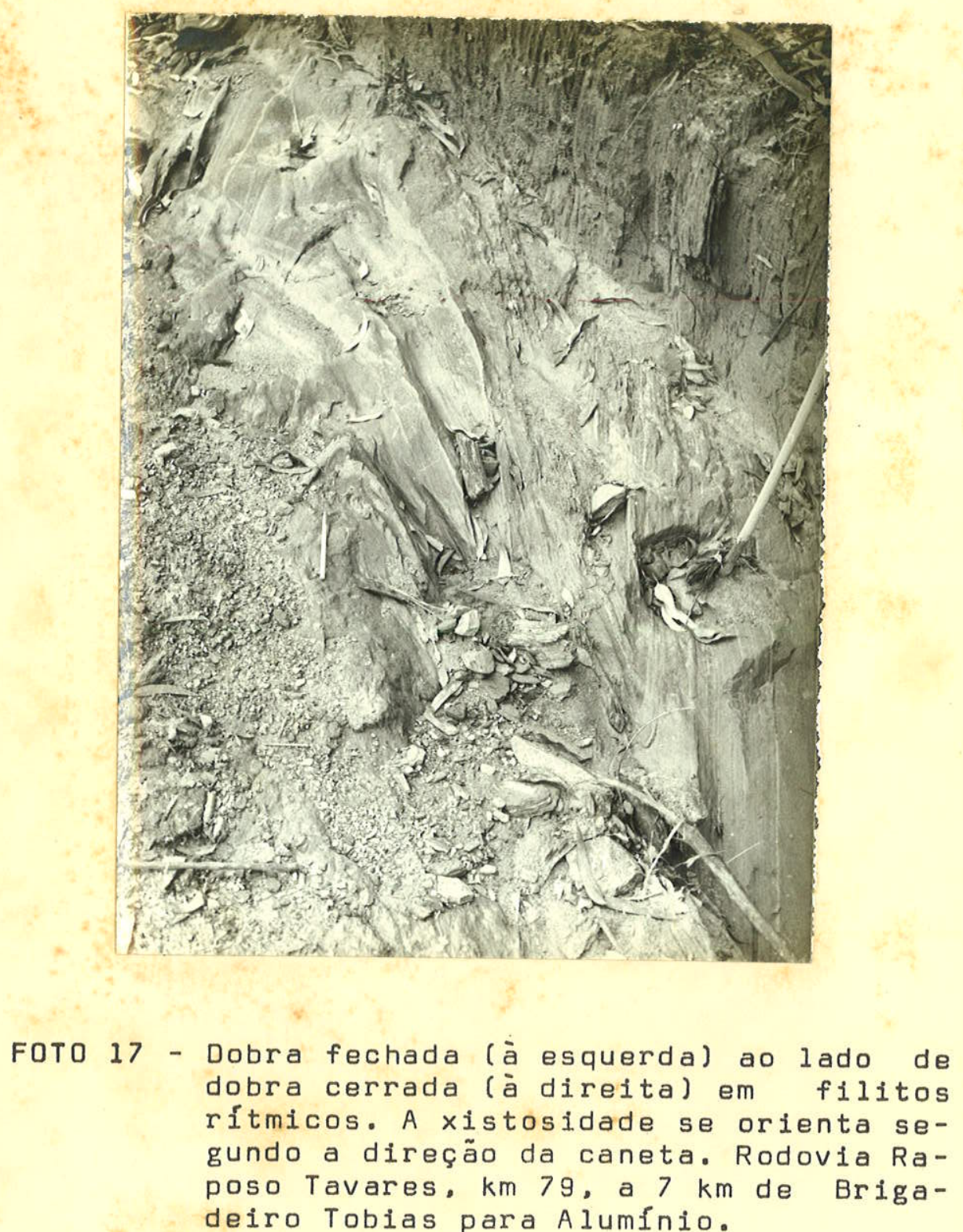

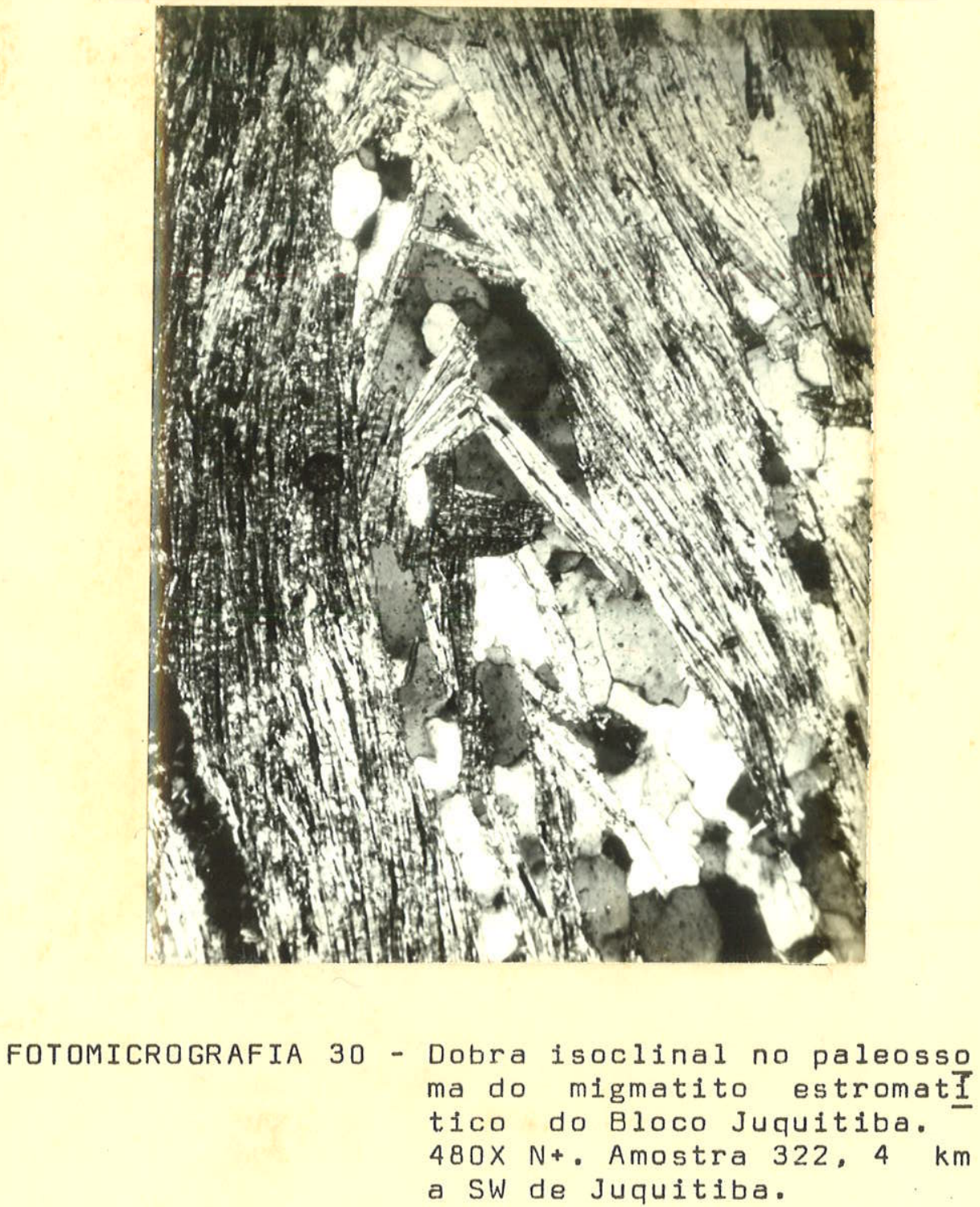


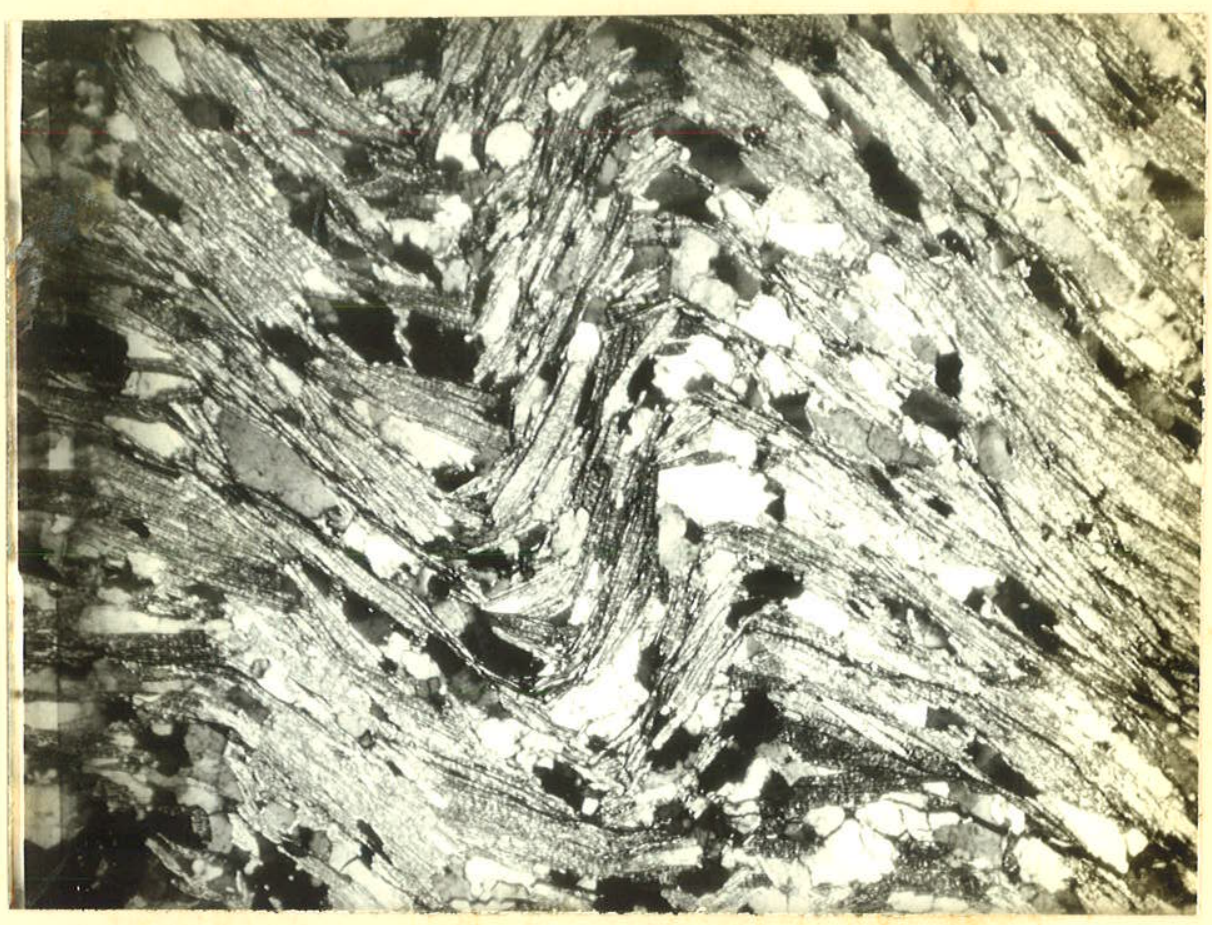

FOTOMICROGRAFIA 31

- Dobras fechadas em micaxisto. A

esse dobramento parece rejacionar-se a rota ção da granada da Fotomicrografia 34. 192X N+. Amostra 234, $7 \mathrm{~km}$ a ENE de Pi lar do Sul. 
ou assimetria mais acentuada.

O diagrama de acamamento na área 3 (Figura 17) mos tra que as dobras são cilindricas (Whitten, 1966), com flan cos de mergulhos dominantemente subverticais. A xistosidade aí (Figura 18) também tem mergulhos subverticais. Ela é do tipo plano-axial, mas dada a semelhança de suas atitudes com as da estratificação, vêmo-las paralelas nos afloramentos ou discordantes segundo pequenos ângulos. Só nos ápices das do bras e suas proximidades é que a discordancia se dá em ângu los elevados (Fotos 9 e 17).

Os diagramas da Figuras 15, 16 e 19 indicam que do bras de formas idênticas estão presentes, configuradas pela xistosidade e pelo acamamento. Não observamos nenhum caso de discordâncias entre essas estruturas planares. A Fotomi crografia 32 mostra o ápice de uma dobra, mostrando a flexão de placas de moscovita.

- caráter cilíndrico do dobramento não é perfeito,já que os polos não caem num mesmo circulo máximo, mas apresen tam certo grau de dispersão. Isso se deve ao fato de as áreas consideradas não serem rigorosamente homogêneas. Tal fato, porém, não prejudica as conclusões (Whitten, 1966).

A orientação dos eixos de dobras, observados ou infe ridos através de lineações b, são mostrados nas figuras 20 a 23. Eles coincidem aproximadamente com os eixos médios das guirlandas. São horizontais e subhorizontais, com direções mais ou menos constantes, isto é, os dobramentos são homo axiais em cada área analisada.

Quanto aos planos axiais, vemos pelas figuras 20 a 23, que eles coincidem na maior parte com as atitudes dominan tes da xistosidade.

Na área 1 predominam atitudes de xistosidade e acama mento com mergulhos subverticais voltados para SSE, o que tra duz uma assimetria das dobras nesse sentido. Por sua vez 


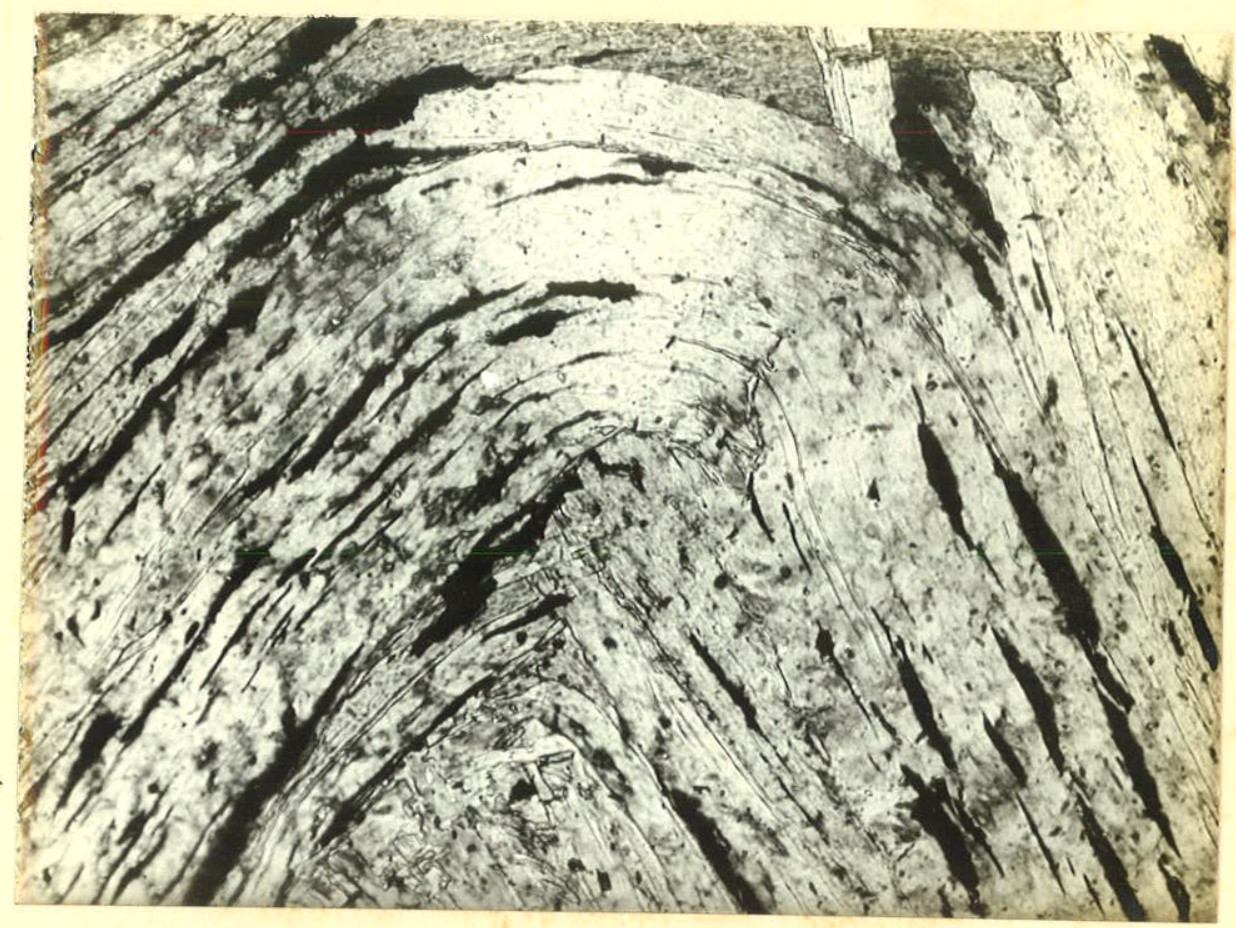

FOTOMICROGRAfiA 32 - Apice de dobra cerrada, mostrando placas de moscovita arqueada no paleosso ma de migmatito estromatítico do Bloco Juquitiba.

$1200 \times \mathrm{N}+$. Amostra 321, $11 \mathrm{~km}$ a SW de Juquitiba. 
na área 2, o sentido correspondente é WNW. Nas äreas 3 e 4 , o rumo é NNW.

Nota-se que o sentido da vergência nas áreas 2,3 e 4 se volta pára o quadrante SE, enquanto na área 1 , dá-se o contrário, voltando-se para o quadrante NE.

Essas conclusões, porém, devem ser acompanhadas das seguintes ressalvas:

1 - as atitudes predominantes de xistosidade, acama mento e planos axiais de dobras são subverticais, com peque nos desvios. Na falta de exposições contínuas, pode-se con siderar que vícios de amostragem, por menores que sejam, podem modificar os resultados;

2 - as atitudes variam em direção e em sentido, por influência das intrusões granitóides e falhamentos posteriores.

Parece-nos, pois, dificil no momento inferir um sen tido de vergência; diríamos até que ela se mostra indefinida.

No dobramento, as camadas, mesmo as mais competentes (quartzitos, como nas Fotos 12 e 13, rochas calcosilicatadas, como na Foto 14), se comportaram similarmente, com adelgaçamento nos flancos e espessamento nos ápices. Apenas ocasio nalmente se vêm dobras concêntricas em camadas de quartzito; ai as intercalações metapelíticas exibem dobras de arrasto ou parasiticas. Quando se trata de intercalações restritas de quartzito em metapelitos, ambos exibem perfis diferentes de dobras, com o material menos competente mostrando padrões mais complicados de ondulações (dobras desarmônicas).

Quanto às dobras de cisalhamento, geradas pela folia ção de crenulação, são sempre de pequeno porte, microscópicas a centimétricas. 0 processo afeta a xistosidade e a estrati... ficação, introduzindo padrões complexos.

Como já vimos, a transposição pode evoluir até a si tuação de criar nova xistosidade. 
QUALIFICAÇÃO DOS SISTEMAS DE JUNTAS

Examinadas as atitudes dos sistemas de juntas, da xis tosidade, dos planos axiais das dobras e dos eixos das do bras, podemos relacionar as juntas com os dobramentos de fle xão.

Confrontando os diagramas das Figuras 11 a 14 com os das Figuras 15 a 23 infere-se que:

1 - um sistema de juntas subverticais é paralelo à xistosidade na área 3 e ao plano axial das dobras das demais áreas. São juntas longitudinais em relação aos eixos das do bras (Foto 18);

2 - um sistema de juntas subverticais é subperpendicular à xistosidade na área 3 e ao plano axial das dobras nas demais áreas. São juntas transversais em relação aos eixos das dobras;

3 - dois sistemas de juntas subverticais são oblíquos à xistosidade na área 3 e ao plano axial das dobras nas de mais áreas. São juntas diagonais em relação aos eixos das dobras;

4 - um sistema de juntas de baixo ângulo de mergulho está presente em todas as áreas.

Exceto este último sistema que é atribuível a alívio de carga ("sheeting" de Bizlings, 1954), os demais podem ser relacionados com a própria mecânica do dobramento. Os sis temas citados em 1 e 2 são de partição, o primeiro relaciona do com a flexão longitudinal e o segundo a arqueamento dos eixos das dobras.

Os dois sistemas citados em 3 são os de cisalhamento conjugados (Badgley, 1965). Pequenas falhas, de rejeitos mé tricos ou menores, são frequentes e exibem atitudes condizen tes com os sistemas de juntas de cisalhamento. Além disso, 


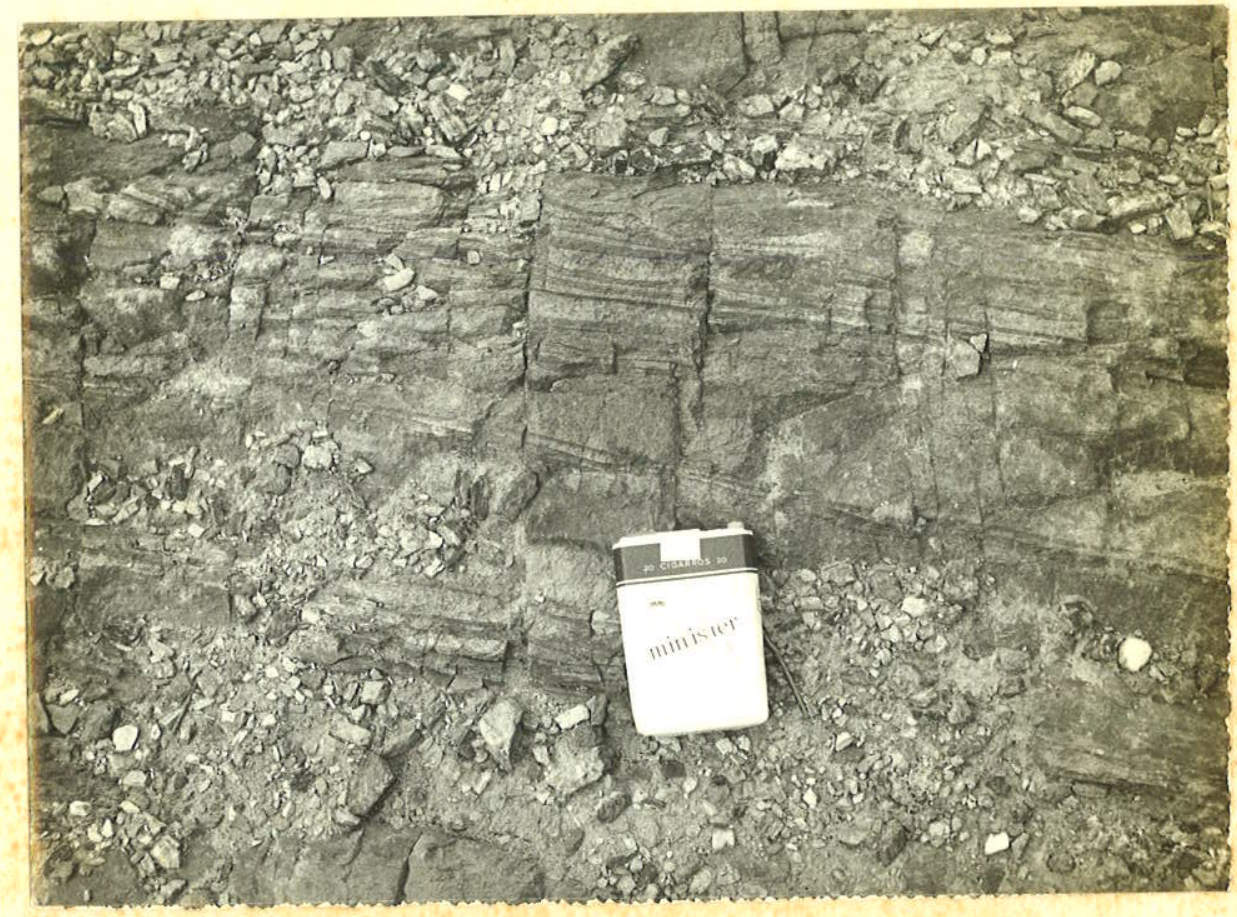

FOTO 18 - Juntas transversais à xistosidade

(coincidente com a estratificação nesse local). Rodovia Raposo Tavares, km 80, a $6 \mathrm{~km}$ de Brigadeiro Tobias para Alumínio. 
vemos em afloramentos juntas e pequenas falhas paralelas, co mo na Foto 19. Tais fatos confirmam a qualificação.

\section{ESTRUTURAS INTERNAS DOS MACIÇOS GRANITOOIDES}

Nos maciços sintectônicos estão presentes uma folia ção pronunciada, dada pela orientação sobretudo de micas, e sistemas de juntas. Os lineamentos fotogeológicos verificados nas suas áreas de exposição foram objeto de exame detido na Pedreira Dipedra (Maciço Sorocaba, em Sorocaba).

- diagrama $\pi$ da Figura 26 representa as juntas e a foliação observadas. Nota-se que a foliação, apesar de ondu lada, tem tendências gerais análogas às da xistosidade na área 3. Os sistemas de juntas coincidem com aqueles da área 3, comparecendo um sistema paralelo, outro transversal, dois oblíquos à foliação com atitudes subverticais. Um sistema de baixo mergulho também está presente. Pequenas zonas de atrito vinculam-se aos sistemas objúquos, permitindo qualifi cá-las como de cisalhamento.

Nos maciços pós-tectônicos não foi feito estudo dos lineamentos fotogeológicos. Observa-se que eles existem,mas em baixa densidade.

\section{REGIONALIZAÇÃO DOS DADOS ESTATİSTICOS}

Os dados estatísticos apresentados referem-se áreas 1, 2, 3 e 4 indicadas na Figura 10.

As medições e observações fora dessas äreas mostram que as relações estabelecidas entre lineamentos fotogeológicos, juntas subverticais e elementos das dobras (orientação de eixos, planos axiais, xistosidade e estratificaçãol são extrapoláveis regionalmente, embora variem as direções.

Por isso, nos mapas geológicos anexos dois grupos de lineamentos fotogeológicos foram separados: aqueles pertinen 


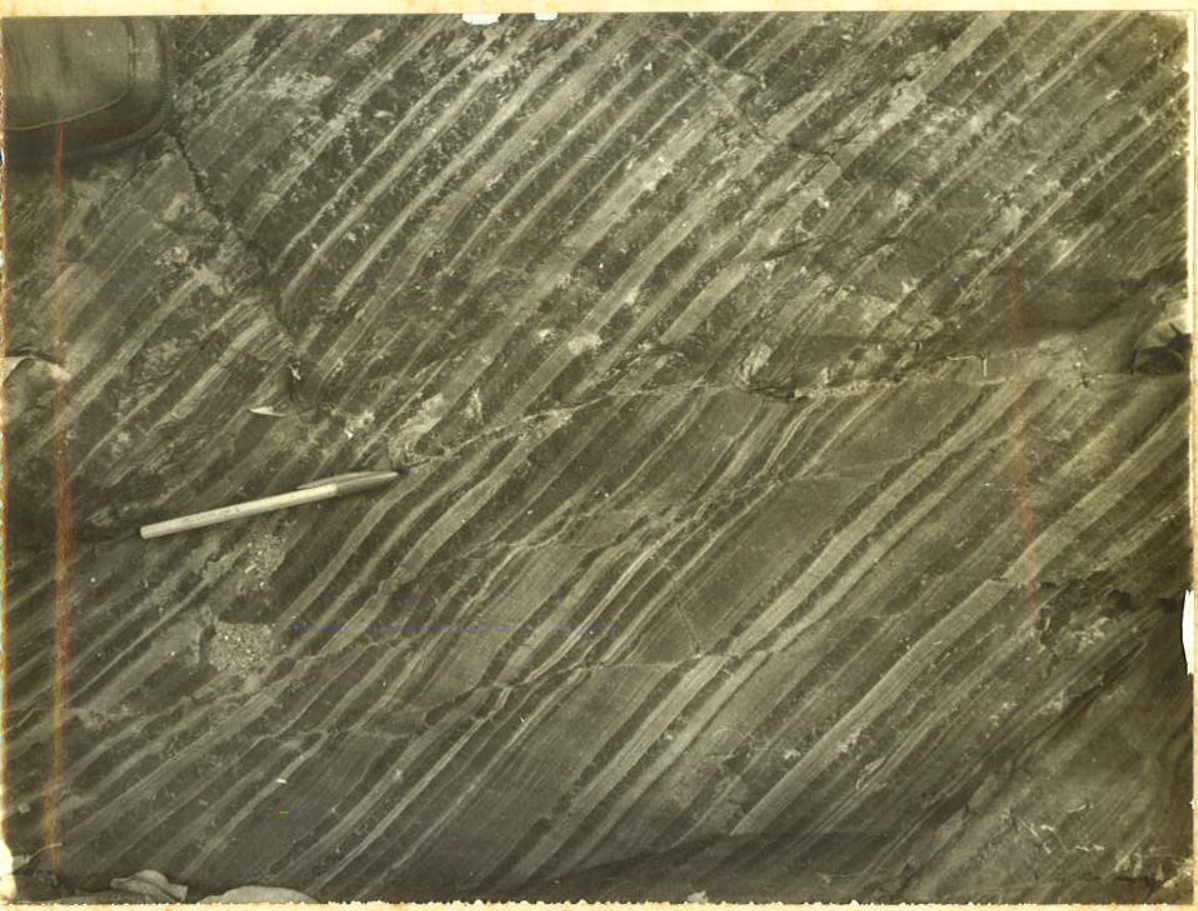

FOTO 19 - Juntas oblíquas à xistosidade (coincidente com a estratificação nesse locall; tais juntas frequen temente evoluiram para pequenas falhas. Rodoviā Raposo Tavares, $\mathrm{km} 80$, a $6 \mathrm{~km}$ de Brigadeiro Tobias para Alumínio. 
Fig. 26 - JUNTAS E FOLIAÇÄO DO MACIÇO GRANITÓIDE DE SÃO FRANCISCO

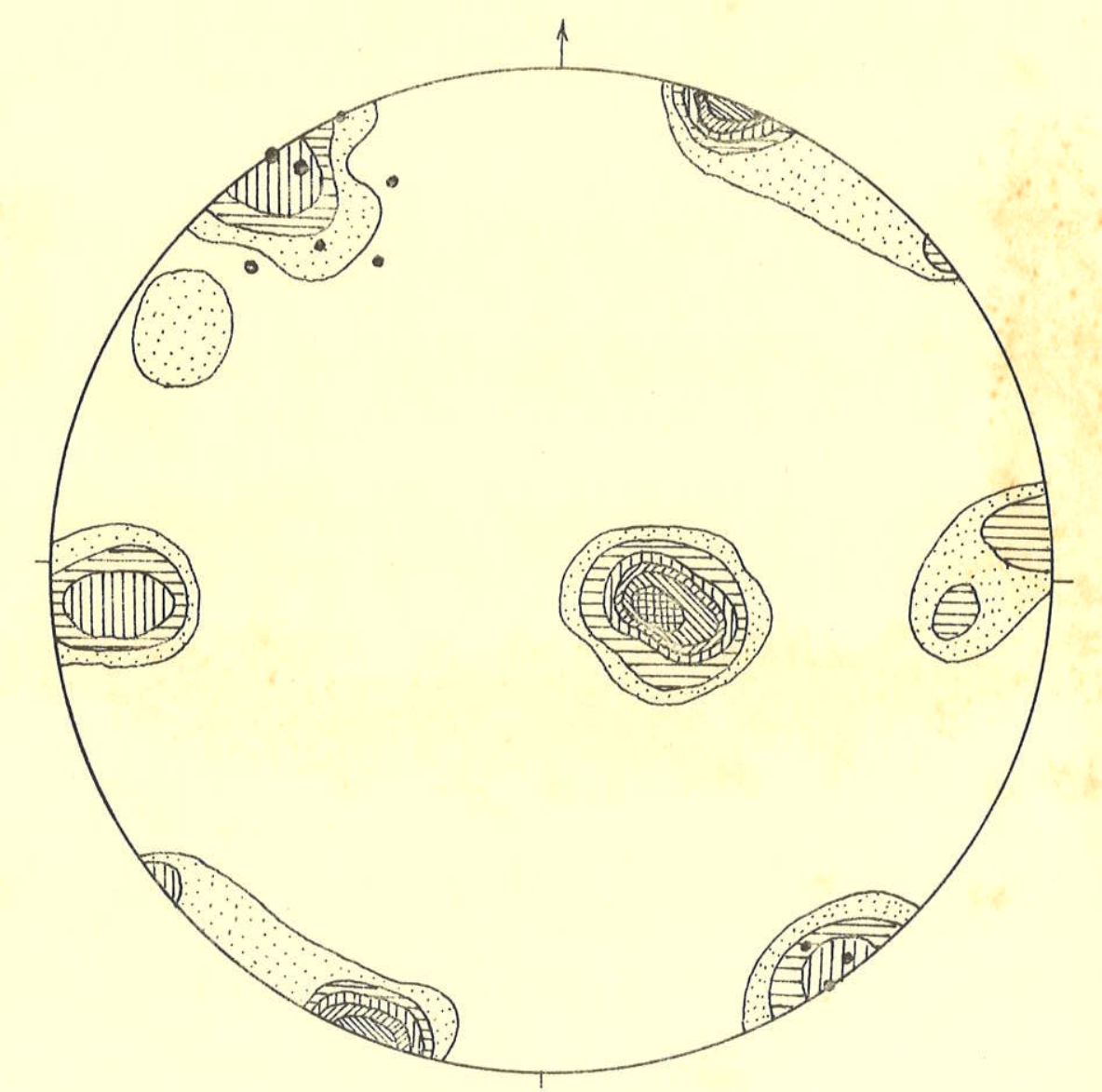

118 polos de juntos

- foliação

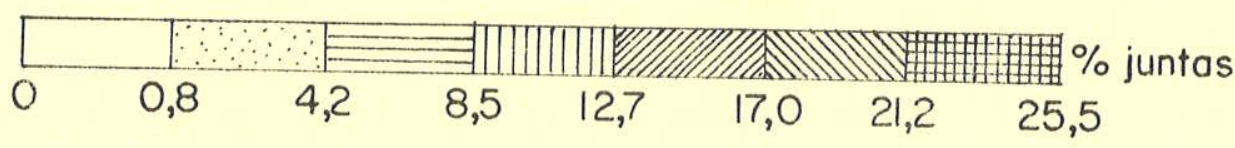


tes às juntas e aqueles que se relacionam com elementos de dobras nos metamorfitos ou com a foliação nos corpos grani tóides.

\author{
ANĀLISE DO DOBRAMENTO
}

BLOCOS SÃO ROQUE E ITUPARANGA

Nos Blocos São Roque e Ituparanga, como vimos, as do bras são configuradas pela estratificação (superfícies $S_{0}$ ), com a xistosidade em posição plano-axial (superfícies $S_{1}$ ). As duas superfícies citadas foram afetadas pelo desenvolvimento. em escala reduzida, de uma foliação de crenulação (Superfí cies $\left.S_{2}\right)$. Temos então, duas fases de deformação $\left(F^{\prime}{ }_{1}\right.$ e $\left.F^{\prime}{ }_{2}\right)$.

Convém notar que nas dobras cerradas (e, menos fre quentemente, isoclinais e fechadas)com planos axiais subver ticais, com flancos extensos e zonas apicais restritas, é muito frequente vermos segmentos em que $S_{0}$ concorda com $S_{1}$. Também em caso de transposição avançada, $S_{1}$ pode ser levada a coincidir com $\mathrm{S}_{2}$.

Em ambos os blocos, o dobramento é homoaxial ou coa xial (Whitten, 1966), e se deu segundo as duas fases de de formação acima citadas.

\title{
BLOCOS COTIA E JUQUITIBA
}

Aqui também os dobramentos guardam coaxialidade por extensas áreas. Deflexões existem, como indicam os lineamen tos nos mapas geológicos anexos a leste de pilar do sul e nos vale do rio são Lourenço, neste último associado a um pre sumido falhamento. 
O dobramento que se verifica é morfologicamente idên tico àquele dos outros dois blocos, com um importante deta lhe diferenciativo: a xistosidade aqui se apresenta concor dante com a estratificação reliquiar em todas as observações feitas, isto é, $S_{0}$ e $S_{1}$ coincidem. Essa concordäncia já foi citada anteriormente e mostrada nos diagramas das Figu ras 15,16 e 19.

Situações idênticas foram verificadas na Irlanda (Whitten, 1959), na Escócia (Sutton e Watson, 1959; Rast, 1958; Robert e Treagus, 1964), em Nova York (Craddock, 1957), nos Alpes suiços e em rochas antigas da África do sul (in Ramsay, 1967) e estudos de detalhe comprovaram sua relação com redobramento.

Numa primeira fase F"l ter-se-iam desenvolvido gran des dobras isoclinais ou cerradas recumbentes. Talvez até nappes tenham sido criados. A xistosidade $\left(S_{1}\right)$ nos flancos dessas dobras guardou paralelismo com a estratificação reli quiar ( $\left.S_{0}\right)$; nos ápices dessas dobras, porém, deve haver dis cordancias. Somente em estudos pormenorizados essas restritas zonas de discordância poderẽo ser caracterizadas, como o fizeram os citados autores nas áreas por eles estudadas. Ramsay (1967) chama atenção para o fato de, em se tratando de clobras de pequena abertura, tarnar-se dificil detectar os ápices dessas primeiras dobras.

o reconhecimento de um estilo de dobramento criando dobras recumbentes e até nappes não é de modo algum novidade. Em todas as reconstituições de dobramentos tem-se verificado uma fase inicial com esse estilo. Isso é particularmente ver dadeiro nas regiões alpinas, onde estudos mais pormenoriza dos foram realizados. Auboin (1965) considera essas estrutú ras como tipicas da zona eugeossinclinal, que se tombam para - lado do miogeanteclíneo, podendo até invadir a zona mio gessinclinal.

Chama a atenção o fato de não observarmos nas camą 
das sinuosidades típicas de redobramentos oblíquos ou cruza dos. Também eixos de dobras são retilíneos e os boudins não desenvolvem estruturas em "tabletes de chocolate". Tais fa tos fazem crer que o primeiro dobramento ( $F{ }_{1}$ ) criou dobras com eixos paralelos aos subsequentes.

Na segunda fase $\left(F^{\prime 2}\right)$, é que se superimpuseram as do bras observadas (cerradas, ocasionalmente fechadas e isocli nais, com planos axiais subverticais), como mostradas nas Fotos 13 e 15. As superfícies $S_{0}$ e $S_{1}$ são vistas em con cordância, inclusive nos ápices das ondulações (Foto 13, Fo tomicrografia 32 ).

A Fotomicrografia 34 mostra uma feição textural não rara nos Blocos Cotia e Juquitiba. Granadas contêm inclu sões alinhadas segundo direções discordantes com a xistosida de. Isso indica que a granada cresceu após desenvolvida a xistosidade e que depois ela sofreu rotação. A Fotomicrogra fia 34 é um detalhe de flanco de uma dobra e aparentemente essa rotação se relacionaria com esse dobramento $\left(F_{2}\right)$ mostra do na Fotomicrografia 31 . Como descrevemos antes, às vezes a granada mostra inclusões heliciticas, sugerindo que a for mação delas já começara na época de um dobramento anterior $\left(F_{1}\right)$, durante o qual a xistosidade já se desenvolvera.

Esse tipo de relação tem sido investigada por numero sos autores, destacadamente por Zwart (1963) nos Pirineus, permitindo relacionar eventos metamórficos e tectónicos. No caso presente, podemos concluir a seguinte sucessão:

1 - dobramentos $\mathrm{F}^{1}$, com metamorfismo regional desen volvendo xistosidade plano-axial;

2 - desenvolvimento de granadas que se iniciou ao fim da fase $F_{1}$ ou terminou no começo de $F_{2}$;

3 - dobramento $F^{\prime 2}$, afetando as dobras anteriormente criadas. Rotação das granadas.

0 modelo de redobramento $\left(F_{1}+F_{2}\right)$ acha-se esquema- 


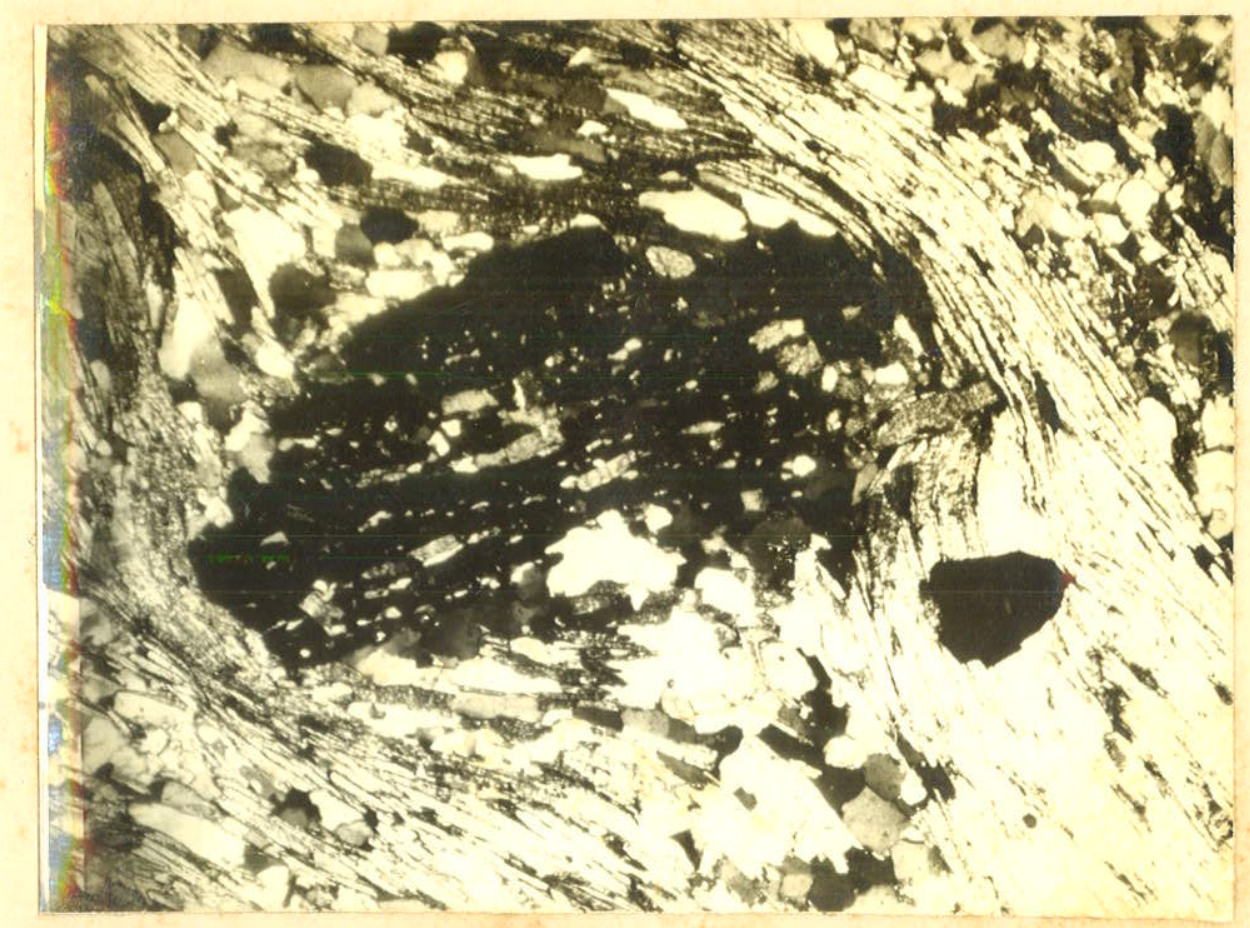

FOTOMICROGRAFIA 33 - Porfiroblastos de granada poiquiloblastica em micaxisto. O alinhamento das inclusões indica ro tação posterior à formação do porfiroblasto; esse movimen to parece relacionar-se com o dobramento mostrado na fotomicrografia 31 . Note-se seção basal de turmalina euédrí ca no canto direito inferior.

$192 \times \mathrm{N}+$. Amostra 234, $7 \mathrm{~km}$ a ENE de Pilar do sul.

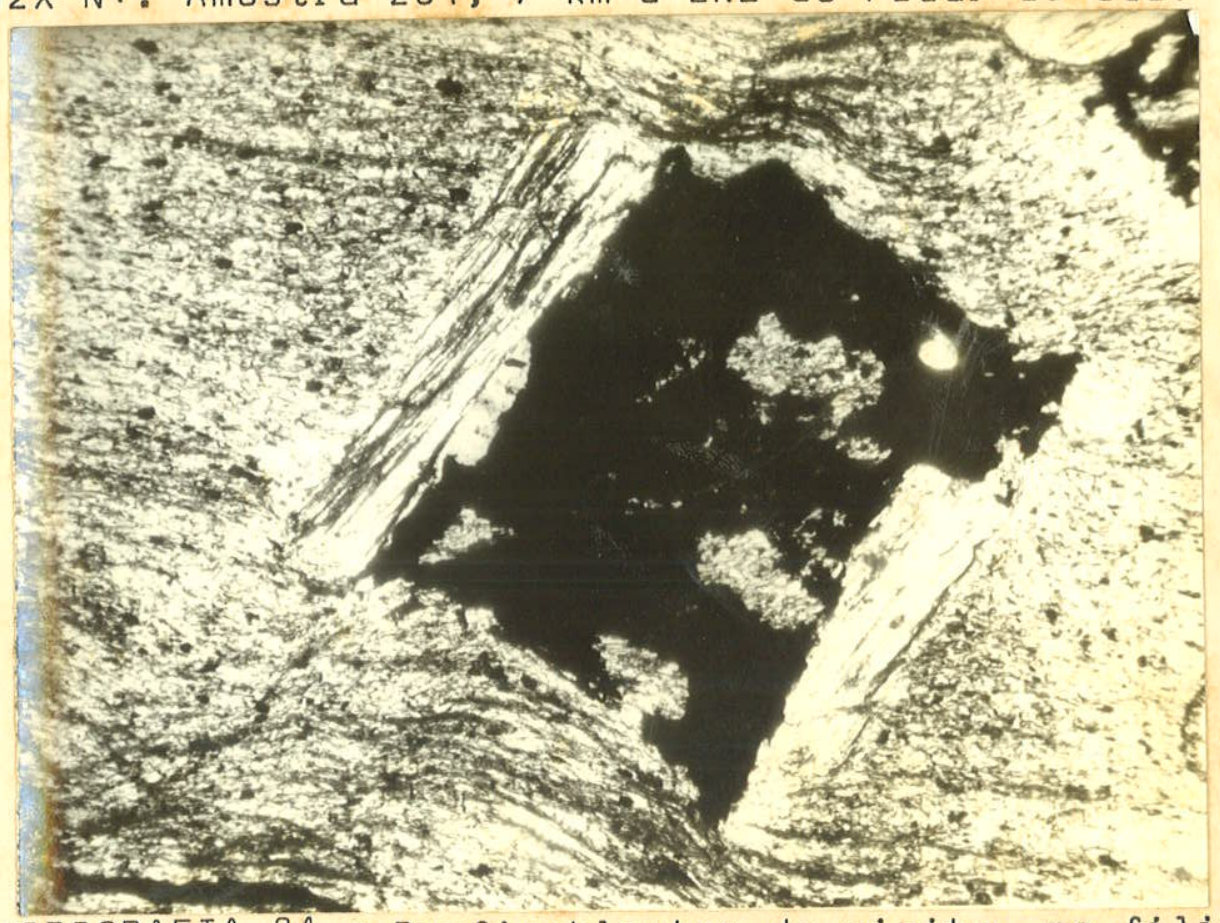

FOTOMICROGRAFIA 34 - Porfiroblastos de pirita, no filito. As inclusões de filito guardam a orientação da matriz ondu lada anteriormente à formação do porfiroblasto. Porfiró blastos de moscovita cresceram nas zonas de sombra do cristal de pirita. As ondulações do filito são devidas a foliação de crenulação(ver fotomicrografia 24). $480 \times \mathrm{N}+$. Amostra 223, $6 \mathrm{~km}$ a SE de Pilar do Sul. 
Fig. 27 - DOBRAMENTO $F_{1}$ E REDOBRAMENTO $F_{2}$ SUPERIMPOSTO
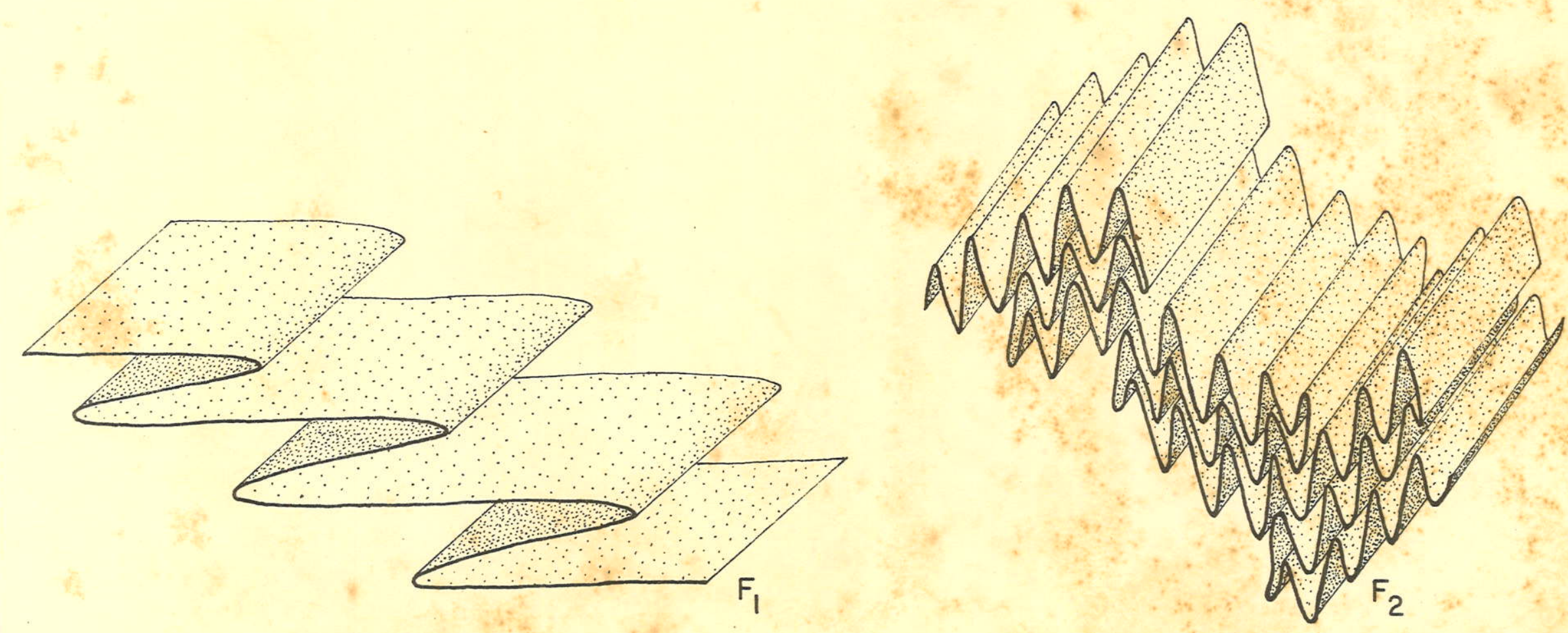
tizado na Figura 27.

Por fim, tal como nos Blocos São Roque e Ituparanga, aqui também se desenvolveu a foliação de crenulação,promoven do dobramentos de pequena escala $\left(F_{3}\right)$. É interessante notar que nos dois blocos setentrionais, a crenulação foi de modo geral discreta; no Bloco Cotia já se nota um grau mais avançado e generalizado e no Bloco Juquitiba, a transposição não raramente chegou a se completar, o que indica um aumento de intensidade no rumo SE.

Na Fotomicrografia 34 mostramos uma feição comum nas bordas do Granito de Pilar do sul. D porfiroblasto de piri ta trunca a xistosidade e contém inclusões que guardam a orientação da matriz. Nas zonas de sombra desenvolveram-se porfiroblastos de moscovita. A piritização do xisto é niti damente posterior ao desenvolvimento da crenulação, como se vê na Fotomicrografia 24. Mesmo na Fotomicrografia 34 os por firoblastos se desenvolveram na faixa entre dois planos de cisalhamento, os quais são responsáveis pela ondulação da xistosidade.

Dessa feição podemos inferir a seguinte sucessão de eventos:

$$
\begin{aligned}
& 1 \text { - desenvolvimento da crenulação (fase } F_{3} \text { ); } \\
& 2 \text { - crescimento dos porfiroblastos, em conexão com a }
\end{aligned}
$$
intrusão granítica.

Esses eventos são a continuação daqueles retro-citados e poderiam ser numerados 4 e 5 , assim completando o qua dro de relações entre alguns eventos metamórficos e o tectó nismo.

As fases de dobramento descritas, podem ser correla cionadas com base nos seus estilos. 
Assim, a fase F" 1 dos Blocos Cotia e Juquitiba, carac terizada por dobras recumbentes, isoclinais ou cerradas, não tem correspondência nos dois outros blocos.

Já a fase $F "{ }_{2}$ dos dois blocos meridionais e a fase $F^{\prime} 1$ dos dois setentrionais se caracterizam pelas dobras cer radas (ocasionalmente isoclinais e fechadas) de planos axiais subverticais.

As fases $\mathrm{F}^{\prime \prime} 3$ e $\mathrm{F}^{\prime} 2$ também são análogas, gerando uma foliação de crenulação, mais acentuadas no rumo sudeste.

Podemos, então, como síntese, reconhecer para a área estudada três fases $F_{1}, F_{2}$ e $F_{3}$ sucessivas sendo a primeira restrita aos Blocos Cotia e Juquitiba.

Os eventos metamórficos e magmáticos são relacioná veis a essas fases de deformação através de dados de análise microtextural e de relações de campo.

0 metamorfismo regional $\left(M_{1}\right)$ deu-se contemporâneamen te a $F_{1}$ nos Blocos Juquitiba e Cotia. Já nos Blocos são Ró que e Ituparanga, sendo a xistosidade do tipo plano-axial, o metamorfismo regional deve ter-se dado em conjunção com a fase $F_{2}$. No intervalo entre $F_{1}$ e $F_{2}$ houve formação de por firoblastos de granada $\left(M_{2}\right)$, a qual ou começou ao fim de $F_{1}$ ou terminou no início de $F_{2}$ pois há texturas helicíticas ocasionais.

Ao fim da fase $F_{2}$ deram-se as intrusões sintectônicas, impondo metamorfismo de contato $\left(M_{3}\right)$ às encaixantes.

Após a fase $F_{3}$ é que se deram as intrusões pós-tectó nicas, responsável pela incidência de metamorfismo de contá to $\left(M_{4}\right)$ nas encajxantes.

Por fim, sobrevieram os falhamentos transcorrentes, resultantes de um novo regime de esforços (fase $F_{4}$ de deformação) e que levaram as rochas a sofrerem metamorfismo cata clástico $\left(M_{5}\right)$. 
Quanto ao evento retrometamórfico $\left(M_{6}\right)$, ele foi indi cado por Coutinho (1972) no Bloco Juquitiba. Faltam-nos da dos para melhor caracterizá-lo.

Se considerarmos o Falhamento de Taxaquara, com seu rejeito mínimo de $150 \mathrm{~km}$ (Hennies et al., 1967) e o seu ca ráter dextral, concluimos que os Blocos São Roque e Ituparan ga originalmente estariam bastante a oeste de sua posição atual. Os demais falhamentos são secundārios e não devem ter imposto deslocamentos de tal monta. Adicionalmente, se con siderarmos a distribuição de fácies metamórficas, com os Blo cos São Roque e Ituparanga mais a oeste, podemos constatar um nítido zoneamento, com litologias da fácies xisto verde a ocidente e da fácies anfibolito a oriente.

Nesse contexto, incluímos agora um zoneamento estru tural. A fase $F_{1}$ se restringiu a uma zona oriental, enquan to as fases $\mathrm{F}_{2}$ e $\mathrm{F}_{3}$ incidiram em toda a região. Em outros termos, o que Hasui et al. (1969) denominaram Grupo São Roque tem uma história tectônica mais simples do que o restante. É possível que no sul do Estado de são Paulo, como no Paraná, as duas zonas estruturais estejam pareadas normalmente, sem interferências de grandes falhamentos.

\section{ESTRUTURAS DA BACIA DO PARANĀ}

Na área da Bacia do Paraná que se inclui na Folha de Pilar do Sul, o exame das fotografias aéreas mostra a exis tência de lineamentos conspícuos, condicionando a drenagem ea forma dos interflúvios. Tais lineamentos estão assinalados na Figura 28.

Nota-se que esses lineamentos são concordantes com aqueles presentes no embasamento, quer no Bloco São Roque, It paranga ou Cotia, o que se salienta quando comparamos a rosá cea da Figura $29 \mathrm{com}$ os lineamentos indicados nas folhas geológicas anexas. Tal concordância dificilmente pode ser 


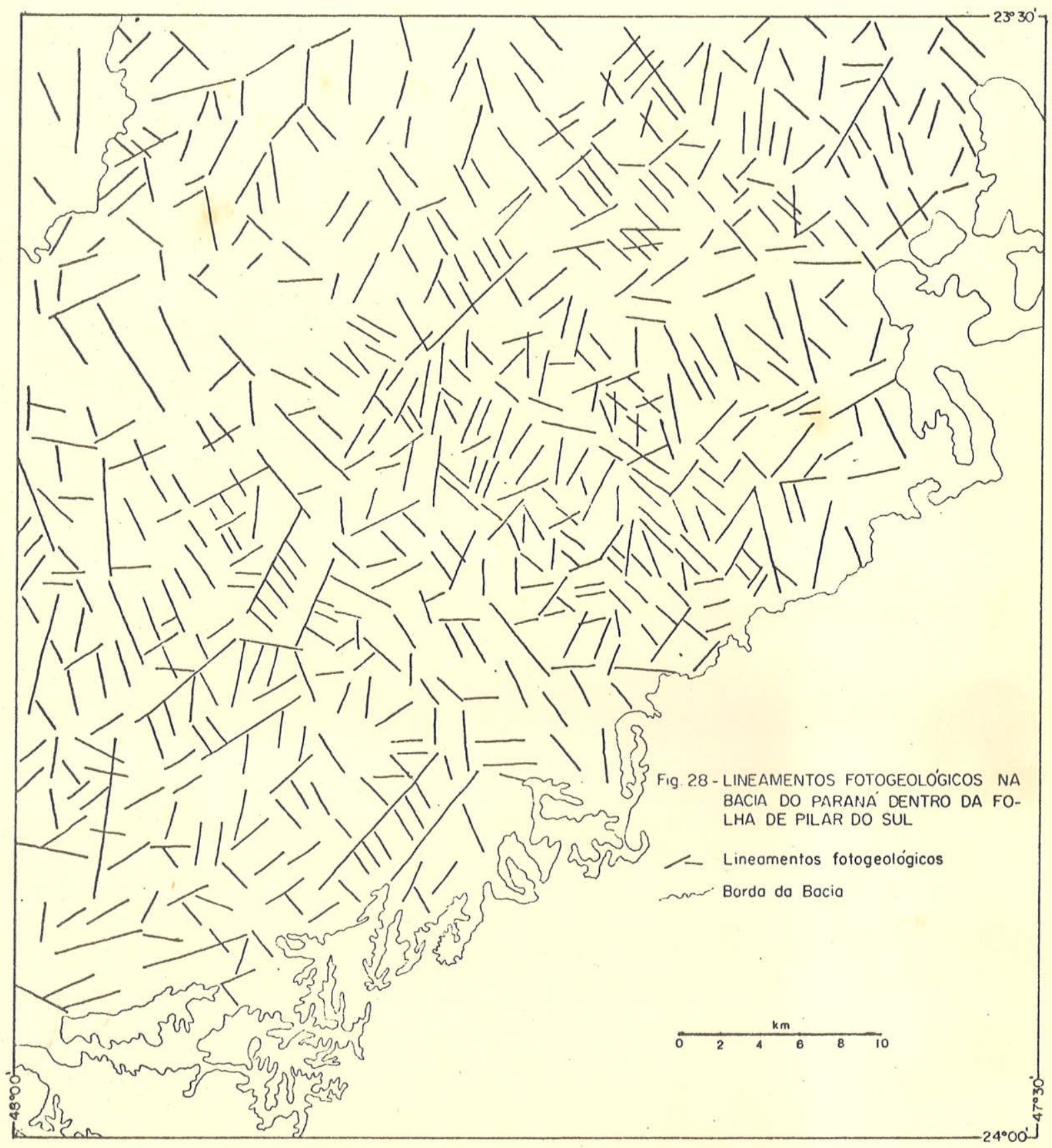


Fig. 29 - ROSÁCEA DOS LINEAMENTOS FOTOGEOLÓGICOS DA BACIA DO PARANA' NA FOLHA DE PILAR DO SUL

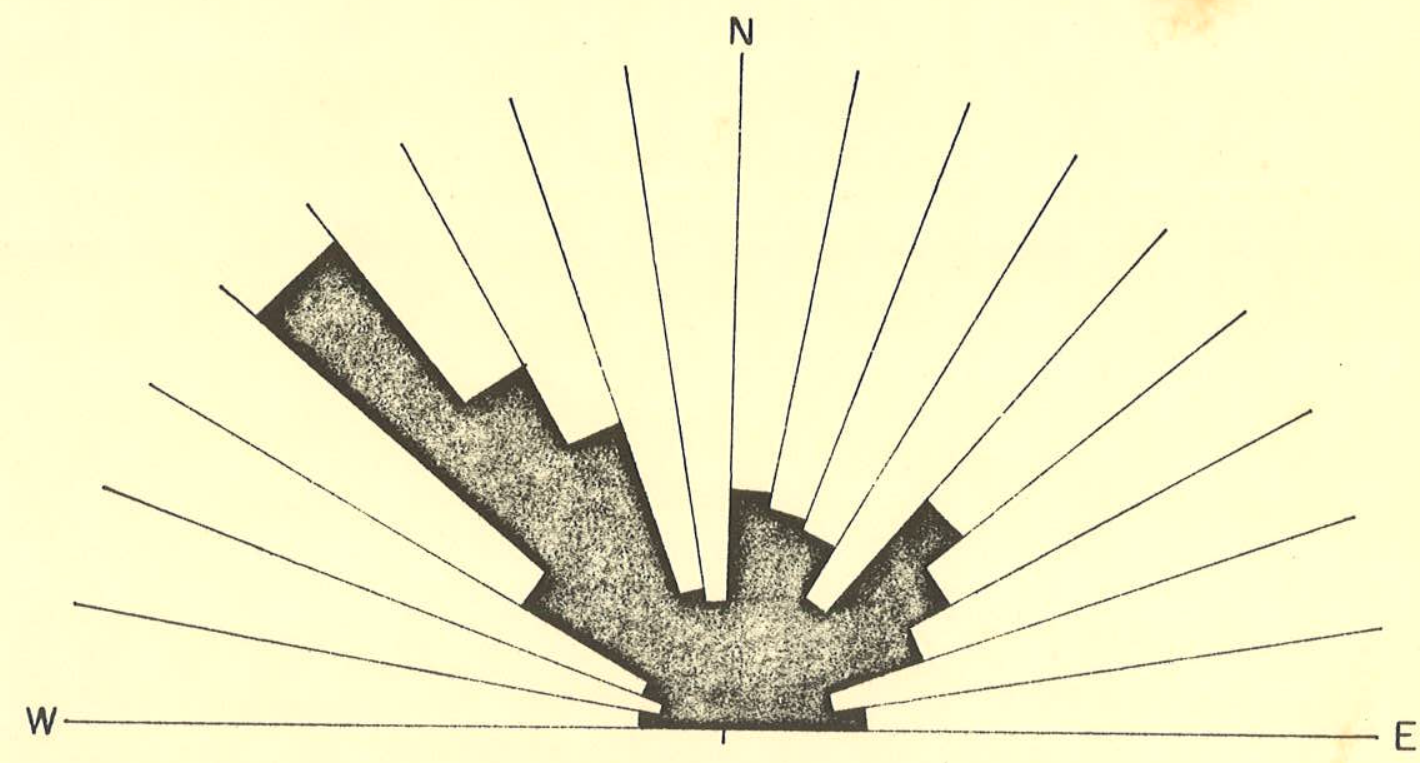

570 lineomentos

ESCALA RADIAL $1 \mathrm{~cm} .=2,5 \%$ 


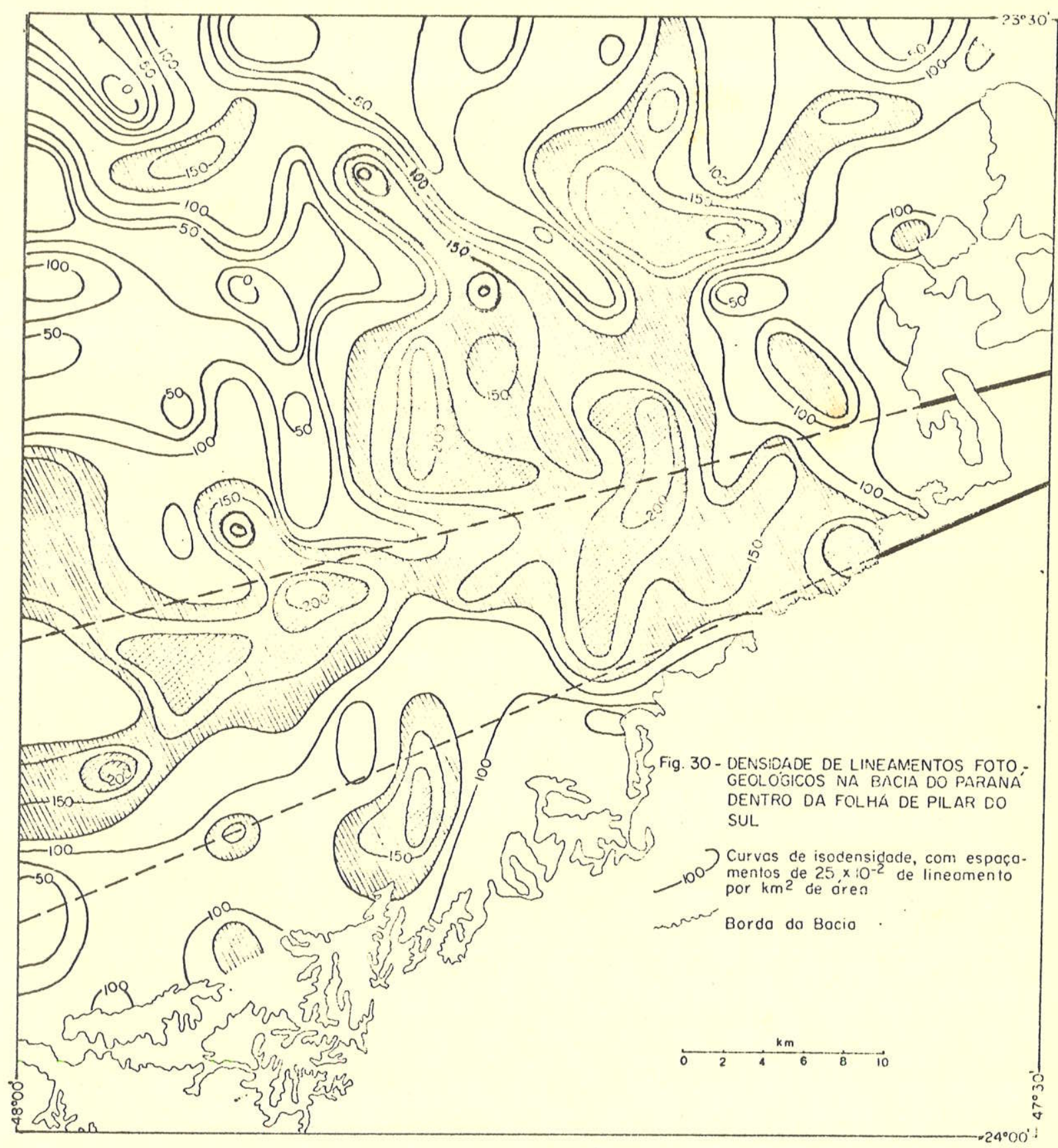


considerada casual; ao contrário, parecem relacionar-se a re flexos de reativações de lineamentos do embasamento.

Na Figura 30 apresentamos um mapa de densidades de lineamentos, expressos em quilômetros de lineamentos por quí lômetro quadrado de área. Nota-se que as zonas de maior den sidade parecem relacionar-se:

a) com a borda da Bacia do Paraná. No canto noroes te da Folha de Pilar do Sul, as densidades são sensivelmente inferiores, e

b) com uma faixa no prolongamento do Bloco Ituparanga para oeste.

Estudos de áreas maiores se fazem necessários para confirmar essas tendências assinaladas. 


\section{CAPITULO 9 - ANĀLISE GEOCRONOLŌGICA}

Neste trabalho, nenhum dado geocronológico novo é apresentado, mas não é possível deixar de mencionar os re sultados já conhecidos, que interessam ao Pré-Cambriano pau lista e, mais de perto, à evolução da Faixa Dobrada do Ri beira. Algumas das amostras que foram analisadas, inclusive, provieram da área ora focalizada.

Os estudos de Cordani e Bittencourt (1967), Cordani e Kawashita (1971) e Hasui e Hama (1972) procuraram estabe lecer idades de eventos reconhecidos na Faixa Ribeira. Me $\bar{l}$ cher et al. (1973) apresentaram a sintese seguinte, com ba se naqueles estudos:

$$
\begin{aligned}
& >650 \mathrm{~m} \cdot \mathrm{a} \text {. - Sedimentação do Grupo Açungui. } \\
& \text { - } 650 \mathrm{m.a} \text { - Fase "orogenética" principal. } \\
& \text { Formação de granitos sintectônicos. } \\
& \text { 600-650 m.a. - Intrusão de granitos tardi-tectôni- }
\end{aligned}
$$

Em que pesem algumas dificuldades interpretativas de alguns resultados, dada a falta de estudos geológicos mais acurados dos corpos geológicos datados, tal esquema tem- se mantido desde o estudo de Cordani e Bittencourt (1967). Indica ele que os eventos são atribuíveis ao Ciclo Brasilia no (AZmeida, 1967), durante o qual se desenvolveu a Faixa Ribeira. 


\section{CAPITULO 10 - EVOLUÇÃO TECTÕNICA DA ĀREA DAS FOLHAS DE PILAR DO SUL E DE SAOO ROQUE}

Os dados referentes à litologia mostram que os qua tro blocos são essencialmente análogos em sua constituição. Assim, metapelitos e metapsamitos são, de longe, os termos predominantes em toda área; rochas calcárias e/ou calcosili catadas formam intercalações pouco desenvolvidas e metabasi tos constituem ocorrências esparsas. As diferenças são sü tis e uma merece destaque: rochas calcárias e/ou calcosili catadas têm expressão maior no Bloco Sãó Roque, inclusive mé recendo representação nos mapas geológicos anexos; estão au sentes no Bloco Ituparanga e formam ocorrências muito discré tas nos Blocos Cotia e Juquitiba.

Pela análise do metamorfismo, vimos que rochas da fá cies xisto verde comparecem nos Blocos São Roque. Ituparanga e parte ocidental do Bloco Cotia. No Bloco Juquitiba e na parte oriental do Bloco Cotia aparecem termos da fácies anfi bolito. Lá as rochas são ectiníticas e aqui são migmatitos de estrutura estromatítica ou oftalmítica.

As litologias descritas não diferem entre si a não ser quanto ao grau de metamorfismo e à migmatização e não há razão para considerar os migmatitos como uma unidade à parte sob o nome Complexo Cristalino. Todos os metamorfitos da ārea integram uma só unidade estratigráfica, o Grupo Açungui.

Em termos de subdivisão estratigráfica podemos efeti vamente reconhecer uma sequência metapelítica com intercala ções lenticulares metapsamíticas, sotoposta a um pacote de metapelitos com intercalações calcárias/calco-silicatadas. No topo, está presente um conjunto de metapelitos e metapsamitos com estrutura rítmica ou cíclica; esta unidade constitui cer ca de $90 \%$ dos metamorfitos expostos. Essas sequências toda via não têm limites claros, razão porque apontamos as áreas 
de incidência, sem distinguílas nos mapas geológicos anexos. No nível atual de conhecimento esboços, como o da figura 31 , podem ser apresentados, restritos às áreas epimetamórficas.

Essas sequências corresponderiam à sequência terríge na inferior, à carbonatada e à terrígena superior de Beloussov (1962) e, assim colocadas, podem ser correlacionadas, respec tivamente, com as Formações Setuva, Capiru e Votuverava do Estado do Paraná.

Quanto ao magmatismo, três fases foram identificadas: a pré-tectônica, de natureza básica, responsável pela consti tuição dos corpos metabasíticos que se acham penetrados na sequência metassedimentar superior; a sintectônica, de cará ter ácido, representada por numerosos corpos sintectônicos parautóctones constituídos pelo chamado "Granito" tipo Piri tuba; a pós-tectônica representada pelos Maciços de Pilar do Sul, Turvo e Serra do Lopes.

A análise estrutural revela três fases principais de dobramento: na fase $F_{1}$, restrita aos Blocos Juquitiba e Co tia, formaram-se dobras recumbentes ( e nappes?) isoclinais ou cerradas; na fase $F_{2}$, as dobras geradas por toda a área são cerradas (às vezes fechadas e isoclinais) com planos axiais subverticais; na fase $F_{3}$, as dobras que se constitui ram são microscópicas a decimétricas, geradas por cisalha mentos; tendo uma foliação de crenulação em posição plano-axial. Esta última fase foi também generalizada, mas com maior intensidade para SE.

A análise microtextural indica que o metamorfismo re gional $\left(M_{1}\right)$ se deu contemporâneamente à fase $F_{1}$ nos Blocos Juquitiba e Cotia e à fase $F_{2}$ nos Blocos Ituparanga e São Ro que.

Após a fase $F_{1}$ desenvolveram-se cristais de granada (evento metamórfico $M_{2}$ ) sob forma de porfiroblastos. Esse processo começou no fim de $F_{1}$ ou terminou no começo de $F_{2}$, pois texturas heliciticas chegaram a se desenvolver. 
Fig. 31- SUBDIVISÕES DO GRUPO AÇUNGUI NA ÁREA ESTUDADA

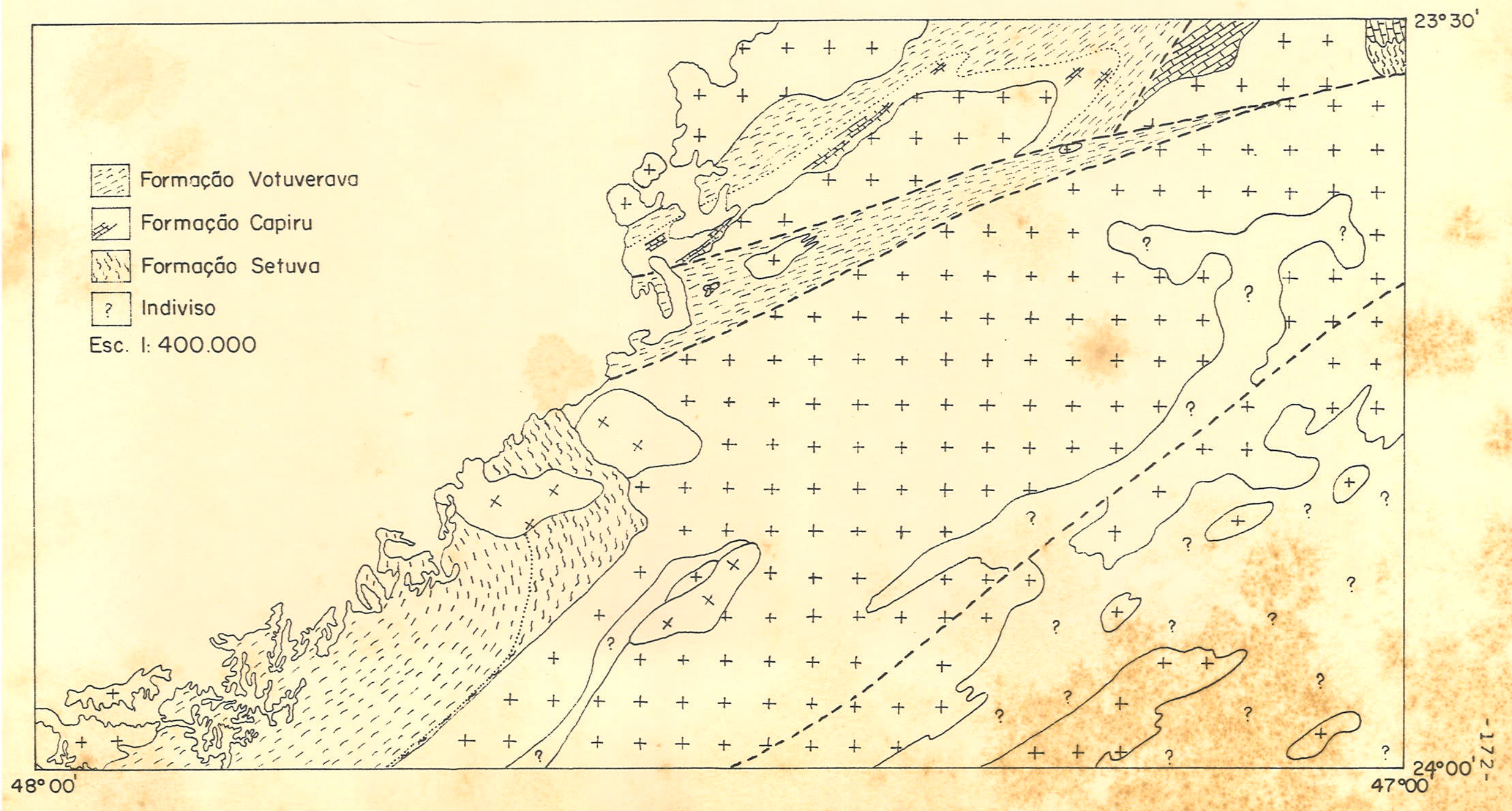


No fim da fase $F_{2}$ deram-se as intrusões sintectônicas $\left(I_{2}\right)$. A feldspatização tardia começou quando ainda vi giam esforços dirigidos, mas prolongou-se ainda após a dissipação dos mesmos. Metamorfismo de contato ( $M_{3}$ ) nas encai xantes se deu em conexão com essas intrusões.

Mais tarde, após a fase $F_{3}$, processaram-se as intru sões pós-tectônicas, que também impuseram transformações de contato $\left(\mathrm{M}_{4}\right)$.

Por fim, na história da área se reconhece uma fase de deformação $\left(\mathrm{F}_{4}\right)$ importante pelos enormes falhamentos trans correntes que gerou. As rochas atingidas sofreram metamor fismo cataclástico $\left(M_{5}\right)$ em graus variados, transformando-se em brechas tectônicas, flaser-gnaisses, augen-gnaisses, mi lonitos, filonitos e ultramilonitos.

Uma fase de metamorfismo diaftorético parece ter ocorrido, pelo menos no Bloco Juquitiba (Fase $M_{6}$ ) de acordo com Coutinho (1972).

Com todos esses elementos essenciais e outros ante riormente expostos, somos conduzidos ao seguinte quadro de evolução tectônica da área estudada:

Inicialmente houve sedimentação, acompanhada de mag matismo básico, num ortogeossinclíneo (Kay, 1947; Auboin, 1965; Beloussov, 1962).

Vários modelos de evolução geossinclinal foram já propostos e eles mostram que há peculiaridades distinguindo diferentes geosinclíneos e mesmo partes de um mesmo geos sinclíneo. Todavia, os fatos principais e gerais são co muns (Muratov, 1968; Khain e Muratov, 1968; Hermes, 1968; MikhayZov, 1970; Gnibidenko e Shashkin, 1970, etc.l Tal é o caso do estágio de evolução geossinclinal, no qual se ma 
nifesta subsidência criando depressões. Estas são preenchi das de sedimentos e se sujeitam a magmatismo, talvez devido ao advento de profundas geofraturas em regime tracional. Es se magmatismo é em geral de caráter básico elou ultrabásico, constituindo corpos genericamente denominados ofiólitos (Ustyev, 1970).

Sobreveio uma fase de dobramento, criando dobras iso clinais ou fechadas recumbentes (e nappes?) nos Blocos Co tia e Juquitiba (fase de deformação $F_{1}$ ). Contemporâneamente se processou metamorfismo em fácies xisto verde a anfibolito (fase de metamorfismo $M_{1}$ ), com desenvolvimento de xistosidade plano-axial. Um processo de formação de granadas teve lu gar em seguida $\left(M_{2}\right)$. Não sabemos ainda se ela começou já aó fim de $F_{1}$ ou se terminou ao início de $F_{2}$; uma dessas alter nativas explica as texturas heliciticas.

Essa série de eventos deve ter-se processado durante a inversão do geossinclíneo. Em todos os esquemas evolutivos, como já frisamos anteriormente, nas primeiras deformações constituem-se dobras io tipo descrito (v.g., Auboin, 1965).

( I I )

Nesta fase vários eventos tiveram lugar. Os dobramen tos (fase $F_{2}$ ) são cerrados (ocasionalmente isoclinais e fe chados), com planos axiais subverticais, e atingiram toda a área. Ao fim de $F_{2}$ deu-se o magmatismo sintectónico parau tóctone $\left(I_{2}\right)$, impondo transformações de contato às encaixan tes $\left(M_{3}\right)$. É de se notar que antes de ocorrerem estas intrú sões, nos Blocos São Roque e Ituparanga já havia terminado a fase $M_{1}$ de metamorfismo regional, pois os fenômenos de con tato afetaram rochas foliadas. Esse metamorfismo regional 
se deu em fácies xisto verde e sob a vigência de esforços compressivos, já que a xistosidade guarda posição plano-axial.

( IV)

Um dobramento final, por cisalhamento, de porte mui to discreto teve lugar (fase $F_{3}$ ). Criou ele crenulações da xistosidade e da estratificação. Com esse evento, os esfor ços compressivos se dissiparam, marcando o fim do processo de inversão da faixa lábil. O geossinclíneo deixou de exis tir transformando-se numa faixa dobrada (Khain e Muratov, 1968).

( V)

Intrusões graníticas pós-tectônicas se formaram (fa se $\left.I_{3}\right)$, impondo aos metamorfitos encaixantes transformações nas zonas de contato (fase de metamorfismo $M_{4}$ ).

0 magmatismo pós-tectônico relaciona-se com o está gio de orogênese de evolução da faixa lábil (Ustyev, 1970), em condições paraplataformais. Na região em foco, como de resto no Estado de São Paulo, não foram ainda observados depósitos de molassa e vulcânicas associadas como no Paraná, Santa Catarina e Rio Grande do Sul.

Falhamentos transcorrentes se processaram em seguida à fase de magmatismo I 3 , sob ação de esforços com uma compo nente compressiva principal segundo E-W. Hennies et al. (1967) chamaram essa fase de regmagênica, mas talvez seja preferível denominá-la lineagênica (HilZs, 1963), por causa das implicações daquele termo com eventos de escala univer sal imaginados por R.A. Sonder. Os movimentos transcorren tes possibilitaram metamorfismo cataclástico ao longo de faixas extensas e de largura até quilométrica (fase $M_{5}$ ).

Quanto au metamorfismo retrógado $\left(M_{6}\right)$, foi assinala do por Coutinho (1972), mas estudos de maior detalhe ainda 
devem ser realizados na área ora focalizada para poder carac terizá-lo perfeitamente.

No fim do Paleozóico (Permiano e Carbonífero), já em condições ortoplataformais (Almeida, 1969), deu-se a subsi dência e acumulação de sedimentos na região oeste da área estudada. Tais coberturas da plataforma exibem lineamentos, que não pudemos qualificar mas atribuíveis a reativações de estruturas do embasamento.

\section{(VII)}

No Juro-Cretáceo, a área foi afetada pela chamada Reativação Wealdeniana (Almeida, 1967), a qual se pode vincu lar o dique de diabásio da Serra de Inhaíba, as rochas alca linas de Piedade e possivelmente também a sedimentação ter ciāria.

Referíveis ao tempo anterior a esse tectonismo, isto é, ao Triássico e Jurássico, nenhum evento ou corpo rochoso é constatado. Presumivelmente, movimentos epeirogênicos po sitivos preponderaram.

Essa história evolutiva acha-se esquematizada na Figura 32.

Na situação atual, dentro da faixa de rochas antigas, observam-se entidades estratigráficas, estruturais, metamórficas e magmáticas, que não devem ser confundidas. A Figura 33 esquematiza as relações entre essas entidades. Note-se que o que anteriormente chamamos Grupo são Roque (Hasui et al., 1969) corresponde a uma região $X$.

Considerando o Falhamento de Taxaquara tal como atual mente concebido, os Blocos São Roque e Ituparanga ter-se-iam situado originalmente a pelo menos $150 \mathrm{~km}$ a oeste. Com isso, 
Fig. 33 - RELAÇÕES ENTRE ENTIDADES ESTRATTIGRÁFICAS, METAMO'RFICAS E TECTÔNICAS DA ÁREA

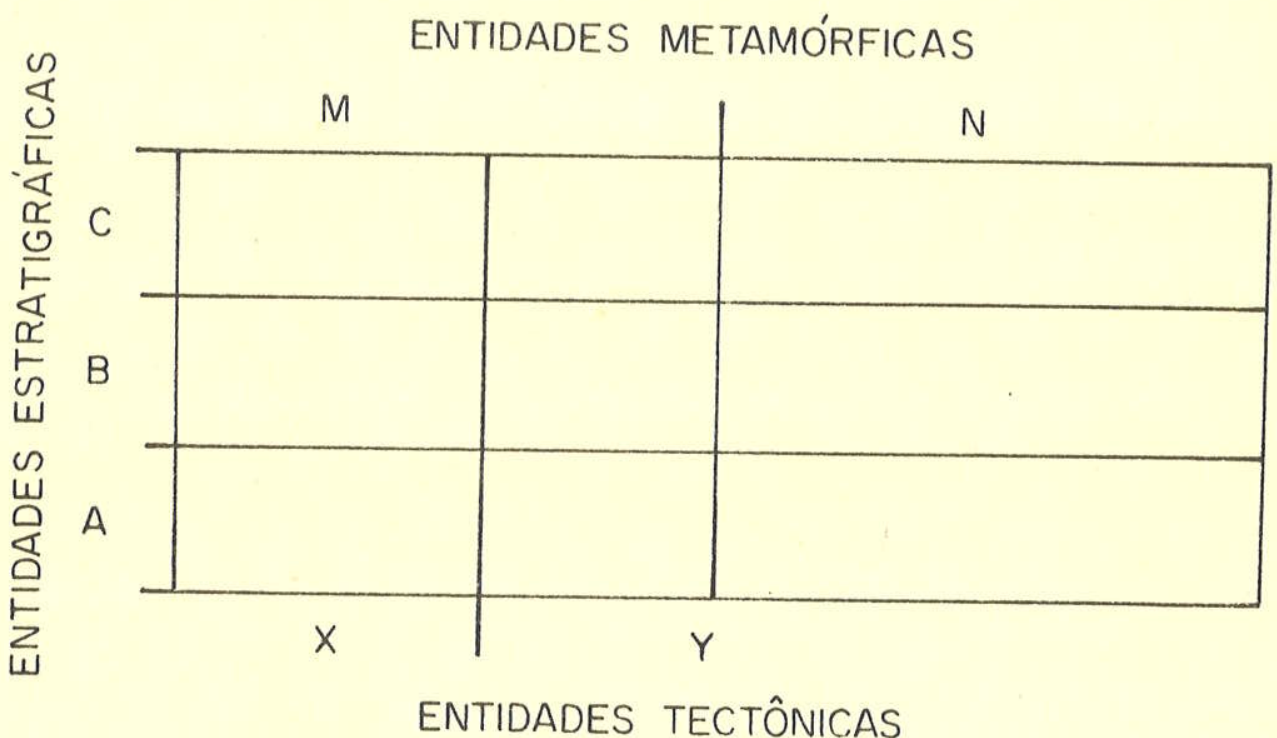
A - Sequência terrígena inferior
$B$ - Sequência carbonatada
C - Sequência terrigena superior
$M$ - Região de fácies metamórficas de baixo grau
$N$ - Regiäo de fácies metamórficas de alto grau
$X$ - Região dobrada com foliaçáo plano-axial
$Y$ - Região com dobramentos complexos 
torna-se patente um zoneamento metamórfico decrescente de SE para NW, bem como um zoneamento estrutural, passando-se da região $Y$ para a região $X$. Tais zoneamentos caracterizam uma polaridade (Auboin, 1965) de SE para NW. Essa polaridade é realçada também por outros fatos, como a incidência mais conspícua de rochas calcárias/calcosilicatadas a NW e a in tensidade decrescente da fase F 3 de SE para NW. as vergên cias, como vimos, não são claras; talvez um estudo das do bras da fase $F_{1}$ venha a definíla.

Auboin (1965) mostra que dobramentos como os da fa se $F_{1}$ restringem-se à zona eugeossinclinal, tombando-se con tra o miogeanticlíneo, chegando eventualmerite até a atingir o miogeossincíineo. Diante desse modelo, a região y corres ponderia ao eugeossinclíneo e a região $X$ ao miogeossinclíneo. Em termos litológicos, não é possível definir as zonas mioe eugeossinclinais, porquanto não constatamos a incidência de magmatismo ultrabásico.

Essa indefinição é típica de faixas dobradas do tipo hercínico, de acordo com Zwart (1967). Esta qualificação mais se firma, quando consideramos a abundância de corpos magmáticos ácidos e o metamorfismo configurando a série new- hampshireana ou barroviana, conforme já enfatizado por F.F. M. de Almeida (informacão verbal).

De momento, parece-nos caracterizado um ortogeossin clíneo, em relação ao qual o craton (plataforma) estaria a NW, sob a área da Bacia do Paraná, concordando com as conclu sões de Marini et al. (1967), Melfi et al. (1965), Hasui et al. (1969), Petri e Suguio (1969) e Melcher et al. (1973).

A faixa dobrada que se constituiu, através dos even tos ora reconhecidos, a geocronologia mostra que é atribuí vel a um único ciclo evolutivo; é o Ciclo Brasiliano (A Zme $d a, 1967)$, que teria se desenvolvido num intervalo da ordem de 250 milhões de anos (700-450 m.a.). 
$-180-$

Essa faixa dobrada foi denominada Ribeira por A $m e \underline{i}$ da et al. (no prelo) e se estenderia desde o sul da Bahia até o Uruguai. 
AGRADECIMENTOS

o presente estudo foi realizado com auxílio financei ro da Fundação de Amparo à Pesquisa do Estado de São Paulo (Processo 71/123). A FAPESP concedeu também ao Senhor Dir ceu Abrahão, estudante do Curso de Geologia da Universidade de São Paulo, uma Bolsa de Iniciação Científica, para acompa nhar e auxiliar no desenvolvimento dos trabalhos.

0 Conselho Nacional de Pesquisas houve por bem apoiar - Projeto "Levantamento de Algumas Áreas Pré-Cambrianas do Estado de São Paulo", coordenado pelo Professor Doutor José Moacyr Vianna Coutinho, através de quem contamos com auxílio financeiro parcial para o estudo da Folha de São Roque.

Várias pessoas colaboraram com o Autor sob diferen tes formas. O Professor Doutor Jorge Silva Bettencourt colo o cou à disposição seus estudos inéditos sobre as rochas calcá rias da região de Votorantim e Salto de Pirapora. Os Profes sores Doutor Marcos Aurélio Farias de oliveira e Doutor Ví cente A.V. Girardi auxiliaram-nos no estudo de seções delga das. Ao Professor Doutor Ricardo Francesconi devemos a qua lidade das fotomicrografias. O Professor Doutor Eduardo C. Damasceno e o Engenheiro José do Valle Nogueira Filho gentil mente cederam-nos cópias de plantas geográficas.

- Instituto de Geociências da Universidade de São Paulo, através da Diretoria e da Chefia do Departamento de Geologia Geral, emprestou todo apoio no desenvolvimento des te estudo. As seções de Veículos, de Laminação, de Fotogra fia, de Gráfica e de Desenho do Instituto não mediram esfor ços quando solicitados. O Senhor José Ponchirolli e a senho ra Nair de Campos Louzada pacientemente datilografaram o tex to. 
meida e Doutor Viktor Leinz o Autor deve o estimulo para rea lização desta pesquisa.

A Senhora Sanae Kato Hasui revisou o texto e, duran te o desenvolvimento do estudo, nunca nos faltou com seu apoio e incentivo.

A todas essas entidades e pessoas o Autor consigna sua profunda gratidão. 


\section{B I BLI OGRAFIA}

ALMEIDA,F.F.M.de - 1955 - As camadas de São Paulo e a tectô nica da Serra da Cantareira - Bol.Soc.Bras.Geol.4:23-40. ALMEIDA,F.F.M.de - 1964 - Fundamentos geológicos do relêvo paulista - in Geologia do Estado de São Paulo - Bol.40: 167-274, Inst.Geogr.Geol. Est.São Paulo.

ALMEIDA,F.F.M.de - 1967 - Origem e evolução da Plataforma Brasileira - Bol.24l, Div.Geol.Min., Depto.Nac. Prod. Min.

ALMEIDA,F.F.M.de - 1968 - Evolução tectônica do Centro-0este Brasileiro no Proterozóico Superior - An. Acad. Bras. Ciênc., 40 (suplemento): 285-295.

ALMEIDA,F.F.M.de - 1969 - Diferenciação tectônica da Plataforma Brasileira - Anais XXIII Congr.Bras.Geol. 23-46. Soc.Bras.Geol.

ALMEIDA, F.F.M.de, AMARAL, G., CORDANI,U.G. e KAWASHITA,K. The precambrian evolution of the South-American cratonic margin, south of the Amazon River. No prezo. AMARAL, G., BUSHEE, J., CORDANI,U.G., KAWASHITA,K. e REYNOLDS, J.H. - 1967 - Potassium-argon ages of alkaline rocks from Southern Brazil - Geoch.Cosm.Acta 31:117-142.

AMARAL,G., CORDANI,U.G., KAWASHITA,K. e REYNOLDS,J.H.-1966Potassium-argon dates of basaltic rocks from Southern Brazil - Geoch.Cosm.Acta 30:159-189.

AMARAL,S.E. - 1971 - Geologia e petrologia da Formação Irati (Permiano) no Estado de São Paulo - Bol.IGA 2: 5-81, Inst.Geoc. Univ.são Paulo.

AMERICAN COMMISSION ON STRATIGRAPHIC NOMENCLATURE - 1961 -

Code of Stratigraphic Nomenclature - Bull. Am. Ass. of Petr.Geol. 45(5):645-665.

AUBOIN,J. - 1965 - Geosynclines - Developments in Geotectonics I - Elsevier Publ. Co. BADGLEY,P.C. - 1965 - Structural and tectonic principles Harper and Row. 
BELOUSSOV, V.V. - 1962 - Basic problems in Geotectonics McGraw-Hill Book Co.

BETTENCOURT,J.S. - 1971 - Os depósitos de rochas calcärias das regiões de Santa Helena e Santa Maria (Municípios de Votorantim e Brigadeiro Tobias) - Mimeografado.

BETTENCOURT,J.S., FULFARO,V.J., GIRARDI,V.A.V. e PETRI,S. 1971 - Geologia da Folha de Capão Bonito, SP - Anais XXV Congr.Bras.Geol. 1:97. Soc.Bras.Geol.

BIGARELLA, J.J., SALAMUNI,R. - 1956 - Estudos preliminares na Série Açungui. V - Estruturas organógenas nos dolomitos da Formação Capiru, Estado do Paraná - Dusenia VII (6): 317-333, Curitiba.

BIGARELLA,J.J., SALAMUNI, R. - 1958 - Estudos preliminares na Série Açungui. VIII - A Formação Votuverava - Bol. Inst. Hist.Nat., Geol. 2, Curitiba.

BILLINGS,M.P. - 1954 - Structural Geology - 2a ed. PrenticeHall Inc.

BOUMA.A.H. - 1962 - Sedimentology of some flysch deposits. A graphic approach to facies interpretation - Elsevier Publ. Co.

CARVALHO,P.F., PINTO,E.A. - 1937 - Reconhecimento geológico na Série Açungui - Bol.7l, Ser.Geol.Min.do Brasil.

CHAYES,F. - 1949 - A simple point counter for thin-section analysis - Am.Min. 34:1-11.

CORDANI,U.G. e BITTENCOURT,I. - 1967 - Determinações de idade potássio-argônio em rochas do Grupo Açungui - Anais XXI Congr.Bras.Geol., 218-233. Soc.Bras.Geol.

CORDANI,U.G., BITTENCOURT,I., BETTENCOURT,J.S., GOMES, C.B., LELLIS,H.S., MELCHER,G.C. e MELFI,A.J. - 1971 - Geologia da Folha de Guapiara, SP - Anais XXV Congr. Bras. Geol.. 1:95. Soc.Bras.Geol.

CORDANI,U.G., GIRARDI,V.A.V., GOMES,C.B., MELFI,A.J.e MELCHER,G.C. - 1971 a - Geologia da Folha de Eldorado, SP. Anais XXV Congr.Bras.Geol. 1:103, Soc.Bras.Geol. 
CORDANI,U.G., GOMES,C.B. e GIRARDI,V.A.V. - 1963 - Rochas cálcio-silicatadas da região de Perus, SP - Anais Acad. Bras. Ciênc. 35:361-372.

CORDANI,U.G. e KAWASHITA,K. - 1971 - Estudo geocronológico pelo método Rb-Sr, de rochas graníticas intrusivas no Grupo Açungui - Anais XXV Congr.Bras.Geol. 1:105-110. Soc.Bras.Geol.

COUTINHO,J.M.V. - 1953 - Petrologia da região de São Roque - Bol.159. Min.ll, Fac.Fil.Ciên. e Letr., Univ. São Pau 10 .

COUTINHO,J.M.V. - 1972 - Petrologia do Pré-Cambriano em São Paulo e arredores - Bol. IGA 3: 5-99, Inst.Geoc., Univ. São Paulo.

CRADDOCK,J.C. - 1957 - Stratigraphy and structure of the Kinderhook Quadrangle, New York, and the "Taconic Klippe" - Bull.Geol.Soc.Am. 68:675-723. DONATH,F.A. e PARKER,R.B. - 1964 - Folds and folding -Bull. Geol.Soc.Am. 75:45-62. DZULYNSKI,S., e WALTON,E.K. - 1965 - Sedimentary features of flysch and greywacks - Developments in Sedimentology, $n^{8} 7$ - Elsevier Publ. Co.

EBERT,H. - 1971 - Observações sôbre a litologia e subdivisão do "Grupo Setuva" no Estado do Paraná; com sugestões à tectônica geral do "Geossinclínio Açungui"-Anais XXV Congr. Bras.Geol. 1:131-165. Soc.Bras.Geol.

ELLERT,R. - 1961 - Contribuição à geologia do Pré-Cambriano na região de São Bernardo do Campo, SP - Bol. Soc.Bras. Geol. 10:49-56.

FELICISSIMO JR., J. - 1968 - Carbonatitos do Estado de São Paulo - Anais Acad.Bras.Ciênc. 40(suplemento):93-115. FLORENCE,G. - 1907 - Notas geológicas sobre o Rio Tietê em - trecho estudado pela turma em 1905 - in ExpZoracão do Rio Tietê, Comm.Geogr. e Geol. Prov.de S.Paulo.p.9-15. FRANCO,R.R. - 1956 - Migmatitos de textura gnáissica dos ar redores de São Paulo - Bol.Soc.Bras.Geol.5:31-60. 
FRANCO,R.R. - 1958 - Contribuição ao conhecimento de rochas termometamórficas da Série São Roque - Bol.189, Min.14. Fac.Fil.Ciênc.e Letr., Univ. São Paulo.

FREITAS,R.O. - 1951 - Sôbre a origem da Bacia de São Paulo - Bol.Paul.Geogr. 9:60-64.

FUCK,R.A., MARINI,O.J., TREIN,E. e MURATORI,A. - 1971 - Geo logia do Leste Paranaense - Anais XXV Congr. Bras.Geol. $1: 121-130$.

FUCK,R.A., TREIN,E. e MARINI,O.J. - 1967 - Geologia e petro grafia dos migmatitos do Paraná - Bol.Paran.Geoc.l23 a $25): 5-41$.

GNIBIDENKO,H.S. e SHASHKIN,K.S. - 1970 - Basic principles of Geosynclinal theory - Tectonophysics 9:5-13. GOMES,C.B., BITTENCOURT,I., CORDANI,U.G., DAMASCENO,E.C., LELLIS,H.S., MELCHER,G.C. e MELFI,A.J. - 1971 - Geologia da Folha de Cerro Azul, SP e PR - Anais XXV Congr. Bras.Geol. 1:99, Soc.Bras.Geol. GOMES,C.B., BITTENCOURT,I., CORDANI,U.G., FULFARO, V.J., MELFI,A.J. e PETRI,S. - $1971 a$ - Geologia da Folha de Itararé, SP e PR - Anais XXV Congr.Bras.Geol.1:93.Soc. Bras.Geol.

GUIMARAES,D. - 1964 - Geologia do Brasil - Mem.1, Div.Geol. Min.. Depto.Nac.Prod.Min.

HASUI, Y. e HAMA,M. - 1972 - Geocronologia do Grupo São Roque pelo método potássio-argônio - Rev.Bras.Geoc.2:1824.

HASUI, Y. PENALVA,F. e HENNIES,W.T. - 1969 - Geologia do Grupo São Roque - Anais XXIII Congr.Bras.Geol.,101-134. HEINRICH,E.W. - 1956 - Microscopic petrography - McGrawHill Book Co. HENNIES,W.T. ; HASUI,Y. e PENALVA,F. - 1967 - 0 Falhamento transcorrente de Taxaquara - Anais XXI Congr.Bras.Geol. p. $159-168$.

HERMES,J.J. - 1968 - The Papuan geosyncline and the concept of geosynclines - Geol.Mijnb.47:81-97. 
HILLS,E.S. - 1963 - Elements of Structural Geology - John Wiley and Sons Inc.

INSTITUTO GEOGRÄFICO E GEOLOGICO DO ESTADO DE SÃO PAULO -

1963 - Mapa Geológico do Estado de São Paulo.1:1.000.000. JUNG,J. e ROQUES,M. - 1952 - Introduction à l'étude zonéo-

graphique des formations cristallophyllienes - Bull.serv.

Carte Géol.France 50.

KAY, M. - 1947 - Geosynclinal nomenclature and the craton

Bull.Am.Ass.Petr.Geol. 31:1289-1293.

KHAIN, V.E. e MURATOV,M.V. - 1968 - Geosynclinal belts, oroge nic belts, folded belts and their relation in time and space - XXIII Congr.Int.Geol.(Praga),3:9-13.

KNECHT,T. - 1960 - Notas preliminares sôbre novas ocorrências de rochas alcalinas no Estado de São Paulo - Bol. Soc.Bras.Geol.9(1):71-76.

KNOPF,E.B. - 1931 - Retrogressive metamorphism and phyllonitization - Am.J.Sci. 21:1-27 (5a Série).

KOLLERT, R. e DAVINO,A. - 1963 - Levantamento gravimétrico na Bacia de São Paulo - Eng.Min.Met. 38:79-82. LEINZ,V. e CARVALHO,A.M.V.de - 1957 - Contribuição à Geologia da Bacia de São Paulo - Bol.205, Geol.15, Fac. Fil.

Ciênc. e Letr. Univ. São Paulo. MARINI,O.J., TREIN,E. e FUCK,R.A. - 1967 - O Grupo Açungui no Estado do Paraná - Bol.Paran.Geoc. (23 a 25): 43-103. MARMO, V. - 1971 - Granite petrology and the granite problemElsevier Publ. Co.

MEAD,W.J. - 1940 - Folding, rock flowage, and foliate structures - J.Geol. 48:1007-1021.

MEHNERT,K.R. - 1968 - Migmatites and the origin of granitic rocks - Elsevier Publ. Co.

MELCHER, G.C., CORDANI,U.G., DAMASCENO,E.C., GIRARDI, V. A.V., GOMES,C.B., LELLIS,H.S. e MELFI,A.J. - 1971 - Geologia da Folha de Apiai, SP e PR - Anais XXV Congr.Bras. Geol. 1:101, Soc.Bras.Geol. 
MELCHER, G.C., GOMES, C.B., CORDANI,U.G., BETTENCOURT, J. S., DAMASCENO,E.C., GIRARDI,V.A.V. e MELFI,J.A. - 1973 Geologia e Petrologia das rochas metamórficas e graniticas associadas do Vale do Rio Ribeira de Iguape,SP e PR -Rev.Bras.Geoc. (no prezo).

MELFI,A.J., BITTENCOURT,I. e CORDANI,U.G. - 1965 - Reconheci mento fotogeológico de parte do Grupo Açungui - Bragantia 24:447-474, Campinas.

MENDES,J.C. - 1950 - 0 problema da idade das camadas de São Paulo - Bol.Paul.Geogr. 5:45-48.

MIKHAYLOV,A.Y. - 1970 - The development of geosynclines and folding - Int.Geol.Rev.12:1490-1495.

MIYASHTRO,A. - 1961 - Evolution of metamorphic belts - J.Petrol. $2: 277-311$.

MOODY,J.D. e HILL,M.J. - 1956 - Wrench-fault tectonics Bull.Geol.Soc.Am. 67:1207-1248.

MORAES REGO,L.F.de - 1933 - Contribuição ao estudo das forma ções pre-devoneanas de São Paulo- Inst.Astron.e Geof. de São Paulo.

MORAES REGO,L.F.de e SOUZA SANTOS,T.D. - 1938 - Contribuição para o estudo dos granitos da Serra da Cantareira - Bol. 18. Inst. Pesq. Tecn. de São Paulo.

MURATOV,M.V. - 1968 - Geosynclinal folded belts and systems - stages of development and igneous activity - Int.Geol. Rev. 10:1386-1402.

OLIVEIRA,A.I. e LEONARDOS,O.H. - 1943 - Geologia do Brasil

- Ser.Did.2 - Serv.Inf.Agricola, Min.da Agric., Brasil. OLIVEIRA,E.P. - 1925 - Mapa Geológico do Estado do Paraná, 1:1.000.000 - Serv.Geol.Min.do Brasil.

OLIVEIRA,E.P. - 1927 - Geologia e recursos minerais do Esta do do Paraná - Mon. 6 Serv.Geol.Min. do Brasil.

PENALVA, F. e HASUI,Y. - 1970 - A intrusão granítica dos Mor ros Grande e Tico-Tico, Município de Caieras, SP - An. Acad.Bras. Ciênc. 42:725-730. 
PETRI,S. e SUGUIO,K. - 1969 - Sôbre os metassedimentos do Grupo Açungui no extremo Sul do Estado de São Paulo

Publ. 2, Serv. Vale do Ribeira, Depto.Aguas e Energia Elëtrica, Secr.Serv. e Obras do Estado de São Paulo. RAGUIN,E. - 1965 - Geology of granite - Interscience Publ. RAMSAY,J.G. - $196 ?$ - Folding and fracturing of rocks

McGraw-Hill Book Co. RAST,N. - 1958 - Tectonics of the Schichallion Complex Q.J.Geol.Soc.Lond. 114:25-46. READ,H.H. - 1957 - The granite controversy - Murby. ROBERTS,J.L. e TREAGUS,J.E. - 1964 - A re-interpretation of the Ben-Lui fold - Geol.Mag. 101:512-516.

ROCHA-CAMPOS,A.C. - 1967 - The Tubarão Group in the Brazilian portion of the Paraná Basin - in J.J.BigareZZa,R.D. Becker, I.D.Pinto (eds). Problems in Brazilian Gondwana Geology. I Intern.Symp. on the Gondwana Stratigr. and Paleont. p.28-102.

SITTER,L.U.de - 1964 - Structural Geology - 2a ed - McGraw$\mathrm{Hill}$ Book Co.

SUTTON,J. e WATSON,J. - 1959 - Structures in the Caledonides between Loch Duich and Glenelg. Northwest Highlands Q.J.Geol.Soc.Lond. 114:231-257 (for 1958). TURNER,F.J. - 1968 - Metamorphic petrology mineralogical and field aspects - McGraw-Hill Book Co. TURNER,F.J. e VERHOOGEN,J. - 1960 - Igneous and metamorphic petrology - 2a ed. - McGraw-Hill Book Co. TURNER,F.J.e WEISS,L.E. - 1963 - Structural analysis of metamorphic tectonites - McGraw-Hill Book Co. USTIYEV,E.K. - 1970 - Relations between volcanism and pluto nism at different stages of the tectonomagmatic cycle.in G.NewaZl-N.Rast (eds), Mechanism of igneous intrusion - Geol.J.Sp. Issue $n^{2} 2, \mathrm{p} .1-22$. WEISS,J. - 1949 - Wissahickon schist at Philadelphia, Pennsylvania - Bull. Geol.Soc.Am. 60:1689-1726. 
WHITTEN,E.H.T. - 1959 - A study of two directions of folding: the structural geology of the Monadhliath and Mid-strath pey - J.Geol. 67:14-47.

WHITTEN,E.H.T. - 1966 - Structural geology of folded rocks Rand McNally and Co.

WILLIAMS,H., TURNER,F.J.e GILBERT,C.M. - 1954 - Petrography

- W.H. Freeman and Co.

WINKLER,H.G.F. - 1967 - Petrogenesis of metamorphic rocks 2 a ed., rev. - Springer-Verlag.

ZWART,H.J. - 1963 - Some examples of the relations between deformation and metamorphism from Central Pyrenees Geol.Minjb. 42:143-154.

ZWART,H.J. - 1967 - The duality of orogenic belts - Geol. Minjb. 46:283-309. 

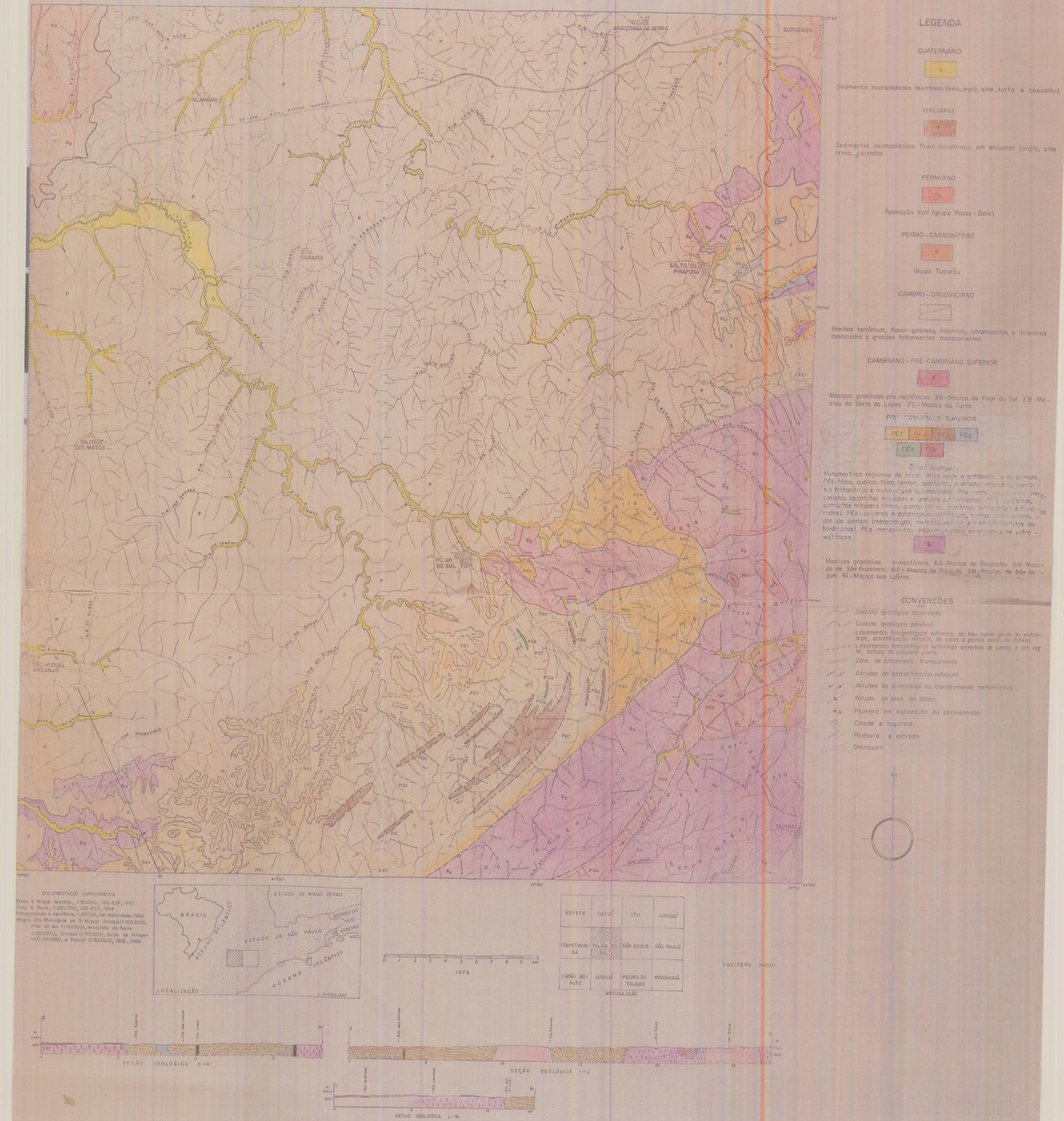
SÃO ROQUE

FOLHA $S F, 23-Y-C-\mathrm{V}$

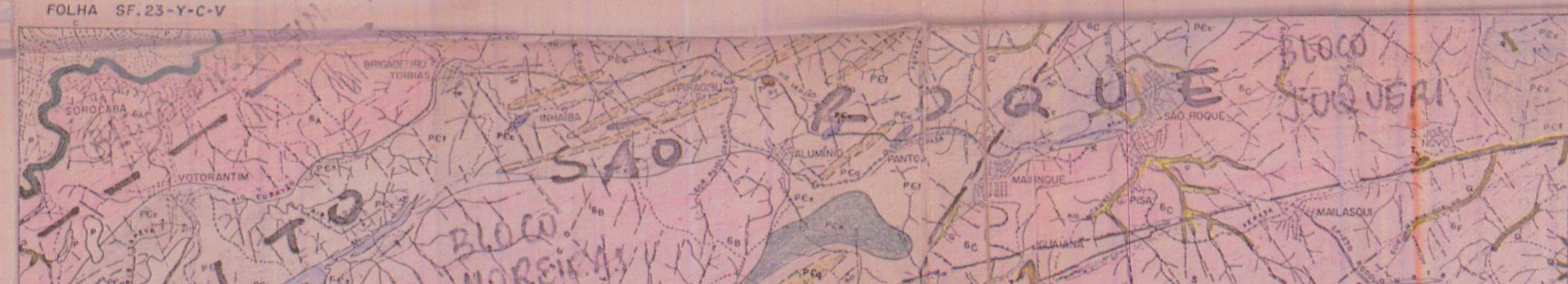

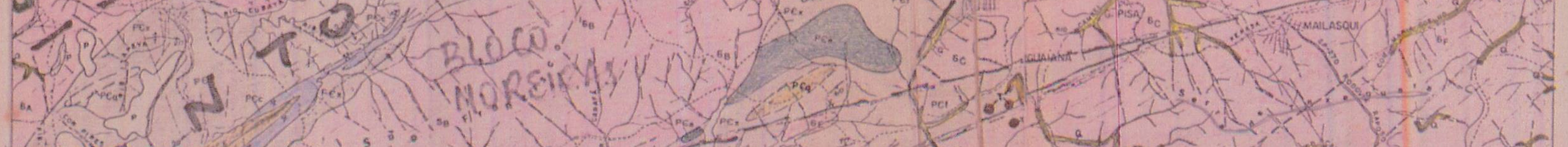

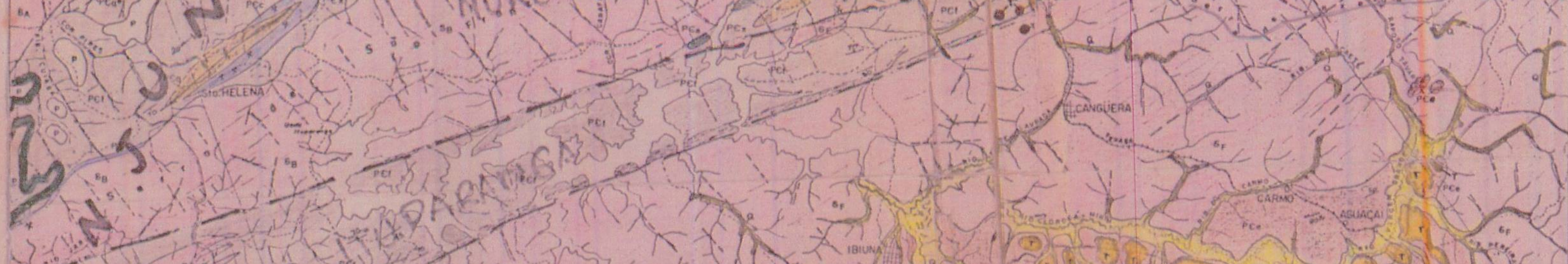

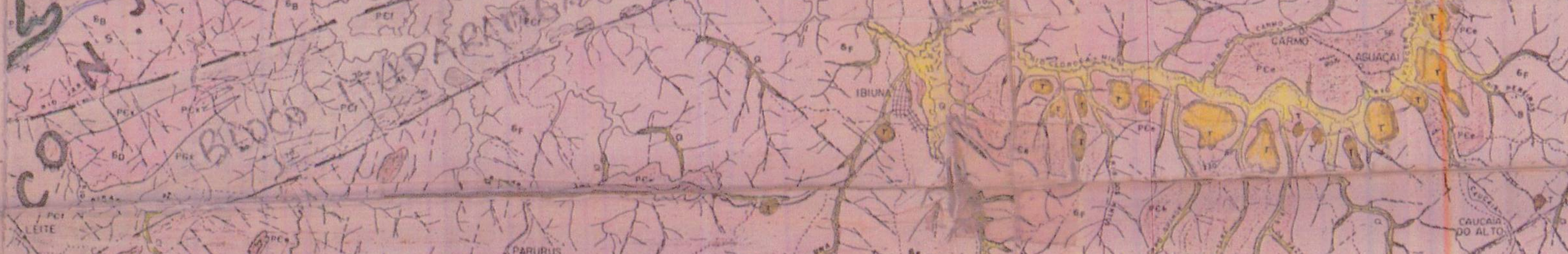

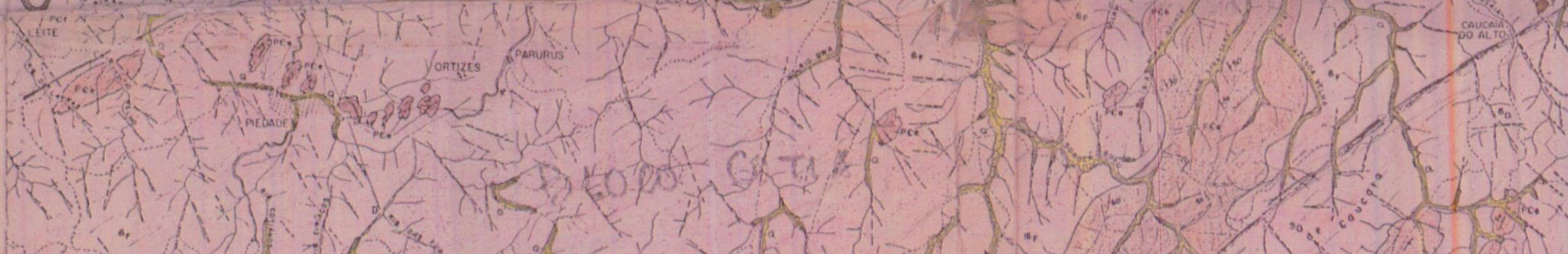

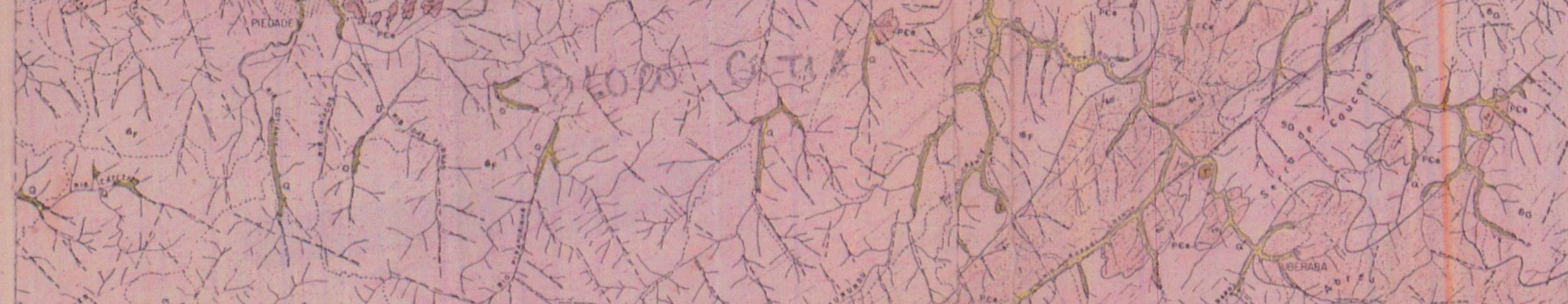

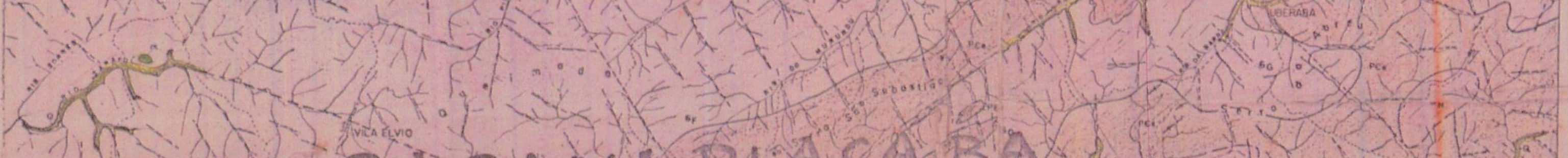
I UNTO PARANA PINCABA J J JIE

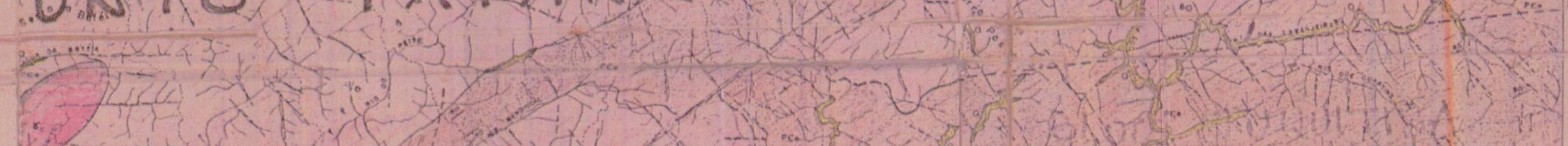

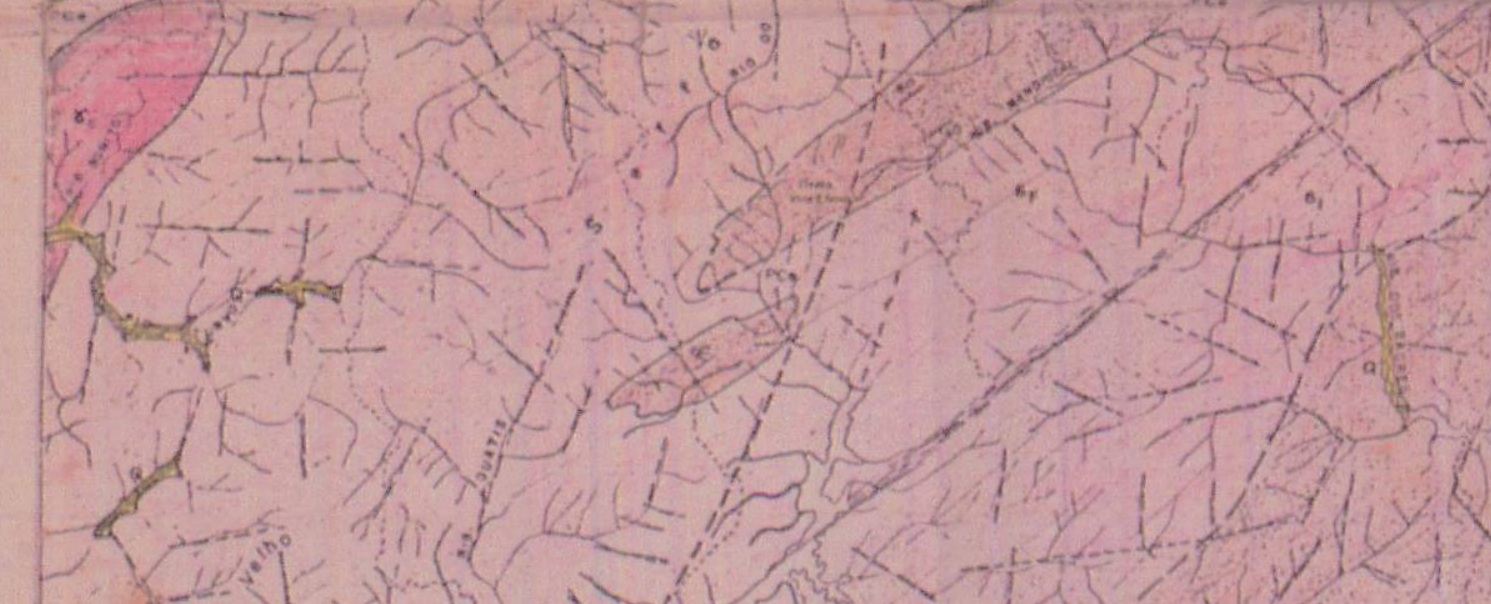

(1) $-2,+2$

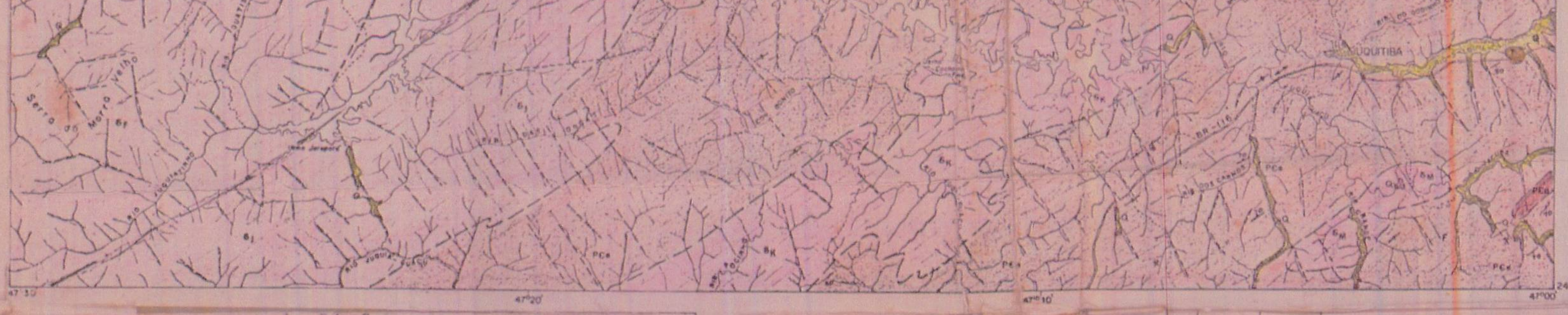

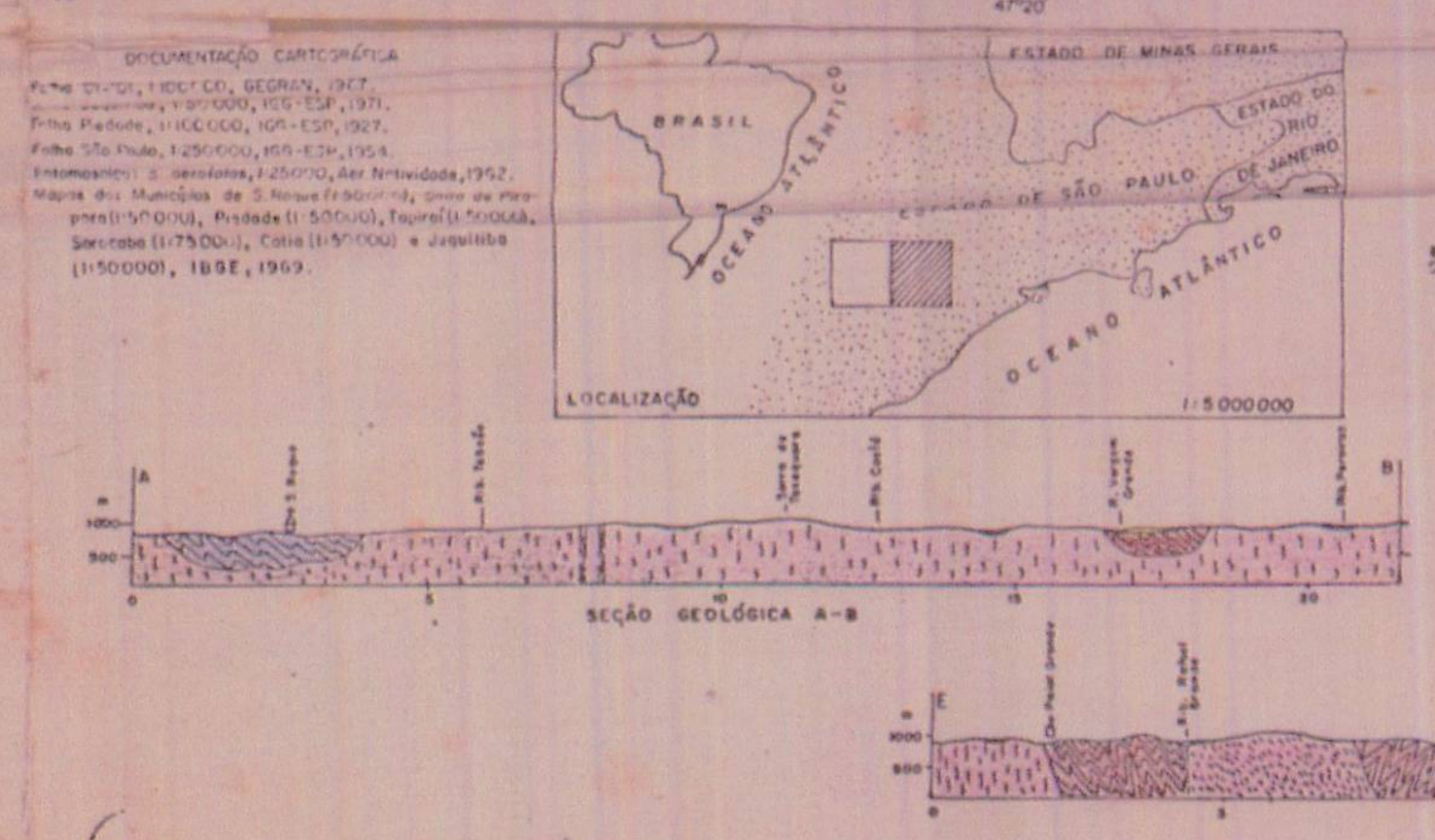
2.

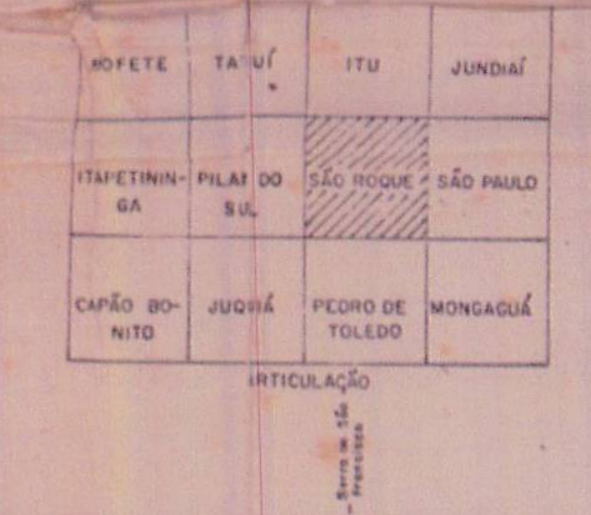
$4 \quad L=\frac{1}{1}=$

CAMBRIANO-PRÉ-CAMBRIANO SUPERIOR [ Mocicos proniticos pós- - tectroncos $\gamma c$ - Mocico do Turno PRÉ-CAMBRIANO SUPERIOR

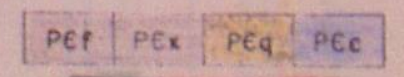
Pra pee PEo Pa

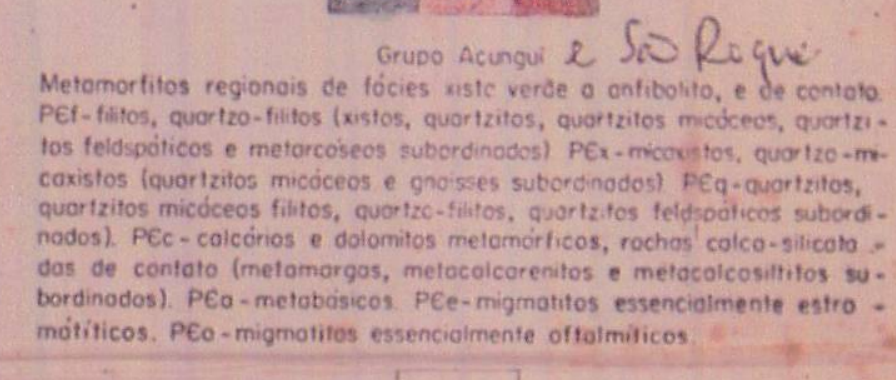

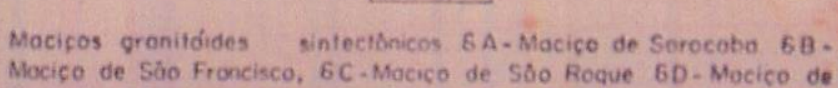

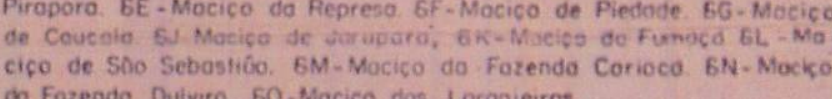
convencoss

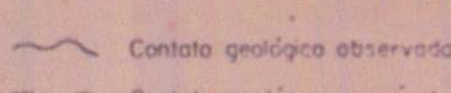

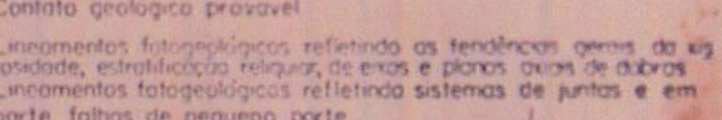
porte, tolthos de pequeno porte

- At Atudes do estrotificocóo reliquior

If. Atitudes de eixos de dobros

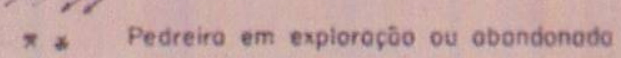

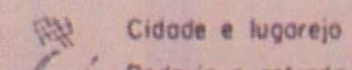

$<$ orenogem 